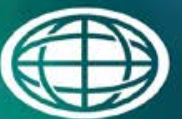

Savannah River

National Laboratory ${ }^{m}$

OPERATED BY SAVANNAH RIVER NUCLEAR SOLUTIONS

\title{
Impact of Scaling on the Nitric-Glycolic Acid Flowsheet
}

D.P. Lambert

J.R. Zamecnik

J.D. Newell

C.J. Martino

February 2016

SRNL-STI-2014-00306, Revision 0 


\section{DISCLAIMER}

This work was prepared under an agreement with and funded by the U.S. Government. Neither the U.S. Government or its employees, nor any of its contractors, subcontractors or their employees, makes any express or implied:

1. warranty or assumes any legal liability for the accuracy, completeness, or for the use or results of such use of any information, product, or process disclosed; or

2. representation that such use or results of such use would not infringe privately owned rights; or

3. endorsement or recommendation of any specifically identified commercial product, process, or service.

Any views and opinions of authors expressed in this work do not necessarily state or reflect those of the United States Government, or its contractors, or subcontractors.

\section{Printed in the United States of America \\ Prepared for U.S. Department of Energy}


SRNL-STI-2014-00306

Revision 0

Keywords: Alternate reductant, DWPF

Retention: Permanent

\section{Impact of Scaling on the Nitric-Glycolic Acid Flowsheet}

D.P. Lambert

J.R. Zamecnik

J.D. Newell

C.J. Martino

February 2016

Prepared for the U.S. Department of Energy under 


\section{REVIEWS AND APPROVALS}

\section{AUTHORS:}

D.P. Lambert, Process Technology Programs

Date

J.R. Zamecnik, Process Technology Programs

Date

J.D. Newell, Process Technology Programs

Date

C.J. Martino, Process Technology Programs

Date

TECHNICAL REVIEW:

J.M. Pareizs, Process Technology Programs, Reviewed per E7 2.60

Date

APPROVAL:

F.M. Pennebaker, Manager

Date

Process Technology Programs

D.E. Dooley, Director, Environmental \& Chemical Process Technology Research Programs

Date

E.J. Freed, Manager

Date

DWPF and Saltstone Facility Engineering 


\section{ACKNOWLEDGEMENTS}

The ten runs, including testing at three different scales, were completed between May 20 and October 9, 2014. The equipment for the 220-L rig was all new and required fabrication, installation, startup testing and the actual experiments. This work took a large team to accomplish. The following people and groups listed below were instrumental in completing this testing:

Thanks to the technicians responsible for the testing: Jon Duvall, Vickie Williams, Phyllis Workman, David Healy, Kim Wyszynski, Wanda Matthews, and Andy Foreman. The technicians worked twelvehour day or night shifts for seven weeks. The experiments were long and complicated, with hundreds of samples.

Thanks to Frances Williams, John Pareizs, Matt Williams, and Jack Zamecnik for moving, setting up, calibrating and running the GC, MS and FTIR offgas instruments that collected so much data during these runs. Thanks also to John Pareizs, Matt Williams, and Jack Zamecnik for collecting and analyzed the offgas data and completing the mass balances needed for understanding not just the peak concentrations but also the totalized mass.

Thanks to Mark Jones for his support in designing the 220-L rig. Thanks to Gary Dobos and Curt Sexton for their support in fabricating the glassware, especially the new SRAT vessel for the 22-L scale and the condensers, scrubbers, etc. for the 220-L rig. Thanks to Bill Price for developing the pressure safety documentation for the steam generator. Thanks to Joel Jones and Kenn Gibbs for developing the LabVIEW automation and control software for the 220-L rig. Thanks to Frances Williams for her support for the procurement of the equipment to support the 220-L testing.

Thanks to Kim Wyszynski, Beverly Wall, Whitney Riley, and David Best for analyzing nearly onethousand samples to support this testing. Each of these samples had multiple analytes and/or repeat analyses, not to mention all the dilutions, standards, and blanks that had to be prepared and analyzed.

Thanks to Holly Hall for coordinating all of the samples including preparing/labeling the sample bottles, preparing the sample request forms, and arranging delivery of all the samples.

Thanks to Tom White and Chuck Coleman for their work in developing an improved method of glycolate analysis. Thanks to Tom for analyzing and reanalyzing so many SRAT and SME products from these runs for anions and ammonium. 
SRNL-STI-2014-00306

Revision 0

\section{EXECUTIVE SUMMARY}

Savannah River Remediation (SRR) is considering using glycolic acid as a replacement for formic acid in Sludge Receipt and Adjustment Tank (SRAT) processing in the Defense Waste Processing Facility (DWPF). Catalytic decomposition of formic acid is responsible for the generation of hydrogen, a potentially flammable gas, during processing. To prevent the formation of a flammable mixture in the offgas, an air purge is used to dilute the hydrogen concentration below the $60 \%$ of the Composite Lower Flammability Limit (CLFL). The offgas is continuously monitored for hydrogen using Gas Chromatographs (GCs). Since formic acid is much more volatile and toxic than glycolic acid, a formic acid spill would lead to the release of much larger quantities to the environment. Switching from formic acid to glycolic acid is expected to eliminate the hydrogen flammability hazard leading to lower air purges, thus downgrading of Safety Significant GCs to Process Support GCs, and minimizing the consequence of a glycolic acid tank leak in DWPF. Overall this leads to a reduction in process operation costs and an increase in safety margin.

Experiments were completed at three different scales to demonstrate that the nitric-glycolic acid flowsheet scales from the 4-L lab scale to the 22-L bench scale and 220-L engineering scale. Ten process demonstrations of the sludge-only flowsheet for SRAT and Slurry Mix Evaporator (SME) cycles were performed using Sludge Batch 8 (SB8)-Tank 40 simulant. No Actinide Removal Process (ARP) product or strip effluent was added during the runs. Six experiments were completed at the 4-L scale, two experiments were completed at the 22-L scale, and two experiments were completed at the 220-L scale. Experiments completed at the 4-L scale (100 and 110\% acid stoichiometry) were repeated at the 22-L and 220-L scale for scale comparisons.

The main differences between the runs were scale, acid stoichiometry and the ratio of total acid to glycolic acid. The primary objective of the testing was to determine whether important processing parameters are impacted by the scale of the experiment. The three experimental scales utilized are consistent with scaled testing that increases in scale by a factor of ten with each larger scale. The scale that is missing is a semiworks scale such as was used in the DWPF pilot plants. However, testing at that scale is prohibitively expensive and would only be needed if the testing completed to date did not scale. For the nitric-glycolic acid flowsheet, semiworks testing is not warranted based on this study.

\section{SRAT and SME testing}

Six of the ten runs (two at each scale) are summarized in the table below. As has been noted for the nitricformic acid flowsheet, the chemistry scales well. In all runs the hydrogen generation was low and the SRAT cycle mercury reduction and recovery were acceptable. A number of parameters were monitored including the fate of antifoam and the carbon and nitrogen balances needed for predicting glass REDuction/OXidation (REDOX).

The majority of the chemistry occurs during acid addition and the dewater phase of the SRAT cycle. Because of the length of the SME cycle, some chemistry takes place in the SME, which is important for predicting glass REDOX. The melter feed waste loading, solids content, and the antifoam degradation products were also measured. 
Overall Summary of Scaled Experiments

\begin{tabular}{|l|l|l|l|l|l|l|l|}
\hline \multicolumn{1}{|c|}{ Acid Stoichiometry } & \multicolumn{3}{c|}{$100 \%$} & & \multicolumn{3}{c|}{$110 \%$} \\
\hline Run & GN74 & GN76 & GN79 & & GN73 & GN77 & GN78 \\
\hline SRAT Scale & $1 / 7,541$ & $1 / 1,317$ & $1 / 170$ & & $1 / 7,541$ & $1 / 1,443$ & $1 / 199$ \\
\hline SME Scale & $1 / 9,504$ & $1 / 1,690$ & $1 / 187$ & & $1 / 9,504$ & $1 / 1,783$ & $1 / 222$ \\
\hline Process Chemistry & & & & & & & \\
\hline Hydrogen & & & & & & & \\
\hline Hg Reduction/Collection & & & & & & & \\
\hline Glass REDOX & & & & & & & \\
\hline
\end{tabular}

\begin{tabular}{|l|l|}
\hline & Excellent \\
\hline & Good \\
\hline & Unacceptable \\
\hline
\end{tabular}

The chemistry and processing were virtually identical at the three scales tested. There were a few areas where a parameter did change with scale (such as nitrite to nitrate conversion and mercury collection), but nitrite to nitrate conversion is sensitive to internal reflux, it was expected to change with scale. Two potential flammability hazards, namely hydrogen and ammonia generation, have been reduced by more than a factor of ten by replacing formic acid with glycolic acid, and this was not impacted by the testing scale.

Some highlights from the experiments include:

- The experimental work was completed without significant process deviations or process upsets. The experiments were completed as directed by the principal investigator meaning the planned mass for sludge, acids, SRAT dewater, canister decontamination water addition and dewater, and process frit addition and dewater met planned targets as did the addition rates for the reagents and the time at temperature for the experiments.

- More than 800 liquid samples were pulled and several-hundred-thousand offgas samples from three offgas analyzers (gas chromatograph, mass spectrometer, and Fourier transform infrared) were collected and tracked throughout the experiments for an improved understanding of the process chemistry.

- Very low hydrogen generation (about 1\% of current limit) was experienced at all scales (except in Run GN71 during rod fouling where the surface temperature of the rod significantly exceeded the maximum possible steam coil temperature). The upper $95 \%$ confidence bound on the GC peak SRAT hydrogen generation rate was $6.6 \mathrm{E}-3 \mathrm{lb} / \mathrm{hr}$ DWPF Scale in run GN70. The upper 95\% confidence bound on the GC peak SME hydrogen generation rate was 8.7E-3 lb/hr DWPF Scale in run GN79.

- A lower SRAT air purge (230 standard cubic feet per minute, scfm for nitric-formic acid flowsheet, $94 \mathrm{scfm}$ for nitric-glycolic acid flowsheet) was used due to the extremely low hydrogen generation rates to both demonstrate reduced purge rates and improve hydrogen detection.

- The sample and offgas data were used to complete mass balances for the reactive species during SRAT and SME processing. These mass balances for carbon and nitrogen species demonstrated that the process chemistry was equivalent at all three scales tested.

- The ammonia generation was very low (at or near detection limits).

- The SRAT and SME product pHs are stable and significantly lower than comparable nitricformic acid flowsheet operations.

- The mercury collection in the Mercury Water Wash Tank (MWWT) was slightly higher than is seen in nitric-formic flowsheet runs. Mercury recovery in the MWWT averaged 19\% in the 100\% 
Koopman Minimum Acid stoichiometry (KMA) runs and 43\% in the 110\% KMA runs. The higher acid stoichiometry runs had higher mercury collection than the lower acid stoichiometry runs without increased hydrogen generation.

- The measured REDOX for glass produced from SME products using the closed crucible hot method varied from 0.03 to $0.30 \mathrm{Fe}^{2+} / \Sigma \mathrm{Fe}$. The REDOX for the duplicated runs targeted 0.20 $\mathrm{Fe}^{2+} / \Sigma \mathrm{Fe}$ and averaged $0.15 \mathrm{Fe}^{2+} / \Sigma \mathrm{Fe}$.

- Nitrite and carbonate in the sludge was completely destroyed during SRAT processing. Nitrite to nitrate conversion averaged $35 \%$ in the $100 \%$ KMA runs and $50 \%$ in the $110 \%$ KMA runs. Nitrite reacts to form $\mathrm{NO}, \mathrm{N}_{2} \mathrm{O}$, and $\mathrm{NO}_{2}$, but very little ammonia. Some oxalate and formate are produced during SRAT processing.

- No foamovers were noted during processing. There were small carryover events of entrained slurry in runs GN70, GN73, and GN76. The antifoam strategy used in these runs was effective in controlling foam at all scales. The antifoam did degrade over time based on offgas and slurry analyses, as it does in the nitric-formic acid flowsheet. No difference in antifoam degradation is seen compared to nitric-formic acid flowsheet experiments.

\section{Recommendations Prior to Implementation of the Nitric-Glycolic Flowsheet in DWPF}

Based on the scaled testing completed, the nitric-glycolic acid flowsheet is recommended for implementation in DWPF Chemical Process Cell (CPC) because of the successful testing that has been completed to date.

The following is recommended:

1. Re-evaluate the REDOX data if a new REDOX method or REDOX equation is developed for the nitric-glycolic acid flowsheet. This report should be revised to update the predictions based on the best REDOX equation.

2. Re-evaluate the acid stoichiometry calculation when a revised acid stoichiometry equation has been developed for the nitric-glycolic acid flowsheet. This report should be revised to update the predictions based on the best acid stoichiometry equation.

3. The complete discussion of chemistry was not part of this study but the data generated here will be included in the chemistry analysis. A report that brings together all of the chemistry data to date will be issued. It is recommended that analysis of the following data would be useful for better understanding the DWPF processing using the nitric-glycolic acid flowsheet. 


\section{TABLE OF CONTENTS}

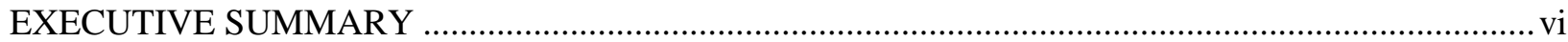

Recommendations Prior to Implementation of the Nitric-Glycolic Flowsheet in DWPF.....................viii

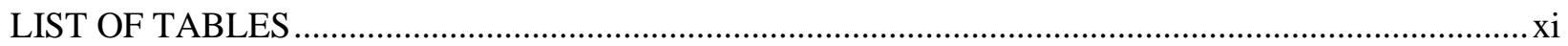

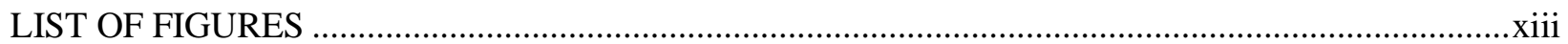

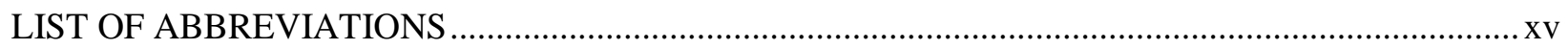

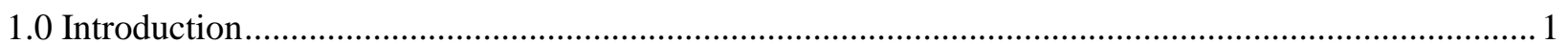

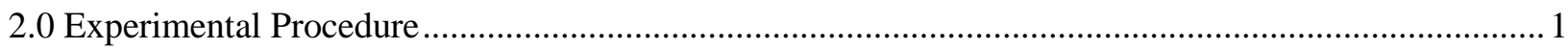

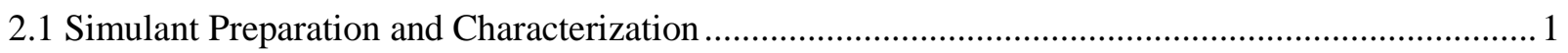

2.2 Chemical Process Cell Equipment and Testing........................................................................... 3

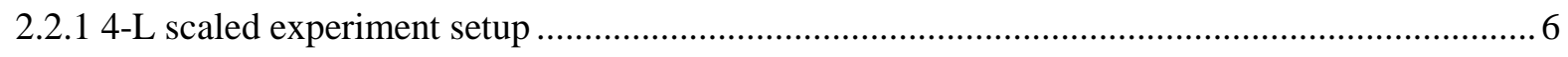

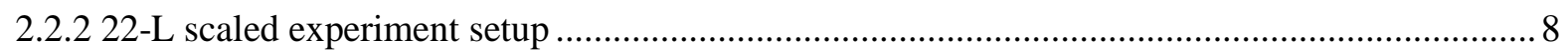

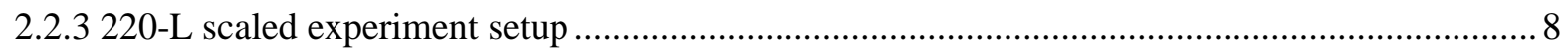

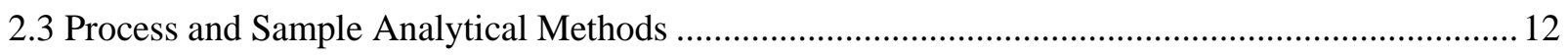

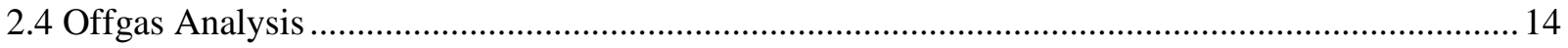

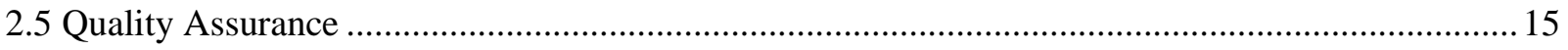

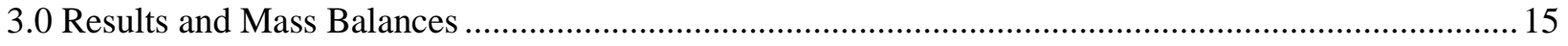

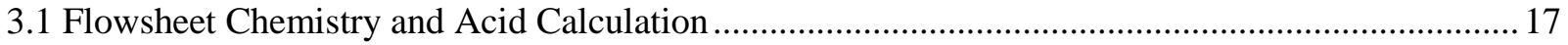

3.2 Overall Mass Balance and Process Times......................................................................................... 17

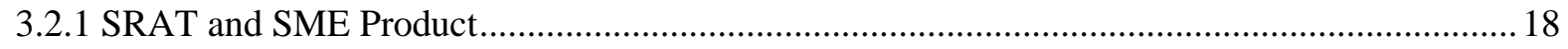

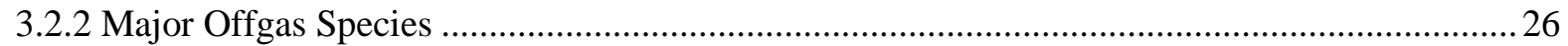

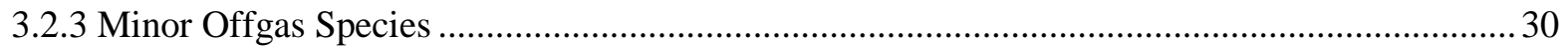

3.2.4 Nitrogen Chemistry Balance...................................................................................................... 33

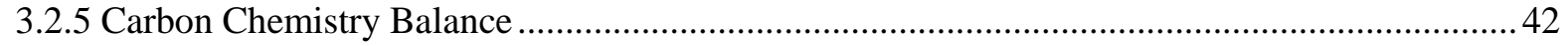

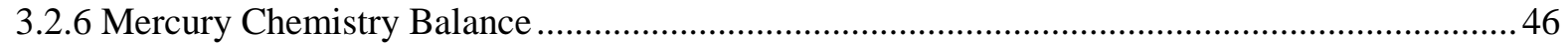

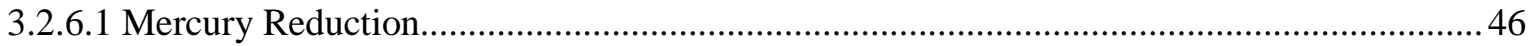

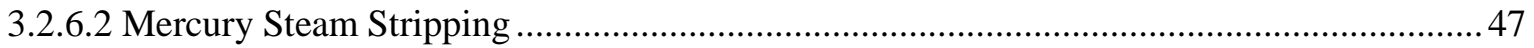

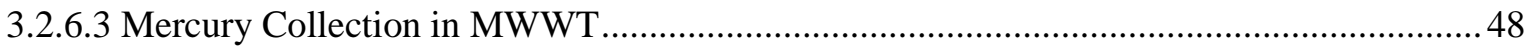

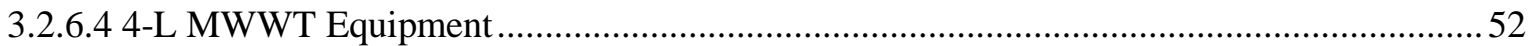

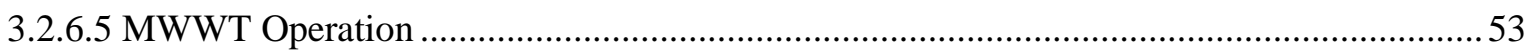

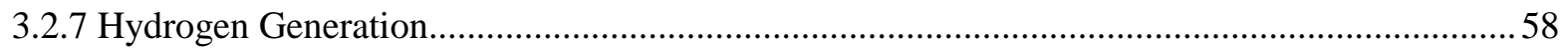

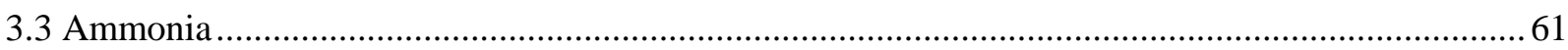

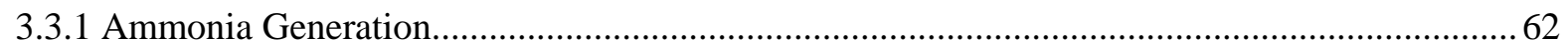

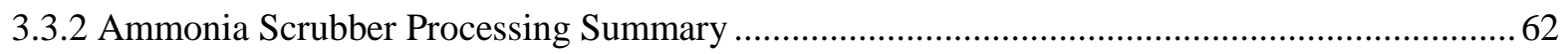




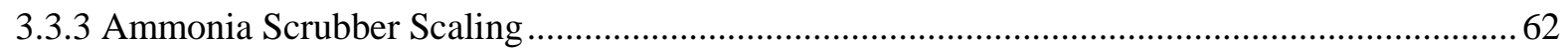

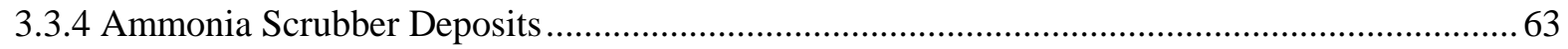

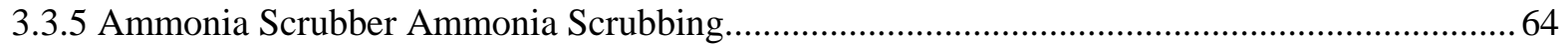

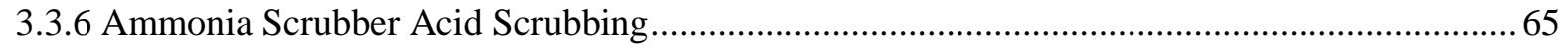

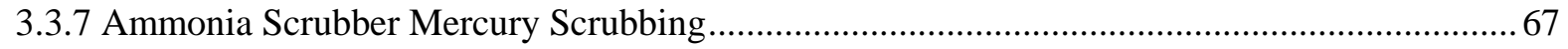

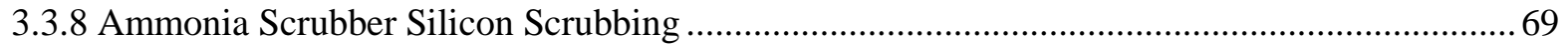

3.4 Condensate Generated During SRAT and SME Cycles................................................................ 71

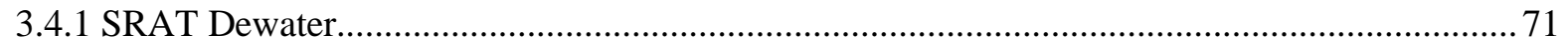

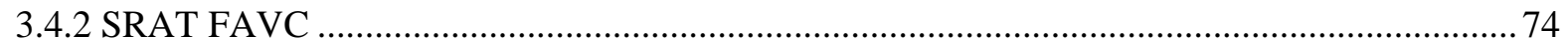

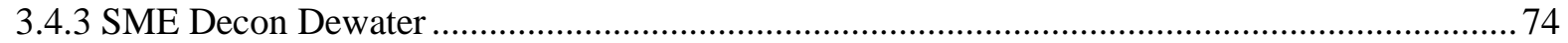

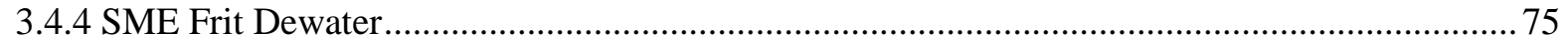

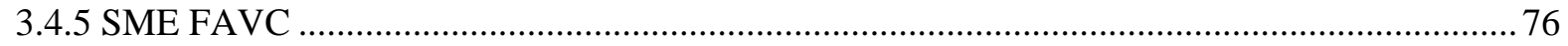

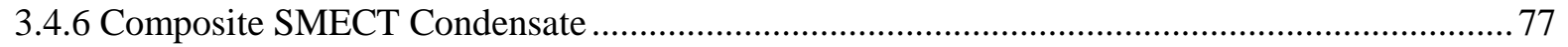

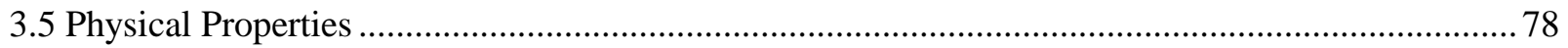

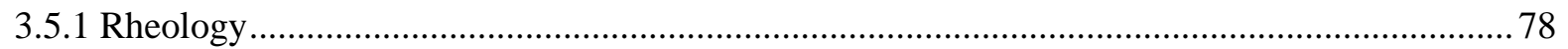

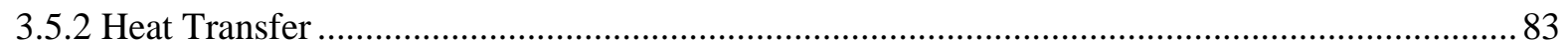

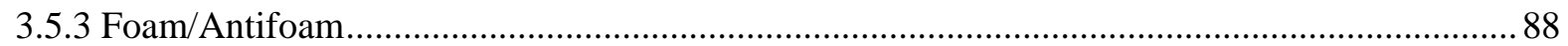

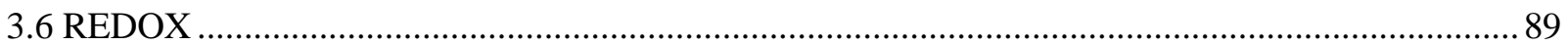

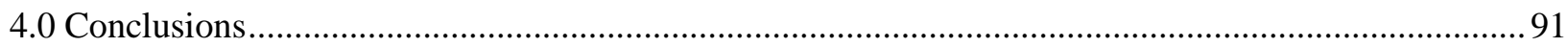

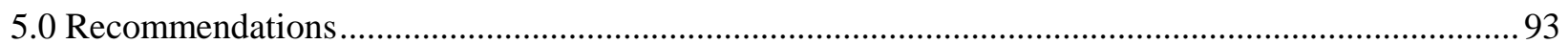

Recommendations Prior to Implementation of the Nitric-Glycolic Flowsheet in DWPF ........................93

Recommendations for Improving Sludge Processing in DWPF .......................................................... 93

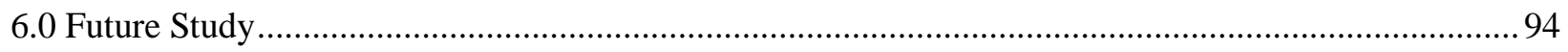

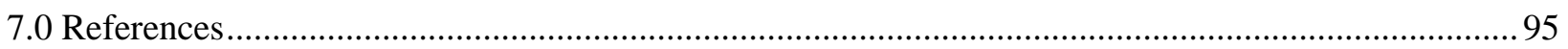

Appendix A GN71 and GN72 SRAT/SME Cycles ........................................................................

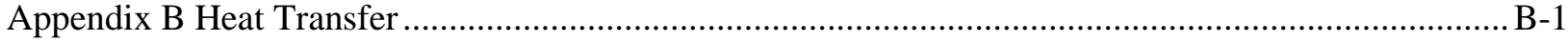

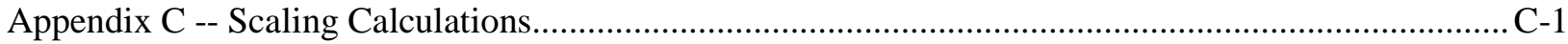

Appendix D - Nitrogen and Carbon Mass Balance Details.......................................................................

Appendix E - GC SRAT and SME Cycle Offgas Plots........................................................................ E-1 


\section{LIST OF TABLES}

Table 2-1. Simulant and Radioactive Elemental composition of calcined Sludge at $1100^{\circ} \mathrm{C}$, wt $\% \ldots \ldots \ldots . . .2$

Table 2-2. Simulant and Radioactive Sludge Properties........................................................................ 3

Table 2-3. Noble metal and mercury, wt $\%$ in total solids......................................................................

Table 2-4. Acid Calculation Results, mol acid/L for trimmed slurry ................................................... 4

Table 2-5. Targeted Mass of Sludge and Frit Added to Each Test ......................................................... 6

Table 3-1. Overall Summary of Scaled Experiments............................................................................... 16

Table 3-2. Stoichiometric Acid Factors Used in Acid Equations ....................................................... 17

Table 3-3. Overall Mass Balance and Processing Time Summary ........................................................ 18

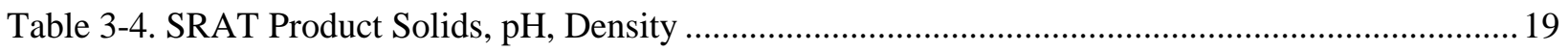

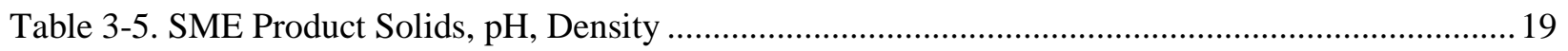

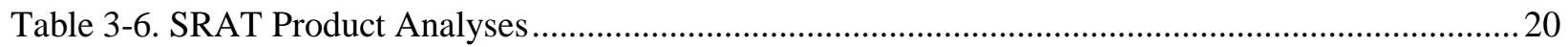

Table 3-7. SRAT Product \% of Element Soluble in Slurry ................................................................. 21

Table 3-8. SME Product \% of Element Soluble in Slurry …................................................................. 21

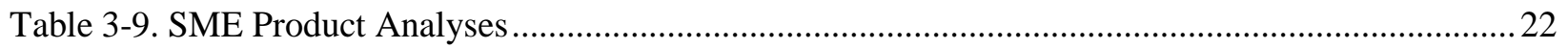

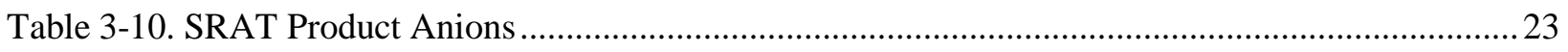

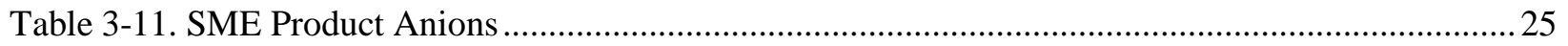

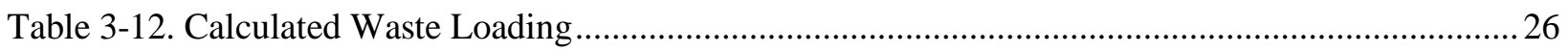

Table 3-13. SRAT and SME Product Anion Cation Balance, M...........................................................26

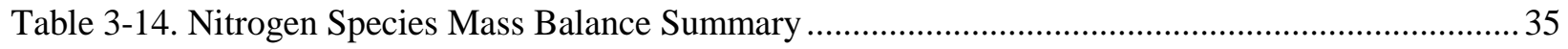

Table 3-15. Percentage of $\mathrm{NO}_{\mathrm{x}}$ Found in Condensates and NO/NO $\mathrm{x}_{\mathrm{x}}$ Ratio - A Function of Scale ............ 36

Table 3-16. Nitrite Conversion to Nitrate - A Function of Acid Stoichiometry …................................... 38

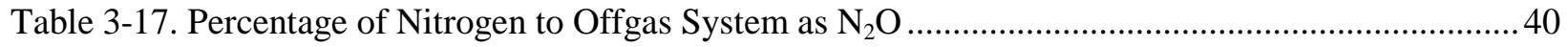

Table 3-18. Carbon Species Mass Balance Summary …....................................................................... 43

Table 3-19. Glycolate Destruction from Offgas and Glycolate Measurements* by Acid Stoichiometry... 44

Table 3-20. Effect of Uncertainty on Glycolate Destruction Calculated from Glycolate Analyses ........... 44

Table 3-21. Glycolate Destruction from Offgas and Glycolate Measurements* by Scale ........................ 45

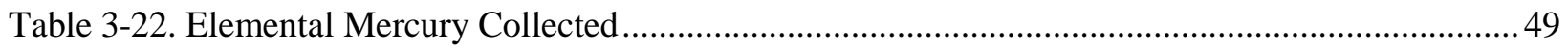




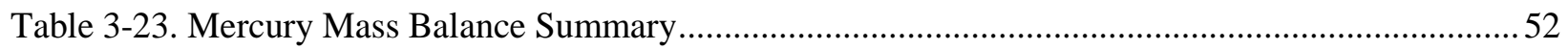

Table 3-24. Maximum Concentrations of Hydrogen Measured by GC and MS ........................................5 59

Table 3-25. Maximum concentrations of hydrogen encountered in runs GN70, GN78 and GN79 ........... 61

Table 3-26. DWPF-scale generation rates of hydrogen from runs GN70, GN78 and GN79 ...................61

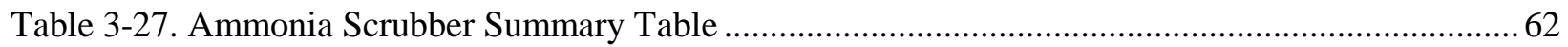

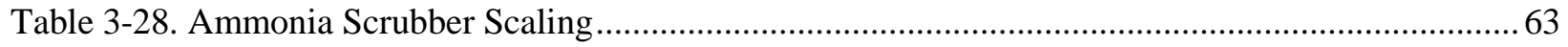

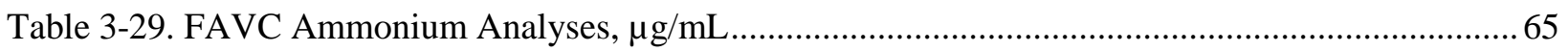

Table 3-30. Hg Mass Balance for Ammonia Scrub Solution....................................................................68

Table 3-31. Post SRAT and SME Ammonia Scrub Solution Mercury Concentration .............................. 69

Table 3-32. Post SRAT Ammonia Scrub Solution Cation Analyses, mg/L ........................................... 69

Table 3-33. Post SME Ammonia Scrub Solution Cation Analyses, mg/L .............................................. 70

Table 3-34. Post SRAT Dewater Anion Analyses, mg/L, Density, g/mL, pH ....................................... 73

Table 3-35. Post SRAT Dewater Cation Analyses, mg/L.................................................................... 73

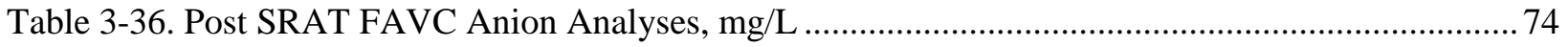

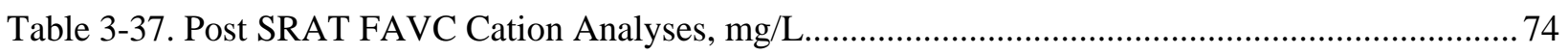

Table 3-38. Post SME Decon Dewater Anion Analyses, mg/L, Density, g/mL, $\mathrm{pH}$................................ 75

Table 3-39. Post SME Decon Dewater Cation Analyses, mg/L ......................................................... 75

Table 3-40. Post SME Frit Dewater Anion Analyses, mg/L, Density, g/mL, pH....................................76

Table 3-41. SME Post Frit Dewater Cation Analyses, mg/L ................................................................ 76

Table 3-42. Post SME FAVC Anion Analyses, mg/L ......................................................................... 77

Table 3-43. Post SME FAVC Cation Analyses, mg/L........................................................................... 77

Table 3-44. Calculated Composition of SRAT and SME Cycle SMECT Condensate, $\mathrm{mg} / \mathrm{L} \ldots \ldots \ldots \ldots \ldots \ldots \ldots . . . . .78$

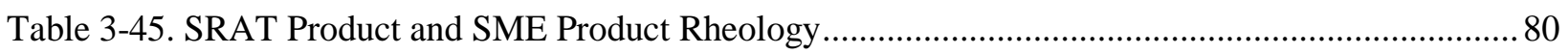

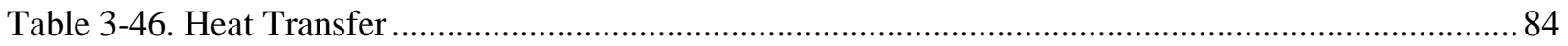

Table 3-47. SRAT and SME Antifoam Strategy for Nitric-Glycolic and Nitric-Formic Flowsheets.......... 89

Table 3-48. Calculated Boiling Flux in SRAT for Scaled Experiments ................................................... 89

Table 3-49. REDOX of Glass (CC Hot) Produced from SME Product...................................................... 90 


\section{LIST OF FIGURES}

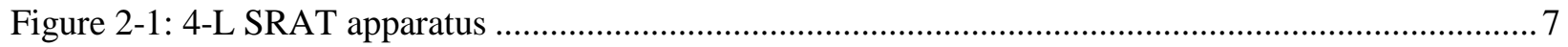

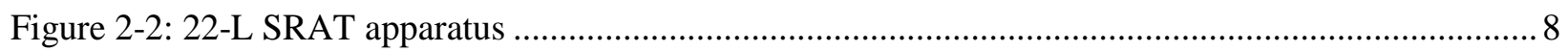

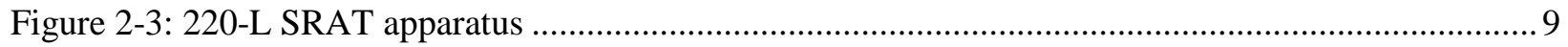

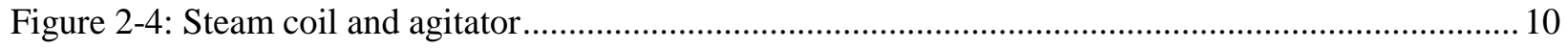

Figure 2-5: SRAT condenser bottom for 220-L setup ......................................................................... 10

Figure 2-6: SRAT condenser for 220-L setup …................................................................................. 11

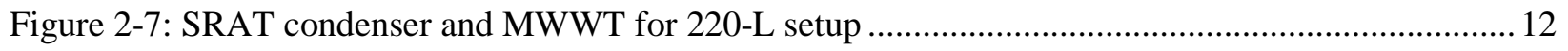

Figure 3-1. Offgas Concentrations from 100\% Stoichiometry Runs .................................................. 28

Figure 3-2. Offgas Concentrations from 110\% Stoichiometry Runs …................................................ 29

Figure 3-3. GN77 HMDSO Concentration ...................................................................................... 31

Figure 3-4. Ratio of Cumulative HMDSO Evolved in SRAT and SME Cycle to Antifoam Added....... 32

Figure 3-5. Decomposition Pathway for Antifoam............................................................................... 33

Figure 3-6. GN75 SRAT Cycle Nitrogen to Helium Ratio........................................................................ 34

Figure 3-7. Early SRAT Cycle $\mathrm{NO}_{\mathrm{x}}$ Concentrations …...................................................................... 37

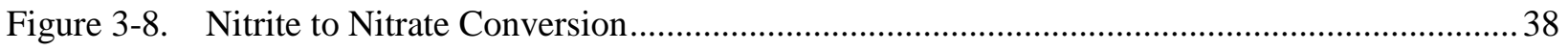

Figure 3-9. Nitrate to Nitrate Conversion Linear Fit to Acid Stoichiometry ......................................... 39

Figure 3-10. Nitrite Destruction during SRAT Cycle ............................................................................... 41

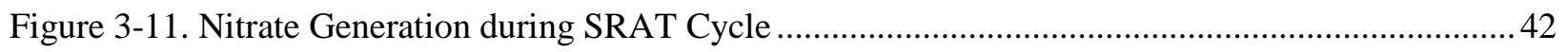

Figure 3-12. SRAT and SME Cycle HMDSO Concentration for GN77 ….......................................... 46

Figure 3-13. GN70, GN74, GN76, GN79 Mercury Concentration in Slurry Samples, mg/kg.................. 47

Figure 3-14. GN73, GN75, GN77 and GN78 Mercury Concentration in Slurry Samples, mg/kg ............. 48

Figure 3-15: GN78-110 Mercury collection in the MWWT (four hours into SRAT reflux)..................... 49

Figure 3-16: GN78-110 Mercury collection in the MWWT (28 hours into SRAT reflux) ....................... 50

Figure 3-17: GN79-100 Mercury collection in the MWWT (32 hours into SRAT reflux) ....................... 51

Figure 3-18: Mercury Observed in the 4-L MWWT …............................................................................. 53

Figure 3-19: Mercury collection in the 220-L SRAT condenser ........................................................... 54

Figure 3-20. GN 78 and GN79 MWWT Aqueous Nitrate, mg/L and GN79 pH.................................... 55 


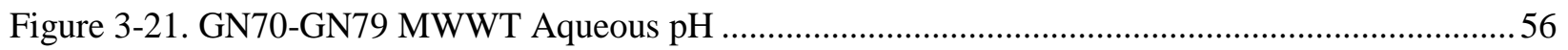

Figure 3-22. GN78 and GN79 MWWT Aqueous Dissolved Mercury Concentration, mg/L ..................... 57

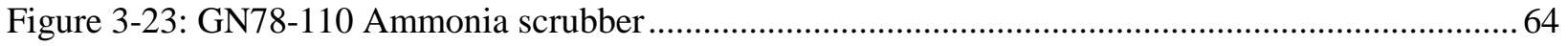

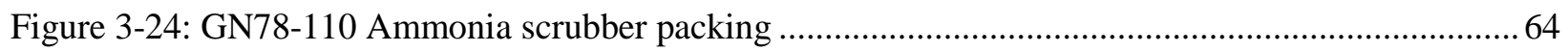

Figure 3-25. Ammonia Scrub Solution Nitrate Concentration during SRAT Cycle .................................66

Figure 3-26. Ammonia Scrub Solution Formate Concentration during SRAT Cycle ..............................67

Figure 3-27. Ammonia Scrub Solution Mercury Concentration, mg/L ................................................ 68

Figure 3-28. Ammonia Scrub Solution Silicon Concentration during SRAT Cycles................................. 71

Figure 3-29. GN70 Cooling Water, Condensate, and Offgas Temperature Profile ................................... 72

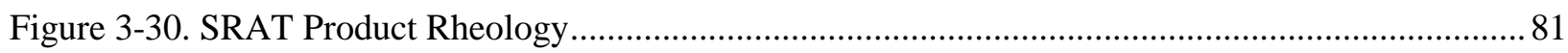

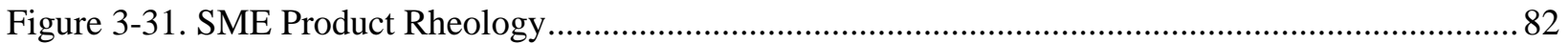

Figure 3-32. SRAT and SME Product Rheology versus Acid Stoichiometry …...................................... 83

Figure 3-33. GN79 Calculated Heat Transfer Coefficient Using Measured Steam and Calculated Steam

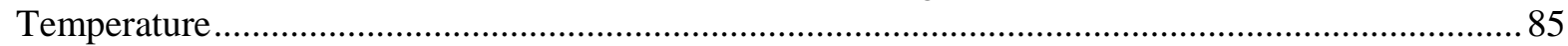

Figure 3-34. SRAT and SME Cycle Heat Transfer Coefficient Comparison for GN78 and GN79 ...........86

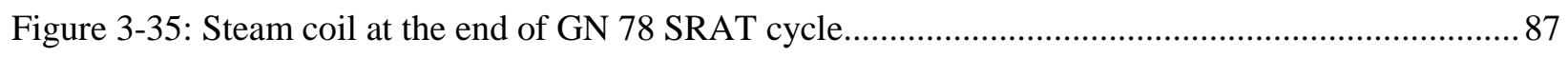

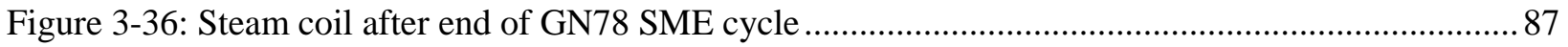

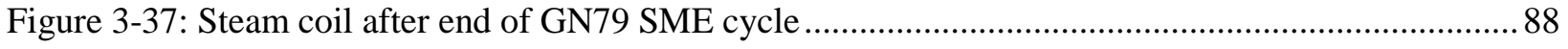




\section{LIST OF ABBREVIATIONS}

\begin{tabular}{|c|c|}
\hline ACTL & Aiken County Technology Laboratory \\
\hline ARP & Actinide Removal Process \\
\hline CCHot & Closed Crucible Method Inserting into Hot Furnace \\
\hline CETL & Clemson Environmental Technologies Laboratory \\
\hline СРC & Chemical Processing Cell \\
\hline CQ & Caustic quench \\
\hline DC & Direct Current \\
\hline DWPF & Defense Waste Processing Facility \\
\hline EDL & Engineering Development Laboratory \\
\hline ELN & Electronic Lab Notebook \\
\hline FAVC & Formic Acid Vent Condenser \\
\hline FTIR & Fourier transform infrared spectrometer (or spectroscopy) \\
\hline GC & Gas chromatograph (or chromatography) \\
\hline GMA & Glycolic Minimum Acid \\
\hline HMDSO & Hexamethyldisiloxane \\
\hline IC & Ion Chromatography \\
\hline ICP-AES & Inductively Coupled Plasma-Atomic Emission Spectroscopy \\
\hline KMA & Koopman Minimum Acid \\
\hline lpm & Liters per minute \\
\hline $\mathrm{m} / \mathrm{z}$ & MS mass-to-charge ratio \\
\hline MCU & Modular Caustic-Side Solvent Extraction Unit \\
\hline MS & Mass spectrometer (or spectrometry) \\
\hline MWWT & Mercury Water Wash Tank \\
\hline NIST & National Institute of Standards and Technology \\
\hline $\mathrm{NO}_{\mathrm{x}}$ & $\mathrm{NO}+\mathrm{NO}_{2}$ \\
\hline $\mathrm{N}_{\mathrm{y}} \mathrm{O}_{\mathrm{x}}$ & $\mathrm{NO}+\mathrm{NO}_{2}+\mathrm{N}_{2} \mathrm{O}$ \\
\hline PEG & Poly(ethylene)glycol \\
\hline PSAL & Process Science Analytical Laboratory \\
\hline PSED & Polymeric siloxane ethoxylated derivative \\
\hline REDOX & REDuction/OXidation \\
\hline RPM & Revolutions Per Minute \\
\hline SB & Sludge Batch \\
\hline scfm & Standard Cubic Feet per Minute \\
\hline SME & Slurry Mix Evaporator \\
\hline SMECT & Slurry Mix Evaporator Condensate Tank \\
\hline SRAT & Sludge Receipt Adjustment Tank \\
\hline SRNL & Savannah River National Laboratory \\
\hline SRR & Savannah River Remediation \\
\hline TTQAP & Task Technical \& Quality Assurance Plan \\
\hline TTR & Technical Task Request \\
\hline
\end{tabular}




\subsection{Introduction}

Savannah River Remediation (SRR) is evaluating changes to its current Defense Waste Processing Facility (DWPF) flowsheet to reduce facility hazards and improve processing cycle times. The focus of the project is to reduce facility hazards related to formic acid, to improve $\mathrm{pH}$ stability, rheological control, and have lower offgas flammability concerns (e.g., hydrogen) compared to the nitric-formic acid flowsheet. The nitric-glycolic acid flowsheet will also enable the facility to have a greater ability to support higher canister production while maximizing waste loading. Higher throughput is needed in the Chemical Processing Cell (CPC) since the installation of the bubblers into the melter has increased melt rate. Due to the significant maintenance required for the DWPF gas chromatographs (GC) and the production of flammable quantities of hydrogen in the CPC, eliminating the use of formic acid is desired. Development at the Savannah River National Laboratory (SRNL) has shown that replacing formic acid with glycolic acid allows the reduction and removal of mercury in the Sludge Receipt Adjustment Tank (SRAT) without significant catalytic hydrogen generation. ${ }^{1,2,3,4,5}$

The main test objective was to demonstrate the scalability of CPC simulation runs for the nitric-glycolic acid flowsheet. The majority of testing on the new flowsheet has and will continue to be performed on relatively small scales (4-L kettles for nonradioactive simulants and 1.2-L or 4-L kettles for actual waste). This testing provides information needed to bridge the gap to the facility scale. Testing with nonradioactive simulant was successfully completed at three experimental scales. This testing was designed to determine if there are any issues concerning scale-up of the flowsheet. Specifically, this testing evaluates the impact of the equipment scale on process chemistry, offgas composition, product rheology, and glass REDuction/OXidation (REDOX). This work is outlined in Task 2.f. of the Technical Task Request (TTR) ${ }^{6}$ and Section 4.4 of the Task Technical \& Quality Assurance Plan (TTQAP). ${ }^{7}$

The three scales used in this study involved a 4-L glass kettle, a 22-L glass kettle and a 220-L stainless steel kettle. These are compared with the roughly 36,000 L SRAT and Slurry Mix Evaporator (SME) vessels in DWPF. For scaling purposes, the starting sludge volumes (no heel) for the $4 \mathrm{~L}, 22 \mathrm{~L}$ and $220 \mathrm{~L}$ was based on a DWPF sludge feed of 22,680 L (6000 gal). Heating methods differed between the different scales, with the small (4-L) and intermediate (22-L) vessels heated with electrical heating rods and the large (220-L) vessel heated with steam coils. Mixing in the CPC simulant runs was not rigorously scaled from the DWPF vessels, but adequate mixing (mixing at surface and sides of kettle, essentially equivalent) is provided at each scale to study reaction chemistry.

In this scaled demonstration, individual tests were replicated on all three scales. Additional small scale tests were performed to ensure the REDOX target for each acid stoichiometry was met prior to repeating the test at a larger scale. For the intermediate and large scale, tests were performed at two acid stoichiometries. All tests included mercury 5\% higher and noble metal 25\% higher than SB8 blend target concentrations, which extended the SRAT boiling times to approximately 36 hours. The SME cycle included a scaled 6,000 gallon addition of water to simulate the canister decontamination frit water addition, which extended the SME boiling time to about 45 hours. No Actinide Removal Process (ARP) or Modular Caustic-Side Solvent Extraction Unit (MCU) addition was simulated during this testing as the addition of these streams lowers the concentration of noble metals and results in lower hydrogen generation.

\subsection{Experimental Procedure}

\subsection{Simulant Preparation and Characterization}

In 2007, three generic simulants designated A, B, and C were prepared. ${ }^{8}$ These simulants were designed to be blended in varying proportions to achieve a range of desired chemical compositions. Other chemicals 
could then be added to supply missing elements. Note that the rheology is a by-product of the simulant recipe/preparation method and does not mimic the rheology of the actual radioactive slurry.

For the scaled testing of the alternate reductant flowsheet, a simulant similar in composition and noble metals concentration to sludge batch (SB) 8 , Tank $40^{9}$ was targeted. The base simulant was prepared by blending 87 liters of simulant B with 156 liters of simulant C and 293 liters of DI water. Soluble supernate species and insoluble trim chemicals were added. The resulting Final Blend simulant composition and comparison to SB8-Tank 40 after trimming with sodium nitrite and sodium hydroxide (but not noble metals, mercury, and rinse water) are shown in Table 2-1 and Table 2-2.

Table 2-1. Simulant and Radioactive Elemental composition of calcined Sludge at $1100^{\circ} \mathrm{C}$, wt \%

\begin{tabular}{|c|c|c|c|c|}
\hline Element & B & C & $\begin{array}{c}\text { SB8 } \\
\text { Tk40 }\end{array}$ & $\begin{array}{c}\text { Final } \\
\text { Blend }\end{array}$ \\
\hline $\mathrm{Al}$ & 6.3 & 13.2 & 9.51 & 10.0 \\
\hline $\mathrm{Ba}$ & 0.2 & 0.2 & 0.12 & 0.2 \\
\hline $\mathrm{Ca}$ & 3.7 & 2.5 & 1.44 & 1.7 \\
\hline $\mathrm{Cu}$ & 0.1 & 0.1 & 0.05 & 0.1 \\
\hline $\mathrm{Fe}$ & 37.6 & 35.5 & 22.15 & 24.4 \\
\hline $\mathrm{K}$ & 0.2 & 0.2 & 0.11 & 0.2 \\
\hline $\mathrm{Mg}$ & 0.1 & 0.2 & 0.31 & 0.3 \\
\hline $\mathrm{Mn}$ & 12.1 & 4.1 & 7.18 & 7.4 \\
\hline $\mathrm{Na}$ & 4.8 & 3.4 & 17.39 & 17.6 \\
\hline $\mathrm{Ni}$ & 0.3 & 4.9 & 2.18 & 2.2 \\
\hline $\mathrm{S}$ & 0.3 & 0.3 & 0.55 & 0.4 \\
\hline $\mathrm{Si}$ & 1.4 & 1.3 & 1.36 & 1.7 \\
\hline $\mathrm{Ti}$ & 0.0 & 0.0 & 0.02 & $<0.1$ \\
\hline $\mathrm{Zn}$ & 0.1 & 0.1 & 0.04 & $<0.1$ \\
\hline $\mathrm{Zr}$ & 0.5 & 0.2 & 0.13 & 0.2 \\
\hline
\end{tabular}


Table 2-2. Simulant and Radioactive Sludge Properties

\begin{tabular}{|c|c|c|c|c||}
\hline Analyte & B & C & $\begin{array}{c}\text { SB8 } \\
\text { Tk40 }\end{array}$ & $\begin{array}{c}\text { Final } \\
\text { Blend }\end{array}$ \\
\hline Total solids, wt.\% & 17.54 & 22.94 & 17.21 & 17.50 \\
\hline Insoluble solids, wt.\% & 15.88 & 21.62 & 11.32 & 11.62 \\
\hline Soluble solids, wt.\% & 1.66 & 1.32 & 5.89 & 5.88 \\
\hline Calcined solids, wt.\% & 13.85 & 17.74 & 13.13 & 13.2 \\
\hline Slurry density, g/mL & 1.11 & 1.18 & 1.16 & 1.14 \\
\hline Supernate density, g/mL & 1.02 & 1.01 & 1.06 & 1.05 \\
\hline Nitrite, mol/L & 0.094 & 0.123 & 0.292 & 0.235 \\
\hline Nitrate, mol/L & 0.042 & 0.048 & 0.153 & 0.115 \\
\hline Sulfate, mol/L & 0.020 & 0.018 & 0.0193 & 0.0153 \\
\hline Oxalate, mol/L & 0.012 & 0.012 & 0.0248 & 0.0201 \\
\hline Chloride, mol/L & 0.018 & 0.025 & 0.0018 & 0.0083 \\
\hline
\end{tabular}

The mercury was added at 105\% of the SB8 target and the noble metals were added at $125 \%$ of the SB8 target (identical to SB8 blend simulant testing). ${ }^{9}$ Rhodium was trimmed as a solution of $\mathrm{Rh}\left(\mathrm{NO}_{3}\right)_{3}$ containing $4.93 \mathrm{wt} \% \mathrm{Rh}$. Ruthenium was added as the dry trivalent chloride salt at an assay of $41.74 \mathrm{wt} \%$ $\mathrm{Ru}$. Palladium was trimmed as a solution of $\mathrm{Pd}\left(\mathrm{NO}_{3}\right)_{2}$ containing $15.27 \mathrm{wt} \% \mathrm{Pd}$. Silver was added as the dry nitrate salt $\mathrm{AgNO}_{3}$. Mercury was trimmed as dry $\mathrm{HgO}$ (yellow mercuric oxide, which is more finely ground than red mercuric oxide). Targets for the test simulant (D. C. Koopman, personal communication, May 6, 2013) are presented in Table 2-3 along with the SB8 values for comparison.

Table 2-3. Noble metal and mercury, wt\% in total solids

\begin{tabular}{||l|c|c||}
\hline \hline & SB8-Tank 40 & $\begin{array}{c}\text { Scaled Testing } \\
\text { Simulant }\end{array}$ \\
\hline Hg, wt\% & 2.04 & 2.14 \\
\hline Rh, wt\% & 0.0140 & 0.0175 \\
\hline Ru, wt\% & 0.0664 & 0.0830 \\
\hline Pd, wt\% & 0.0027 & 0.0034 \\
\hline Ag, wt\% & 0.0131 & 0.0164 \\
\hline
\end{tabular}

\subsection{Chemical Process Cell Equipment and Testing}

Testing was completed at three different scales (4-L, 22-L, and 220-L scale) to demonstrate the viability of the glycolic acid flowsheet. The largest scale testing was $220-\mathrm{L}$ or $1 / 216^{\text {th }}$ DWPF scale. The key information concerning the experimental equipment is summarized in section 2.2.1, 2.2.2, and 2.2.3. The testing was performed to simulate sludge-only processing in DWPF using a Tank 40 sludge simulant.

Koopman minimum acid $^{\mathbf{1 0}}$ (KMA): Initial simulant acid calculations were based on the KMA requirement (Equation [1]) for the nitric-formic acid flowsheet (all terms have units of moles/L slurry). The KMA stoichiometry will be used throughout this report for convenience since the GN stoichiometry has not been validated. A KMA stoichiometric factor of 100\%-125\% was used for the testing.

$$
\frac{\text { mols acid }}{L \text { slurry }}=\frac{[\text { base equivalents }+H g+T I C \text { soluble }+ \text { nitrite }+1.5 \times(C a+M g+M n)]}{L}
$$


Hsu acid equation: A parallel acid calculation was also performed using the current DWPF algorithm (Hsu Equation [2]) for comparison: ${ }^{10}$

$$
\frac{\text { moles acid }}{\text { L slurry }}=[\text { base equivalents }+2 \times \text { total TIC }+0.75 \times \text { nitrite }+1.2 \times M n+H g] / L
$$

Glycolic/Nitric minimum acid (GMA) ${ }^{11}$ : A proposed acid equation was developed for the glycolic/ nitric flowsheet. The chemistry is described in section 3.1. Since glycolic acid is a better reductant than formic acid, less glycolic acid is needed to complete the required reaction than with the formic acid. Other parameters used for the KMA equation were retained (GMA Equation [3]).

$$
\frac{\text { moles acid }}{L \text { slurry }}=\left[\text { base equivalents }+\frac{H g}{3}+\text { soluble TIC }+\frac{\text { nitrite }}{2}+1.5 x(C a+M g)+\frac{M n}{3}\right] / L
$$

The results of the acid calculations for the trimmed simulants are summarized in Table 2-4. The table also includes the actual acid additions made based on $110 \%$ of the Koopman minimum acid equation and the equivalent DWPF stoichiometric factors (percent) for the Hsu and GMA values.

Table 2-4. Acid Calculation Results, mol acid/L for trimmed slurry

\begin{tabular}{|c|c|c|c|c|}
\hline Run & stoichiometry & $\begin{array}{c}\text { Hsu } \\
\text { moles/L }\end{array}$ & $\begin{array}{c}\text { KMA } \\
\text { moles/L* }\end{array}$ & $\begin{array}{c}\text { GMA } \\
\text { moles/L }\end{array}$ \\
\hline $\begin{array}{l}\text { GN70, } \\
\text { GN72, } \\
\text { GN74, } \\
\text { GN76, } \\
\text { GN79 }\end{array}$ & 100 & 1.27 & 1.36 & 0.988 \\
\hline $\begin{array}{l}\text { GN73, } \\
\text { GN75, } \\
\text { GN77, } \\
\text { GN78 }\end{array}$ & 110 & 1.40 & 1.49 & 1.09 \\
\hline GN71 & 125 & 1.59 & 1.70 & 1.24 \\
\hline
\end{tabular}

* KMA Equation [1] was used for all calculations. Hsu and GMA are shown for information

Total acid demand was partitioned between glycolic and nitric acids to target the planned glass REDOX. $^{12}$

Scaled design basis DWPF SRAT/SME processing conditions for sludge-only SRAT and SME cycles processing were generally used. The SRAT and SME cycles did not have a heel from a prior batch. R\&D directions were prepared for each run and used to supplement the standard SRNL procedure for non-radioactive CPC simulations. ${ }^{13}$ The following parameters were used for all scaled experiments: 


\section{SRAT Cycle}

- $\quad$ The SRAT air purge scaled to $93.7 \mathrm{scfm}$ in DWPF.

- Nitric acid was added at a scaled $4.65 \mathrm{gpm}(178 \mathrm{~mol} / \mathrm{min})$ during heatup and at $93{ }^{\circ} \mathrm{C}$. A $100 \mathrm{ppm}$ antifoam addition was made at $\mathrm{pH} 10$.

- A 100 ppm antifoam addition was made prior to glycolic acid addition.

- $\quad$ The glycolic acid was added at a scale $3.95 \mathrm{gpm}(178 \mathrm{~mol} / \mathrm{min})$ at $93^{\circ} \mathrm{C}$.

- A 100 ppm antifoam addition was made prior to going to boiling following acid addition, and then a 100 ppm antifoam addition was made every 12 hours during boiling in the SRAT.

- $\quad$ SRAT boiling at a condensate production rate of 2,700 lb/hr at DWPF scale.

- $\quad$ SRAT dewatering took about 6 hours to produce 26-28 wt \% total solids slurry.

- Reflux followed dewatering. The end of the 37 hour reflux period defined the end of the SRAT cycle (theoretically this was sufficient to strip mercury to specifications).

\section{SME Cycle}

- The SME air purge scaled to $74 \mathrm{scfm}$ in DWPF.

- A 100 ppm antifoam addition was made at the start of the SME cycle, and then a 100 ppm antifoam addition was made every 12 hours during boiling in the SME.

- Six canister decontamination water additions and dewaterings were simulated to a scaled DWPF volume of 1,000 gallons each at a condensate production rate of 2,200 lb/hr at DWPF scale.

- Two frit 418-water additions were made targeting 36\% waste loading. An equal mass of water was added with no added formic acid.

- The SME was dewatered following each frit slurry addition at a condensate production rate of 2,200 lb/hr at DWPF scale.

- $\quad$ The final SME solids target was $45 \mathrm{wt} \%$.

Antifoam was prepared on the first day of each experiment by diluting Lot\#111128-0613 of Siovation Antifoam 747 to a concentration of $10 \%$ by mass with deionized water. The antifoam solution was stirred on a stir plate for the entire experiment. For each antifoam addition, a subsample from the 1:10 antifoam solution was weighed, added to the antifoam addition funnel, and quickly added by opening the stopcock. The $10 \%$ antifoam solution was followed by an equal mass of deionized water. By the completion of the SME cycle, the $10 \%$ antifoam had been stirred for about four days after dilution.

Samples were taken during each SRAT cycle to monitor the progress of the main reactions. Major cations and anions were checked immediately after each acid addition. Samples were pulled during boiling to monitor suspended and dissolved mercury in the SRAT slurry. These samples were pulled directly into digestion vials to eliminate potential segregation of mercury during sub-sampling/aliquoting steps. The SRAT and SME product slurries were sampled similarly once they had cooled to $90{ }^{\circ} \mathrm{C}$ while the vessel contents were still mixing.

Additional SRAT and SME product samples were taken from each run for compositional and solids analyses as well as for rheological characterization of each slurry. The MWWT and FAVC were drained and the condensates weighed after both the SRAT and SME cycles. Elemental mercury was separated from the aqueous phase in the post-SRAT MWWT sample when possible, and the mass of the mercury-rich material determined.

Gas chromatography offgas data were scaled to DWPF flow rates. The calculation methodology has been previously documented. ${ }^{14}$ An internal standard flow is established with helium. Other gas flow rates are determined relative to helium by taking the ratio of the two gas volume percentages times the helium standard flow. These results are normally scaled by the ratio of 6,000 gallons of fresh sludge divided by the volume of fresh sludge in the simulant SRAT charge. In the SB8 flowsheet simulations, the 
scaling was performed assuming the volume following pre-concentration was equivalent to 6,000 gallons at DWPF scale. Identical logic was used to convert MS and FTIR offgas data to DWPF-scale flow rates.

There are a number of ways to scale an experiment down from a full scale facility. The assumed full scale volume is 6,000 gallons. In the tests reported here, the starting sludge volume varied in the two experiments in the same equipment. As a result, the primary definition of scale will be based on the starting sludge volume compared to 6,000 gallons. Based on the starting volume for each experiment, the mass of sludge, decon water and frit were calculated. The targets are summarized in Table 2-5.

Table 2-5. Targeted Mass of Sludge and Frit Added to Each Test

\begin{tabular}{|l|c|c|c|c|c|}
\hline Component & Sludge & Decon Water & Frit 418 & SRAT Scale & SME Scale \\
\hline GN70-GN75 & $3.300 \mathrm{~kg}$ & $2.400 \mathrm{~kg}$ & $0.600 \mathrm{~kg}$ & $1 / 7,845^{\text {th }}$ & $1 / 7,845^{\text {th }}$ \\
\hline GN76 & $19.13 \mathrm{~kg}$ & $13.40 \mathrm{~kg}$ & $3.474 \mathrm{~kg}$ & $1 / 1,353^{\text {rd }}$ & $1 / 1,353^{\text {rd }}$ \\
\hline GN77 & $17.25 \mathrm{~kg}$ & $12.74 \mathrm{~kg}$ & $3.351 \mathrm{~kg}$ & $1 / 1,501^{\text {st }}$ & $1 / 1,501^{\text {st }}$ \\
\hline GN78 & $124.8 \mathrm{~kg}$ & $94.07 \mathrm{~kg}$ & $25.74 \mathrm{~kg}$ & $1 / 207^{\text {th }}$ & $1 / 207^{\text {th }}$ \\
\hline GN79 & $146.6 \mathrm{~kg}$ & $121.3 \mathrm{~kg}$ & $30.46 \mathrm{~kg}$ & $1 / 177^{\text {th }}$ & $1 / 177^{\text {th }}$ \\
\hline DWPF & $25,890 \mathrm{~kg}$ & & $4,899 \mathrm{~kg}$ & $1 / 1$ & $1 / 1$ \\
\hline DWPF & 6000 gallons & 6,000 gallons & & $1 / 1$ & $1 / 1$ \\
\hline
\end{tabular}

\subsubsection{4-L scaled experiment setup}

The 4-L lab-scale equipment was used for these tests. The 4-L setup included a 4-L glass vessel and lid, SRAT condenser, ammonia scrubber, formic acid vent condenser, mixer, heater, and acid addition pump. A photo of the 4-L rig is shown in Figure 2-1. Details about the design are in the CPC equipment set-up reference. ${ }^{15}$ The trimmed SRAT receipt volume was about $3.0 \mathrm{~L}$ for the $1 / 7,845^{\text {th }}$ scale tests. 


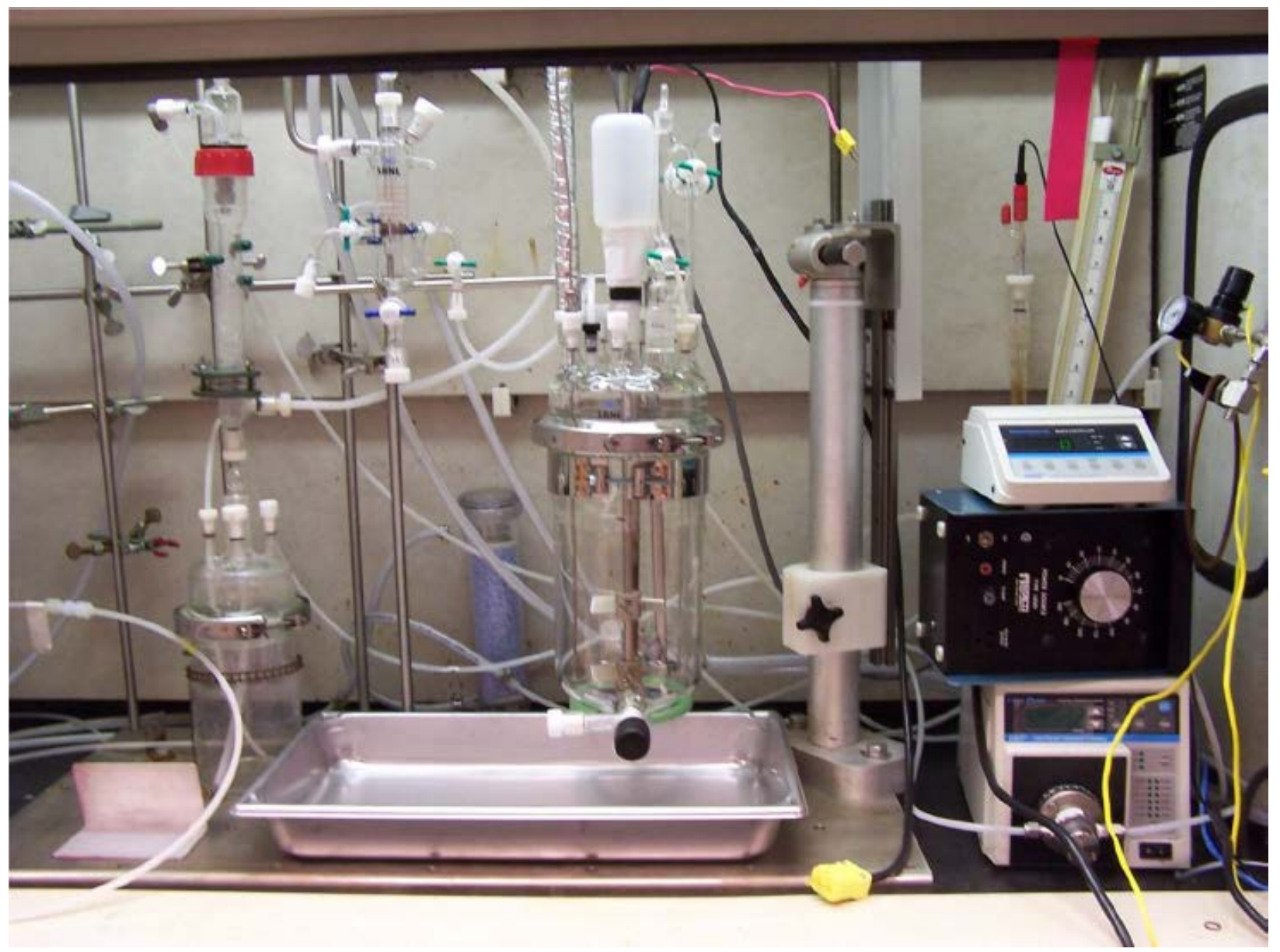

Figure 2-1: 4-L SRAT apparatus

The reservoir below the ammonia scrubber was charged with a solution of $749 \mathrm{~g}$ of de-ionized water and 1 $\mathrm{g}$ of $50 \mathrm{wt} \%$ hydrochloric acid. $\mathrm{HCl}$ was used instead of nitric acid to eliminate the addition of nitrate to the $\mathrm{pH} 2$ scrub solution. Condensates from the SRAT and SME were not drained into this reservoir. The dilute acid reservoir solution was recirculated by a MasterFlex driven Micropump gear pump at about 300 $\mathrm{mL}$ per minute to a spray nozzle at the top of the packed section. The main purpose of the lab-scale ammonia scrubber is to collect ammonia vapor in the SRAT/SME condenser offgas for quantification of ammonia generation, whereas the main purpose of the DWPF SRAT and SME ammonia scrubbers is to prevent build-up of ammonium nitrate crystals in the offgas system.

A SRAT condenser/mercury water wash tank (MWWT) combination was used for the SRAT/SME simulations that allow the SRAT/SME condensate to drip vertically into the MWWT at a point below the gas-liquid interface inside the MWWT.

Slurry mixing was controlled using a mixer system consisting of a Servodyne mixing head coupled to an agitator shaft utilizing two 3 inch $45^{\circ}$ pitched turbine impeller blades.

The process air purge system was provided by the building air supply and controlled using a MKS Model 647 Multi Gas Controller. The process air was treated to remove water and $\mathrm{CO}_{2}$. 
Heating was provided using two 0.5 inch stainless steel heating rods powered by an automated direct current (DC) power supply (TDK Lambda Genesys GEN150-10).

\subsubsection{2-L scaled experiment setup}

The 22-L bench-scale equipment was used for these tests. The trimmed SRAT receipt volume was about 17.0 $\mathrm{L}$ for the intermediate scale tests. The 22-L setup utilized a 22-L glass vessel, stainless steel lid, and equipment from the 4-L design: mixer, pumps, purge gas controller, FAVC, and control software. A picture of the SRAT setup is seen in Figure 2-2.

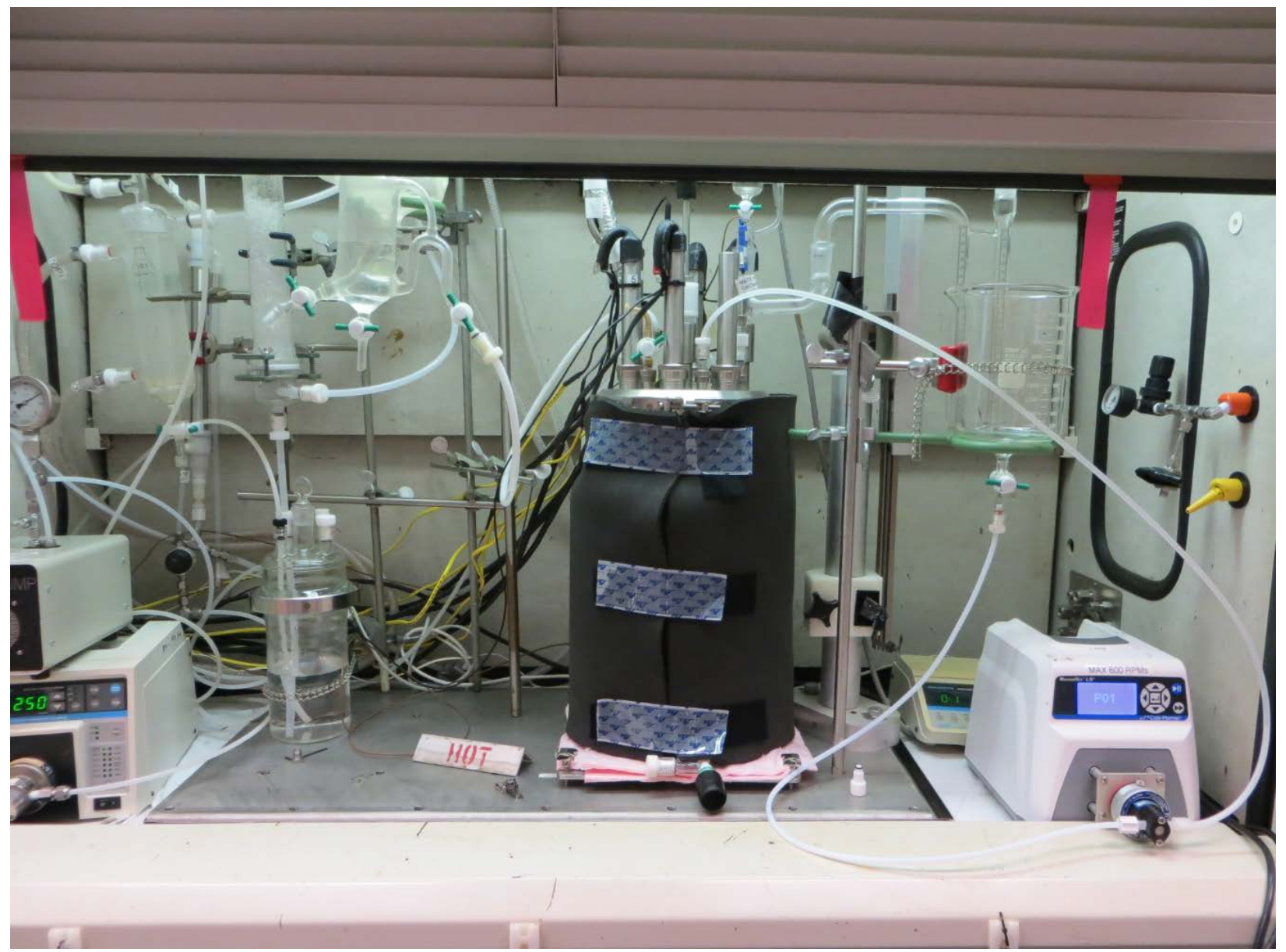

Figure 2-2: 22-L SRAT apparatus

The SRAT condenser and ammonia scrubber were scaled larger to accommodate the larger gas generation and purge flow rates. Heating was provided using four 1.0 inch diameter stainless steel heating rods powered by an automated DC power supply (TDK Lambda Genesys GEN150-10). Mixing was achieved using a 3/8 inch diameter agitator shaft utilizing two 4.25 inch turbine impeller blades.

\subsubsection{0-L scaled experiment setup}

The 220-L engineering scale equipment was used for these tests. The $1 / 216^{\text {th }}$ volumetric scale)) SRAT/SME vessel was fabricated by the Engineering Development Laboratory (EDL) and was designed to be as geometrically similar to the DWPF vessels as possible. ${ }^{16}$ The 220 -L setup utilized a $220-\mathrm{L}$ stainless steel vessel with a 1 inch thick stainless steel lid. The SRAT vessel measured 31.7 inches tall with 23.2 inch inner diameter. This results in a total available volume of 218 liters (58 gallons). The stainless steel tank contains scaled versions of the heating and cooling coils, agitator, mercury sump, and agitator 
and coil guides. ${ }^{17,18}$ Mixing was provided by a 1 horsepower mixer with a gear ratio that provided a maximum mixing speed of 430 revolutions per minute (RPM). A Parr high torque magnetic drive was used to couple the mixer with the agitator shaft in order to eliminate any pressure leak occurring with a shaft seal. Two 6 inch impellers were welded to the 3/4 inch diameter agitator shaft. Extech True-RMS power analyzer model 38083 was utilized to record agitator power, power factor, voltage, and amperage during the tests.

A picture of the equipment is seen in Figure 2-3. A video system was used to periodically record the liquid surface during mixing.

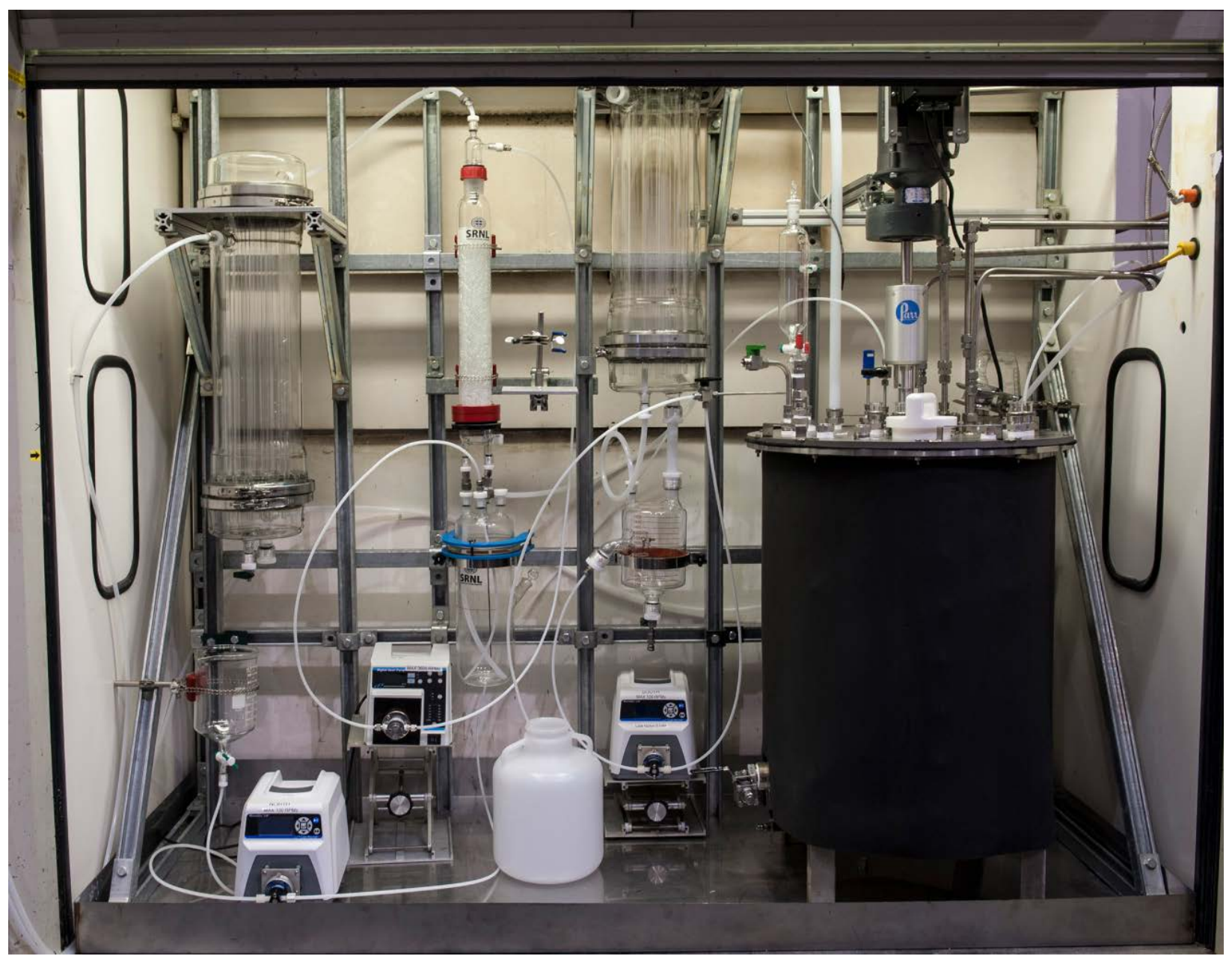

Figure 2-3: 220-L SRAT apparatus

Heat was provided using an Electro-steam Model LG-30 steam generator capable of producing 103 pounds of steam per hour. Steam was introduced into the SRAT vessel through a 3/8 inch stainless steel steam coil (Figure 2-4). Dimensions for the steam coil are approximately 6 inch inside diameter by 10 inch outside diameter by 18 inches tall. Steam flow was controlled using an air actuated steam control valve. The temperature of the solution was measured with a Type K thermocouple. 


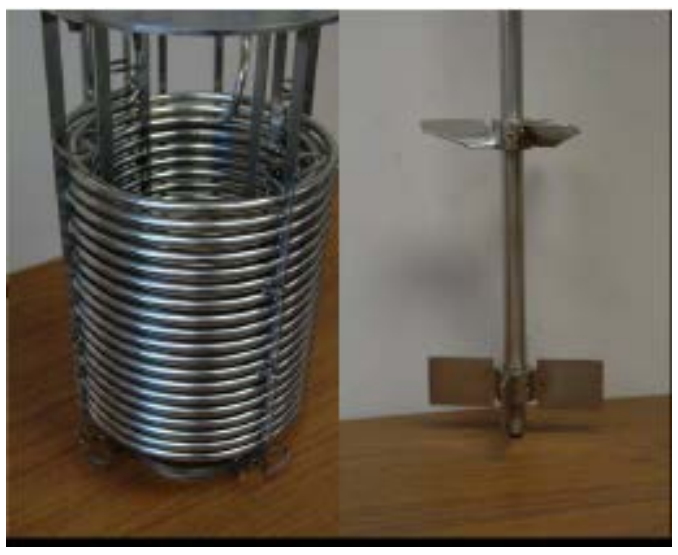

Figure 2-4: Steam coil and agitator

The SRAT condenser (Figure 2-6) was connected to the SRAT vessel using 1 inch Teflon tubing. The condenser was designed to be consistent with the contact time experienced between the DWPF SRAT offgas and condenser. The 220-L scale offgas components were fabricated by the SRNL Technical Glass Development Laboratory. The SRAT condenser was fabricated using 25 internal glass tubes having a diameter of $12 \mathrm{~mm}$ and a length of $610 \mathrm{~mm}$ (24 inches). The glass tubes were enclosed in a $200 \mathrm{~mm}$ glass shell and were secured to the shell utilizing stainless steel plates. Ultra-Torr fittings were welded to the stainless steel plates to allow the inner glass tubes to pass through and create a leak-tight environment (shown in Figure 2-5). The overall length of the condenser was 34 inches.

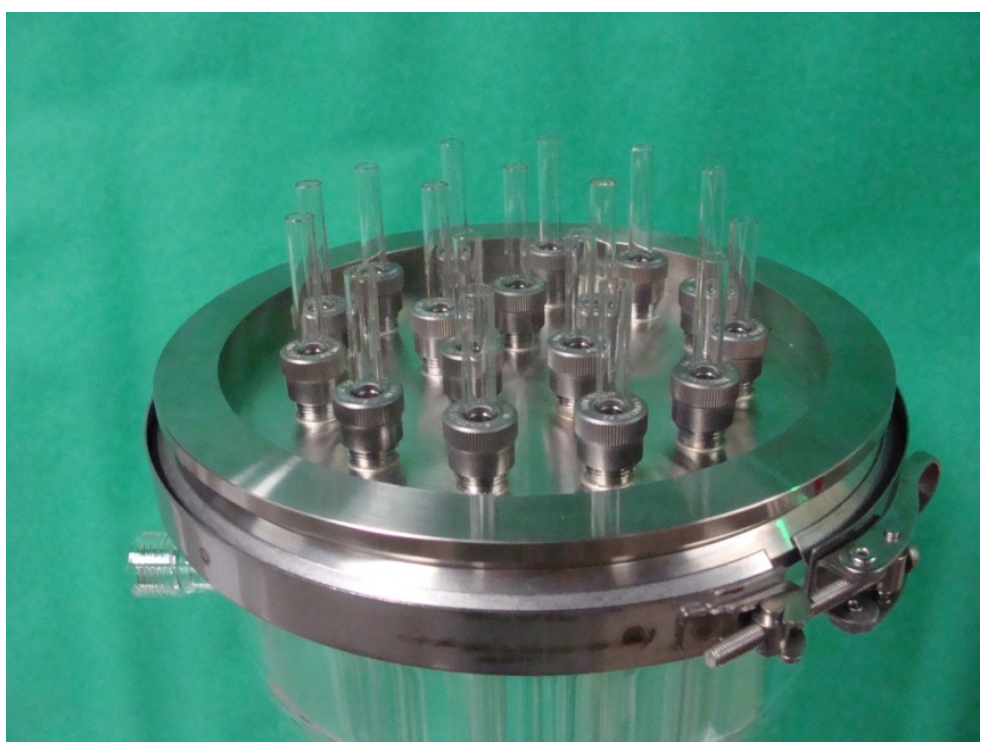

Figure 2-5: SRAT condenser bottom for 220-L setup 


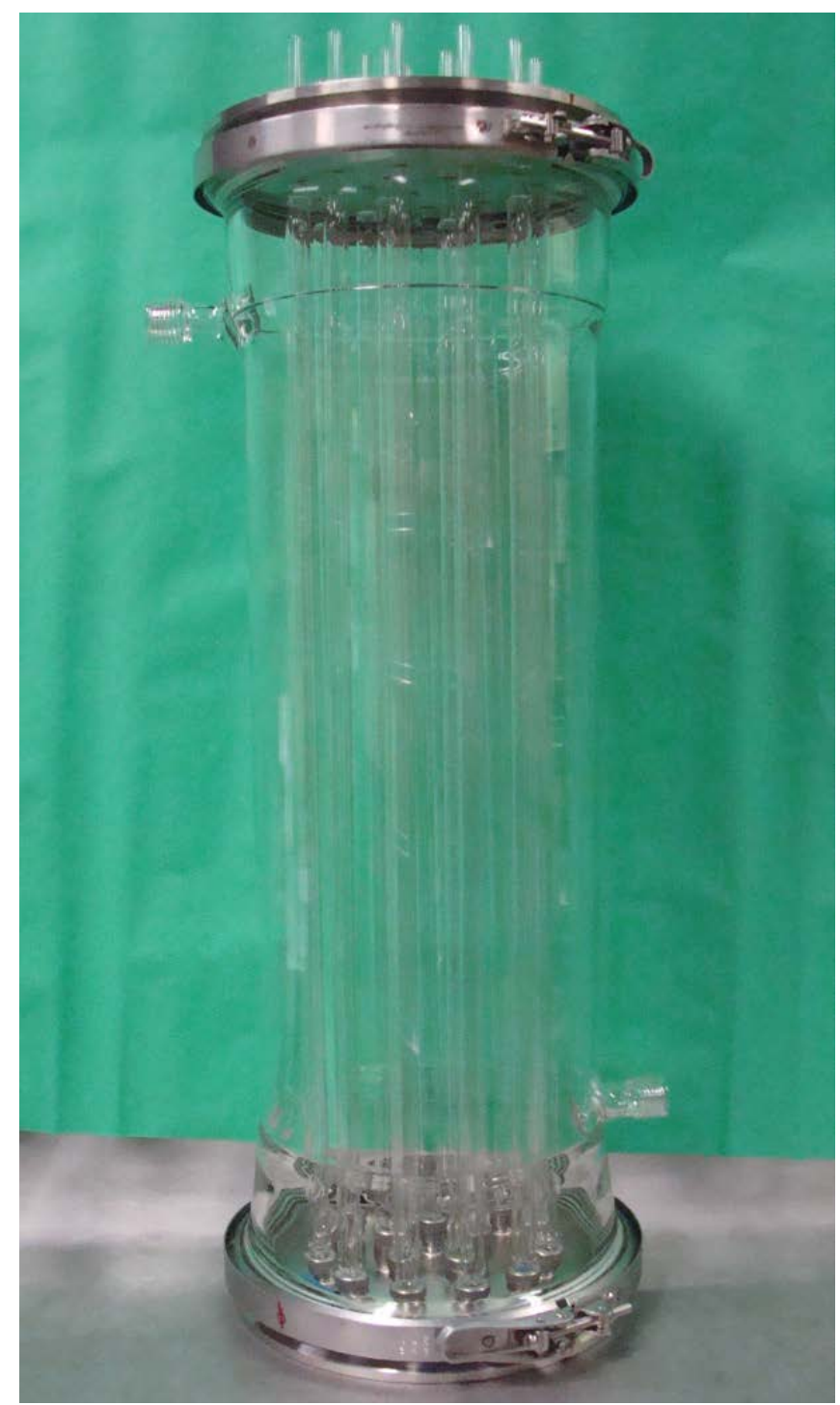

Figure 2-6: SRAT condenser for 220-L setup

The MWWT was designed to sit directly beneath the SRAT condenser. Condensate flowed from the condenser into the MWWT through a 1 inch Teflon tube (Figure 2-7). A 1/2 inch tube was connected between the MWWT and SRAT condenser to prevent any pressure differential. A weir was included to prevent any surface floating mercury from being recirculated into the SRAT vessel during mercury steam stripping. A side port was used to remove condensate from the MWWT using a Masterflex pump. In the 4$\mathrm{L}$ and 22-L setups, this is accomplished by opening a valve and allowing the condensate to gravity drain into the SRAT vessel or carboy. The size of the SRAT condenser required the MWWT to be located below the top of the SRAT vessel, requiring the use of a pump to transfer the condensate back into the SRAT vessel during reflux operations. A bottom port was used to remove the contents of the MWWT during SME product concentration. The diameter and height of the MWWT were 6 inches, resulting in a volume capacity of 2.8-L. 


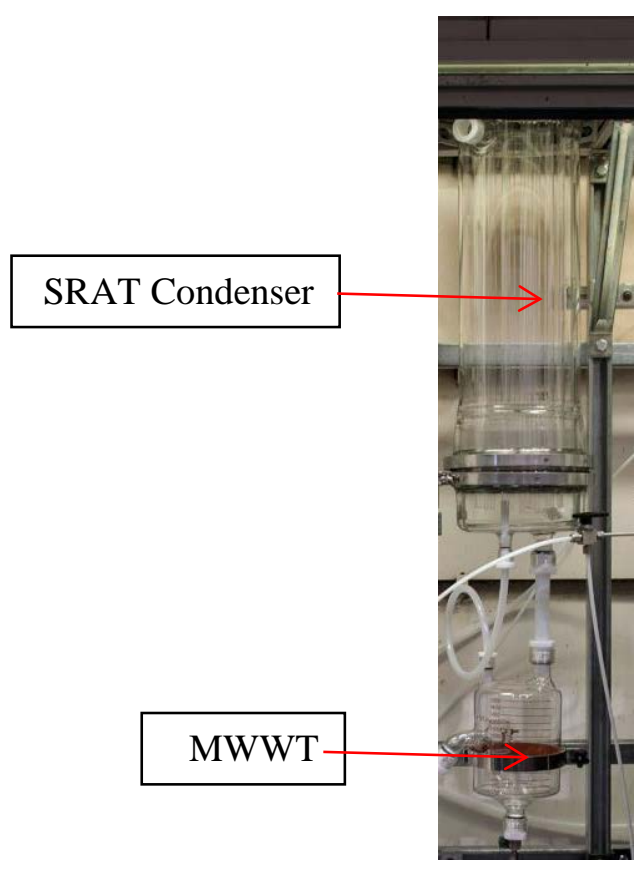

Figure 2-7: SRAT condenser and MWWT for 220-L setup

An ammonia scrubber was fabricated using the same design used for the 4-L and 22-L SRAT vessels. The scrubber had a height of 21 inches and diameter of $3 \frac{1}{1} 2$ inches. The scrubber was filled with $6 \mathrm{~mm} \times 6 \mathrm{~mm} \times$ $1 \mathrm{~mm}$ (L x O.D. $\mathrm{x}$ thickness) borosilicate glass Raschig rings. The same packing material was used in the 4$\mathrm{L}$ and 22-L operations.

The reservoir below the ammonia scrubber was charged with a solution of $2250 \mathrm{~g}$ of de-ionized water and $3 \mathrm{~g}$ of $50 \mathrm{wt} \%$ hydrochloric acid. Condensates from the SRAT and SME were not drained into this reservoir. The dilute acid reservoir solution was recirculated by a MasterFlex driven Micropump gear pump at about $1000 \mathrm{~mL}$ per minute to a spray nozzle at the top of the packed section. The FAVC used in the 220-L experiments was of the same design and dimensions as the SRAT condenser.

\subsection{Process and Sample Analytical Methods}

Ten laboratory-scaled SRAT/SME runs were performed using a simulant similar in composition to Sludge Batch 8. Simulant development and SRAT/SME testing were completed at the Aiken County Technology Laboratory (ACTL). Six runs were performed using the 4-L rigs in preparation for down selecting to two experimental conditions that were performed in both the 22-L rig; and 220-L vessel. The 4-L runs were performed in pairs while the 22-L and 220-L runs were performed singly. All runs were performed using round-the-clock operations.

The automated data acquisition system developed for the 4-L lab-scale SRAT/SME was used to collect electronic data for the 4-L and 22-L experiments. A new data acquisition system was created for the 220-L experiments. Collected data included SRAT slurry temperature, bath temperatures for the SRAT condenser and FAVC cooling water, slurry pH, SRAT mixer speed and torque, air and helium purge flows (helium is used as an internal standard and is set to $0.5 \%$ of the nominal SRAT air purge flow). Air and helium flow data were collected electronically. Individual heating rod temperatures, the total rod current draw, and the total rod power consumption were recorded for the 4- $\mathrm{L}$ and 22-L experiments. These quantities, combined 
with the vessel slurry temperature, permit calculation of a time-dependent heat transfer coefficient between the rods and slurry.

Process samples (liquid, solid, or slurry) were analyzed by various methods. Slurry and supernate elemental compositions were determined by inductively coupled plasma-atomic emission spectroscopy (ICP-AES). Slurry samples were calcined at $1100{ }^{\circ} \mathrm{C}$ and then digested prior to analysis by either lithium metaborate and/or sodium peroxide fusions at the SRNL Process Science Analytical Laboratory (PSAL). Slurry samples were calcined at $1100{ }^{\circ} \mathrm{C}$. The main advantage of this approach is to permit easier comparisons between SRAT product elements and sludge elements. Noble metals and mercury are trimmed uniquely to each SRAT, and the initial concentrations are known more accurately from material balance considerations than they could be from ICP-AES analyses.

Water soluble slurry anions were determined by ion chromatography (IC) on 100-fold weighted dilutions of caustic quenched slurry ( $\sim 2 \mathrm{~mL}$ of $50 \mathrm{wt} \%$ sodium hydroxide solution was added to $\sim 10 \mathrm{~mL}$ of slurry) with water followed by filtration to remove the remaining insoluble solids. IC results were obtained on three slurry samples during the SRAT cycle, as well as on the SRAT and SME products. Anions were also checked in some of the SRAT cycle condensates. Simulants, SRAT products, and SME products were analyzed by PSAL for slurry and supernate density using the Anton-Parr DMA-4500 density instrument. Starting sludge simulants, plus a composite SRAT receipt sample from the flowsheet tests, were titrated to $\mathrm{pH} 7$ using the PSAL auto-titrator to determine the base equivalents for input into the stoichiometric acid equation.

SRAT and SME slurry samples were submitted to PSAL for aqua regia digestion followed by mercury analysis by ICP-AES. Condensate samples (SRAT dewater, SME dewater, FAVC, and ammonia scrubber) received no digestion prior to mercury analysis by ICP-AES.

SRAT and SME product samples were submitted to AD for total inorganic carbon (TIC) and total organic carbon (TOC) analysis. The SRAT receipt sample was submitted to AD for TIC-TOC analysis of both the bulk slurry and the supernate. Samples from the ammonia scrubber reservoir vessel were analyzed by AD using cation chromatography for ammonium ion.

Samples of the SRAT dewater condensate were analyzed for silicon. Antifoam molecules terminate in end groups composed of multi-methyl siloxanes, so silicon is a potential marker for volatilized or steam stripped antifoam lost from the SRAT slurry. The test cannot discriminate between silicon derived from antifoam and silicon from the $\mathrm{SiO}_{2}$ in the slurry, but it can bound potential antifoam losses to the condensate related to $\mathrm{Si}$.

Flow curves for the SRAT and SME products were obtained using a Haake RS600 rheometer and the current DWPF simulant rheology protocol. ${ }^{19}$ The up and down curves were fit to a Bingham plastic model to determine yield stress and consistency. Down flow curve data are the generally preferred choice for comparison.

Gas chromatograph offgas data were scaled to DWPF flow rates. The calculation methodology has been previously documented. ${ }^{14}$ An internal standard flow was established with helium. Other gas flow rates were determined relative to helium by taking the ratio of the two gas volume percentages times the helium standard flow. The results were scaled by the ratio of 6,000 gallons of fresh sludge divided by the volume of fresh sludge in the simulant SRAT charge. 


\subsection{Offgas Analysis}

For the 4-L runs, the chilled offgas leaving the FAVC was passed through a Nafion ${ }^{\circledR}$ dryer in countercurrent flow with a dried air stream to reduce the moisture content of the gases to the analyzers. The GC internal pump pulled a sample at approximately four minute intervals from this offgas line. A separate sample pump was used to transport samples from the offgas line to the MS and FTIR. Mass flow controllers were used to regulate the amount of gases sent to the MS ( $\sim 50 \mathrm{~mL} / \mathrm{min})$ and FTIR ( $150 \mathrm{~mL} / \mathrm{min})$. The FTIR sampled only one of each pair of 4-L runs (GN71, GN73, and GN75). The MS alternately sampled each stream. The total sample flow pumped from the offgas system had to be maintained below the total offgas flow from the SRAT/SME equipment so that ambient air would not be drawn into the system and give erroneous results.

For the 22-L tests, a sample pump was used to transport the FAVC exit gas sample in Lab 134 to the analyzers in Lab 132. A Nafion ${ }^{\circledR}$ dryer was installed in-line after the sample pump to reduce the moisture content. The gas chromatograph internal pump pulled a sample at approximately four minute intervals from this sample line. Mass flow controllers were used to regulate the amount of gases sent to the MS ( 60 $\mathrm{mL} / \mathrm{min}$ ) and FTIR (>200 mL/min). All three analyzers were used for both 22-L tests (GN76, GN77).

For the 220-L tests, a similar system was used to sample the offgas. A PermaPure miniGASS ${ }^{\text {TM }}$ sample conditioning system was used with a gas sampling pump. The sample conditioning system contained a Nafion ${ }^{\circledR}$ dryer similar to those used for the 4-L and 22-L runs. All three analyzers were used for both $220-\mathrm{L}$ tests (GN78, GN79).

Raw chromatographic data were acquired by the GC using separate computers interfaced to the data acquisition computer. Each experiment had a dedicated Agilent (or Inficon) 3000A dual column micro GC. Column-A can collect data related to $\mathrm{He}, \mathrm{H}_{2}, \mathrm{O}_{2}, \mathrm{~N}_{2}$, NO, and CO, while column-B can collect data related to $\mathrm{CO}_{2}, \mathrm{~N}_{2} \mathrm{O}$, and water. Data for NO, CO, and water are only qualitative. The GCs were calibrated with a standard calibration gas containing $\mathrm{He}, \mathrm{H}_{2}, \mathrm{O}_{2}, \mathrm{~N}_{2}, \mathrm{CO}_{2}$ and $\mathrm{N}_{2} \mathrm{O}$. The calibration was verified prior to starting the SRAT cycle and after completing the SME cycle. Room air was used to give a two point calibration for $\mathrm{N}_{2}$. Raw chromatographic data were acquired by the GC from the FAVC offgas stream samples using a separate computer interfaced to the data acquisition computer. Sampling frequency was approximately one chromatogram every four minutes. The chilled offgas exiting the FAVC passed through a Nafion ${ }^{\circledR}$ dryer in counter-current flow with a dried air stream to reduce the moisture content at the GC inlet. The dried, chilled offgas stream was sampled by GC from the beginning of heat-up to temperature to start the SRAT cycle through most of the cool down following the SME cycle. No evidence for CO generation was obtained while examining the region of the chromatogram where it would elute. NO was observed in all runs during nitrite destruction, but NO is not in the GC calibration gas, so only the timing of NO generation was quantitatively determined from GC data.

An Extrel CMS MAX300LG MS was used to measure $\mathrm{H}_{2}, \mathrm{He}, \mathrm{N}_{2}, \mathrm{O}_{2}, \mathrm{NO}, \mathrm{NO}_{2}, \mathrm{CO}_{2}$, and Ar. The MS is calibrated by a series of gas mixtures that are used to measure background intensity, ion fragmentation, and sensitivity. All gases used were National Institute of Standards and Technology (NIST) traceable; the certificates of analysis are documented in the SRNL Electronic Lab Notebook (ELN). In addition, qualitative intensity measurements of specific ion masses that might be expected from antifoam degradation products were also measured. HMDSO was monitored at masses 148, 147, 131, and 73; trimethylsilanol was monitored at mass 75; propylene was monitored at masses 41 and 42; and poly(ethylene)glycol (PEG) fragments were monitored at masses 58,59, and 89. Measurements of $\mathrm{H}_{2}$ by MS were somewhat inaccurate due to the extremely low values that were subject to error due to drift in the MS background signal. For some runs, the He calibration drifted and was corrected by a linear interpolation between the calibration value and the post-calibration check value. 
For the 4-L runs, the MS alternately measured the two systems. Each system was measured for about 110 sec with a 28 sec delay in between to flush out the other system's sample. The sampling rate was about one sample per 8-10 seconds. The presence of $\mathrm{N}_{2} \mathrm{O}$ in the process gas samples introduces error in the measurements of $\mathrm{CO}_{2}, \mathrm{NO}$, and $\mathrm{N}_{2}$ because it has fragment ions at the measurement masses of each of these gases. The MS cannot be calibrated for $\mathrm{N}_{2} \mathrm{O}$ because the relative amount of $\mathrm{N}_{2} \mathrm{O}$ to the other gases is too small to give a reliable calibration. The presence of $1.2 \% \mathrm{~N}_{2} \mathrm{O}$ (the highest value measured by GC) would result in the measurement of $\mathrm{N}_{2}$ being high by about $0.12 \%$, $\mathrm{NO}$ being high by about $0.24 \%$, and $\mathrm{CO}_{2}$ being high by about $0.86 \%$. An $\mathrm{N}_{2} \mathrm{O}$ calibration gas was used to determine these ratios and the $\mathrm{N}_{2}, \mathrm{NO}$, and $\mathrm{CO}_{2}$ data were adjusted post-run using the $\mathrm{N}_{2} \mathrm{O}$ measured by the GC or FTIR. When the $\mathrm{N}_{2} \mathrm{O}$ from the GC or FTIR was added to the adjusted MS data, the sum was generally within 99.9 to $100.1 \%$.

An MKS MG2030 FTIR spectrometer was used for 4-L runs GN71, GN73, and GN75, and for all of the 22$\mathrm{L}$ and 220-L runs. For the 4-L tests, the FTIR is connected to the two SRAT/SME offgas systems like the MS, but it is manually valved into one or the other for the duration of the run. The FTIR measures $\mathrm{CO}, \mathrm{CO}_{2}$, $\mathrm{NO}, \mathrm{NO}_{2}, \mathrm{~N}_{2} \mathrm{O}, \mathrm{H}_{2} \mathrm{O}$, and HMDSO concentrations. HMDSO is a volatile marker for decomposed antifoam. Although the GC detects water, the FTIR gives a quantitative concentration for moisture in the chilled offgas leaving the Nafion ${ }^{\circledR}$ drier. The FTIR obtained data roughly every 15 seconds.

\section{Sampling System Problems}

During run GN70, there was a leak between the sample pump and the mass flow controllers that resulted in dilution of the sample to the MS. In both GN70 and GN72, there was inleakage within the Nafion ${ }^{\circledR}$ dryer that resulted in additional dilution; this inleakage also affected the GC results. The Nafion ${ }^{\circledR}$ dryer was found to have cracks in the internal tubing. This tubing was replaced before run GN74. Due to the inleakage, the offgas data had to be adjusted using the He purge tracer values. The odd numbered runs were not affected by these problems.

In run GN76, the flow to the MS dropped about one hour into the SRAT dewater and was intermittent until about 16 hours. During this time, the GC and FTIR data were still being recorded. FTIR data was also not taken during about 10.5 hours near the end of the SME cycle due to loss of liquid nitrogen cooling.

\subsection{Quality Assurance}

Requirements for performing reviews of technical reports and the extent of review are established in manual E7 2.60. SRNL documents the extent and type of review using the SRNL Technical Report Design Checklist contained in WSRC-IM-2002-00011, Rev. 2.

\subsection{Results and Mass Balances}

This section provides the results primarily for the eight runs that were duplicated as part of this task to determine the impact of experimental scale on the nitric-glycolic acid flowsheet CPC processing of an SB8 sludge simulant. In order to determine the impact of scale, a number of mass balances were completed, including the overall mass balance and balances for nitrogen and carbon. In addition, analysis was performed to better understand the mercury, hydrogen, ammonia and the condensate during processing. In addition, tables, graphs, and photographs summarizing the data are included to give an overall assessment of the quality of the data and to elucidate trends. The data are simplified in tables and graphs in the report but all the data are available in the Electronic Laboratory Notebook system.

Two runs will be discussed minimally, namely GN71 and GN72. GN71 was the highest stoichiometry run (125\%) and led to slurry rheology that challenged/exceeded the DWPF rheology design basis limits for both the SRAT and SME. GN72 was one of four 100\% acid stoichiometry runs but was not repeated as the 
REDOX didn't match the intended target. For simplicity, data from runs GN71 and GN72 were left out of many of the graphs and tables. Additional data from these runs was collected and is included in the appendix or is stored in the electronic notebook. But since these runs were not duplicated at more than one scale, their results are less important than the eight runs that will be discussed.

Only one set of run conditions was duplicated at the same scale (GN73 and 75). The comparison between these runs is important as it shows the variability in completing two experiments that are planned to be identical. Comparing runs at different scales can't be expected to have less variability than two runs at the same scale.

It is difficult to completely duplicate runs at different scales. In order to scale the runs as closely as practical, an attempt was made to pull the same relative volume of samples at all scales. So much larger samples were pulled in the larger scale experiments.

The most important question to ask is "Does the nitric-glycolic acid flowsheet process chemistry change as the scale is increased from the 4-L lab-scale to the 22-L lab-scale to the 220-L pilot scale?” The answer to this question will be addressed in this section. Table 3-1 below is a quick summary to answer this question. The table below summarizes the results from the following sections and groups the "identical runs" side by side for easy. The color coding used in the table uses green for areas where the agreement within the identical runs was excellent (within $10 \%$ of each other), yellow for areas where the agreement is good (10$20 \%)$, and red for areas where the agreement was poor (>20\%). This is based on various other tables in the report with more specific criteria as summarized below each table.

Table 3-1. Overall Summary of Scaled Experiments

\begin{tabular}{|c|c|c|c|c|c|c|c|c|}
\hline $\begin{array}{l}\text { KMA Acid } \\
\text { Stoichiometry }\end{array}$ & \multicolumn{4}{|c|}{$100 \%$} & \multicolumn{4}{|c|}{$110 \%$} \\
\hline Run & GN70 & GN76 & GN74 & GN79 & GN73 & GN75 & GN77 & GN78 \\
\hline SRAT Scale & $1 / 7,541$ & $1 / 1,317$ & $1 / 7,541$ & $1 / 170$ & $1 / 7,541$ & $1 / 7,541$ & $1 / 1,443$ & $1 / 199$ \\
\hline SME Scale & $1 / 9,504$ & $1 / 1,690$ & $1 / 9,504$ & $1 / 187$ & $1 / 9,504$ & $1 / 9,504$ & $1 / 1,783$ & $1 / 222$ \\
\hline $\begin{array}{l}\text { Acid Ratio, } \\
\text { Glycolic/Total }\end{array}$ & 0.5831 & 0.5831 & 0.5454 & 0.5454 & 0.5221 & 0.5221 & 0.5221 & 0.5221 \\
\hline Process Chemist & & & & & & & & \\
\hline Rheology & & & & & & & & \\
\hline Heat Transfer & & & & & & & & \\
\hline REDOX & & & & & & & & \\
\hline Hydrogen & & & & & & & & \\
\hline
\end{tabular}

\begin{tabular}{|l|l|}
\hline & Excellent \\
\hline & Good \\
\hline & Poor \\
\hline
\end{tabular}

A comparison will be made for identical experiments completed at all three scales, which is the leading objective of this body of work. The following objectives will be evaluated as a function of scale to include:

- SRAT/SME Product Sample Analysis

- Major offgas species

- Minor offgas species 
- Nitrogen chemistry and mass balance

- Carbon chemistry and mass balance

- Mercury chemistry, mass balance, and MWWT performance

- Hydrogen Generation

- Ammonia chemistry, mass balance, and scrubber performance

- Condensate Balance

- Rheology

- REDOX

- Mixing and Heat transfer

\subsection{Flowsheet Chemistry and Acid Calculation}

Acid calculations were performed using the KMA Equation [1]. The KMA was developed for the nitricformic acid flowsheet and is not correct for the nitric-glycolic acid flowsheet. Glycolic acid is a better reducing agent than formic acid. Glycolic acid provides three times the reducing power per mole of acid than formic. As a result, a glycolic minimum acid equation has been developed. For the acid base and carbonate reactions, the acid factor is the same for all the acid equations. For the reduction reactions, onethird of the KMA factor was used. All of the stoichiometric factors are summarized in Table 3-2. The result is the acid demand for the glycolic acid flowsheet is 83\% of the KMA for the SB8 sludge simulant used in this study. Note that the GMA Equation [3] requires validation.

The KMA Equation [1] was used in all acid calculation spreadsheets for this study. Testing was completed at $100 \%, 110 \%$ and $125 \%$ of KMA. This is equivalent to $107 \%, 117 \%$ and $134 \%$ respectively for the Hsu acid equation or 120\%, 132\%, and 151\% for the Glycolic Minimum Acid (GMA) Equation [3].

So for the reduction reactions, the stoichiometric factor for glycolic acid is one-third of that for formic acid. For the acid/base reactions, one mole of formic acid is equivalent to one mole of glycolic acid. As a result, the moles of acid needed for glycolic/nitric acid flowsheet is about 0.83 times the moles for the nitricformic acid flowsheet. The acid factors used in the three acid equations are summarized in Table 3-2. A more complete discussion of the development of the GMA model can be found in the report on DWPF Nitric-Glycolic Flowsheet Chemical Process Cell Chemistry: Part 1. ${ }^{11}$

Table 3-2. Stoichiometric Acid Factors Used in Acid Equations

\begin{tabular}{|c|c|c|c|c|}
\hline Acid Base Reactions & Hsu & KMA & GMA & Units \\
\hline Acid requirement per mole of hydroxide & 1.00 & 1.00 & 1.00 & mole $\mathrm{H}^{+}$/ mole $\mathrm{OH}-$ \\
\hline Acid requirement per mole of carbonate & $2.00 *$ & $1.00 \#$ & $1.00 \#$ & mole $\mathrm{H}^{+}$/ mole $\mathrm{CO}_{3}{ }^{2}$ \\
\hline Acid requirement per mole of calcium & 0.00 & 1.50 & 1.50 & mole $\mathrm{H}^{+} /$mole $\mathrm{Ca}$ \\
\hline Acid requirement per mole of magnesium & 0.00 & 1.50 & 1.50 & mole $\mathrm{H}^{+} /$mole $\mathrm{Mg}$ \\
\hline \multicolumn{5}{|l|}{ Reduction Reactions } \\
\hline Acid requirement per mole of nitrite & 0.75 & 1.00 & 0.75 & mole $\mathrm{H}^{+}$/ mole $\mathrm{NO}_{2}$ \\
\hline Acid requirement per mole of mercury & 1.00 & 1.00 & 0.33 & mole $\mathrm{H}^{+} /$mole $\mathrm{Hg}^{++}$ \\
\hline Acid requirement per mole of manganese & 1.20 & 1.50 & 0.80 & mole $\mathrm{H}^{+}$/ mole $\mathrm{Mn}$ \\
\hline Total Acid Requirement & 1.27 & 1.36 & 0.988 & mole $\mathrm{H}+/ \mathrm{L}$ sludge \\
\hline
\end{tabular}

* Total Carbonate

\# Soluble Carbonate

\subsection{Overall Mass Balance and Process Times}

Before discussing the component mass balances, it is important to ensure that the runs were completed as planned, the right masses of reagents were added, the correct reagent flowrates and boilup rates and dewater quantities were used, and the same temperature profile (time at temperature) was accomplished. 
As can be seen in Table 3-3, the sludge mass, acid mass, SRAT dewater mass, frit/water mass and SME dewater mass were all as planned by the R\&D instructions. The total solids of the SRAT products varied from 27.26 to 28.30 with a target of $27 \mathrm{wt} \%$ total solids. The total solids of the SME products varied from 45.43 to 49.67 with a target of $45 \mathrm{wt} \%$ total solids. The acid addition time varied from 2.9 to 3.1 hours. The total boiling time varied from 68.1 to 74.8 hours with the $220-\mathrm{L}$ experiments having the longest time likely due to measurement error in estimating the steam condensate.

The only deviation from plan is that run GN76 is a duplicate of run GN70 instead of GN74. This means the REDOX ratio for runs GN70 and GN76 is slightly higher than runs GN70 and GN79. So in the tables, the two sets of identical runs will be side by side for simpler comparison. It should also be noted that runs GN73 and GN75 are essentially duplicate 4-L runs. Any deviation between these two is likely just the random differences in two identical runs. Any duplication of a run at a different scale would likely have a larger delta than these identical runs.

Table 3-3. Overall Mass Balance and Processing Time Summary

\begin{tabular}{|c|c|c|c|c|c|c|c|c|}
\hline Acid Stoichiometry & & 10 & & & & & & \\
\hline Run & GN70 & GN76 & GN74 & GN79 & GN73 & GN75 & GN77 & GN78 \\
\hline $\begin{array}{l}\text { Acid Ratio, } \\
\text { Glycolic:Total }\end{array}$ & 0.5831 & 0.5831 & 0.5454 & 0.5454 & 0.5221 & 0.5221 & 0.5221 & 0.5221 \\
\hline $\begin{array}{l}\text { Chemical additions } \\
\text { equivalent }\end{array}$ & Yes & Yes & Yes & Yes & Yes & Yes & Yes & Yes \\
\hline $\begin{array}{l}\text { SRAT product total } \\
\text { solids }\end{array}$ & 28.30 & 27.26 & 28.03 & 27.65 & 27.60 & 28.04 & 27.97 & 27.65 \\
\hline SME product total solids & 49.49 & 45.55 & 47.11 & 45.43 & 46.55 & 45.98 & 45.91 & 49.67 \\
\hline Acids addition time & 3.1 & 3.0 & 2.9 & 2.9 & 3.1 & 3.1 & 3.0 & 3.0 \\
\hline SRAT Boiling Time & 43.8 & 43.8 & 43.8 & 43.8 & 43.3 & 43.3 & 43.3 & 43.3 \\
\hline Total SME Boiling Time & 27.9 & 29.1 & 24.3 & 31.0 & 26.5 & 25.5 & 29.4 & 29.5 \\
\hline Total Boiling Time & 71.7 & 72.9 & 68.1 & 74.8 & 69.8 & 68.8 & 72.7 & 72.8 \\
\hline
\end{tabular}

Note: The color shading used in the above table is shown below (green is excellent, yellow is good, red is unacceptable)

\begin{tabular}{|l|l|}
\hline & $+/-2 \mathrm{wt} \%,+/-5 \%$ for times \\
\hline & $+/-4 \mathrm{wt} \%,+/-10 \%$ for times \\
\hline & $+/-10 \mathrm{wt} \%,+/-25 \%$ for times \\
\hline
\end{tabular}

\subsubsection{SRAT and SME Product}

The SRAT and SME products were analyzed by PSAL for solids, $\mathrm{pH}$ and density. The results are reported in Table 3-4 and Table 3-5. The $\mathrm{pH}$ of the products was approximately 7 for the $100 \%$ stoichiometry runs, 5 for the 110\% stoichiometry runs and 4 for the 125\% stoichiometry run (GN71-125). In addition, the soluble solids and supernate density are higher for the higher acid stoichiometry runs as more metals are dissolved. In the runs, a SRAT product of $27 \mathrm{wt} \%$ total solids and a SME product of $45 \mathrm{wt} \%$ solids were targeted. 
Table 3-4. SRAT Product Solids, pH, Density

\begin{tabular}{|l|c|c|c|c|c|c|c|c||}
\hline Run & $\begin{array}{c}\text { Total } \\
\text { Solids, } \\
\text { wt \% }\end{array}$ & $\begin{array}{c}\text { Insoluble } \\
\text { Solids, } \\
\text { wt \% }\end{array}$ & $\begin{array}{c}\text { Calcined } \\
\text { Solids, } \\
\text { wt \% }\end{array}$ & $\begin{array}{c}\text { Soluble } \\
\text { Solids, } \\
\text { wt \% }\end{array}$ & $\begin{array}{c}\text { Supernate } \\
\text { Solids, } \\
\text { wt \% }\end{array}$ & $\mathbf{p H}$ & $\begin{array}{c}\text { Slurry } \\
\text { Density, } \\
\mathbf{g} / \mathbf{m L}\end{array}$ & $\begin{array}{c}\text { Supernate } \\
\text { Density, } \\
\text { g/mL }\end{array}$ \\
\hline GN70-100 & 28.27 & 12.89 & 16.02 & 15.38 & 17.66 & 7.08 & 1.22 & 1.12 \\
\hline GN76-100 & 27.26 & 11.74 & 15.73 & 15.52 & 17.58 & 7.60 & 1.21 & 1.11 \\
\hline GN74-100 & 28.03 & 12.77 & 16.01 & 15.26 & 17.50 & 7.07 & 1.22 & 1.12 \\
\hline GN79-100 & 27.63 & 12.99 & 16.02 & 14.64 & 16.82 & 7.04 & 1.21 & 1.11 \\
\hline GN73-110 & 27.60 & 10.81 & 15.10 & 16.79 & 18.83 & 4.46 & 1.22 & 1.13 \\
\hline GN75-110 & 28.04 & 11.58 & 15.30 & 16.46 & 18.62 & 4.33 & 1.22 & 1.13 \\
\hline GN77-110 & 27.97 & 11.97 & 15.35 & 16.00 & 18.18 & 4.80 & 1.21 & 1.14 \\
\hline GN78-110 & 27.65 & 12.04 & 15.31 & 15.61 & 17.75 & 5.10 & 1.21 & 1.13 \\
\hline GN71-125 & 25.95 & 9.80 & 13.28 & 16.16 & 17.91 & 3.79 & 1.19 & 1.13 \\
\hline GN72-100 & 28.40 & 13.20 & 16.32 & 15.20 & 17.51 & 7.15 & 1.22 & 1.12 \\
\hline
\end{tabular}

Table 3-5. SME Product Solids, pH, Density

\begin{tabular}{|l|c|c|c|c|c|c|c|c||}
\hline Run & $\begin{array}{c}\text { Total } \\
\text { Solids, } \\
\text { wt \% }\end{array}$ & $\begin{array}{c}\text { Insoluble } \\
\text { Solids, } \\
\text { wt \% }\end{array}$ & $\begin{array}{c}\text { Calcined } \\
\text { Solids, } \\
\text { wt \% }\end{array}$ & $\begin{array}{c}\text { Soluble } \\
\text { Solids, } \\
\text { wt \% }\end{array}$ & $\begin{array}{c}\text { Supernate } \\
\text { Solids, } \\
\text { wt \% }\end{array}$ & pH & $\begin{array}{c}\text { Slurry } \\
\text { Density, } \\
\text { g/mL }\end{array}$ & $\begin{array}{c}\text { Supernate } \\
\text { Density, } \\
\text { g/mL }\end{array}$ \\
\hline GN70-100 & 49.30 & 36.72 & 39.20 & 12.58 & 19.88 & 7.15 & 1.42 & 1.13 \\
\hline GN76-100 & 45.55 & 32.92 & 35.78 & 12.64 & 18.83 & 7.96 & 1.37 & 1.12 \\
\hline GN74-100 & 47.11 & 33.90 & 36.97 & 13.20 & 19.98 & 7.08 & 1.40 & 1.13 \\
\hline GN79-100 & 45.43 & 33.59 & 35.59 & 11.84 & 17.83 & 7.18 & 1.26 & 1.12 \\
\hline GN73-110 & 46.55 & 33.14 & 35.77 & 13.41 & 20.06 & 4.82 & 1.38 & 1.15 \\
\hline GN75-110 & 45.98 & 32.00 & 34.99 & 13.98 & 20.56 & 4.78 & 1.38 & 1.14 \\
\hline GN77-110 & 45.91 & 32.38 & 35.13 & 13.53 & 20.00 & 5.75 & 1.39 & 1.14 \\
\hline GN78-110 & 49.67 & 37.23 & 39.46 & 12.44 & 19.82 & 5.55 & 1.40 & 1.15 \\
\hline GN71-125 & 44.44 & 30.71 & 33.31 & 13.73 & 19.81 & 3.91 & 1.36 & 1.14 \\
\hline GN72-100 & 46.82 & 32.62 & 36.41 & 14.19 & 21.06 & 7.30 & 1.37 & 1.14 \\
\hline
\end{tabular}

Note: Red numbers are unusually high or low. The GN70 and 78 total solids are significantly higher than targeted. The GN79 slurry density is lower than expected.

The SRAT and SME products (both slurry and filtrate) were analyzed by PSAL by ICP-AES for metals. SRAT product results are reported in Table 3-6, and Table 3-7. No insoluble form of Na, K, or S was added in SB8 simulant development. As a result, in the SRAT product, $\mathrm{Na}, \mathrm{K}$, and $\mathrm{S}$ are expected to be completely soluble (expected solubility $80-120 \%$ because of analytical uncertainty). Note that the elemental percent in the filtrate was above $120 \%$ in some of the runs for $\mathrm{S}$, due to analytical error or uncertainty in the slurry or filtrate analysis. In addition, $\mathrm{Ca}, \mathrm{Mg}$, and $\mathrm{Mn}$ are largely soluble. Note the solubility for these three increases with acid stoichiometry. In addition, metals such as $\mathrm{Cu}, \mathrm{Li}, \mathrm{Ni}$ and $\mathrm{Zn}$ have significant solubilities at $100 \%$ acid stoichiometry. This explains the higher soluble solids and supernate density results for the higher acid stoichiometry runs as more metals are dissolved. SME product results are reported in Table 3-8, and Table 3-9. In the SME product, Na is no longer completely soluble as sodium in added in the insoluble frit additions. Sodium did not precipitate out during processing. K and S are expected to be completely soluble (expected solubility $80-120 \%$ because of analytical uncertainty). Again, the elemental percent in the filtrate in some runs was above $120 \%$ for S, due to an error in the slurry or filtrate analysis. In addition, $\mathrm{Ca}, \mathrm{Mg}$, and $\mathrm{Mn}$ are all mostly soluble. Note the solubility for these three increases with acid stoichiometry. It also should be noted that many of the metals have a lower solubility in the SME product than the SRAT product. 
Table 3-6. SRAT Product Analyses

\begin{tabular}{|c|c|c|c|c|c|c|c|c|c|}
\hline \multicolumn{10}{|c|}{ SRAT Product Slurry Cations, wt \% calcined solids } \\
\hline Run & $\begin{array}{c}\text { GN70- } \\
100\end{array}$ & $\begin{array}{c}\text { GN76- } \\
100\end{array}$ & $\begin{array}{c}\text { GN74- } \\
100\end{array}$ & $\begin{array}{c}\text { GN79- } \\
100\end{array}$ & $\begin{array}{c}\text { GN71- } \\
125 \\
\end{array}$ & $\begin{array}{c}\text { GN73- } \\
110\end{array}$ & $\begin{array}{c}\text { GN75- } \\
110\end{array}$ & $\begin{array}{c}\text { GN77- } \\
110 \\
\end{array}$ & $\begin{array}{c}\text { GN78- } \\
110 \\
\end{array}$ \\
\hline $\mathrm{Al}$ & 10.0 & 10.3 & 10.5 & 9.05 & 10.2 & 9.57 & 10.3 & 9.85 & 10.1 \\
\hline $\mathrm{Ba}$ & 0.150 & 0.154 & 0.154 & 0.157 & 0.150 & 0.157 & 0.156 & 0.152 & 0.162 \\
\hline $\mathrm{Ca}$ & 1.67 & 1.54 & 1.55 & 1.82 & 1.60 & 1.59 & 1.54 & 1.52 & 1.53 \\
\hline $\mathrm{Cr}$ & 0.091 & 0.098 & 0.092 & 0.102 & 0.094 & 0.097 & 0.094 & 0.098 & 0.121 \\
\hline $\mathrm{Cu}$ & 0.055 & 0.059 & 0.052 & 0.100 & 0.056 & 0.100 & 0.054 & 0.071 & 0.100 \\
\hline $\mathrm{Fe}$ & 24.6 & 23.0 & 24.5 & 21.6 & 24.0 & 22.5 & 25.0 & 23.4 & 23.9 \\
\hline $\mathrm{K}$ & 0.196 & 0.147 & 0.161 & 0.155 & 0.159 & 0.165 & 0.179 & 0.141 & 0.169 \\
\hline $\mathrm{Mg}$ & 0.301 & 0.306 & 0.301 & 0.314 & 0.298 & 0.318 & 0.304 & 0.305 & 0.326 \\
\hline $\mathrm{Mn}$ & 7.48 & 7.12 & 7.67 & 6.88 & 7.40 & 7.85 & 7.70 & 6.95 & 7.50 \\
\hline $\mathrm{Na}$ & 17.5 & 17.1 & 16.3 & 15.9 & 17.9 & 17.7 & 16.2 & 16.7 & 16.3 \\
\hline $\mathrm{Ni}$ & 2.41 & 2.24 & 2.35 & 2.22 & 2.30 & 2.46 & 2.40 & 1.96 & 2.35 \\
\hline$S$ & 0.381 & 0.403 & 0.390 & 0.416 & 0.376 & 0.413 & 0.398 & 0.380 & 0.420 \\
\hline $\mathrm{Si}$ & 1.64 & 1.35 & 1.43 & 3.27 & 1.58 & 1.77 & 1.40 & 1.58 & 1.66 \\
\hline $\mathrm{Zr}$ & 0.231 & 0.182 & 0.188 & 0.191 & 0.227 & 0.174 & 0.185 & 0.189 & 0.215 \\
\hline \multicolumn{10}{|c|}{ SRAT Product Supernate Cations, mg/kg slurry } \\
\hline $\mathrm{Al}$ & 224 & 190 & 156 & 156 & 1069 & 483 & 402 & 175 & 39.2 \\
\hline Ва & 0.668 & $<0.792$ & 0.418 & $<0.754$ & 2.68 & 1.04 & 1.13 & 0.208 & $<0.778$ \\
\hline $\mathrm{Ca}$ & 1,380 & 1,150 & 1,300 & 1,390 & 2,080 & 1,870 & 1,870 & 1,520 & 1,760 \\
\hline $\mathrm{Cr}$ & 0.525 & 0.220 & 0.486 & 0.631 & 4.67 & 2.25 & 2.25 & 0.948 & 1.42 \\
\hline $\mathrm{Cu}$ & 2.36 & 1.19 & 0.88 & 0.90 & 39.8 & 27.6 & 24.0 & 21.5 & 7.66 \\
\hline $\mathrm{Fe}$ & 20.5 & 23.1 & 14.9 & 18.9 & 3,540 & 511 & 635 & 153 & 35.1 \\
\hline K & 385 & 345 & 355 & 434 & 276 & 337 & 382 & 299 & 306 \\
\hline $\mathrm{Mg}$ & 318 & 387 & 382 & 446 & 340 & 418 & 396 & 386 & 418 \\
\hline Mn & 9,100 & 7,300 & 8,930 & 10,100 & 9,060 & 10,500 & 10,300 & 9,330 & 11,100 \\
\hline $\mathrm{Na}$ & 27,600 & 28,800 & 26,500 & 30,200 & 24,100 & 27,000 & 25,800 & 24,600 & 27,200 \\
\hline $\mathrm{Ni}$ & 70.7 & 28.0 & 382 & 60.1 & 2,260 & 1,110 & 1,050 & 890 & 826 \\
\hline$S$ & 704 & 694 & 665 & 824 & 612 & 710 & 661 & 631 & 651 \\
\hline $\mathrm{Si}$ & 24.3 & 36.7 & 38.0 & 46.0 & 222 & 132 & 125 & 93.5 & 73.2 \\
\hline Sn & 5.29 & 4.67 & 5.48 & 4.38 & 6.34 & 7.15 & 6.80 & 6.18 & 6.90 \\
\hline $\mathrm{Ti}$ & $<0.078$ & $<0.079$ & $<0.078$ & $<0.090$ & 4.55 & 0.820 & $<0.709$ & 0.341 & $<0.078$ \\
\hline $\mathrm{Zn}$ & 0.152 & $<0.079$ & $<0.078$ & 0.177 & 29.1 & 13.8 & 13.0 & 15.6 & 7.07 \\
\hline $\mathrm{Zr}$ & $<0.781$ & $<0.079$ & $<0.781$ & $<0.090$ & $<0.801$ & $<0.790$ & $<0.784$ & $<0.077$ & $<0.078$ \\
\hline
\end{tabular}


Table 3-7. SRAT Product \% of Element Soluble in Slurry

\begin{tabular}{|c|c|c|c|c|c|c|c|c|c|}
\hline Run & $\begin{array}{c}\text { GN70- } \\
100\end{array}$ & $\begin{array}{c}\text { GN76- } \\
100\end{array}$ & $\begin{array}{c}\text { GN74- } \\
100\end{array}$ & $\begin{array}{c}\text { GN79- } \\
100\end{array}$ & $\begin{array}{c}\text { GN71- } \\
125\end{array}$ & $\begin{array}{c}\text { GN73- } \\
110\end{array}$ & $\begin{array}{c}\text { GN75- } \\
110\end{array}$ & $\begin{array}{c}\text { GN77- } \\
110\end{array}$ & $\begin{array}{c}\text { GN78- } \\
110\end{array}$ \\
\hline $\mathrm{Al}$ & 1.40 & 1.18 & 0.926 & 1.08 & 7.88 & 3.35 & 2.56 & 1.15 & 0.254 \\
\hline $\mathrm{Ba}$ & 0.278 & 0.328 & 0.169 & 0.300 & 1.34 & 0.439 & 0.473 & 0.089 & 0.313 \\
\hline $\mathrm{Ca}$ & 51.4 & 47.6 & 52.4 & 47.7 & 97.8 & 78.5 & 79.1 & 65.1 & 75.2 \\
\hline $\mathrm{Cr}$ & 0.360 & 0.144 & 0.330 & 0.384 & 3.73 & 1.56 & 1.56 & 0.631 & 0.769 \\
\hline $\mathrm{Cu}$ & 2.66 & 1.28 & 1.04 & 0.560 & 53.7 & 18.3 & 29.1 & 19.8 & 5.00 \\
\hline $\mathrm{Fe}$ & 0.052 & 0.064 & 0.038 & 0.055 & 11.1 & 1.51 & 1.66 & 0.426 & 0.096 \\
\hline $\mathrm{K}$ & 123 & 150 & 138 & 175 & 130 & 136 & 139 & 138 & 118 \\
\hline $\mathrm{Mg}$ & 66.0 & 80.5 & 79.3 & 88.6 & 85.9 & 87.0 & 85.2 & 82.3 & 83.6 \\
\hline $\mathrm{Mn}$ & 75.9 & 65.2 & 72.8 & 92.1 & 92.2 & 88.9 & 87.6 & 87.4 & 96.3 \\
\hline $\mathrm{Na}$ & 98.4 & 107 & 102 & 118 & 102 & 101 & 104 & 95.5 & 109 \\
\hline $\mathrm{Ni}$ & 1.83 & 0.795 & 1.50 & 1.69 & 74.0 & 29.8 & 28.6 & 29.7 & 22.9 \\
\hline$S$ & 115 & 110 & 106 & 124 & 123 & 114 & 108 & 108 & 101 \\
\hline $\mathrm{Si}$ & 0.929 & 1.73 & 1.66 & 0.877 & 10.6 & 4.93 & 5.83 & 3.87 & 2.88 \\
\hline Sn & 3.30 & 2.97 & 3.42 & 2.74 & 4.77 & 4.73 & 4.44 & 4.03 & $<4.50$ \\
\hline $\mathrm{Ti}$ & $<0.049$ & $<0.050$ & $<0.049$ & $<0.056$ & 3.42 & 0.543 & 0.463 & 0.222 & $<0.051$ \\
\hline $\mathrm{Zn}$ & 0.095 & $<0.050$ & $<0.026$ & 0.111 & 21.9 & 9.16 & 4.58 & 10.1 & 4.61 \\
\hline
\end{tabular}

Table 3-8. SME Product \% of Element Soluble in Slurry

\begin{tabular}{|c|c|c|c|c|c|c|c|c|c|}
\hline Run & $\begin{array}{c}\text { GN70- } \\
100 \\
\end{array}$ & $\begin{array}{c}\text { GN76- } \\
100 \\
\end{array}$ & $\begin{array}{c}\text { GN74- } \\
100\end{array}$ & $\begin{array}{c}\text { GN79- } \\
100\end{array}$ & $\begin{array}{c}\text { GN71- } \\
125\end{array}$ & $\begin{array}{c}\text { GN73- } \\
110\end{array}$ & $\begin{array}{c}\text { GN75- } \\
110 \\
\end{array}$ & $\begin{array}{c}\text { GN77- } \\
110\end{array}$ & $\begin{array}{c}\text { GN78- } \\
110\end{array}$ \\
\hline $\mathrm{Al}$ & 0.99 & 0.76 & 0.854 & 0.81 & 3.82 & 1.75 & 1.05 & 0.61 & 0.44 \\
\hline $\mathrm{B}$ & 0.262 & 0.284 & 0.269 & 0.146 & 0.877 & 0.798 & 0.785 & 0.569 & 0.037 \\
\hline $\mathrm{Ba}$ & 0.279 & 0.486 & 0.093 & 0.167 & 1.54 & 0.312 & 0.365 & 0.193 & 0.139 \\
\hline $\mathrm{Ca}$ & 61.6 & 47.0 & 53.5 & 53.1 & 106 & 80.0 & $\begin{array}{l}67.7 \\
\end{array}$ & 68.6 & 74.9 \\
\hline $\mathrm{Cr}$ & 0.234 & 0.088 & 0.251 & 0.146 & 3.11 & 1.06 & 0.95 & 0.270 & 0.523 \\
\hline $\mathrm{Cu}$ & 0.935 & 0.966 & 0.597 & 0.167 & 23.6 & 15.8 & 14.6 & 0.93 & 1.15 \\
\hline $\mathrm{Fe}$ & 0.062 & 0.048 & 0.047 & 0.049 & 10.2 & 0.91 & 0.69 & 0.182 & 0.111 \\
\hline $\mathrm{K}$ & 76.4 & 84.9 & 88.6 & 70.0 & 71.8 & 83.6 & 92.0 & 85.6 & 54.6 \\
\hline $\mathrm{Li}$ & 1.37 & 1.97 & 1.66 & 1.33 & 2.03 & 2.03 & 2.05 & 2.24 & 0.162 \\
\hline $\mathrm{Mg}$ & 68.3 & 73.8 & 87.4 & 65.2 & 80.3 & 90.5 & 91.1 & 83.9 & 72.3 \\
\hline $\mathrm{Mn}$ & 70.5 & 55.1 & 68.3 & $\begin{array}{l}73.4 \\
\end{array}$ & 77.5 & 89.9 & 88.1 & 86.9 & 95.2 \\
\hline $\mathrm{Na}$ & 60.5 & 66.0 & 67.8 & 62.2 & 61.5 & 66.4 & 68.9 & 66.6 & 61.5 \\
\hline $\mathrm{Ni}$ & 1.60 & 0.363 & 1.13 & 0.89 & 80.6 & 43.7 & 42.1 & 31.6 & 19.2 \\
\hline Si & 0.023 & 0.043 & 0.043 & 0.052 & 0.257 & 0.128 & 0.126 & 0.068 & 0.057 \\
\hline Sn & NA & 7.04 & NA & NA & NA & 1.59 & NA & NA & NA \\
\hline $\mathrm{Ti}$ & NA & NA & NA & NA & NA & 0.196 & NA & NA & NA \\
\hline $\mathrm{Zn}$ & NA & NA & NA & NA & NA & 3.64 & NA & NA & NA \\
\hline
\end{tabular}


Table 3-9. SME Product Analyses

\begin{tabular}{|c|c|c|c|c|c|c|c|c|c|}
\hline \multicolumn{10}{|c|}{ SME Product Slurry Cations, wt \% calcined solids } \\
\hline Run & $\begin{array}{c}\text { GN70- } \\
100\end{array}$ & $\begin{array}{c}\text { GN76- } \\
100\end{array}$ & $\begin{array}{c}\text { GN74- } \\
100\end{array}$ & $\begin{array}{c}\text { GN79- } \\
100\end{array}$ & $\begin{array}{c}\text { GN71- } \\
125\end{array}$ & $\begin{array}{c}\text { GN73- } \\
110\end{array}$ & $\begin{array}{c}\text { GN75- } \\
110\end{array}$ & $\begin{array}{c}\text { GN77- } \\
110\end{array}$ & $\begin{array}{c}\text { GN78- } \\
110\end{array}$ \\
\hline $\mathrm{Al}$ & 3.47 & 3.93 & 3.83 & 3.78 & 3.68 & 3.41 & 3.88 & 3.81 & 3.72 \\
\hline B & 1.46 & 0.883 & 1.53 & 1.51 & 1.36 & 1.52 & 1.48 & 1.58 & 1.54 \\
\hline $\mathrm{Ba}$ & 0.048 & 0.058 & $<0.100$ & $<0.100$ & 0.053 & $<0.100$ & $<0.100$ & 0.057 & $<0.100$ \\
\hline $\mathrm{Ca}$ & 0.433 & 0.495 & 0.544 & 0.475 & 0.486 & 0.467 & 0.578 & 0.476 & 0.428 \\
\hline $\mathrm{Cr}$ & 0.035 & 0.047 & 0.039 & 0.058 & 0.038 & 0.040 & 0.040 & 0.045 & 0.045 \\
\hline $\mathrm{Cu}$ & 0.041 & 0.035 & 0.040 & $<0.100$ & 0.043 & 0.037 & 0.035 & 0.256 & $<0.100$ \\
\hline $\mathrm{Fe}$ & 7.43 & 8.57 & 8.59 & 8.36 & 7.92 & 8.84 & 9.03 & 8.31 & 7.37 \\
\hline $\mathrm{K}$ & 0.105 & 0.090 & 0.095 & 0.127 & 0.102 & 0.100 & 0.106 & 0.083 & 0.114 \\
\hline $\mathrm{Li}$ & 2.49 & 2.12 & 2.36 & 1.77 & 2.37 & 2.38 & 2.32 & 2.25 & 2.25 \\
\hline $\mathrm{Mg}$ & 0.095 & 0.119 & 0.104 & 0.140 & 0.106 & 0.110 & 0.108 & 0.116 & 0.118 \\
\hline $\mathrm{Mn}$ & 2.45 & 2.64 & 2.78 & 2.60 & 2.68 & 2.66 & 2.76 & 2.67 & 2.26 \\
\hline $\mathrm{Na}$ & 9.64 & 9.82 & 9.48 & 9.63 & 10.0 & 10.1 & 9.59 & 9.53 & 8.85 \\
\hline $\mathrm{Ni}$ & 0.588 & 0.747 & 0.693 & 0.753 & 0.660 & 0.700 & 0.716 & 0.707 & 0.663 \\
\hline$S$ & 0.117 & 0.145 & 0.121 & 0.128 & 0.126 & 0.127 & 0.128 & 0.103 & $<0.100$ \\
\hline $\mathrm{Si}$ & 25.6 & 23.8 & 24.4 & 24.4 & 24.1 & 23.3 & 23.7 & 23.5 & $<0.100$ \\
\hline Sn & $<0.100$ & 2.26 & $<0.100$ & $<0.100$ & $<0.100$ & $<0.100$ & $<0.100$ & $<0.100$ & 0.130 \\
\hline $\mathrm{Ti}$ & $<0.100$ & $<0.100$ & $<0.100$ & $<0.100$ & $<0.100$ & $<0.100$ & $<0.100$ & $<0.100$ & 25.7 \\
\hline Zn & $<0.100$ & $<0.100$ & $<0.100$ & $<0.100$ & $<0.100$ & $<0.100$ & $<0.100$ & $<0.100$ & $<0.100$ \\
\hline $\mathrm{Zr}$ & $<0.100$ & $<0.100$ & $<0.100$ & 0.184 & $<0.100$ & $<0.100$ & $<0.100$ & 0.097 & $<0.100$ \\
\hline \multicolumn{10}{|c|}{ SME Product Supernate Cations, mg/kg slurry } \\
\hline $\mathrm{Al}$ & 135 & 107 & 121 & 108 & 467 & 214 & 142 & 81.4 & 64.8 \\
\hline B & 15.0 & 8.98 & 15.2 & 7.86 & 39.7 & 43.5 & 40.6 & 31.5 & 2.26 \\
\hline $\mathrm{Ba}$ & $<0.523$ & $<0.598$ & $<0.343$ & $<0.593$ & 2.70 & 1.12 & 1.28 & $<0.388$ & $<0.547$ \\
\hline $\mathrm{Ca}$ & 1,050 & 830 & 1,070 & 900 & 1,720 & 1,340 & 1,370 & 1,150 & 1,260 \\
\hline $\mathrm{Cr}$ & 0.323 & 0.148 & 0.360 & 0.301 & 3.96 & 1.51 & 1.34 & 0.423 & 0.94 \\
\hline $\mathrm{Cu}$ & 1.52 & 1.22 & 0.874 & 0.593 & 33.5 & 21.1 & 18.0 & 8.34 & 4.55 \\
\hline $\mathrm{Fe}$ & 18.0 & 14.6 & 14.8 & 14.6 & 2,680 & 286 & 217 & 53.1 & 32.4 \\
\hline $\mathrm{K}$ & 316 & 273 & 313 & 316 & 244 & 300 & 342 & 249 & 246 \\
\hline $\mathrm{Li}$ & 133 & 149 & 144 & 84.2 & 160 & 173 & 166 & 177 & 14.4 \\
\hline $\mathrm{Mg}$ & 254 & 314 & 337 & 325 & 283 & 354 & 345 & 342 & 336 \\
\hline $\mathrm{Mn}$ & 6,760 & 5,210 & 7,030 & 6,790 & 6,920 & 8,550 & 8,510 & 8,150 & 8,480 \\
\hline $\mathrm{Na}$ & 22,900 & 23,200 & 23,700 & 21,300 & 20,500 & 23,900 & 23,100 & 22,300 & 21,500 \\
\hline $\mathrm{Ni}$ & 36.8 & 9.72 & 29.1 & 23.8 & 1,770 & 1,090 & 1,060 & 785 & 502 \\
\hline $\mathrm{P}$ & $<5.59$ & $<5.98$ & $<5.83$ & $<5.93$ & 13.3 & $<5.83$ & $<5.96$ & $<5.95$ & $<5.47$ \\
\hline $\mathrm{Pd}$ & $<0.559$ & $<0.598$ & $<0.593$ & $<0.593$ & $<0.607$ & $<0.583$ & $<0.596$ & $<0.595$ & $<0.547$ \\
\hline $\mathrm{Rh}$ & 9.6 & 6.41 & 8.22 & 6.35 & 27.9 & 21.4 & 19.6 & 15.8 & 1.57 \\
\hline $\mathrm{Ru}$ & 57.7 & 33.5 & 49.3 & 42.0 & 117 & 118 & 108 & 97.8 & 10.1 \\
\hline $\mathrm{S}$ & 581 & 569 & 596 & 604 & 533 & 618 & 586 & 567 & 544 \\
\hline $\mathrm{Si}$ & 23.2 & 36.7 & 38.4 & 45.4 & 206 & 106 & 104 & 55.8 & 57.7 \\
\hline Sn & 3.97 & 3.32 & 4.33 & 2.95 & 5.09 & 5.68 & 5.38 & 4.96 & 5.54 \\
\hline $\mathrm{Ti}$ & $<0.056$ & $<0.060$ & $<0.058$ & $<0.059$ & 3.740 & $<0.700$ & $<0.520$ & $<0.059$ & $<0.055$ \\
\hline Zn & $<0.056$ & $<0.060$ & $<0.058$ & $<0.059$ & 25.2 & 13.0 & 12.0 & 10.8 & 4.00 \\
\hline $\mathrm{Zr}$ & 0.559 & $<0.060$ & $<0.583$ & $<0.059$ & $<0.607$ & $<0.583$ & $<0.596$ & $<0.059$ & $<0.055$ \\
\hline
\end{tabular}


SRAT product and SME product anions were analyzed by PSAL for IC and are reported in Table 3-10 and Table 3-11. The slurry samples were reanalyzed using the recently developed caustic quench method, ${ }^{20}$ which improves the analysis for glycolate, oxalate and formate. Note also that almost all of the chloride was added with the $\mathrm{RuCl}_{3}$ and is much higher than targeted. Nitrite was completely destroyed in the SRAT cycle and was $<100 \mathrm{mg} / \mathrm{kg}$ in slurry and $<100 \mathrm{mg} / \mathrm{L}$ in supernate for all runs. The nitrate, glycolate, chloride, and sulfate are essentially completely soluble. Oxalate and formate solubility varies considerably across all of the runs. Fluoride and phosphate were below detection limits for all runs.

Table 3-10. SRAT Product Anions

\begin{tabular}{|c|c|c|c|c|c|c|c|c|c|}
\hline \multicolumn{10}{|c|}{ SRAT Product Slurry Anions, mg/kg } \\
\hline Run & $\mathrm{Cl}^{-}$ & $\mathrm{F}^{-}$ & $\mathrm{NO}_{2}^{-}$ & $\mathrm{NO}_{3}^{-}$ & $\mathrm{PO}_{4}^{3-}$ & $\mathrm{SO}_{4}{ }^{2-}$ & $\mathrm{C}_{2} \mathrm{H}_{3} \mathrm{O}_{3}^{-}$ & $\mathrm{C}_{2} \mathrm{O}_{4}{ }^{2-}$ & $\mathrm{CO}_{2} \mathrm{H}$ \\
\hline GN70-100 & 565 & $<100$ & $<100$ & 51,100 & $<100$ & 1,800 & 51,500 & 3,440 & 849 \\
\hline GN76-100 & 602 & $<100$ & $<100$ & 49,200 & $<100$ & 1,710 & 50,500 & 3,860 & 1,050 \\
\hline GN74-100 & 613 & $<100$ & $<100$ & 55,900 & $<100$ & 1,750 & 46,200 & 2,360 & 571 \\
\hline GN79-100 & 503 & NM & $<500$ & 52,500 & NM & 1,870 & 48,100 & 3,450 & 313 \\
\hline GN73-110 & 552 & $<100$ & $<100$ & 62,300 & $<100$ & 1,850 & 51,000 & 2,150 & 444 \\
\hline GN75-110 & 565 & $<100$ & $<100$ & 63,000 & $<100$ & 1,680 & 51,300 & 2,790 & 456 \\
\hline GN77-110 & 580 & $<100$ & $<100$ & 59,700 & $<100$ & 1,800 & 49,100 & 1,270 & 474 \\
\hline GN78-110 & 501 & $<100$ & $<100$ & 58,900 & $<100$ & 1,640 & 49,600 & 2,390 & 161 \\
\hline GN71-125 & 517 & $<100$ & $<100$ & 61,500 & $<100$ & 1,620 & 57,000 & 2,360 & 608 \\
\hline GN72-100 & 582 & $<100$ & $<100$ & 58,500 & $<100$ & 1,690 & 41,100 & 2,640 & 677 \\
\hline \multicolumn{10}{|c|}{ SRAT Product Supernate Anions, mg/L } \\
\hline GN70-100 & 699 & $<100$ & $<100$ & 67,800 & $<100$ & 2,370 & 66,600 & 569 & $<100$ \\
\hline GN76-100 & 827 & $<100$ & $<100$ & 70,900 & $<100$ & 2,320 & 65,500 & 456 & 889 \\
\hline GN74-100 & 727 & $<100$ & $<100$ & 74,500 & $<100$ & 2,260 & 54,100 & 491 & 266 \\
\hline GN79-100 & 647 & $<500$ & $<500$ & 67,700 & $<500$ & 2,220 & 60,500 & 652 & $<500$ \\
\hline GN73-110 & 779 & $<100$ & $<100$ & 84,800 & $<100$ & 2,230 & 55,300 & 1,660 & 243 \\
\hline GN75-110 & 718 & $<100$ & $<100$ & 84,800 & $<100$ & 1,930 & 53,800 & 1,360 & 131 \\
\hline GN77-110 & 756 & $<100$ & $<100$ & 82,700 & $<100$ & 2,320 & 58,600 & 1,270 & 240 \\
\hline GN78-110 & 869 & $<100$ & $<100$ & 80,900 & $<100$ & 2,500 & 70,100 & 1,540 & 105 \\
\hline GN71-125 & 645 & $<100$ & $<100$ & 79,400 & $<100$ & 2,590 & 68,500 & 3,510 & $<100$ \\
\hline GN72-100 & 843 & $<100$ & $<100$ & 76,400 & $<100$ & 2,340 & 52,700 & 450 & 379 \\
\hline \multicolumn{10}{|c|}{ SRAT Product Supernate Solubility, \% } \\
\hline GN70-100 & 97 & \multirow{10}{*}{ 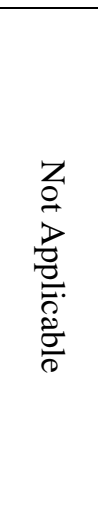 } & \multirow{10}{*}{ 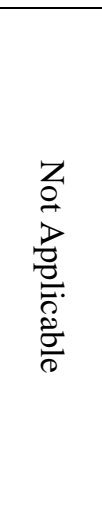 } & 104 & \multirow{10}{*}{ 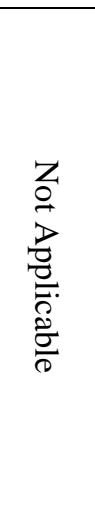 } & 103 & 101 & 13 & NA \\
\hline GN76-100 & 109 & & & 114 & & 107 & 103 & 9 & 67 \\
\hline GN74-100 & 93 & & & 104 & & 101 & 91 & 16 & 36 \\
\hline GN79-100 & 101 & & & 101 & & 93 & 98 & 15 & 125 \\
\hline GN73-110 & 111 & & & 108 & & 95 & 86 & 61 & 18 \\
\hline GN75-110 & 100 & & & 106 & & 90 & 82 & 38 & 23 \\
\hline GN77-110 & 101 & & & 107 & & 100 & 92 & 77 & 39 \\
\hline GN78-110 & 135 & & & 107 & & 119 & 110 & 50 & 51 \\
\hline GN71-125 & 100 & & & 103 & & 128 & 96 & 119 & NA \\
\hline GN72-100 & 113 & & & 101 & & 108 & 100 & 13 & 43 \\
\hline
\end{tabular}


Note that the expectation if all analyses were perfect is that the solubility of the anions would be $100 \%$ and the anion concentration for all duplicate experiments would be the same. In our experiments, there were differences from run to run. It should be noted that the anion data accuracy is $\pm 10 \%$. When comparing data between two runs, the data, generally analyzed on many different days, is expected to be within \pm $20 \%$. This was true in most cases, except where concentrations were less than $1,000 \mathrm{mg} / \mathrm{kg}$ or 1,000 mg/L.

Run GN75 is a duplicate of Run GN73, both at the 4-L scale. The nitrate concentration is very close for runs GN73 and 75 (differs by $650 \mathrm{mg} / \mathrm{kg}$, about 1\%) but the oxalate differs by $540 \mathrm{mg} / \mathrm{kg}$ (about 25\%). Looking at the four duplicate $110 \%$ runs at all three scales (Runs GN73, 75, 77 and 78); the nitrate concentration is higher for the higher acid stoichiometry runs (unless the product was over concentrated). But for the glycolate, the concentration is very similar for all runs. And for oxalate, the general trend is there is about $3,000 \mathrm{mg} / \mathrm{kg}$ in the SME product, more than is present in the incoming sludge so some oxalate and formate are produced during processing. It also is apparent that much of the oxalate is insoluble, especially at the lower acid stoichiometry. Chloride and sulfate are likely completely soluble so in runs where the solubility is different than $100 \%$ there is analytical uncertainty here that leads to a calculated bias. 
Table 3-11. SME Product Anions

\begin{tabular}{|c|c|c|c|c|c|c|c|c|c|}
\hline \multicolumn{10}{|c|}{ SME Product Slurry Anions, mg/kg } \\
\hline Run & $\mathrm{Cl}^{-}$ & $\mathrm{F}^{-}$ & $\mathrm{NO}_{2}^{-}$ & $\mathrm{NO}_{3}^{-}$ & $\mathrm{PO}_{4}^{3-}$ & $\mathrm{SO}_{4}{ }^{2-}$ & $\mathrm{C}_{2} \mathrm{H}_{3} \mathrm{O}_{3}^{-}$ & $\mathrm{C}_{2} \mathrm{O}_{4}{ }^{2-}$ & $\mathrm{CO}_{2} \mathrm{H}$ \\
\hline GN70-100 & 503 & $<100$ & $<100$ & 49,200 & $<100$ & 1,440 & 47,500 & 3,340 & 918 \\
\hline GN76-100 & 488 & $<100$ & $<100$ & 38,300 & $<100$ & 1,370 & 37,500 & 3,690 & 1,640 \\
\hline GN74-100 & 473 & $<100$ & $<100$ & 39,700 & $<100$ & 1,390 & 37,900 & 1,780 & 440 \\
\hline GN79-100 & 500 & NM & $<500$ & 41,800 & NM & 1,480 & 38,700 & 3,040 & 313 \\
\hline GN73-110 & 481 & $<100$ & $<100$ & 50,600 & $<100$ & 1,390 & 40,300 & 2,600 & 347 \\
\hline GN75-110 & 506 & $<100$ & $<100$ & 53,800 & $<100$ & 1,290 & 42,300 & 2,630 & 305 \\
\hline GN77-110 & 493 & $<100$ & $<100$ & 48,300 & $<100$ & 1,630 & 39,000 & 2,960 & 258 \\
\hline GN78-110 & 517 & NM & NM & 51,900 & NM & 1,660 & 43,300 & 2,830 & 108 \\
\hline GN71-125 & 463 & $<100$ & $<100$ & 58,100 & $<100$ & 1,400 & 52,500 & 2,620 & 501 \\
\hline GN72-100 & 513 & $<100$ & $<100$ & 50,700 & $<100$ & 1,410 & 39,500 & 3,660 & 1,090 \\
\hline \multicolumn{10}{|c|}{ SME Product Supernate Anions, mg/L } \\
\hline GN70-100 & 941 & $<100$ & $<100$ & 78,700 & $<100$ & 3,000 & 81,800 & 982 & $<100$ \\
\hline GN76-100 & 902 & $<100$ & $<100$ & 76,500 & $<100$ & 2,490 & 67,800 & 385 & 1,630 \\
\hline GN74-100 & 903 & $<100$ & $<100$ & 84,300 & $<100$ & 2,630 & 59,700 & 442 & 444 \\
\hline GN79-100 & 753 & NM & $<500$ & 70,700 & NM & 2,330 & 62,200 & 611 & $<500$ \\
\hline GN73-110 & 946 & $<100$ & $<100$ & 100,000 & $<100$ & 2,660 & 58,900 & 1,830 & 350 \\
\hline GN75-110 & 903 & $<100$ & $<100$ & 94,400 & $<100$ & 2,340 & 56,300 & 1,480 & 287 \\
\hline GN77-110 & 874 & $<100$ & $<100$ & 92,700 & $<100$ & 2,640 & 63,000 & 1,220 & 230 \\
\hline GN78-110 & 811 & $<100$ & $<100$ & 87,100 & $<100$ & 2,570 & 73,700 & 2,530 & 127 \\
\hline GN71-125 & 806 & $<100$ & $<100$ & 93,900 & $<100$ & 3,100 & 72,700 & 4,200 & $<100$ \\
\hline GN72-100 & 1,050 & $<100$ & $<100$ & 91,600 & $<100$ & 2,730 & 58,900 & 539 & 490 \\
\hline \multicolumn{10}{|c|}{ SME Product Supernate Solubility, \% } \\
\hline GN70-100 & 105 & \multirow{10}{*}{ 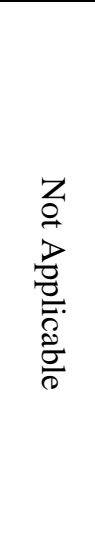 } & \multirow{10}{*}{ 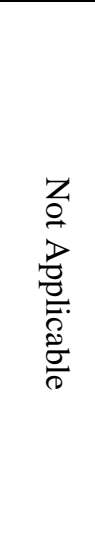 } & 89 & \multirow{10}{*}{ 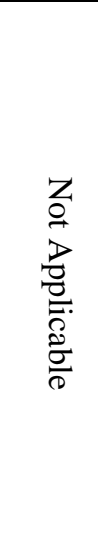 } & 116 & 96 & 16 & NA \\
\hline GN76-100 & 111 & & & 119 & & 109 & 108 & 6 & 59 \\
\hline GN74-100 & 111 & & & 124 & & 111 & 92 & 14 & 59 \\
\hline GN79-100 & 89 & & & 100 & & 93 & 95 & 12 & NA \\
\hline GN73-110 & 115 & & & 115 & & 112 & 101 & 84 & 111 \\
\hline GN75-110 & 106 & & & 104 & & 108 & 79 & 34 & 56 \\
\hline GN77-110 & 105 & & & 114 & & 96 & 96 & 25 & 5 \\
\hline GN78-110 & 86 & & & 92 & & 85 & 93 & 70 & 64 \\
\hline GN71-125 & 106 & & & 98 & & 134 & 84 & 97 & NA \\
\hline GN72-100 & 121 & & & 115 & & 115 & 101 & 80 & 99 \\
\hline
\end{tabular}

The waste loading in the SME products was calculated for each run and the results are summarized in Table 3-12. The planned waste loading for each of the runs was 36\%. For elements that are not added with the frit, the waste loading can be calculated by dividing the calcined solids in the SME product by the calcined solids in the SRAT product. For $\mathrm{Li}$, the SME Li concentration can be used to calculate waste 
loading (frit 418 is 8 wt \% $\mathrm{Li}_{2} \mathrm{O}$ or $3.72 \mathrm{wt} \% \mathrm{Li}$ ). Note that DWPF uses Fe (bolded in table) to calculate waste loading. The data varies considerably from run to run and element to element but averages about $36 \%$ for all the elements below.

Table 3-12. Calculated Waste Loading

\begin{tabular}{|l|c|l|l|l|l|l|l|l|l|}
\hline \multirow{2}{*}{ Run } & $\begin{array}{c}\text { GN70- } \\
\mathbf{1 0 0}\end{array}$ & $\begin{array}{c}\text { GN76- } \\
\mathbf{1 0 0}\end{array}$ & $\begin{array}{c}\text { GN74- } \\
\mathbf{1 0 0}\end{array}$ & $\begin{array}{c}\text { GN79- } \\
\mathbf{1 0 0}\end{array}$ & $\begin{array}{c}\text { GN73- } \\
\mathbf{1 1 0}\end{array}$ & $\begin{array}{c}\text { GN75- } \\
\mathbf{1 1 0}\end{array}$ & $\begin{array}{c}\text { GN77- } \\
\mathbf{1 1 0}\end{array}$ & $\begin{array}{c}\text { GN78- } \\
\mathbf{1 1 0}\end{array}$ & $\begin{array}{c}\text { GN71- } \\
\mathbf{1 2 5}\end{array}$ \\
\hline $\mathrm{Al}$ & $34.6 \%$ & $38.3 \%$ & $36.3 \%$ & $41.8 \%$ & $35.7 \%$ & $37.8 \%$ & $38.7 \%$ & $36.9 \%$ & $36.0 \%$ \\
\hline $\mathrm{Ca}$ & $25.9 \%$ & $32.1 \%$ & $35.1 \%$ & $26.0 \%$ & $29.4 \%$ & $37.4 \%$ & $31.3 \%$ & $28.0 \%$ & $30.4 \%$ \\
\hline $\mathrm{Cr}$ & $38.6 \%$ & $48.1 \%$ & $42.2 \%$ & $56.4 \%$ & $41.4 \%$ & $42.8 \%$ & $45.6 \%$ & $37.5 \%$ & $40.5 \%$ \\
\hline $\mathrm{Fe}$ & $\mathbf{3 0 . 2 \%}$ & $\mathbf{3 7 . 3 \%}$ & $\mathbf{3 5 . 1 \%}$ & $\mathbf{3 8 . 7 \%}$ & $\mathbf{3 9 . 4 \%}$ & $\mathbf{3 6 . 2 \%}$ & $\mathbf{3 5 . 6 \%}$ & $\mathbf{3 0 . 9 \%}$ & $\mathbf{3 3 . 0 \%}$ \\
\hline $\mathrm{Li}$ & $32.9 \%$ & $43.0 \%$ & $36.6 \%$ & $52.3 \%$ & $36.2 \%$ & $36.0 \%$ & $37.7 \%$ & $39.4 \%$ & $39.5 \%$ \\
\hline $\mathrm{Mg}$ & $31.4 \%$ & $38.9 \%$ & $34.6 \%$ & $44.6 \%$ & $34.4 \%$ & $35.6 \%$ & $38.0 \%$ & $36.1 \%$ & $35.5 \%$ \\
\hline $\mathrm{Mn}$ & $32.7 \%$ & $37.1 \%$ & $36.3 \%$ & $37.8 \%$ & $33.9 \%$ & $35.8 \%$ & $38.4 \%$ & $30.1 \%$ & $36.2 \%$ \\
\hline $\mathrm{Ni}$ & $24.4 \%$ & $33.4 \%$ & $29.5 \%$ & $33.8 \%$ & $28.5 \%$ & $29.9 \%$ & $36.2 \%$ & $28.2 \%$ & $28.6 \%$ \\
\hline $\mathrm{S}$ & $30.7 \%$ & $35.9 \%$ & $30.9 \%$ & $30.7 \%$ & $30.7 \%$ & $32.1 \%$ & $27.1 \%$ & $30.8 \%$ & $33.4 \%$ \\
\hline
\end{tabular}

An anion cation balance was completed using the SRAT and SME product filtrate sample results using all detectable anions and cations. The total anion charge equals to the cation charge in the samples. However, the analytical uncertainty leads to a calculated bias, the sum of charges does not always equal zero. The main contributors to the anion balance are glycolate and nitrate. The main contributor to the cation balance is sodium. Note that the carbonate concentration was not measured so is not included in the balance. The results are summarized in Table 3-13

Table 3-13. SRAT and SME Product Anion Cation Balance, $M$

\begin{tabular}{|l|c|c|c|c|c|c|c|c||}
\hline & \multicolumn{4}{|c|}{ SRAT Product } & \multicolumn{4}{c|}{ SME Product } \\
\hline Run & Anions & Cations & Sum & Delta & Anions & Cations & Sum & Delta \\
\hline GN70-100 & -2.07 & 1.72 & -0.34 & $-16.6 \%$ & -2.48 & 2.59 & 0.12 & $-4.8 \%$ \\
\hline GN76-100 & -2.12 & 1.74 & -0.38 & $-17.7 \%$ & -2.26 & 2.29 & 0.03 & $-1.4 \%$ \\
\hline GN74-100 & -2.01 & 1.96 & -0.04 & $-2.1 \%$ & -2.26 & 2.62 & 0.36 & $-15.9 \%$ \\
\hline GN79-100 & -1.99 & 1.90 & -0.09 & $-4.5 \%$ & -2.06 & 2.34 & 0.27 & $-13.2 \%$ \\
\hline GN73-110 & -2.21 & 1.77 & -0.44 & $-20.0 \%$ & -2.53 & 2.72 & 0.19 & $-7.3 \%$ \\
\hline GN75-110 & -2.18 & 1.85 & -0.33 & $-14.9 \%$ & -2.39 & 2.83 & 0.44 & $-18.3 \%$ \\
\hline GN77-110 & -2.22 & 1.73 & -0.49 & $-22.0 \%$ & -2.45 & 2.78 & 0.33 & $-13.6 \%$ \\
\hline GN78-110 & -2.35 & 1.97 & -0.39 & $-16.4 \%$ & -2.53 & 2.87 & 0.34 & $-13.5 \%$ \\
\hline
\end{tabular}

Note: Delta was calculated as the sum divided by the anion sum times 100

\subsubsection{Major Offgas Species}

The major offgas species $\left(\mathrm{CO}_{2}, \mathrm{O}_{2}, \mathrm{NO}, \mathrm{NO}_{2}\right.$, and $\left.\mathrm{N}_{2} \mathrm{O}\right)$ for the $100 \%$ and $110 \%$ acid stoichiometry runs are shown in Figure 3-1and Figure 3-2, respectively, for the early part of the SRAT cycle. The later portion of the SRAT cycle and SME cycle for all runs are similar with declining concentrations of $\mathrm{CO}_{2}$ and $\mathrm{NO}_{\mathrm{x}}$ species. An Elapsed Time of zero is the end of glycolic acid addition. The $\mathrm{N}_{2}$ concentrations are not shown. For both sets of runs, the $\mathrm{CO}_{2}$ and $\mathrm{O}_{2}$ profiles are very similar. Runs GN70, GN78 and GN79 had longer down times between the nitric and glycolic acid additions, so the $\mathrm{CO}_{2}$ peaks for these runs are at earlier relative times. Run GN73 had an intermediate length down time and so has its $\mathrm{CO}_{2}$ peak between GN78 and GN75/GN77. Accounting for the different down times, the $\mathrm{CO}_{2}$ graphs for each acid stoichiometry are almost identical. The end of nitric acid addition for all runs corresponded to being about half way down the 
first decline in the $\mathrm{CO}_{2}$ concentration. Carbonate was mostly decomposed by the end of nitric acid addition. The start of glycolic acid addition corresponds with the second rise in the $\mathrm{CO}_{2}$ concentration. 

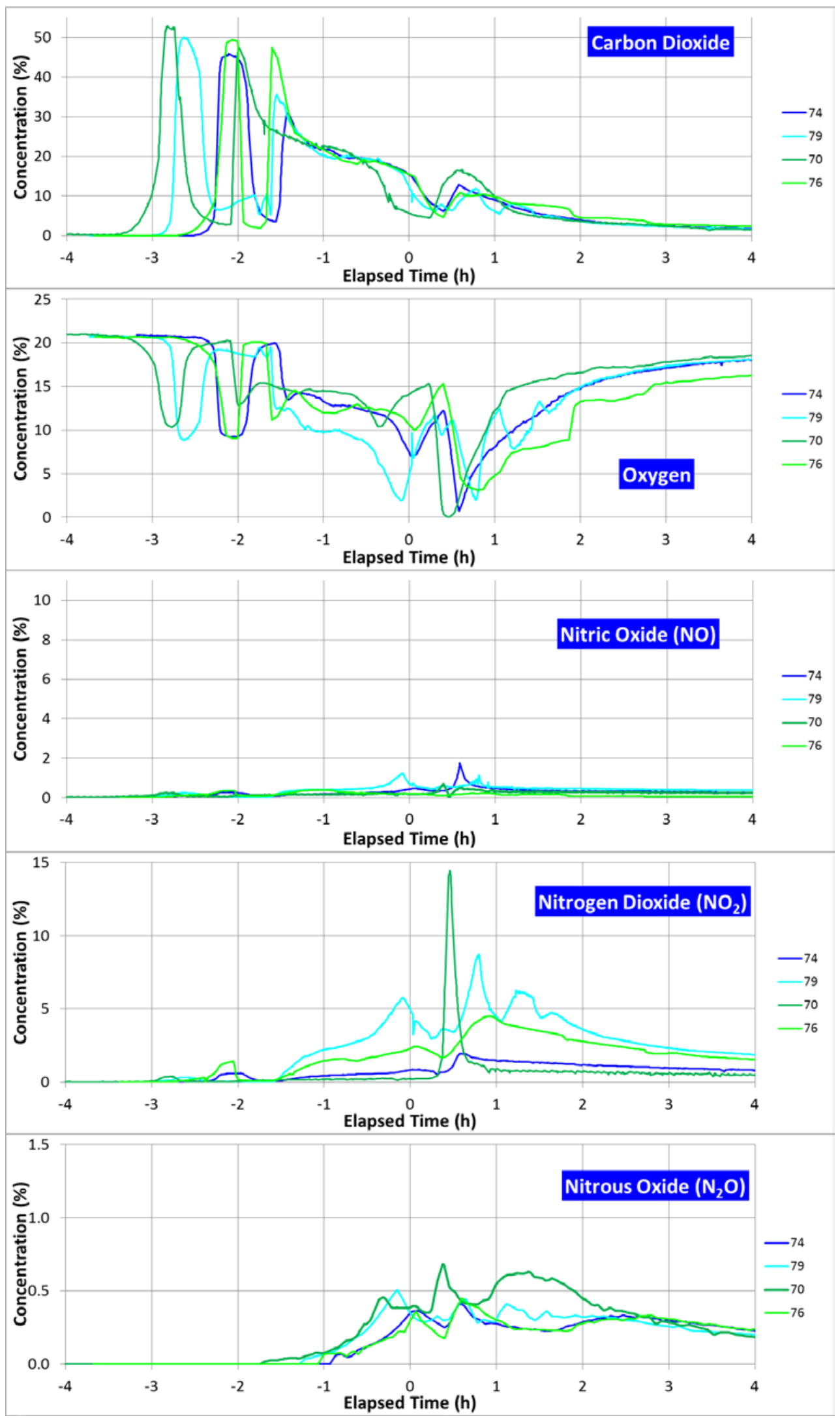

Figure 3-1. Offgas Concentrations from 100\% Stoichiometry Runs 


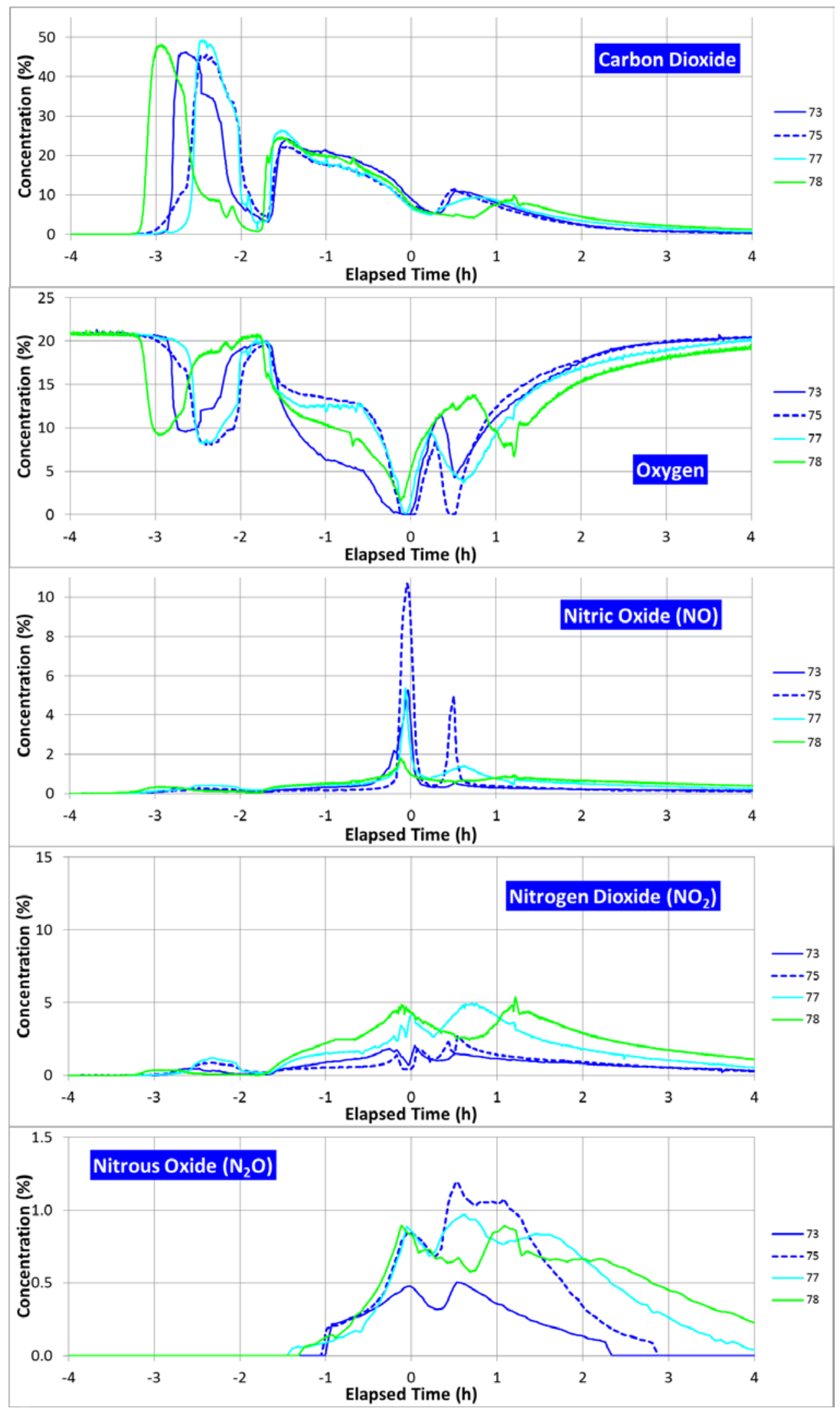

Figure 3-2. Offgas Concentrations from 110\% Stoichiometry Runs 
The $\mathrm{O}_{2}$ concentrations are also similar up to about -1 h. The drop in $\mathrm{O}_{2}$ concentration (along with nitrogen and helium) prior to $-1 \mathrm{~h}$ is totally due to dilution by the $\mathrm{CO}_{2}$. During the last hour of nitric acid addition, for the $110 \%$ runs, total oxygen depletion occurred at the end of glycolic acid addition, except for the 220-L run GN78 where the $\mathrm{O}_{2}$ concentration did not quite drop to zero. The oxygen depletion (nitrogen and helium are not depleted) during glycolic acid addition is mostly due to the reaction of NO emitted from the SRAT with $\mathrm{O}_{2}$ in the air purge to form $\mathrm{NO}_{2}$ :

$$
2 \mathrm{NO}+\mathrm{O}_{2} \rightarrow 2 \mathrm{NO}_{2}
$$

The drops in $\mathrm{O}_{2}$ concentration correspond with peaks in the $\mathrm{NO}_{\mathrm{x}}$ concentrations. Note that the $\mathrm{NO}_{\mathrm{x}}$ concentrations are not the total $\mathrm{NO}_{\mathrm{x}}$ emitted because a significant amount of $\mathrm{NO}_{\mathrm{x}}$ is scrubbed and removed in the ammonia scrubber or the SRAT condenser when in dewater mode. All of the $110 \%$ runs showed a second drop in $\mathrm{O}_{2}$ concentration at about the time the SRAT reached boiling after the end of glycolic acid addition. Runs GN73, GN75 and GN77 reached boiling at about 0.5 h, while GN79 boiled at about $1.2 \mathrm{~h}$. These drops also corresponded to $\mathrm{NO}_{\mathrm{x}}$ peaks.

For the $100 \%$ runs, the drop in the $\mathrm{O}_{2}$ concentration at the end of glycolic acid addition was much less for the 4-L and 22-L runs; the 220-L run GN79 had the largest drop, but it was still less than for the $110 \%$ runs. A second drop in $\mathrm{O}_{2}$ concentration occurred for all runs at about the time boiling was achieved ( 0.5-0.8 h). The drops in $\mathrm{O}_{2}$ concentration correspond with increases in the $\mathrm{NO}_{\mathrm{x}}$ concentrations; the $\mathrm{NO}_{\mathrm{x}}$ concentrations in the $110 \%$ runs were higher than the $100 \%$ runs and resulted in the lower $\mathrm{O}_{2}$ concentrations.

Large NO peaks were seen in the $110 \%$ 4-L and 22-L run. (For comparison, the $\mathrm{NO}$ and $\mathrm{NO}_{2}$ concentrations are plotted with the same y-axes for both the 100 and $110 \%$ runs.) The NO peaks were much smaller for the $110 \% 220-\mathrm{L}$ run and all of the $100 \%$ runs. Although several of the NO peaks were sharper than the $\mathrm{NO}_{2}$ peaks, the $\mathrm{NO}_{2}$ peaks were generally broader and the total $\mathrm{NO}_{2}$ predominated over $\mathrm{NO}$ in all of the runs. An exception was GN70, where the $\mathrm{NO}_{2}$ peak was much sharper than in any of the other runs. Note that there was significant air inleakage in the Nafion ${ }^{\circledR}$ dryer and at the inlet to the offgas pump to the MS and FTIR in run GN70 so the $\mathrm{NO}_{2}$ concentration was much higher than the other runs due to the reaction of $\mathrm{NO}$ and $\mathrm{O}_{2}$.

\subsubsection{Minor Offgas Species}

Figure 3-3 after $5 \mathrm{~h}$ elapsed time shows that the peaks in HMDSO concentration are actually very short sharp peaks followed by a more gradual rise and fall in concentration. The peaks in HMDSO concentration exactly correspond to antifoam additions. In some of the runs, there were also small peaks in HMDSO

during the SME cycle when the SME reached boiling after a canister decon or frit addition. Note that section 3.5.3 has a discussion of antifoam preparation and antifoam addition strategy. 
SRNL-STI-2014-00306

Revision 0

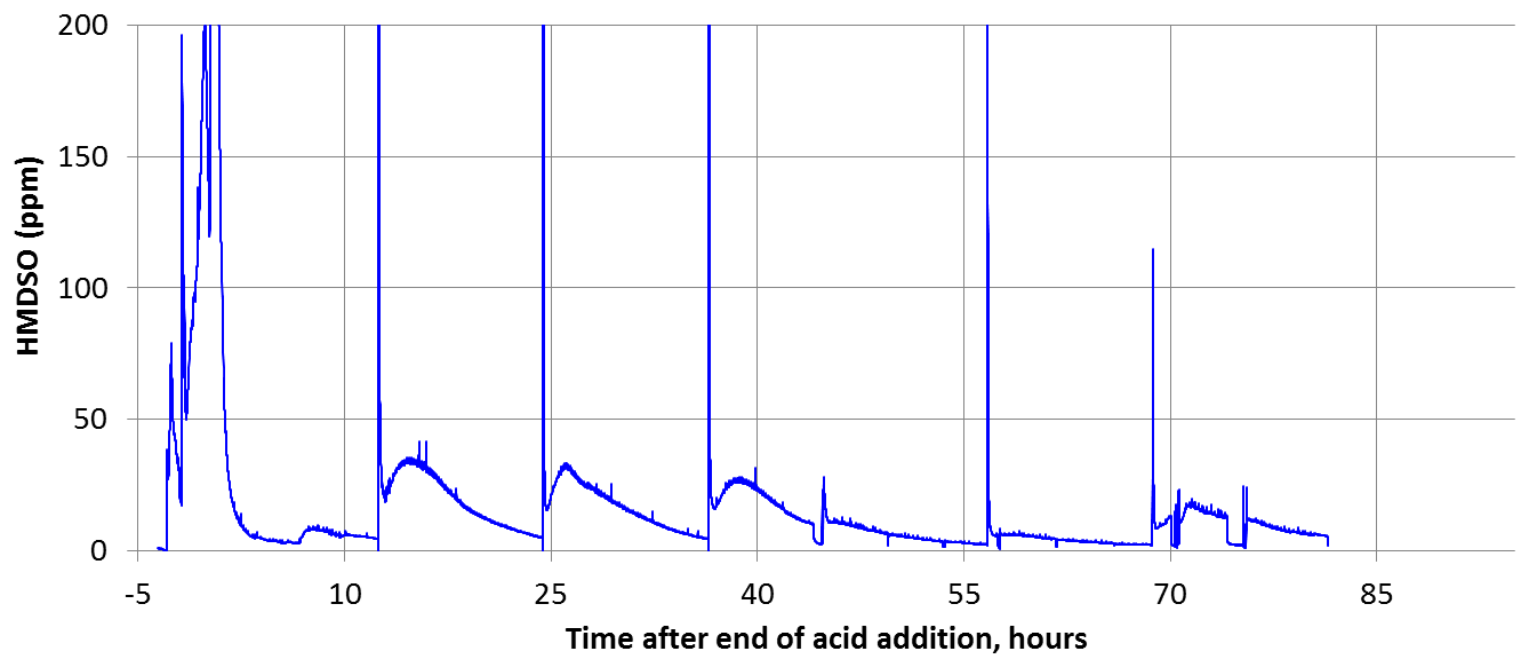

Figure 3-3. GN77 HMDSO Concentration

The molar ratio of the cumulative HMDSO evolved (times 2) to the antifoam added is plotted in Figure 3-4 for runs where antifoam was newly produced and HMDSO was measured by FTIR. Figure 3-4 shows the ratio of HMDSO observed in the offgas to the amount of antifoam added. Consistently, runs from all scales showed similar ratios of HMDSO to antifoam; in the range of 60 to $90 \%$. This further supports observations that indicated antifoam degrades significantly due to dilution with water before being added to the SRAT or SME vessels. The scale of the runs had no significant effect on antifoam degradation as the degradation was likely mainly a factor of the antifoam being diluted prior to addition to the vessels. 


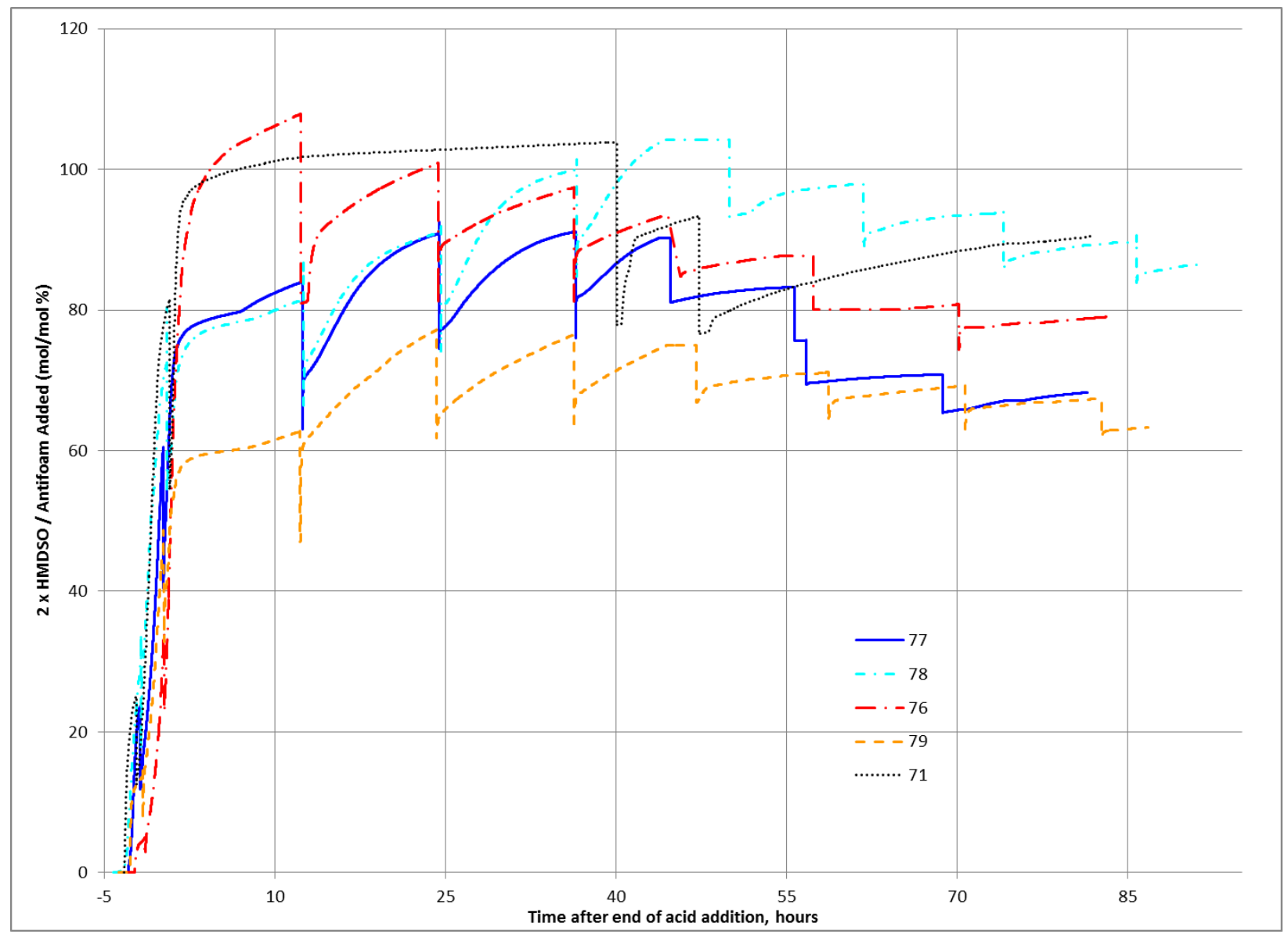

Figure 3-4. Ratio of Cumulative HMDSO Evolved in SRAT and SME Cycle to Antifoam Added

Two times the moles of HMDSO generated was used in the ratio because the proposed mechanism for antifoam degradation generates one HMDSO molecule per 2 antifoam molecules. This decomposition pathway is shown in Figure 3-5. ${ }^{14,21,22}$ These references propose that the acid or base hydrolysis of two antifoam molecules occurs with the formation of one HMDSO molecule and a polymeric siloxane ethoxylated derivative (PSED). This derivative can then decompose further to form more HMDSO and a polymer with three or more PE chains. These derivatives have been shown to have the property of causing foaming rather than inhibiting it. No evidence of further degradation of the PSEDs was evident from the offgas data, such as formation of methane $\mathrm{CH}_{4}$ from the $\mathrm{Si}-\mathrm{CH}_{3}$ portion of the molecules, was seen. Other decomposition products were observed when the offgas was sampled along the alternate path prior to the condensers and ammonia scrubber. These include trimethylsilanol ( TMS $\left.=\mathrm{Si}\left(\mathrm{CH}_{3}\right)_{3} \mathrm{OH}\right)$ and propanal ( $\mathrm{CH}_{3} \mathrm{CH}_{2} \mathrm{CHO}$ ) as reported elsewhere. ${ }^{23}$ Due to the water-soluble nature of these decomposition products, they were not initially observed in the offgas as they were being removed as the offgas was being processed through the traditional stream of condensers and the ammonia scrubber. TMS is produced when one fragment of the hydrolysis product of antifoam degradation becomes hydrogenated as opposed to combining with a second antifoam fragment. Propanal forms from the fragmentation of the PE tail between the carbonoxygen bond of the final ethylene oxide unit in the chain. No further significant degradation of the siloxane fragments or PSEDs was observed from the offgas analysis, such as the formation of methane $\left(\mathrm{CH}_{4}\right)$ from the methyl-silicon $\left(\mathrm{Si}-\mathrm{CH}_{3}\right)$ portions of the molecules. 


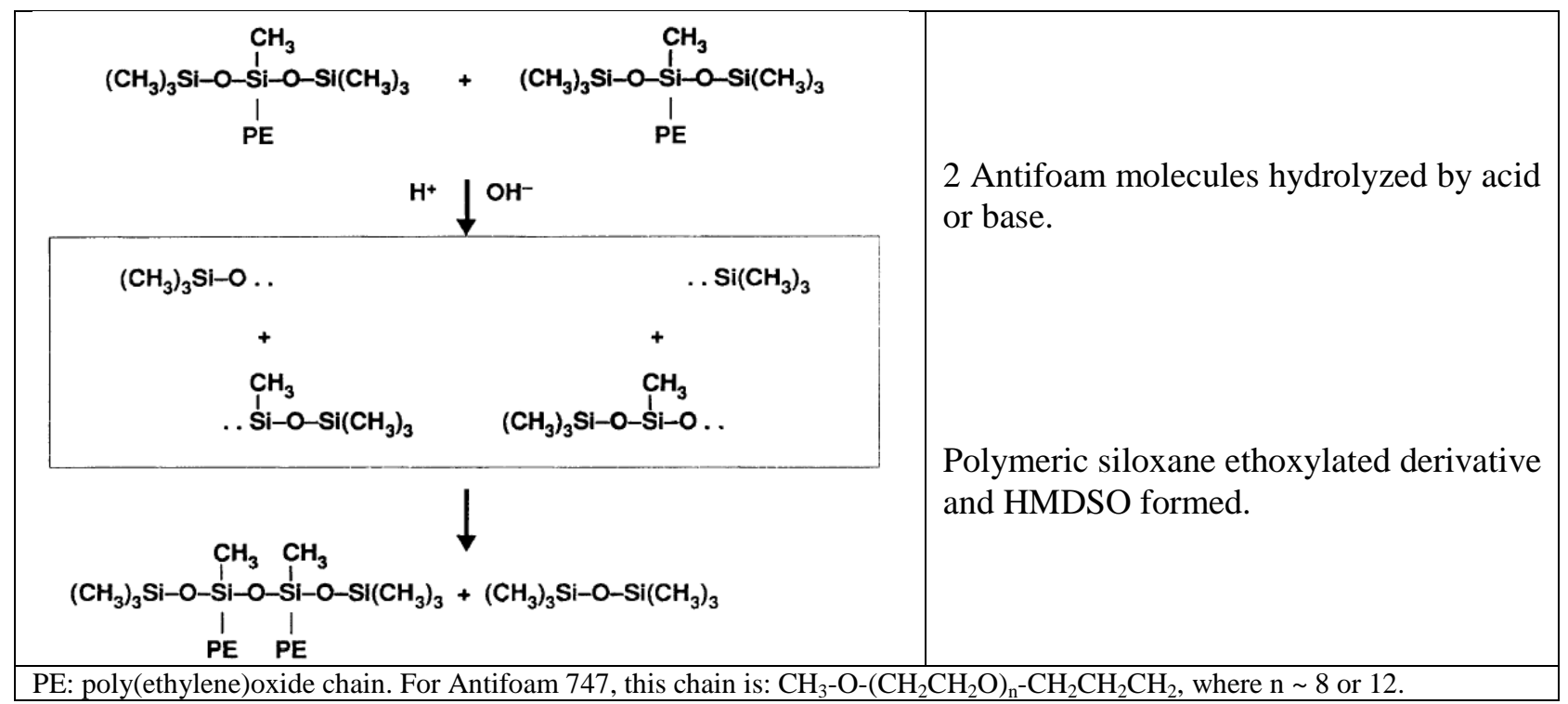

Figure 3-5. Decomposition Pathway for Antifoam

Figure 3-4 shows that for the 22-L and 220-L runs the amount of antifoam degraded, as indicated by the HMDSO evolved, was very consistent and in the range of 60 to $90 \%$ of the total antifoam. The two 4-L runs had much less degradation of about $40 \%$. There is no obvious reason why the degradation in the larger vessels would be twice that in the 4-L vessels.

\subsubsection{Nitrogen Chemistry Balance}

The starting sludge is high in nitrite and nitrate. More nitrates are added in the SRAT cycle as nitric acid. As the SRAT and SME cycles progress, the concentrations of nitrite and nitrate will change. To simplify the nitrogen balance, nitrogen gas will be ignored since in previous nitric-glycolic acid flowsheet testing there is no evidence nitrogen is being created. For example in Run GN75, a plot was made of the nitrogen to helium ratio. As can be seen in Figure 3-6, the ratio of nitrogen is virtually constant, suggesting that no nitrogen is produced in these reactions.

There are a series of oxidation states for nitrogen from $\mathrm{N}^{5+}$ in Nitrate $\left(\mathrm{NO}_{3}^{-}\right)$to $\mathrm{N}^{4+}$ in nitric oxide $\left(\mathrm{NO}_{2}\right)$ to $\mathrm{N}^{3+}$ in Nitrite $\left(\mathrm{NO}_{2}^{-}\right)$to $\mathrm{N}^{2+}$ in nitrogen oxide (NO) to $\mathrm{N}^{1+}$ in nitrous oxide $\left(\mathrm{N}_{2} \mathrm{O}\right)$ to $\mathrm{N}^{0}$ in nitrogen to $\mathrm{N}^{3-}$ in Ammonia $\left(\mathrm{NH}_{3}\right.$ or $\left.\mathrm{NH}_{4}{ }^{+}\right)$. These nitrogen species occur in both the liquid $\left(\mathrm{NO}_{3}{ }^{-}, \mathrm{NO}_{2}^{-}, \mathrm{NH}_{4}{ }^{+}\right)$and gas phase (NO, $\mathrm{NO}_{2}, \mathrm{~N}_{2} \mathrm{O}, \mathrm{N}_{2}, \mathrm{NH}_{3}$ ). As a result, the nitrogen balance needs to include the SRAT and SME products, offgas, dewater samples from condensers and FAVC, and ammonia scrubber samples. Therefore, each of these streams needs to be included in the balance although the bulk of the nitrogen species (excluding the nitrogen in the offgas) will be from the nitrate in the SRAT and SME products.

It should also be noted that the amount of nitrate in the SRAT and SME products depends on the extent of scrubbing of the nitrogen dioxide $\left(\mathrm{NO}_{2}\right)$ and the extent of oxidation of $\mathrm{NO}$ to $\mathrm{NO}_{2}$. In a less insulated rig, the vapor space in the SRAT would be colder so more nitrogen dioxide would be retained in the SRAT product as nitrate, whereas if the vapor space is better insulated, the $\mathrm{NO}_{2}$ in the offgas and the nitrate in the condensate would be higher. If the vapor space volume relative to the liquid volume is higher, there is more oxygen, so it is likely that more $\mathrm{NO}$ will be oxidized to $\mathrm{NO}_{2}$. So differences in the percent of nitrogen species in the balance are likely to be more affected by changes in geometry and insulation instead of a true difference due to scale. 


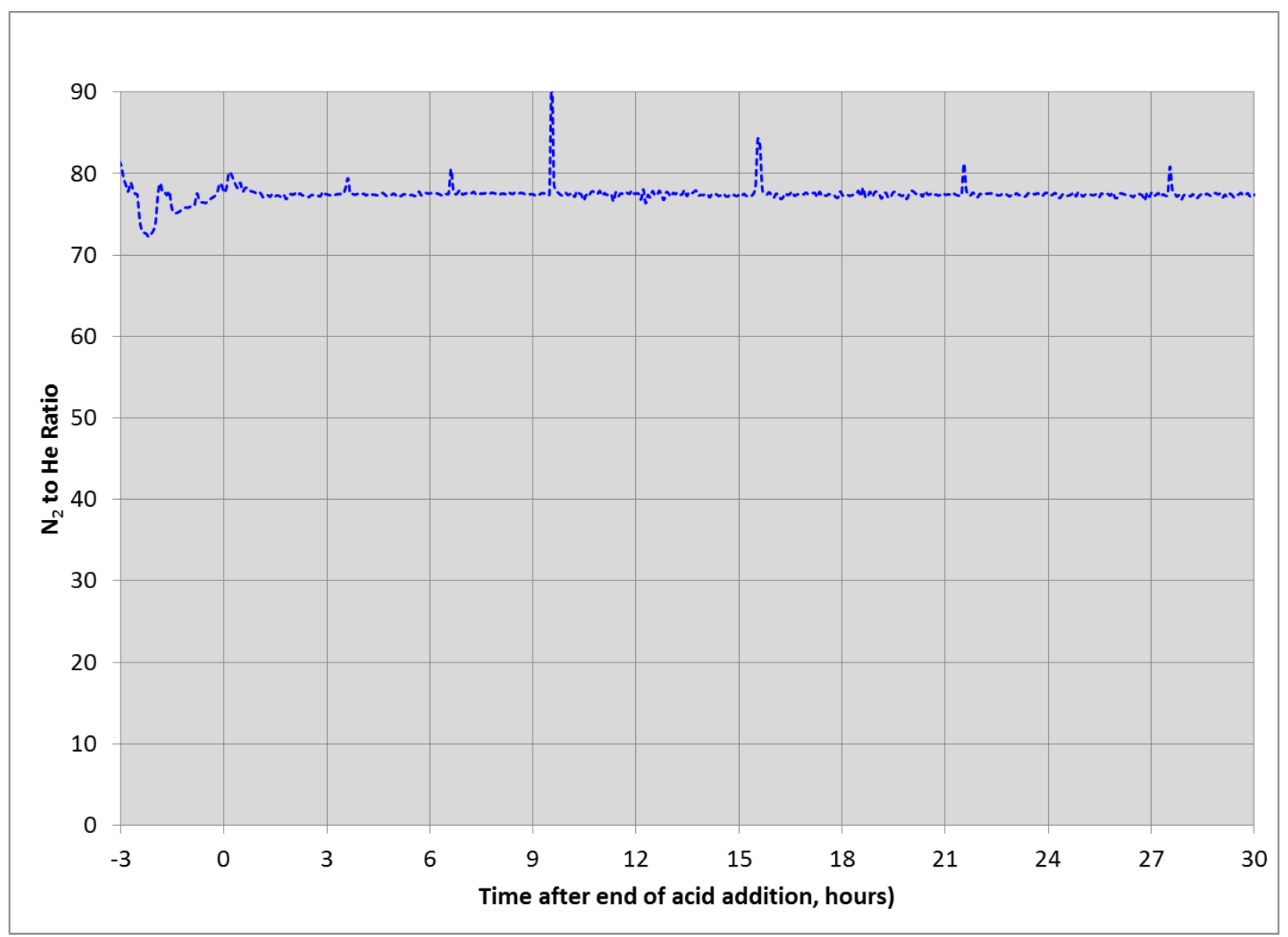

Figure 3-6. GN75 SRAT Cycle Nitrogen to Helium Ratio

In all runs, the nitrite was completely destroyed early in the SRAT cycle. Nitrite is destroyed through several competing reactions paths. A more complete discussion of the development of the GMA model can be found in the report on DWPF Nitric-Glycolic Flowsheet Chemical Process Cell Chemistry: Part $1 .^{11}$

A nitrogen mass balance was completed. The results from the mass balance are summarized in Table 3-14. An explanation of balance is summarized below:

- $\mathrm{NH}_{3}$ balance sums up the mols of $\mathrm{NH}_{4}{ }^{+}$in the scrub solution, condensate and SME product

- $\mathrm{N}_{2} \mathrm{O}$ balance sums up the mols of $\mathrm{N}$ from $\mathrm{N}_{2} \mathrm{O}$ in the offgas

- $\quad \mathrm{NO}$ balance sums up the mols of NO in the offgas

- $\quad \mathrm{NO}_{2}$ balance sums up the mols of $\mathrm{NO}_{2}$ in the offgas

- Nitrate balance sums up the mols of nitrate in the SME product, scrub solution and condensate

- The overall nitrogen balance compares the sum of the mols of nitrogen above to the mols of nitrogen from nitrite and nitrate in the sludge together with the moles of nitric acid added.

- In all runs, nitrite was completely destroyed in the SRAT

- SRAT nitrite to nitrate conversion is calculated as the mols of nitrate produced in the SRAT product divided by the mols of nitrite present in the sludge 
Table 3-14. Nitrogen Species Mass Balance Summary

\begin{tabular}{|c|c|c|c|c|c|c|c|c|}
\hline Acid Stoichiometry & \multicolumn{4}{|c|}{$100 \%$} & & \multicolumn{3}{|c|}{$110 \%$} \\
\hline Run & GN70 & GN76 & GN74 & GN79 & GN73 & GN75 & GN77 & GN78 \\
\hline Acid Ratio, Glycolic:Total & 0.5831 & 0.5831 & 0.5454 & 0.5454 & 0.5221 & 0.5221 & 0.5221 & 0.5221 \\
\hline Nitrogen overall balance & $95.3 \%$ & $95.6 \%$ & $97.4 \%$ & $93.2 \%$ & 93.9\% & $96.5 \%$ & $94.8 \%$ & $96.0 \%$ \\
\hline Nitrate balance & $95.1 \%$ & $89.4 \%$ & $95.0 \%$ & $88.9 \%$ & $96.9 \%$ & $96.3 \%$ & $93.8 \%$ & $93.0 \%$ \\
\hline NO balance & $2.1 \%$ & $0.7 \%$ & $1.3 \%$ & $2.0 \%$ & $0.9 \%$ & $1.2 \%$ & $1.3 \%$ & $1.4 \%$ \\
\hline $\mathrm{NO}_{2}$ balance & $3.9 \%$ & $9.0 \%$ & $3.0 \%$ & $8.2 \%$ & $1.8 \%$ & $1.9 \%$ & $4.2 \%$ & $4.8 \%$ \\
\hline $\mathrm{N}_{2} \mathrm{O}$ balance & $0.9 \%$ & $0.9 \%$ & $0.7 \%$ & $0.9 \%$ & $0.3 \%$ & $0.6 \%$ & $0.8 \%$ & $0.9 \%$ \\
\hline $\mathrm{NH}_{3}$ balance & $0.0 \%$ & $0.0 \%$ & $0.0 \%$ & $0.0 \%$ & $0.0 \%$ & $0.0 \%$ & $0.0 \%$ & $0.0 \%$ \\
\hline SRAT Nitrite Destruction & $100 \%$ & $100 \%$ & $100 \%$ & $100 \%$ & $100 \%$ & $100 \%$ & $100 \%$ & $100 \%$ \\
\hline $\begin{array}{l}\text { SRAT Nitrite to Nitrate } \\
\text { Conversion }\end{array}$ & $37.6 \%$ & $28.5 \%$ & $38.9 \%$ & $35.1 \%$ & $57.2 \%$ & $56.6 \%$ & $45.5 \%$ & $42.0 \%$ \\
\hline SME Nitrate Destruction & $19.3 \%$ & $23.3 \%$ & $20.3 \%$ & $-2.5 \%$ & $15.8 \%$ & $17.4 \%$ & $21.6 \%$ & $17.3 \%$ \\
\hline
\end{tabular}

Note: The color shading used in the above table is shown below (green is excellent, yellow is good, red is unacceptable)

\begin{tabular}{|l|l|}
\hline & $+/-10 \%$ \\
\hline & $+/-20 \%$ \\
\hline & $+/-50 \%$ \\
\hline
\end{tabular}

The nitrogen mass balance closure was greater than $90 \%$ for all runs. The bulk of the nitrogen is present as nitrate. About $90 \%$ of the nitrate is in the SRAT and SME slurry and the rest is in the condensate, primarily from the SRAT dewater and ammonia scrubber scrub solution. The remainder of the nitrogen compounds are a combination of $\mathrm{NO}_{2}, \mathrm{NO}$, and $\mathrm{N}_{2} \mathrm{O}$. Nitrite is completely destroyed during processing, with the bulk going to increasing SRAT nitrate, some increasing the condensate nitrate and the rest exiting in the offgas.

Table 3-15 shows that about $20 \%$ of the $\mathrm{NO}_{\mathrm{x}}$ in the $22-\mathrm{L}$ and $220-\mathrm{L}$ runs was $\mathrm{NO}$, and that about $37 \%$ was NO in the 4-L 100 and $110 \%$ runs. There may also be a secondary effect of acid stoichiometry on the NO to $\mathrm{NO}_{\mathrm{x}}$ ratio, with higher acid stoichiometry favoring more $\mathrm{NO}$ as shown in the table. The $100 \%$ runs had higher $\mathrm{NO}_{2}$ than the $110 \%$ runs at the same scale, and the $125 \%$ acid GN71 run had the highest $\mathrm{NO} / \mathrm{NO}_{\mathrm{x}}$ ratio. 
Table 3-15. Percentage of $\mathrm{NO}_{\mathrm{x}}$ Found in Condensates and NO/NO${ }_{\mathrm{x}}$ Ratio - A Function of Scale

\begin{tabular}{|c|c|c|c|c|c|c|}
\hline Run & $\begin{array}{c}\text { Acid \% } \\
\text { Stoichiometry }\end{array}$ & $\begin{array}{l}\text { Nitri } \\
\text { Syste } \\
\text { Con }\end{array}$ & $\begin{array}{l}\text { Offgas } \\
\text { und in } \\
\text { tes \% }\end{array}$ & & $\mathrm{NO}_{\mathrm{x}} \mathrm{R}$ & \\
\hline & & & Mean & & Mean & Mean \\
\hline GN73 & 110 & 68 & \multirow{4}{*}{66} & 40 & \multirow{2}{*}{42} & \multirow{4}{*}{37} \\
\hline GN75 & 110 & 62 & & 44 & & \\
\hline GN74 & 100 & 69 & & 31 & \multirow{2}{*}{33} & \\
\hline GN70 & 100 & 63 & & 35 & & \\
\hline GN77 & 110 & 38 & \multirow{4}{*}{41} & 28 & \multirow{2}{*}{27} & \multirow{4}{*}{20} \\
\hline GN78 & 110 & 44 & & 26 & & \\
\hline GN76 & 100 & 45 & & 8 & \multirow{2}{*}{14} & \\
\hline GN79 & 100 & 38 & & 20 & & \\
\hline GN71 & 125 & 63 & 63 & 51 & & 51 \\
\hline
\end{tabular}

Blue: 4-L runs

Italics: not a scaled run

The peak in total $\mathrm{NO}_{\mathrm{x}}$ emission for all runs occurred near the end or after the glycolic acid addition, as shown in Figure 3-7. The 110\% acid stoichiometry runs tended to have larger peaks at the end of glycolic acid addition, whereas for the $100 \%$ acid runs, the peaks occurred when the SRAT reached boiling. A second peak in $\mathrm{NO}_{\mathrm{x}}$ then occurred when boiling for dewater was achieved. 

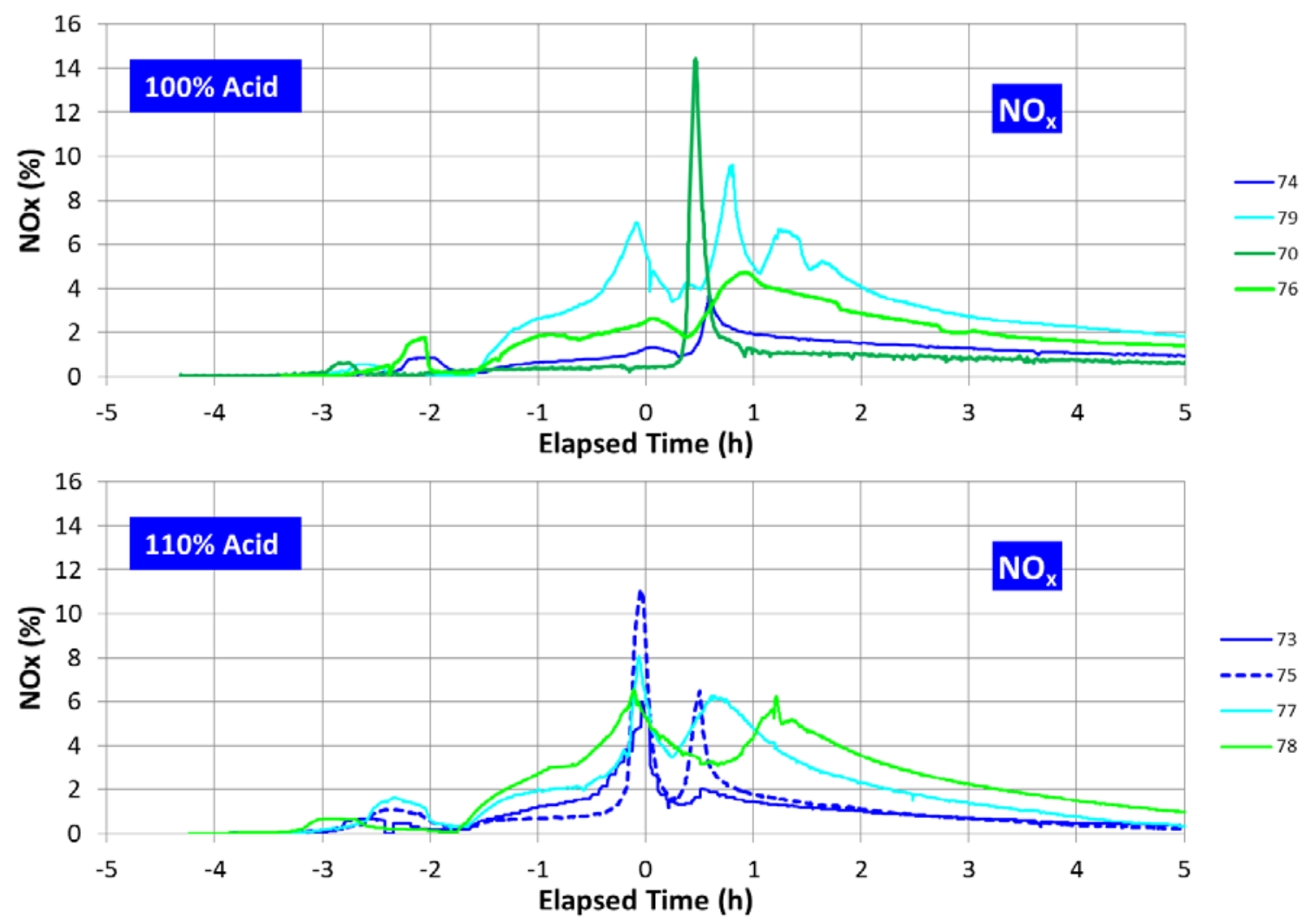

Figure 3-7. Early SRAT Cycle $\mathrm{NO}_{\mathrm{x}}$ Concentrations

It has been generally assumed that most, if not all, of the $\mathrm{NO}_{\mathrm{x}}$ that exits the SRAT liquid is almost completely $\mathrm{NO}$. $\mathrm{NO}_{2}$ is then formed by reaction with $\mathrm{O}_{2}$ in the vapor space and offgas lines.

It is important to note that a significant amount of the $\mathrm{NO}_{2}$ exiting the SRAT vessel is scrubbed in the SRAT condenser and the ammonia scrubber. Nitrogen dioxide $\mathrm{NO}_{2}$ is scrubbed to form $\mathrm{HNO}_{3}$ and $\mathrm{NO}$ :

$$
3 \mathrm{NO}_{2}+\mathrm{H}_{2} \mathrm{O} \rightarrow 2 \mathrm{HNO}_{3}+\mathrm{NO}
$$

Accounting for this reaction shows that the NO detected at the analyzers is the sum of NO from the SRAT that has not reacted with $\mathrm{O}_{2}$ and $\mathrm{NO}$ formed during the scrubbing of $\mathrm{NO}_{2}$. It is difficult if not impossible to back calculate from the measured offgas compositions what the SRAT offgas must have been.

The nitrate concentration in the dewater and ammonia scrub solution were measured, and the amounts of nitrite plus nitrate removed from the SRAT in samples during the run were estimated to give the amount of nitrogen species not accounted for in the offgas and the SRAT product. An overall material balance on nitrogen was then performed for each run. The nitrite to nitrate (in SRAT product) conversion is shown in Table 3-16 and Figure 3-8. The nitrite to nitrate conversion was calculated two ways. One way used the increase in nitrate concentration in the SRAT liquid not due to the $\mathrm{HNO}_{3}$ addition, and the second way used the total $\mathrm{N}_{\mathrm{y}} \mathrm{O}_{\mathrm{x}}$ in the offgas system (nitrite that didn't form nitrate) to calculate the nitrate concentration increase. The results from these two calculation methods gave results that trended similarly. The mean values of these two methods are shown in Table 3-16. 
Table 3-16. Nitrite Conversion to Nitrate - A Function of Acid Stoichiometry

\begin{tabular}{|c|c|c|c|c|c|c|}
\hline \multirow[b]{2}{*}{ Run } & \multirow[b]{2}{*}{$\begin{array}{c}\text { Acid \% } \\
\text { Stoichiometry \& } \\
\text { Glycolic Acid \% }\end{array}$} & \multicolumn{4}{|c|}{ Nitrite to Nitrate Conversion (\%) } & \multirow{2}{*}{$\begin{array}{c}\begin{array}{c}\text { Nitrogen } \\
\text { Balance } \\
\text { Closure (\%) } \\
\end{array} \text { Mean: } 104.2 \\
\end{array}$} \\
\hline & & $\begin{array}{c}\text { From } \\
\text { SRAT } \\
\text { Analyses }\end{array}$ & $\begin{array}{c}\text { From } \\
\text { Offgas } \\
\mathrm{N}_{\mathrm{y}} \mathrm{O}_{\mathrm{x}}\end{array}$ & $\begin{array}{c}\text { Mean for } \\
\text { Run }\end{array}$ & $\begin{array}{l}\text { Mean for } \\
\text { Stoich. }\end{array}$ & \\
\hline GN74 & $100 \quad 54.5 *$ & 45 & 34 & 40 & \multirow{4}{*}{35} & 107 \\
\hline GN79 & $100 \quad 54.5 *$ & 33 & 35 & 34 & & 103 \\
\hline GN70 & $100 \quad 58.3 *$ & 37 & 29 & 33 & & 107 \\
\hline GN76 & $100 \quad 58.3^{*}$ & 26 & 39 & 32 & & 100 \\
\hline GN73 & $110 \quad 52.2$ & 57 & 58 & 57 & \multirow{4}{*}{52} & 104 \\
\hline GN75 & $110 \quad 52.2$ & 61 & 54 & 58 & & 106 \\
\hline GN77 & 52.2 & 46 & 56 & 51 & & 102 \\
\hline GN78 & $110 \quad 52.2$ & 39 & 47 & 43 & & 102 \\
\hline GN71 & $125 \quad 55.0$ & 53 & 69 & 61 & 61 & 100 \\
\hline
\end{tabular}

Blue lettering indicates 4-L CPC tests Italics: not a scaled run

* Explanation for differences in runs explained in REDOX Section

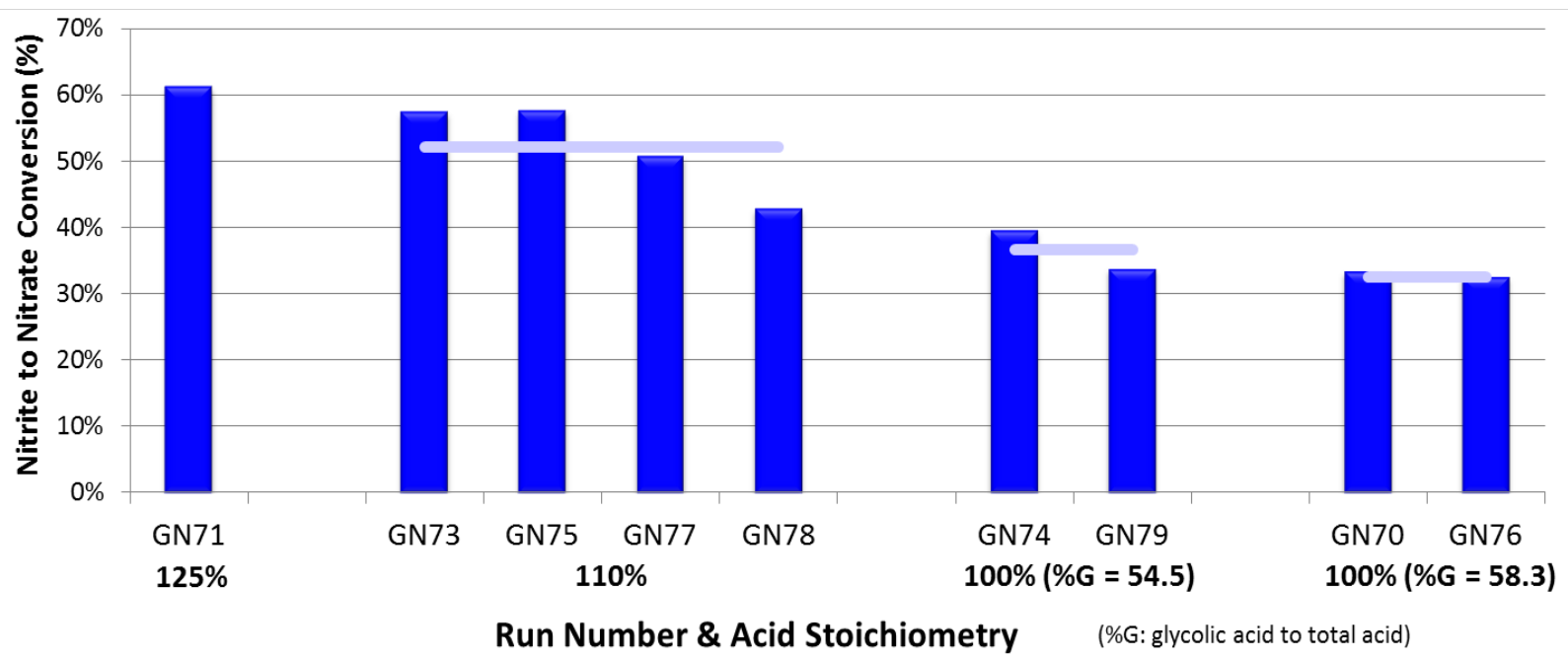

Figure 3-8. Nitrite to Nitrate Conversion 


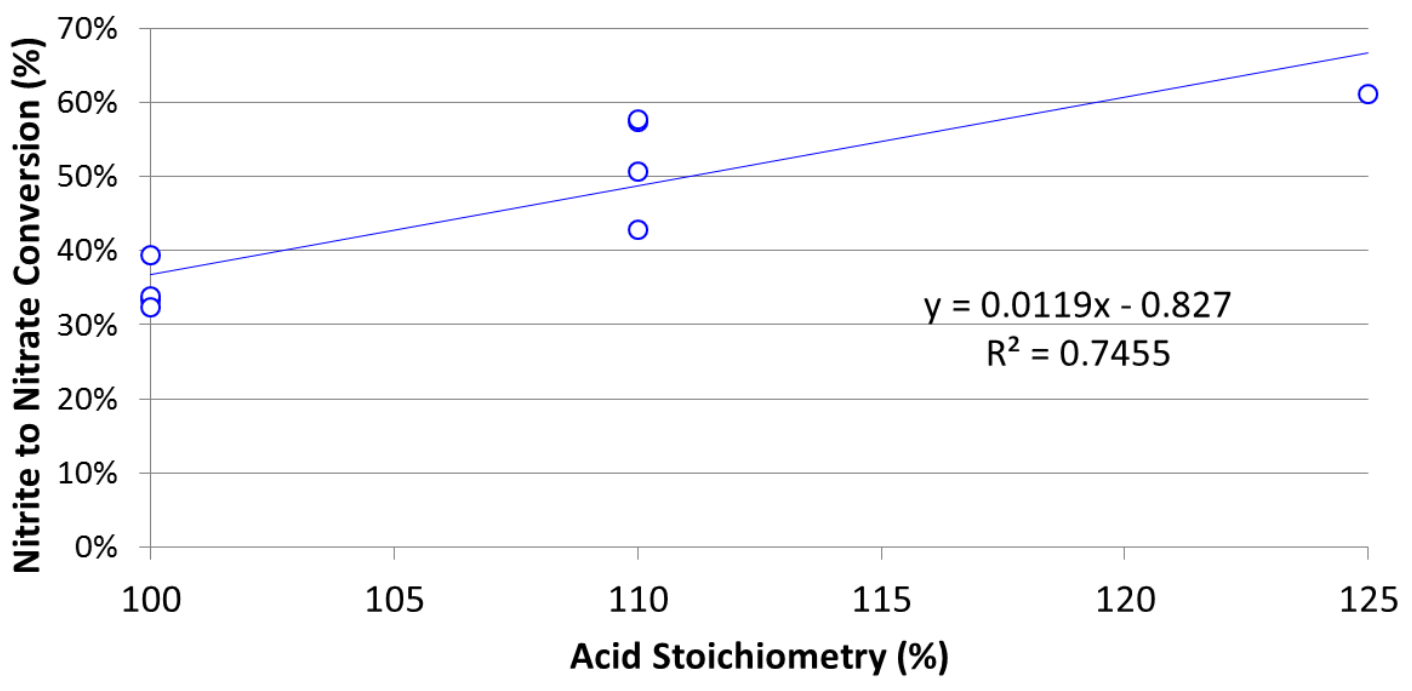

Figure 3-9. $\quad$ Nitrate to Nitrate Conversion Linear Fit to Acid Stoichiometry

The nitrite to nitrate conversion is approximately a linear function of acid stoichiometry for this particular sludge composition, as shown in Figure 3-9. There does appear to be a minor effect of scale on this conversion for a given stoichiometry. Note this specific linear relationship may not necessarily apply to different sludges. Predictive knowledge of this conversion is required to be able to predict glass REDOX from a given feed composition and acid stoichiometry. Further examination of historic nitric-glycolic acid flowsheet data is planned to examine this relationship for additional sludges.

The distribution of nitrogen species in the offgas system is given in Table 3-17. The distribution of the $\mathrm{NO}_{\mathrm{x}}$ species between the offgas exiting the ammonia scrubber and that absorbed in the scrubber as nitrate plus in the dewater condensate is a function of the equipment scale. The 4-L runs had about $66 \%$ of the nitrogen species found in the condensates, whereas the 22- $\mathrm{L}$ and 220 - $\mathrm{L}$ runs had about $41 \%$ in the condensates. There was no apparent difference in the nitrogen distribution between the 22- $\mathrm{L}$ and 220-L tests. It is known that the ammonia scrubber in the 4- $\mathrm{L}$ equipment is relatively oversized compared to the 22- $\mathrm{L}$ and $220-\mathrm{L}$ tests, so it would be expected to scrub more $\mathrm{NO}_{2}$; this is exactly what was seen in these runs. There also was no apparent correlation with acid stoichiometry. The distribution of nitrogen species in the offgas system is a function of the experiment scale and not the SRAT chemistry, so these conclusions do not directly apply to DWPF operation.

For both the 100 and $110 \%$ acid runs, $\mathrm{N}_{2} \mathrm{O}$ comprised about $9-10 \%$ of the total nitrogen emissions, as shown in Table 3-17. For the $125 \%$ acid run GN71, the relative amount of $\mathrm{N}_{2} \mathrm{O}$ produced was larger, which would be expected because more glycolic acid was added. However, more than one data point is needed to draw any definitive conclusions. 
Table 3-17. Percentage of Nitrogen to Offgas System as $\mathrm{N}_{2} \mathrm{O}$

\begin{tabular}{|c|c|c|c|}
\hline \multirow[t]{2}{*}{ Run } & \multirow[t]{2}{*}{$\begin{array}{c}\text { Acid \% } \\
\text { Stoichiometry } \\
\end{array}$} & \multicolumn{2}{|c|}{$\begin{array}{l}\text { Nitrogen } \% \text { in } \\
\text { Offgas* as } \mathrm{N}_{2} \mathrm{O}\end{array}$} \\
\hline & & & Mean \\
\hline GN74 & 100 & 14 & \multirow{4}{*}{10} \\
\hline GN79 & 100 & 8 & \\
\hline GN70 & 100 & 12 & \\
\hline GN76 & 100 & 8 & \\
\hline GN73 & 110 & 8 & \multirow{4}{*}{10} \\
\hline GN75 & 110 & 13 & \\
\hline GN77 & 110 & 11 & \\
\hline GN78 & 110 & 9 & \\
\hline GN71 & 125 & 16 & 16 \\
\hline
\end{tabular}

$*$ offgas $=\mathrm{NO}+\mathrm{NO}_{2}+\mathrm{N}_{2} \mathrm{O}+$ condensate nitrate

Blue: 4-L runs Italics: not a scaled run

Nitrite is one of the most reactive species in SRAT chemistry. Each sample that is reported below was quenched with sodium hydroxide to prevent the continuing nitrite destruction after sampling. The caustic quenched sample was analyzed by ion chromatography.

In the nitric-formic acid flowsheet, the noble metal catalyzed hydrogen generation does not begin until nitrite is destroyed. The destruction of nitrite is important as the bulk of the hydrogen generation is produced in the SRAT where the air purge is much larger than in the SME.

In the nitric-glycolic acid flowsheet, the nitrite is quickly destroyed early in SRAT boiling. And since little hydrogen is generated, the destruction of nitrite has no impact on SRAT or SME processing. The nitrite was destroyed fastest in the highest acid stoichiometry run. The nitrite was destroyed within three hours in the $110 \%$ acid stoichiometry runs and within eight hours in the $100 \%$ acid stoichiometry runs. The nitrite is below the DWPF analytical detection limit of $1,000 \mathrm{mg} / \mathrm{L}$. The nitrite concentration profile for each of the runs is summarized in Figure 3-10.

Approximately $40 \%$ of the nitrite is converted to nitrate in the sludge. As a result, the SRAT nitrate concentration increases at the same time the nitrite concentration is decreasing. The nitrate concentration profile for each of the runs is summarized in Figure 3-11. 

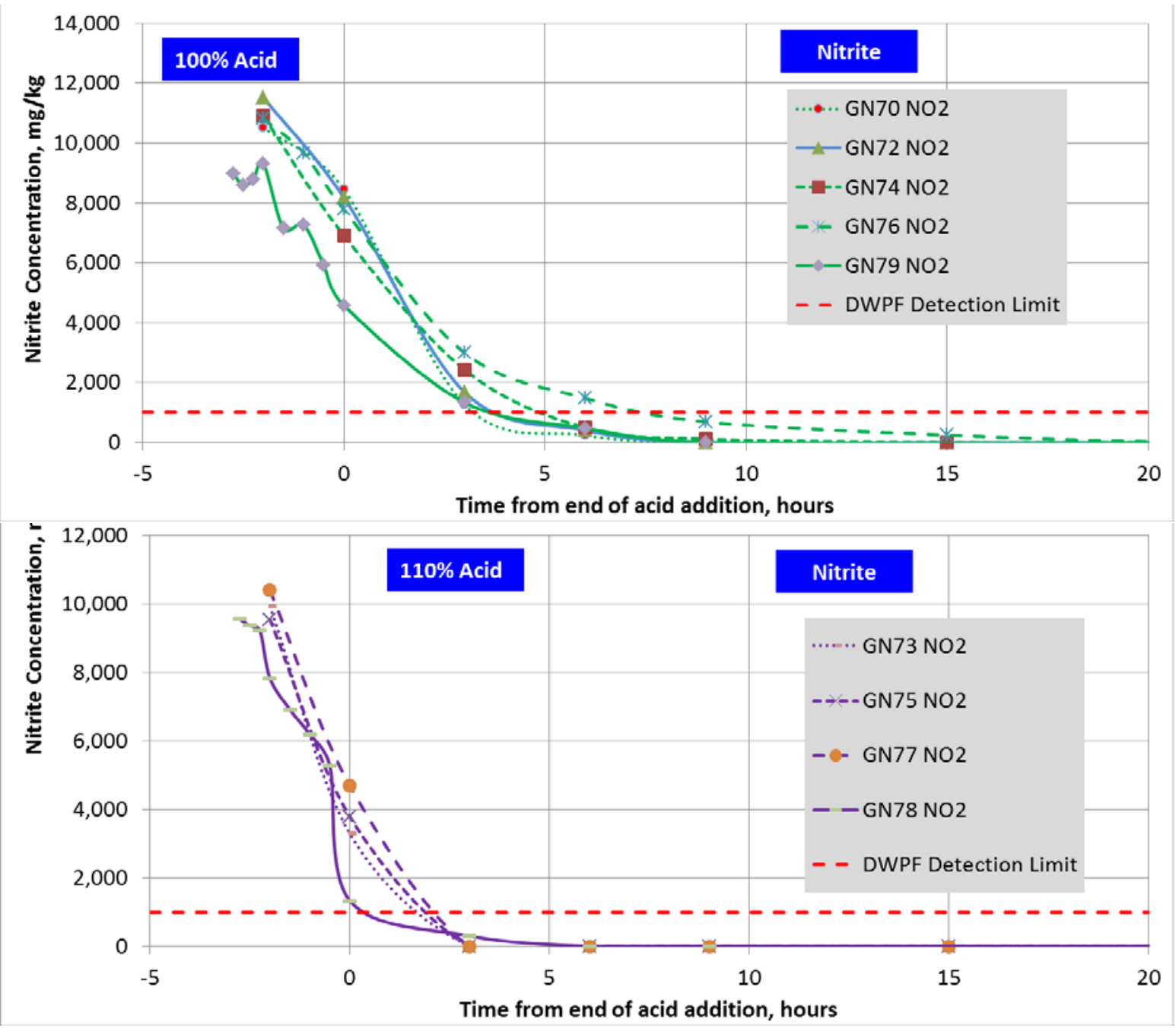

Figure 3-10. Nitrite Destruction during SRAT Cycle 

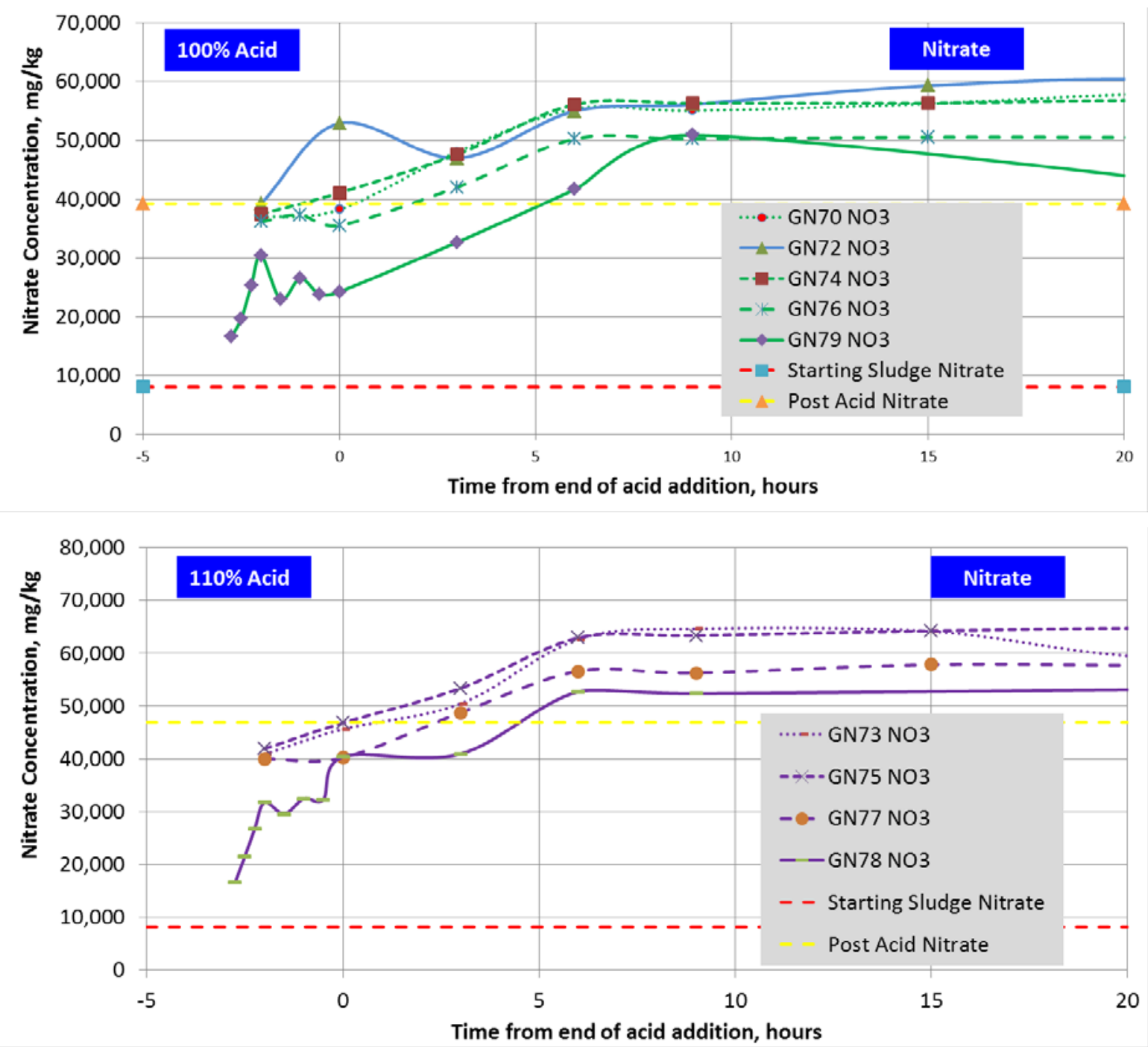

Figure 3-11. Nitrate Generation during SRAT Cycle

\subsubsection{Carbon Chemistry Balance}

The starting sludge is high in carbonate and contains some oxalate. In addition, glycolate is added as glycolic acid during acid addition in the SRAT. In addition, Antifoam 747 (containing carbon, silicon, oxygen and hydrogen) also adds additional carbon. In all the runs, the carbonate was completely destroyed:

$$
\mathrm{Na}_{2} \mathrm{CO}_{3}+2 \mathrm{HA} \rightarrow \mathrm{CO}_{2}+2 \mathrm{NaA}+\mathrm{H}_{2} \mathrm{O}
$$

(A is nitrate or glycolate ion, HA is nitric or glycolic acid)

Below is a summary of data from the carbon balance (Table 3-18). The carbon mass balance was greater than $90 \%$ for all runs. About $75 \%$ of the carbon is present as glycolate. About $20 \%$ of the carbon is $\mathrm{CO}_{2}$, from carbonate destruction and reduction reactions. Very little $(<<0.01 \%)$ of the carbon is present in the condensate. The remainder of the carbon is present as oxalate and formate in the SRAT and SME products. 
Table 3-18. Carbon Species Mass Balance Summary

\begin{tabular}{|c|c|c|c|c|c|c|c|c|}
\hline \multirow{2}{*}{$\begin{array}{l}\text { Acid Stoichiometry } \\
\text { Run }\end{array}$} & \multicolumn{4}{|c|}{$100 \%$} & \multicolumn{4}{|c|}{$110 \%$} \\
\hline & GN70 & GN76 & GN74 & GN79 & GN73 & GN75 & GN77 & GN78 \\
\hline Acid Ratio, Glycolic:Total & 0.5831 & 0.5831 & 0.5454 & 0.5454 & 0.5221 & 0.5221 & 0.5221 & 0.5221 \\
\hline Carbon overall balance & $99.7 \%$ & $102 \%$ & $94.4 \%$ & $100 \%$ & $98.5 \%$ & $102 \%$ & $97.9 \%$ & $99.6 \%$ \\
\hline Glycolate C balance & $74.9 \%$ & $71.9 \%$ & $75.5 \%$ & $73.0 \%$ & $77.4 \%$ & $76.4 \%$ & $76.0 \%$ & $75.5 \%$ \\
\hline Oxalate C balance & $4.3 \%$ & $4.7 \%$ & $3.3 \%$ & $4.5 \%$ & $2.8 \%$ & $3.5 \%$ & $1.7 \%$ & $3.1 \%$ \\
\hline Formate C balance & $1.0 \%$ & $1.2 \%$ & $0.8 \%$ & $0.4 \%$ & $0.6 \%$ & $0.6 \%$ & $0.6 \%$ & $0.2 \%$ \\
\hline $\mathrm{CO}_{2} \mathrm{C}$ balance & $19.7 \%$ & $22.1 \%$ & $20.4 \%$ & $22.0 \%$ & $19.2 \%$ & $19.4 \%$ & $21.7 \%$ & $21.0 \%$ \\
\hline CO C balance & $0.0 \%$ & $0.0 \%$ & $0.0 \%$ & $0.0 \%$ & $0.0 \%$ & $0.0 \%$ & $0.0 \%$ & $0.0 \%$ \\
\hline Antifoam C balance & $0.0 \%$ & $0.0 \%$ & $0.0 \%$ & $0.0 \%$ & $0.0 \%$ & $0.0 \%$ & $0.0 \%$ & $0.0 \%$ \\
\hline SRAT glycolate Destruction & $16.6 \%$ & $18.1 \%$ & $19.8 \%$ & $17.5 \%$ & $14.8 \%$ & $12.5 \%$ & $16.8 \%$ & $15.8 \%$ \\
\hline SRAT oxalate Generation & $45.8 \%$ & $64.0 \%$ & $0.4 \%$ & $44.9 \%$ & $-7.3 \%$ & $22.7 \%$ & $-44.5 \%$ & $4.7 \%$ \\
\hline SRAT formate Generation & NA & NA & NA & NA & NA & NA & NA & NA \\
\hline SME glycolate Destruction & $18.6 \%$ & $14.3 \%$ & $20.3 \%$ & $-2.5 \%$ & $8.7 \%$ & $17.4 \%$ & $16.7 \%$ & $17.3 \%$ \\
\hline SME oxalate Generation & $15.9 \%$ & $17.9 \%$ & $-9.3 \%$ & $-14.0 \%$ & $40.0 \%$ & $10.7 \%$ & $183.5 \%$ & $38.8 \%$ \\
\hline SME formate Generation & $29.0 \%$ & $92.6 \%$ & $-7.3 \%$ & $-2.5 \%$ & $-9.5 \%$ & $-21.5 \%$ & $-33.8 \%$ & $-21.3 \%$ \\
\hline
\end{tabular}

Note: The color shading used in the above table is shown below (green is excellent, yellow is good, red is unacceptable)

\begin{tabular}{|l|l|}
\hline & $+/-10 \%$ \\
\hline & $+/-20 \%$ \\
\hline & $+/-50 \%$ \\
\hline
\end{tabular}

Carbon dioxide $\mathrm{CO}_{2}$ was measured by GC and MS for all runs and by FTIR for some 4-L runs and all 22-L and 220-L runs. Then concentration of carbon monoxide CO was also measured by the FTIR. The total CO measured ranged from 0.04 to $0.17 \%$ of the total $\mathrm{CO}_{2}$ for any given run. Carbon balances were performed using the offgas $\mathrm{CO}_{2}$ concentrations, the glycolic acid addition values, and the SRAT product glycolate analyses. From these balances, the glycolate destruction (\%) was determined for each run. The value from the offgas data should be the same as that from the glycolate data within measurement uncertainty.

Table 3-19 shows the glycolate destruction calculated from the offgas carbon dioxide and from the glycolate measured by the caustic quench (CQ) glycolate method. The caustic quench method uses an addition of $\mathrm{NaOH}$ to raise the $\mathrm{pH}$ of the SRAT or SME product sample to around 11 before dilution and analysis by ion chromatography (IC). The caustic quench method has been recommended for analysis of anions. The offgas $\mathrm{CO}_{2}$ measurements are also subject to uncertainty. The GC/MS ratios of cumulative $\mathrm{CO}_{2}$ ranged from 99.7 to $112.0 \%$, with an average of $104.3 \%$. The GC values have generally been consistently about $5 \%$ higher than the MS values. The FTIR/MS ratios of cumulative $\mathrm{CO}_{2}$ ranged from 96.1 to $101.4 \%$, with an average of 98.6\%. The good agreement between the MS and FTIR values suggests that the $\mathrm{CO}_{2}$ values from the GC are higher than the actual values. This conclusion is supported by the fact that the $\mathrm{O}_{2}+\mathrm{N}_{2}$ values for air from the GC have also been generally higher than they should be by about $5 \%$. For the carbon balances, the MS $\mathrm{CO}_{2}$ values were used, except for run GN76 where there were sampling problems associated with the MS, so the FTIR values were used. 
Table 3-19. Glycolate Destruction from Offgas and Glycolate Measurements* by Acid Stoichiometry

\begin{tabular}{|c|c|c|c||}
\hline Run & $\begin{array}{c}\text { Acid \% } \\
\text { Stoichiometry \& } \\
\text { \% Glycolic }\end{array}$ & $\begin{array}{c}\text { From Totalized } \\
\text { Offgas Carbon }\end{array}$ & $\begin{array}{c}\text { From Glycolate } \\
\text { Analyses (Caustic } \\
\text { Quench) }\end{array}$ \\
\hline GN70 & 10058.3 & $13.7 \%$ & $16.6 \%$ \\
\hline GN76 & 10058.3 & $17.4 \%$ & $16.2 \%$ \\
\hline GN74 & 10054.5 & $13.4 \%$ & $20.5 \%$ \\
\hline GN79 & 10054.5 & $16.8 \%$ & $15.7 \%$ \\
\hline \multicolumn{1}{|c|}{$10 \%$ Runs Mean } & $15.3 \%$ & $17.3 \%$ \\
\hline GN73 & 11052.2 & $10.9 \%$ & $19.6 \%$ \\
\hline GN75 & 11052.2 & $11.7 \%$ & $16.4 \%$ \\
\hline GN77 & $110 \quad 52.2$ & $15.1 \%$ & $13.3 \%$ \\
\hline GN78 & $110 \quad 52.2$ & $14.9 \%$ & $16.5 \%$ \\
\hline \multicolumn{2}{|c|}{$\mathbf{1 1 0} \%$ Runs Mean } & $\mathbf{1 3 . 2 \%}$ & $\mathbf{1 6 . 5 \%}$ \\
\hline GN71 & 125 & $10.1 \%$ & $19.9 \%$ \\
\hline \multicolumn{2}{|c|}{ Mean of All Tests } & $\mathbf{1 3 . 8 \%}$ & $\mathbf{1 7 . 2 \%}$ \\
\hline
\end{tabular}

Blue: 4-L runs Italics: not a scaled run *SRAT measurement

In Table 3-19, the glycolate destruction values are shown arranged by acid stoichiometry. For the $110 \%$ stoichiometry runs, the average glycolate destruction was 13.2\% from the offgas measurements and $16.5 \%$ from the glycolate analyses. The $100 \%$ stoichiometry values from the offgas were higher at $15.9 \%$ for the scaled runs and $15.3 \%$ for all four $100 \%$ runs. The values from the glycolate analyses were 17.5 and $17.3 \%$. The averages for all runs including the GN71 125\% acid run were 13.8\% from the offgas and 16.8\% from the glycolate analyses. Table 3-20 shows the effect of glycolate analytical uncertainty on the glycolate destruction value for run GN75. A low assumed analytical uncertainty of $\pm 5 \%$ almost encompasses the measured offgas value of $11.7 \%$ destruction; a more often assumed uncertainty of $\pm 10 \%$ includes the offgas value. Therefore, the values from the offgas and the glycolate analyses are the same within the glycolate analysis uncertainty; note that there is also offgas measurement uncertainty that is not included.

Table 3-20. Effect of Uncertainty on Glycolate Destruction Calculated from Glycolate Analyses

\begin{tabular}{|r|c|c|c|c|c||}
\hline & $\mathbf{- 1 0 \%}$ & $\mathbf{- 5 \%}$ & Measured & $\mathbf{+ 5 \%}$ & $\mathbf{+ 1 0 \%}$ \\
\hline SRAT Product Glycolate Measured (mg/kg) & 44,600 & 47,100 & 49,600 & 52,100 & 54,600 \\
\hline Glycolate Destruction from Measured (\%) & $24.8 \%$ & $20.6 \%$ & $16.4 \%$ & $12.3 \%$ & $8.1 \%$ \\
\hline Glycolate Destruction from Offgas (\%) & \multicolumn{5}{|c|}{$11.7 \%$} \\
\hline
\end{tabular}

These same data are shown arranged by scale in Table 3-21. Although the offgas and measured glycolate values are within analytical uncertainty, there does appear that there may have been a systematic difference between these values for the 4 - $\mathrm{L}$ runs. The offgas average was $12.4 \%$ versus $18.3 \%$ from the glycolate measurement. 
Table 3-21. Glycolate Destruction from Offgas and Glycolate Measurements* by Scale

\begin{tabular}{||c|c|c|c|}
\hline Run & $\begin{array}{c}\text { Acid \% } \\
\text { Stoichiometry }\end{array}$ & $\begin{array}{c}\text { From Totalized } \\
\text { Offgas Carbon }\end{array}$ & $\begin{array}{c}\text { From Glycolate } \\
\text { Analyses (Caustic } \\
\text { Quench) }\end{array}$ \\
\hline GN70 & 100 & $13.7 \%$ & $16.6 \%$ \\
\hline GN74 & 100 & $13.4 \%$ & $20.5 \%$ \\
\hline GN73 & 110 & $10.9 \%$ & $19.6 \%$ \\
\hline GN75 & 110 & $11.7 \%$ & $16.4 \%$ \\
\hline & $\mathbf{4 - L}$ Scale Mean & $\mathbf{1 2 . 4 \%}$ & $\mathbf{1 8 . 3 \%}$ \\
\hline GN76 & 100 & $17.4 \%$ & $16.2 \%$ \\
\hline GN79 & 100 & $16.8 \%$ & $15.7 \%$ \\
\hline GN77 & 110 & $15.1 \%$ & $13.3 \%$ \\
\hline GN78 & 110 & $14.9 \%$ & $16.5 \%$ \\
\hline & Large Scale Mean & $\mathbf{1 6 . 0} \%$ & $\mathbf{1 5 . 4 \%}$ \\
\hline
\end{tabular}

The concentration of HMDSO was measured by FTIR in the 4-L runs GN71, 73, and 75, and in all of the 22-L and 220-L runs. It was not measured in GN70, 72, and 74 because the FTIR could only analyze one of the two concurrent 4-L runs. A typical plot of the concentration of HMDSO versus time is shown in Figure 3-12 for run GN77. Both the concentration from the FTIR and a qualitative measure of the HMDSO from the MS (not calibrated for HMDSO, units arbitrary) at m/z 147 is also shown. The peak location agreement indicates the correct identification of HMDSO. 


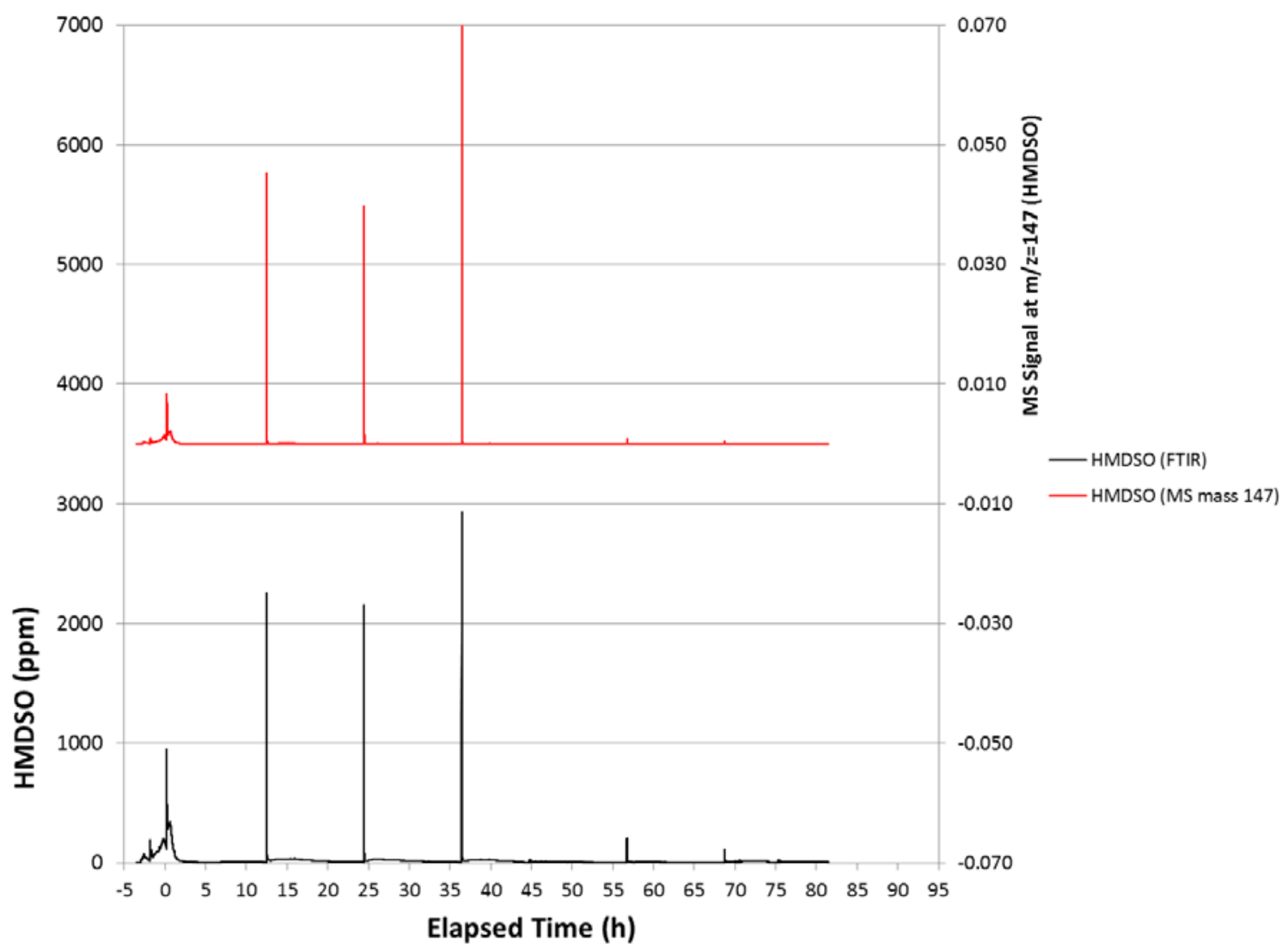

Figure 3-12. SRAT and SME Cycle HMDSO Concentration for GN77

\subsubsection{Mercury Chemistry Balance}

The reduction, stripping, condensation and decanting of mercury from the slurry are completed in the SRAT, SME, SRAT condenser, SMECT, FAVC, and MWWT. If the mercury is not collected in the MWWT, the mercury will accumulate in other equipment, be fed to the melter, sent back to the tank farm as recycle or exit DWPF through the stack. So, it is imperative that as much mercury can be collected in the MWWT and SMECT as feasible to minimize impacts to DWPF and the tank farm.

The DWPF SRAT product mercury target is $\leq 0.45 \mathrm{wt} \%$ total solids (approximately 1,200 mg $/ \mathrm{kg}$ in SRAT product). The starting sludge mercury in this testing was $3,720 \mathrm{mg} / \mathrm{kg}$. Thus approximately two-thirds of the mercury must be removed to achieve this limit. Any mercury not removed in the MWWT will likely be returned to the tank farm through the recycle stream.

\subsubsection{Mercury Reduction}

The mercury is easily reduced from HgO to elemental mercury by the glycolic acid. This was demonstrated in simulant studies with an SB6 supernate simulant with added HgO. The HgO reduced to elemental mercury very quickly (no longer than a minute). In all of our studies, it is apparent that the mercury is completely reduced. A possible reaction for mercuric oxide to be reduced by glycolic acid to form $\mathrm{CO}_{2}$ is:

$$
3 \mathrm{HgO}+\mathrm{C}_{2} \mathrm{H}_{4} \mathrm{O}_{3} \rightarrow 3 \mathrm{Hg}^{0}+2 \mathrm{CO}_{2}+2 \mathrm{H}_{2} \mathrm{O}
$$




\subsubsection{Mercury Steam Stripping}

Mercury reduction and stripping are required to collect the mercury in the MWWT. Mercury reduction occurs very quickly during glycolic acid addition in the SRAT. The starting mercury concentration in the sludge is calculated to be $3,720 \mathrm{mg} / \mathrm{kg}$. By the time acid addition is complete, the measured mercury in the sludge is below $500 \mathrm{mg} / \mathrm{kg}$ in $100 \%$ stoichiometry runs and below 2,000 mg/kg in $110 \%$ stoichiometry runs. Note that this is much lower than could be accomplished by steam stripping (virtually none should have been removed by this time). This is evidence that the mercury is not well mixed in the SRAT and some has likely settled to the bottom of the vessel.

Mercury stripping removes mercury from the SRAT due to the vapor pressure of mercury at boiling. Mercury vapor is part of the offgas stream and it takes about $250 \mathrm{~g}$ water vapor to remove $1 \mathrm{~g}$ of mercury from the SRAT. In practice, mercury stripping is less efficient than this and it may take 2-3 times this amount of steam to effectively remove the mercury (and as the mercury concentration drops, the stripping efficiency drops). A line showing the expected stripping line assuming it takes $750 \mathrm{~g}$ steam to remove a $\mathrm{g}$ of mercury is shown on each graph showing the SRAT mercury concentration versus time. Based on these graphs, the steam stripping was much faster than theoretical. The mercury sample results are summarized in Figure 3-13 and Figure 3-14.

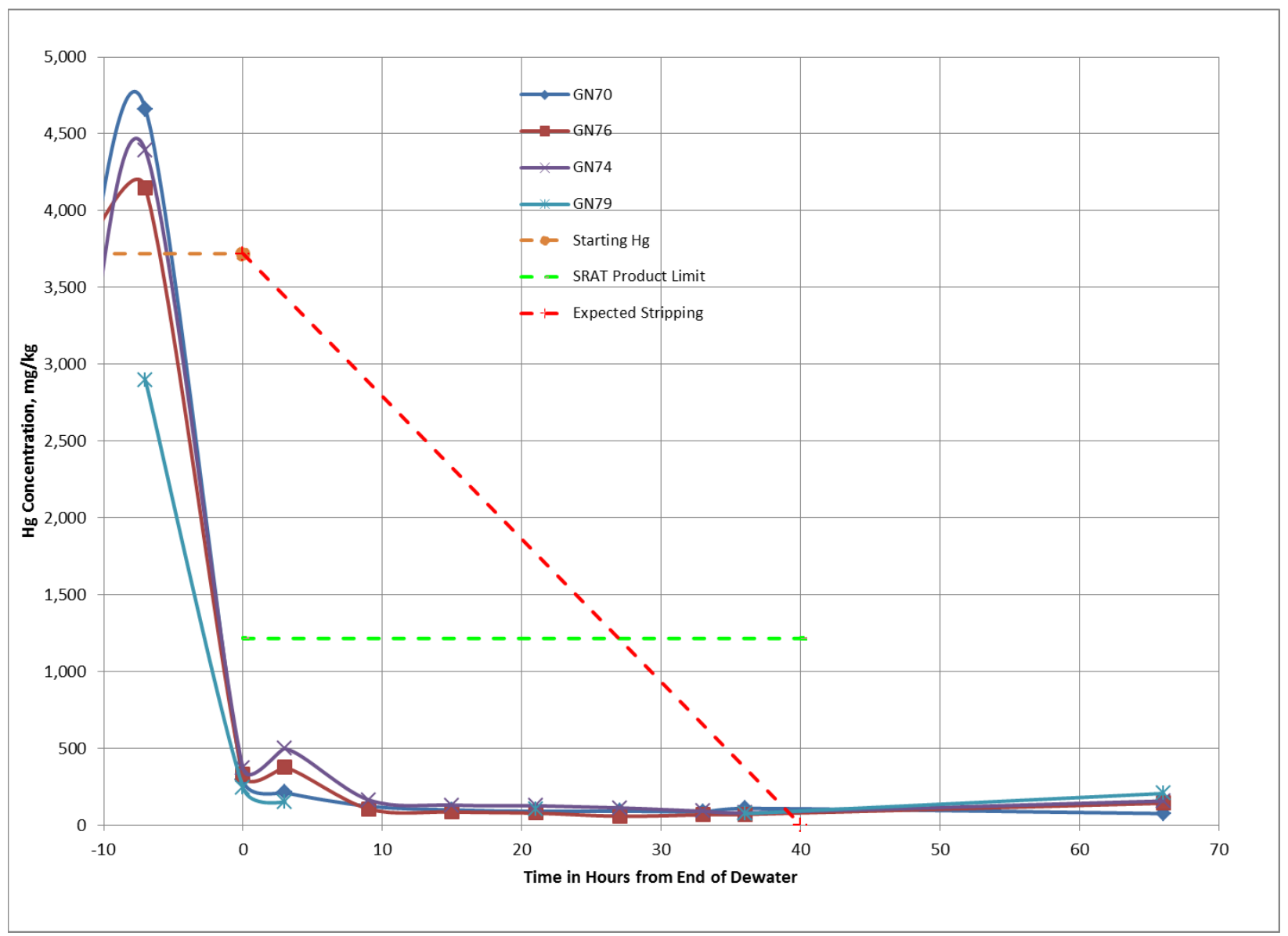

Figure 3-13. GN70, GN74, GN76, GN79 Mercury Concentration in Slurry Samples, mg/kg 


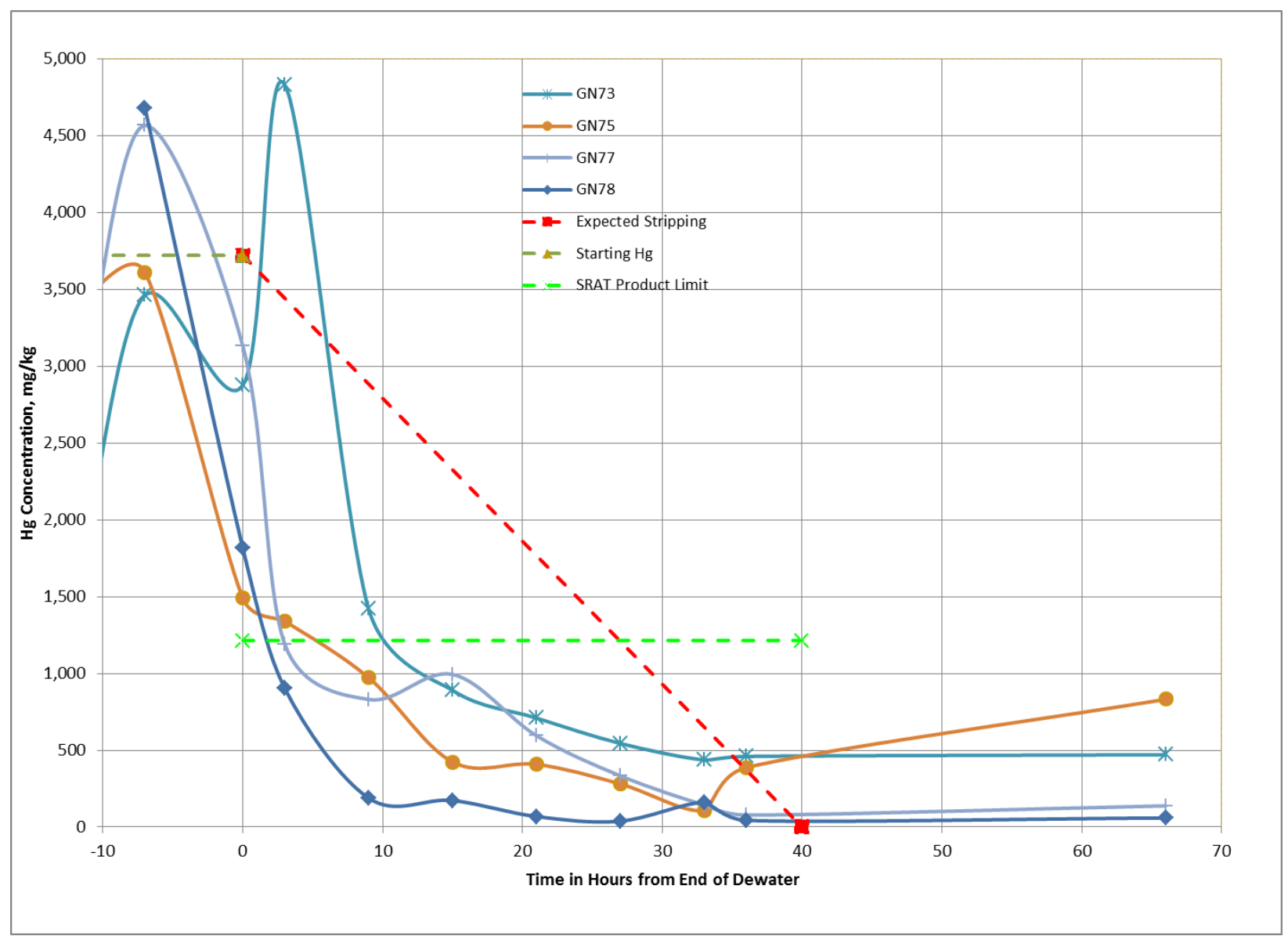

Figure 3-14. GN73, GN75, GN77 and GN78 Mercury Concentration in Slurry Samples, mg/kg

\subsubsection{Mercury Collection in MWWT}

Once the mercury has been reduced, steam stripped, and condensed, it still must reach the MWWT to be collected. Little is known about the mercury condensing as the mercury concentration in vapor is too low for detection and would likely be removed in the SRAT condenser, ammonia scrubber or FAVC. What should happen is that the dense liquid mercury coalesces, drops to the MWWT and settles in the bottom of the MWWT. In practice, the mercury can condense in the offgas lines or condenser and likes to coat metal surfaces. In addition, the mercury doesn't always coalesce, there seems to be more black looking mercury (small particles of elemental $\mathrm{Hg}$ ) than shiny beads of $\mathrm{Hg}$.

A mass balance was attempted to determine what is happening to the mercury during processing. In the 4$\mathrm{L}$ and 22-L runs, no attempt was made to clean the vessels and completely close the mercury balance. The only two measured mercury sources were the mercury collected in the MWWT and the mercury present in the SME product as measured from an aqua regia digested sample. In most runs, $20-50 \%$ of the mercury was collected from the MWWT after the SRAT cycle was complete (Table 3-22). Mercury collection was much lower for the $100 \%$ acid stoichiometry runs than the $110 \%$ acid stoichiometry runs. The one $125 \%$ acid stoichiometry run had 37.9\% of the potential Hg collected in the MWWT (similar to the 110\% runs). The $110 \%$ acid stoichiometry runs had higher mercury recovery than the SB8 simulant runs (120-125\% stoichiometry nitric-formic acid flowsheet), which recovered between 21 and $28 \%$ of the mercury ${ }^{9}$. 
Table 3-22. Elemental Mercury Collected

\begin{tabular}{||l|c|c|c|c||c||c|c|c|c||}
\hline \hline Acid Stoichiometry & \multicolumn{4}{|c||}{$100 \%$} & \multicolumn{4}{c||}{ 110\% } \\
\hline Run & GN70 & GN76 & GN74 & GN79 & & GN73 & GN75 & GN77 & GN78 \\
\hline Acid Ratio, Glycolic:Total & 0.5831 & 0.5831 & 0.5454 & 0.5454 & & 0.5221 & 0.5221 & 0.5221 & 0.5221 \\
\hline Mercury Added, g & 12.88 & 74.6 & 12.87 & 572 & & 12.87 & 12.87 & 67.3 & 487 \\
\hline MWWT Hg Recovered, g & 2.40 & 14.6 & 2.54 & 83.2 & & 4.7 & 6.1 & 7.0 & 145 \\
\hline \% collected in MWWT & 18.6 & 19.5 & 19.7 & 14.5 & & 36.7 & 47.3 & 10.5 & 39.1 \\
\hline
\end{tabular}

Photos were taken throughout runs GN78 and GN79. Several photos showing the change in color of the condensate, the collection of black mercury particles on the glassware, and the collected mercury in the MWWT are shown in Figure 3-15, Figure 3-16, and Figure 3-17. Note also there is more mercury collected in GN78 than GN79.

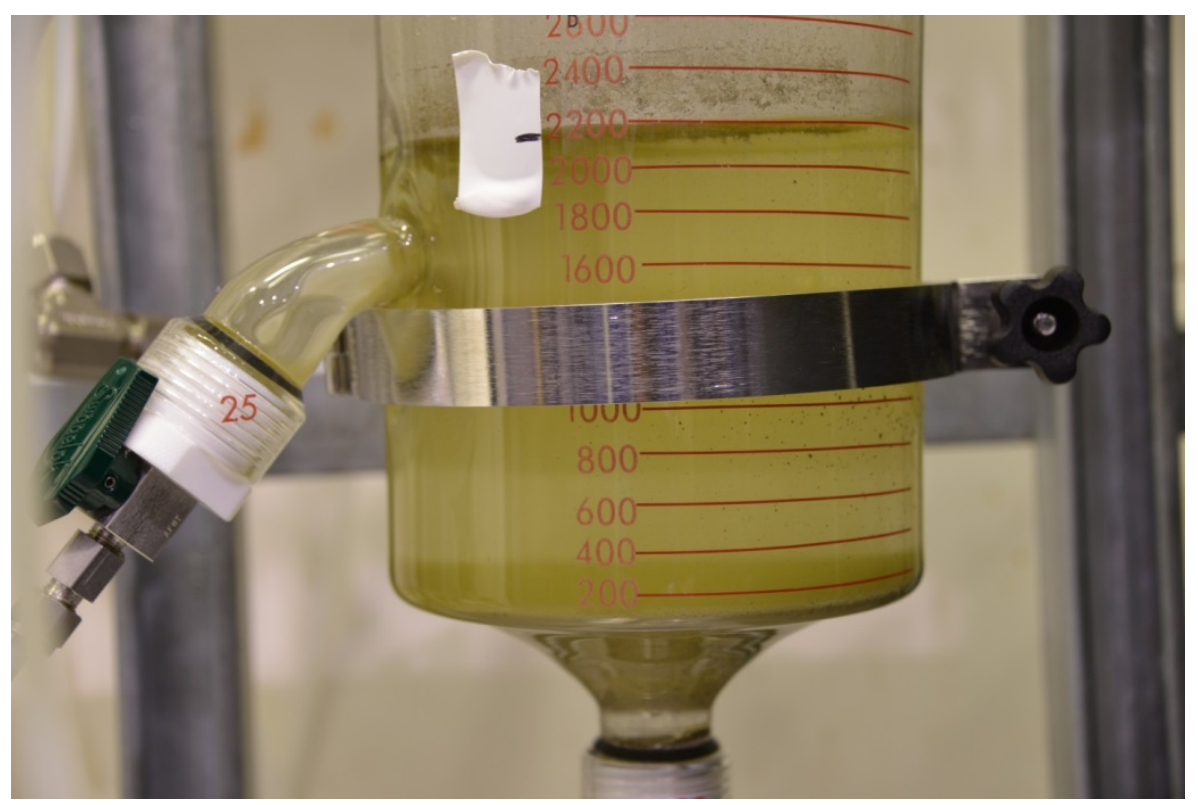

Figure 3-15: GN78-110 Mercury collection in the MWWT (four hours into SRAT reflux) 
SRNL-STI-2014-00306

Revision 0

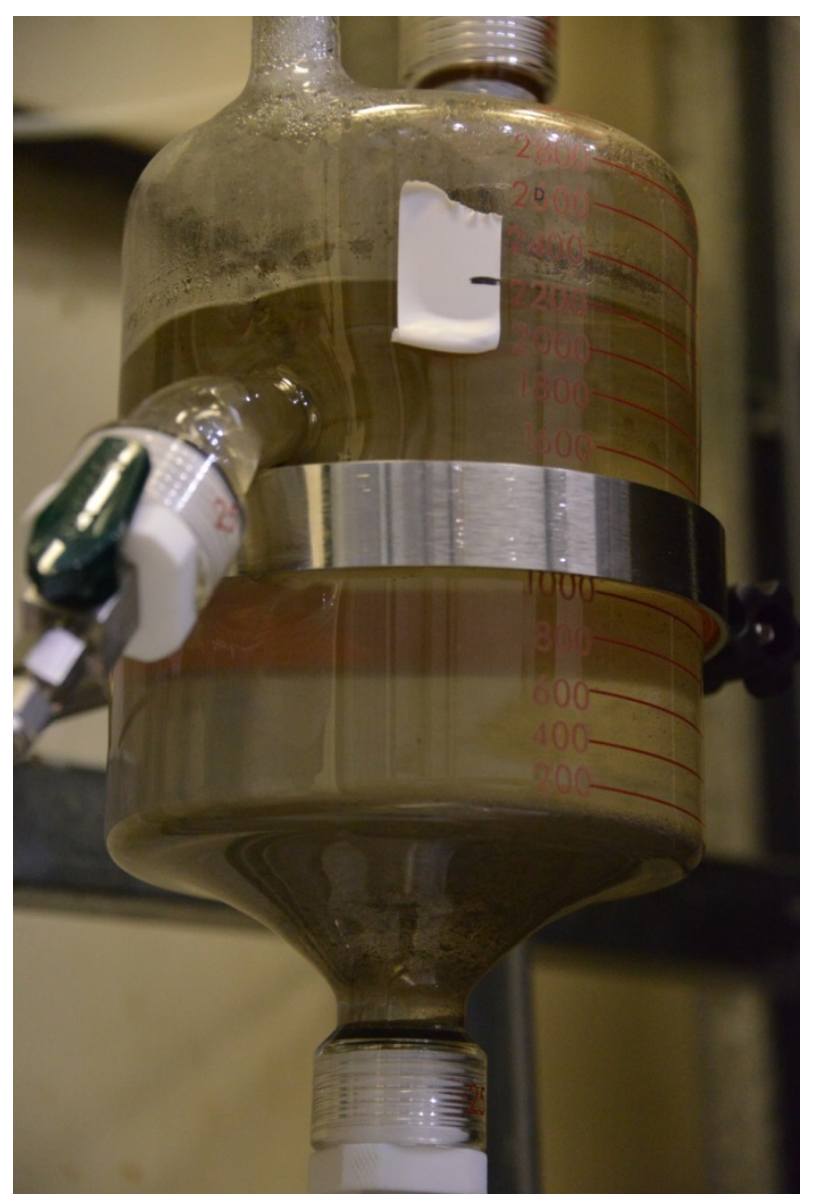

Figure 3-16: GN78-110 Mercury collection in the MWWT (28 hours into SRAT reflux) 


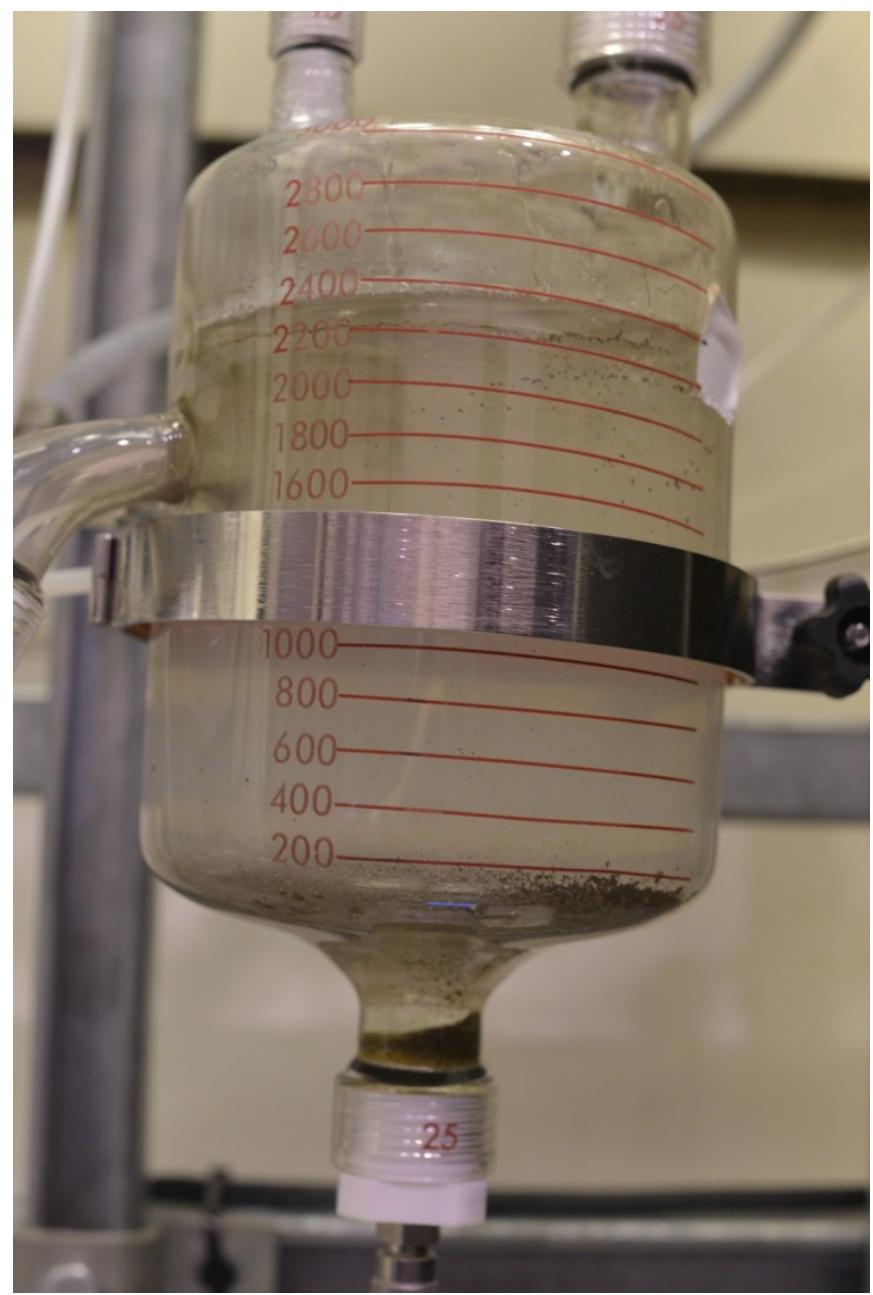

Figure 3-17: GN79-100 Mercury collection in the MWWT (32 hours into SRAT reflux)

In the 220-L runs, the mercury balance is easier as more $\mathrm{Hg}$ is present. Elemental mercury was collected from each vessel and weighed. In addition, virtually every component was rinsed with $10.7 \mathrm{M}$ nitric acid in an attempt to close the mercury balance. In addition, the SME product was dried and as much mercury was recovered as feasible.

An extensive effort was completed to close the mercury balance in runs GN78 and GN79. The mercury mass balance is summarized in Table 3-23. In addition to the mercury that drained from the MWWT into the sample bottle at the completion of the SRAT cycle, other mercury was recovered once the SME cycle was complete. Elemental Hg was recovered from the SRAT/SME vessel, the SRAT/SME condenser, and the MWWT. Much more mercury was recovered from run GN78. Note that about two-thirds of the mercury was recovered as elemental mercury in run GN78. Note that 35\% of the elemental mercury was found in the SRAT/SME vessel after the SME cycle was complete. 
Table 3-23. Mercury Mass Balance Summary

\begin{tabular}{|c|c|c|}
\hline Acid Stoichiometry & $110 \%$ & $100 \%$ \\
\hline Run & GN78 & GN79 \\
\hline HgO Added, g & 525.90 & 617.20 \\
\hline Hg Added, g & 487.05 & 571.61 \\
\hline MWWT Hg, g & 190.33 & 83.17 \\
\hline Post SRAT Elemental Hg, g & 145.00 & 77.49 \\
\hline Post SRAT Acid Rinse Hg, g & 44.93 & 0.21 \\
\hline Post SME Elemental Hg, g & NA & 5.47 \\
\hline Post SME Acid Rinse Hg, g & 0.40 & 0.00 \\
\hline Post SME Vessel Mercury, g & 122.64 & 91.70 \\
\hline Elemental Hg, g & 114.96 & 61.05 \\
\hline Acid Rinse Hg, g & NA & $* 0.00$ \\
\hline Hg in SME product, g & 7.68 & 30.65 \\
\hline Condenser Hg, g & 121.37 & 31.28 \\
\hline Elemental Hg & 21.36 & 17.63 \\
\hline Post SRAT Acid Rinse Hg, g & 100.00 & 13.64 \\
\hline Post SME Acid Rinse Hg, g & 5.46 & $* 0.00$ \\
\hline Ammonia Scrubber Hg, g & 2.65 & 0.91 \\
\hline Scrub Solution Hg, g & 0.26 & 0.91 \\
\hline Scrubber Acid Rinse Hg, g & 0.15 & 0.00 \\
\hline Packing Acid Rinse Hg, g & 2.39 & $0.00 *$ \\
\hline Offgas Tubing Acid Rinse & 2.42 & 13.64 \\
\hline Condensate Hg, g & 11.51 & 8.98 \\
\hline SRAT Condensate Hg, g & 11.51 & 8.98 \\
\hline SME Condensate Hg, g & 0.00 & 0.00 \\
\hline Other (composite) & NA & $130.44^{*}$ \\
\hline Total & 450.91 & 346.47 \\
\hline \% Recovered & $92.6 \%$ & $60.6 \%$ \\
\hline
\end{tabular}

* Several Streams were combined and analyzed as "Other"

\subsubsection{4-L MWWT Equipment}

During SRAT boiling, mercury was collected in the MWWT. The mercury typically had a dark blackish color and was observed both floating on the water surface and at the bottom of the MWWT. A photo of the 4-L MWWT is shown in Figure 3-18. Note also that the mercury coated the glass tubing between the condenser and the MWWT. 


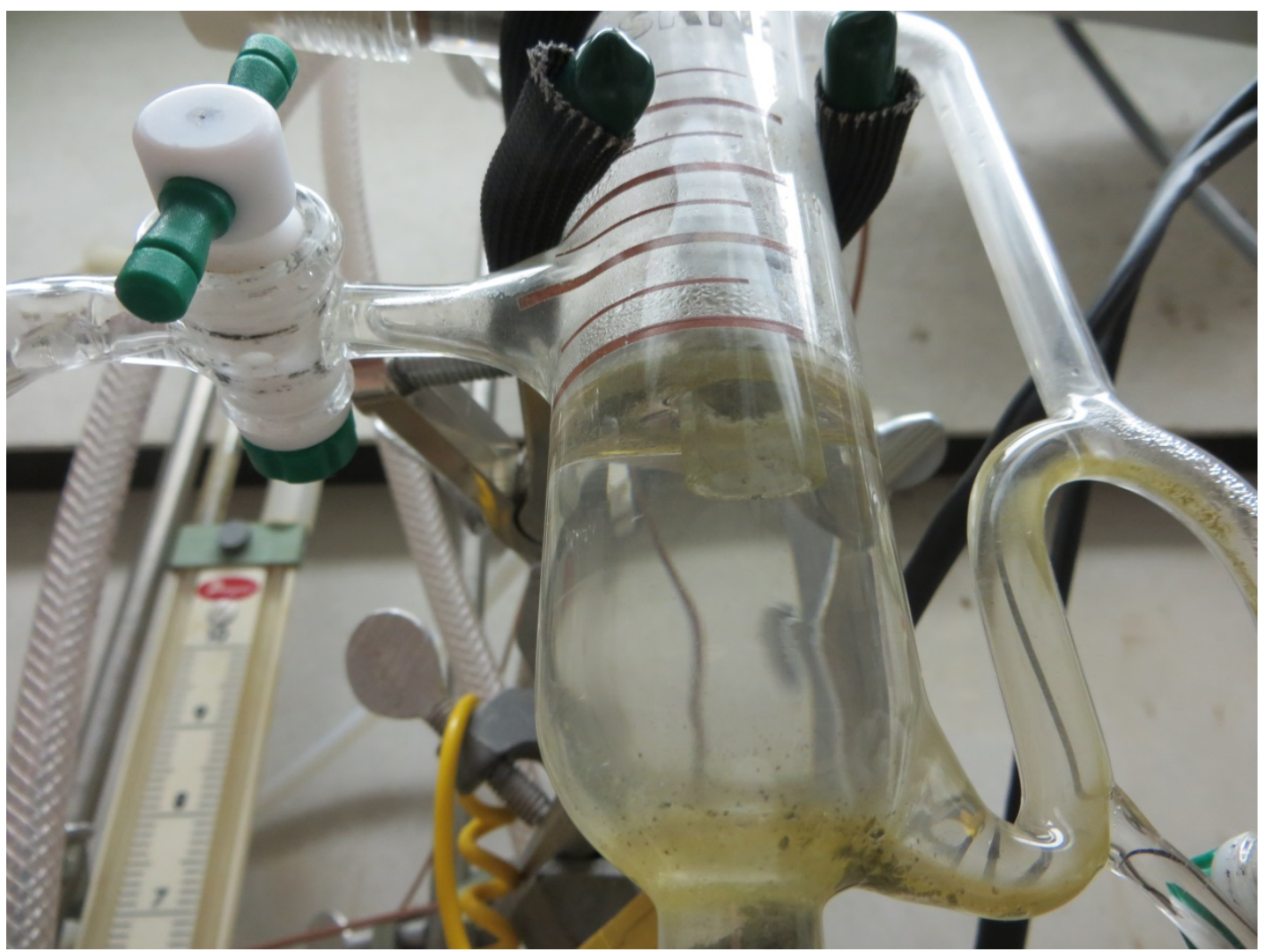

Figure 3-18: Mercury Observed in the 4-L MWWT

\subsubsection{MWWT Operation}

Mercury has become an important issue throughout the High Level Waste (HLW) Processing Facilities due to the high concentrations of mercury found in Tank 22 (the DWPF recycle tank), Tank 51 (Sludge Preparation Tank), Tank 50 (Saltstone Feed Tank), and the high mercury recovery in HLW evaporators. DWPF was designed as the purge point for mercury in the HLW system, with an assumed mercury recovery of $75 \%$. Based on a DWPF Engineering mass balance ${ }^{24}$, roughly $82 \%$ of the mercury is returned to the Tank Farm and little mercury is collecting in the MWWT, SRAT or SMECT based on recent analyses of DWPF samples. ${ }^{25}$ The discussion in this section will focus on the results of this testing as compared to DWPF processing, speculation as to why mercury is not accumulating in the MWWT and is instead being returned to the tank farm, and suggestions for testing that might be performed to improve $\mathrm{Hg}$ retention in DWPF. This discussion applies to both the nitric-formic and the nitric-glycolic acid flowsheet.

The MWWT is essentially a mercury decanter. Mercury, the dense phase should accumulate in the lower portion of the MWWT and the condensate, the light phase, will either be returned to the SRAT (during reflux stage) or sent to the SMECT (during dewater stages). As in any decanter, dense liquids and solids will collect in the bottom, including sludge solids. An ideally designed decanter would be very still and have no chemical reactions unlike the DWPF decanter where there is a continuous flow of condensate dropping into the decanter and where gases are being generating due to reactions (see mercury dissolving in nitric acid in video by searching for mercury and dilute nitric acid). Note that the MWWT is not designed to be a very efficient decanter as the density difference between mercury and the condensate is at least 12x, so it had to fit into the remaining space in the CPC. Mercury accumulated in other places such as the 220-L SRAT condenser bottom cap (elemental Hg, Figure 3-19). In order to help improve the mercury balance accuracy, the MWWT and bottom cap of the SRAT condenser were replaced at the end of the 
SRAT cycle. This prevented mercury reduced in the SRAT cycle from being accounted for in the SME cycle.

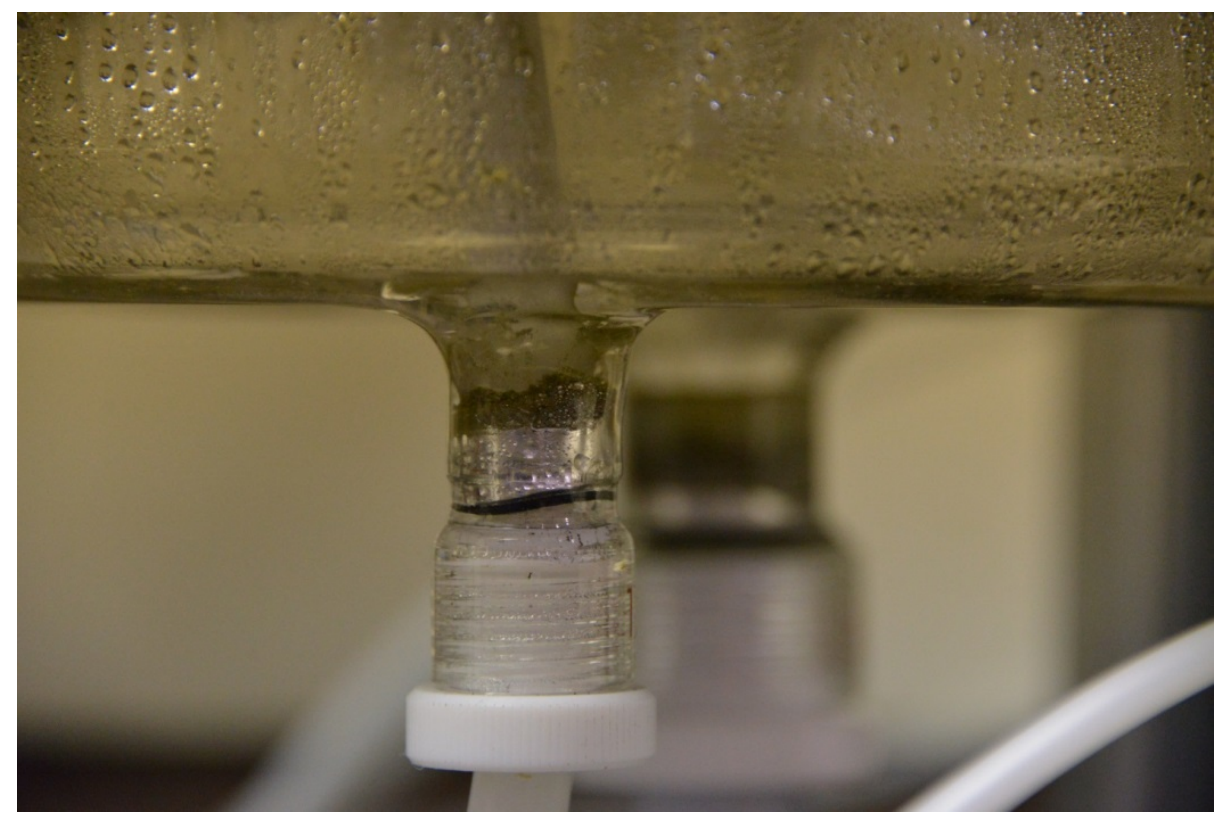

Figure 3-19: Mercury collection in the 220-L SRAT condenser

The MWWT for the 220-L rig was volumetrically scaled from DWPF. The 4-L and 22-L MWWT were not. There are also some operational differences between the scaled MWWTs and the DWPF MWWT. Other than scaling, the most significant difference is that the DWPF MWWT begins a new batch with the same mercury and condensate as the previous batch. The mercury, often very fine droplets from the previous batch, may also have collected in the offgas piping, SMECT, the SRAT or SME scrubber, the SRAT condenser or the piping between the condenser and MWWT. The scaled decanters (and other equipment) started mercury free with DI water added to the MWWT but no mercury or sludge solids.

Based on our testing, the MWWT condensate at the beginning of a new SRAT cycle should be near neutral with very few anions or cations, a little dissolved mercury. A graph showing the nitrate and $\mathrm{pH}$ during the period from 2 hours before the end of acid addition and 10 hours into boiling is shown in Figure 3-20. Note the $\mathrm{pH}$ is very low $(0.28)$ and the nitrate is very high $(52,000 \mathrm{mg} / \mathrm{L}$ or $0.84 \mathrm{M})$ at the completion of acid addition and for the first 3 hours of dewater. By the time dewater is complete ( $\sim 7$ hours after the end of acid addition), the nitrate was close to zero and $\mathrm{pH}$ is climbing. Note also that the nitrate is higher and $\mathrm{pH}$ is lower for the higher acid stoichiometry experiments. By the time the SRAT cycle is complete, the $100 \%$ acid stoichiometry had climbed to almost 7 ; the $110 \%$ stoichiometry had climbed to 4 , while the $125 \%$ stoichiometry $\mathrm{pH}$ remained at approximately 3 . The $\mathrm{pH}$ data for all runs is summarized in Figure 3-21. 
SRNL-STI-2014-00306

Revision 0

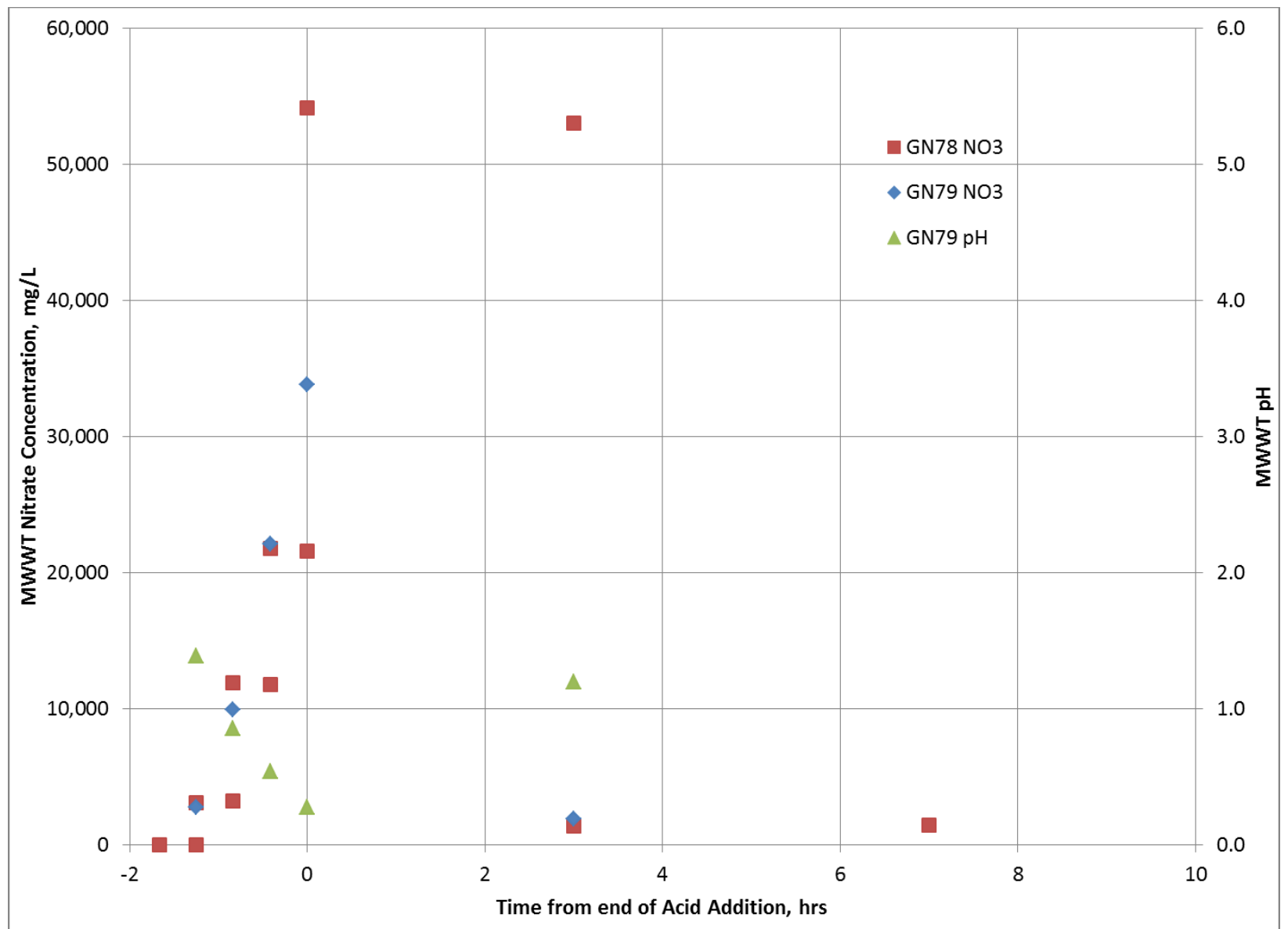

Figure 3-20. GN 78 and GN79 MWWT Aqueous Nitrate, mg/L and GN79 pH 


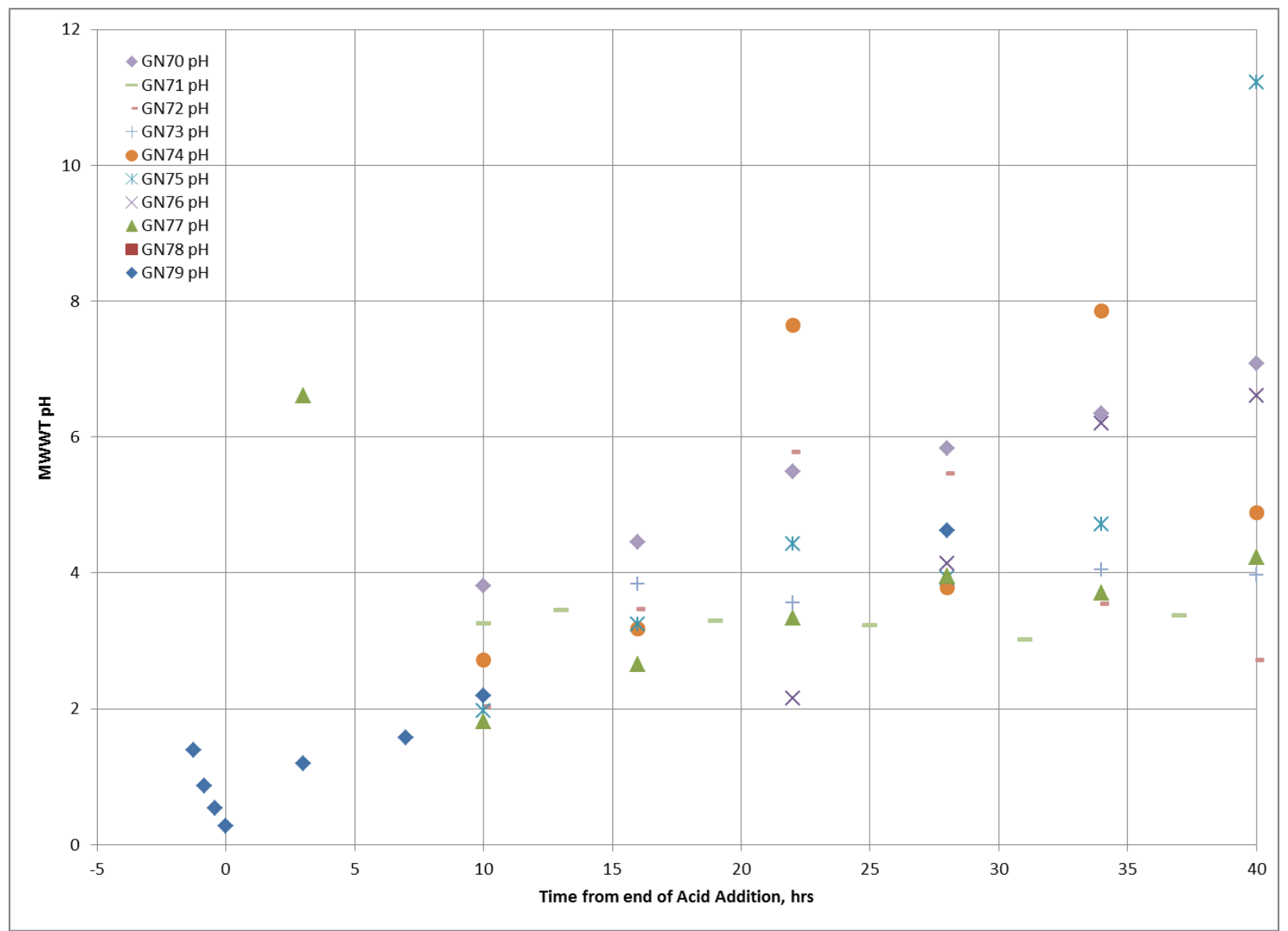

Figure 3-21. GN70-GN79 MWWT Aqueous pH

What this means for DWPF is that a hot (DWPF's condensate temperature often is $>50{ }^{\circ} \mathrm{C}$ ), concentrated nitric acid solution is being condensed in the SRAT condenser and drains to the MWWT. This is an ideal solution for dissolving elemental mercury, especially the fine particles. Any mercury that is dissolved in the offgas piping, condenser or MWWT during this stage will drain to the MWWT and be transferred to the SMECT. If this is happening, the mercury concentration should be highest in the SMECT during the first few hours of SRAT dewater. The dissolved mercury concentration of the MWWT is shown in Figure 3-22. In hindsight, more frequent MWWT samples should have been pulled during SRAT dewater. 


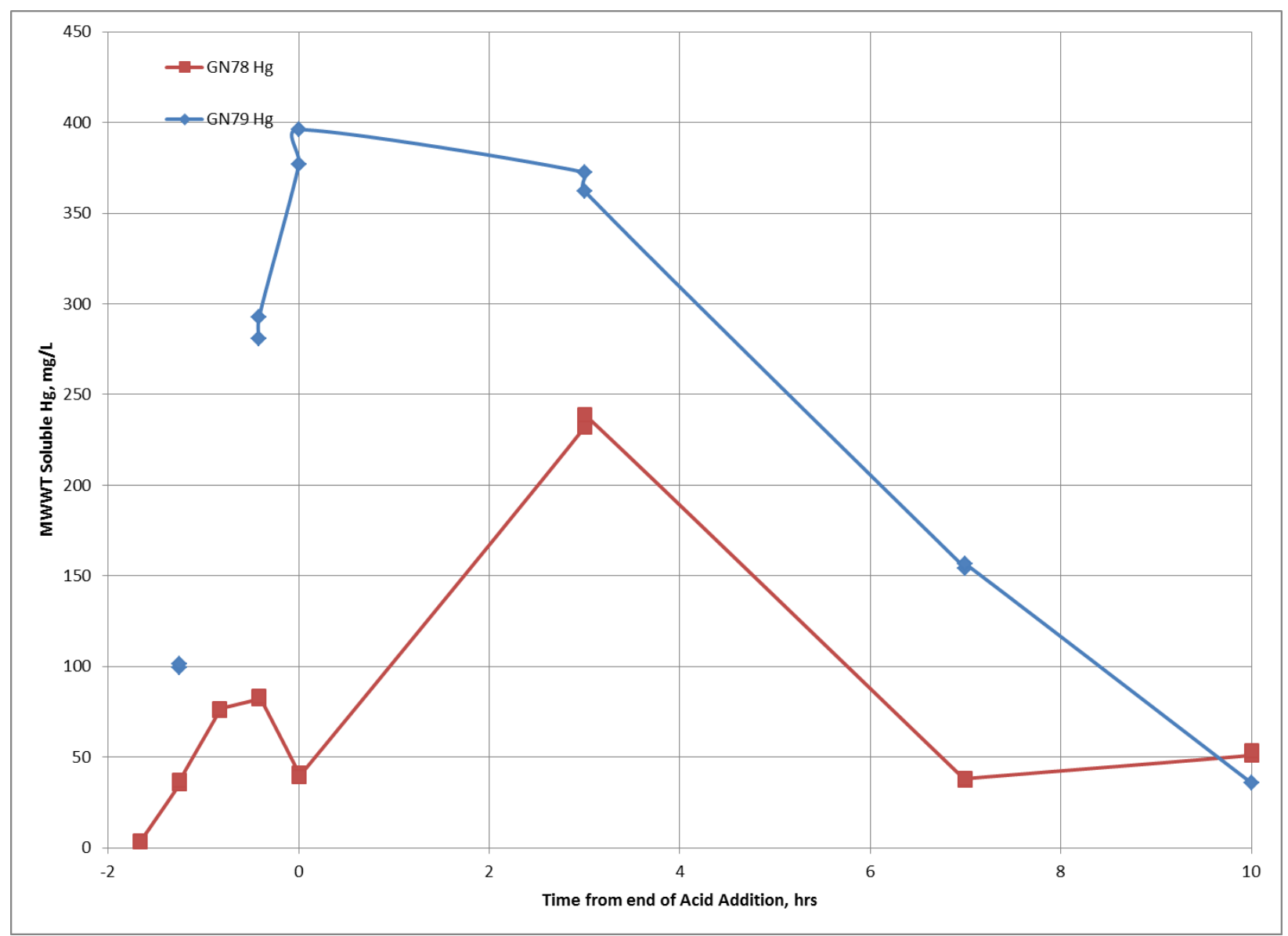

Figure 3-22. GN78 and GN79 MWWT Aqueous Dissolved Mercury Concentration, mg/L

In the scaled demonstration runs at design basis steam flow, there may not have been enough mercury in the condenser, MWWT, etc. to lead to higher mercury dissolution. Using the maximum MWWT dissolved mercury result ( $235 \mathrm{mg} / \mathrm{L}$ ) would only lead to dissolving $2 \%$ of the mercury over the seven hour dewater period. If the MWWT had started with elemental mercury, like DWPF likely does, more mercury dissolution might have been accomplished.

What can be done to improve future experiments for understanding mercury stripping, mercury dissolution and mercury decanting? Some suggestions are listed below:

- Determine the forms of mercury produced in CPC processing (elemental mercury, calomel, methyl mercury, etc.).

- Determine the fraction of soluble and insoluble mercury species.

- Complete back to back DWPF prototypic SRAT testing that includes a heel of mercury in the MWWT and SMECT, hot SRAT condenser outlet temperature, mercury in offgas piping, SRAT condenser, and tubing between SRAT condenser and MWWT to better simulate current DWPF processing. Pull more samples during the latter part of glycolic acid addition and the early part of SRAT dewatering.

- Determine if mercury collection is increased by refluxing the SRAT condensate (not dewatering) for the first 3 hours of SRAT boiling. This would return any dissolved mercury back to the SRAT allowing collection in the MWWT at a time when the condensate is less acidic.

- Determine whether $\mathrm{pH}$ control of the MWWT can increase mercury recovery. 
- Determine whether $\mathrm{pH}$ control of the SMECT can increase mercury recovery.

- Determine whether a coalescer will improve the recovery of mercury in the MWWT.

- Complete SME cycles with a MWWT to attempt to quantify the mercury stripped during the SME cycle. Note that in DWPF, elemental mercury will be steam stripped and collected in the SMECT. A low pH SMECT is likely to reoxidize and dissolve the Hg, so it likely will not accumulate in the SMECT unless the $\mathrm{pH}$ is increased.

- Determine the rate of dissolution of elemental mercury by nitric acid in the SMECT.

What changes can be made in DWPF processing for improving mercury stripping and mercury decanting while minimizing mercury dissolution? Some suggestions are listed below:

- Transfer the mercury out of the MWWT and SMECT after each SRAT batch.

- Consider discontinuing nitric acid addition to the SMECT, except for cleaning of SMECT and scrubbers.

- Consider maintaining the SMECT pH at 5 to 6 to minimize dissolution of mercury in SMECT.

- During the periods of high nitric acid formation from $\mathrm{NO}_{\mathrm{x}}$, reflux instead of concentrate so that the condensate is returned to the SRAT instead of the SMECT.

\subsubsection{Hydrogen Generation}

The hydrogen measured throughout the SRAT and SME cycles was very low in all the runs (except in Run GN71 during rod fouling). The hydrogen was measured by both GC and MS but only the GC values are reported below. Since most of the hydrogen readings in all of the runs were less than the detection limit of about 0.03 volume \%, the number of detectable $\mathrm{H}_{2}$ values and the \% of detectable $\mathrm{H}_{2}$ values are recorded in the table below. In most cases, the peak hydrogen value was near the initiation of boiling or just after an antifoam addition. The peak happens here as foam can trap hydrogen and the hydrogen is released as the foam is broken after the antifoam is added. The data is summarized in Table 3-24. Note that the SRAT purge for the nitric-glycolic acid flowsheet is about a third of the formic flowsheet so if the current DWPF purge were used in these experiments, the peak concentrations would be about one-third those reported in the table below. 
SRNL-STI-2014-00306

Revision 0

Table 3-24. Maximum Concentrations of Hydrogen Measured by GC and MS

\begin{tabular}{|c|c|c|c|c|c|c|c|c|c|}
\hline Acid Stoichiometry & \multicolumn{4}{|c|}{$100 \%$} & $125 \%$ & \multicolumn{4}{|c|}{$110 \%$} \\
\hline Run & GN70 & GN74 & GN76 & GN79 & GN71 & GN73 & GN75 & GN77 & GN78 \\
\hline SRAT Scale & 7,541 & 7,541 & 1,317 & 170 & 7,541 & 7,541 & 7,541 & 1,443 & 199 \\
\hline SME Scale & 9,504 & 9,504 & 1,690 & 187 & 9,504 & 9,504 & 9,504 & 1,783 & 222 \\
\hline Acid Ratio, Glycolic: total & 0.5831 & 0.5454 & 0.5831 & 0.5454 & 0.5499 & 0.5221 & 0.5221 & 0.5221 & 0.5221 \\
\hline SRAT hydrogen limit, lb/hr & \multicolumn{9}{|c|}{0.65} \\
\hline SME hydrogen limit, lb/hr & \multicolumn{9}{|c|}{0.223} \\
\hline GC Quantification Limit, vol \% & \multicolumn{3}{|c|}{0.006} & 0.018 & \multicolumn{4}{|c|}{0.006} & 0.018 \\
\hline SRAT GC peak $\mathrm{H}_{2}$, vol. \% & 0.0114 & $<0.006$ & $<0.006$ & $<0.018$ & 0.380 & $<0.006$ & $<0.006$ & $<0.006$ & $<0.018$ \\
\hline SME GC Peak $\mathrm{H}_{2}$, vol. \% & 0.0069 & $<0.006$ & $<0.006$ & 0.0306 & $<0.006$ & $<0.006$ & $<0.006$ & $<0.006$ & 0.020 \\
\hline SRAT GC Peak, lb/hr DWPF & 0.0042 & $<0.0018$ & $<0.0018$ & $<0.0053$ & 0.140 & $<0.0018$ & $<0.0018$ & $<0.0018$ & $<0.0053$ \\
\hline SME GC Peak, lb/hr DWPF & 0.0022 & $<0.0018$ & $<0.0018$ & 0.0072 & $<0.0018$ & $<0.0018$ & $<0.0018$ & $<0.0018$ & 0.0049 \\
\hline MS Quantification Limit, vol \% & \multicolumn{9}{|c|}{0.015} \\
\hline SRAT MS Peak $\mathrm{H}_{2}$, vol. \% & 0.0193 & $<0.015$ & NA & $<0.015$ & 0.356 & 0.023 & $<0.015$ & 0.054 & 0.030 \\
\hline SME MS Peak $\mathrm{H}_{2}$, vol. \% & $<0.015$ & $<0.015$ & NA & 0.129 & $<0.015$ & $<0.015$ & $<0.015$ & $<0.015$ & 0.015 \\
\hline SRAT MS Peak, lb/hr DWPF & 0.0114 & $<0.0090$ & NA & $<0.0090$ & 0.131 & 0.0074 & $<0.0090$ & 0.0169 & 0.0092 \\
\hline SME MS Peak, lb/hr DWPF & 0.0669 & $<0.0038$ & NA & 0.0308 & NA & $<0.0038$ & $<0.0038$ & $<0.0038$ & $<0.0038$ \\
\hline
\end{tabular}

\section{Hydrogen Uncertainty Analysis}

A hydrogen uncertainty analysis was completed using the data from GN70, GN78 and 79. The purpose of the analysis is to place an upper bound (with 95\% confidence) on the reported maximum hydrogen concentrations and generation rates encountered during the nitric-glycolic acid flowsheet scaled demonstrations.

Several factors contribute to uncertainty in the hydrogen measurements and generation rates. The factors considered in this analysis include the following:

- Uncertainty in the air purge flowrate

- Uncertainty in the helium tracer flowrate

- Uncertainty in the hydrogen and helium concentrations in the GC calibration gasses

- Uncertainty due to variance in GC measurements

- Bias due to drift in the calibration during the run

The MKS flow meter / flow controllers used for the flow rates of the air purge and helium tracer had tolerances of $2 \%$ of full scale and were tracked in the M\&TE program. The standards used to calibrate GC for concentration of hydrogen, helium, and other gasses have a NIST certification to 5\% of the reported concentrations. The variance in the GC measurements is estimated from the data collected during the instrument calibration check. The bias due to the calibration drift is handled by processing the calibration of the GC in a manner to provide conservatively large hydrogen generation measurements. The pre- and post-run calibration-check information is compared, and the sets of calibration data are used that would maximize the instrument-measured hydrogen and nitrous oxide concentrations and minimize the helium tracer concentration.

Uncertainty can be applied to the maximum hydrogen concentration and the corresponding helium concentrations by Equations [8] and [9], respectively. The concentrations of hydrogen and helium $\left(\mathrm{C}_{\mathrm{H} 2}\right.$ and $\mathrm{C}_{\mathrm{He}}$ ) are in mole fraction. These equations are the $\mathrm{GC}$ responses (e.g., area $_{\mathrm{H} 2}$ and area $_{\mathrm{He}}$ ) multiplied by the 
GC response factor and the targeted to actual purge flow. The GC response is in terms of an area. Gas of known concentration (calibration gas) is run through the GC. A response factor of known concentration/known area is then used to determine concentration of gasses in the SRAT and SME offgas. A response factor is determined as the relationship between the integrated chromatogram area with the concentration in the gas standard. $\mathrm{F}_{\mathrm{SRNL} \text {-purge }}$ is the target SRNL purge rate; and $\mathrm{F}_{\text {air }}$ and $\mathrm{F}_{\mathrm{He}}$ are the flow rates of air and helium purges at lab scale. While the ratio $\left(\mathrm{F}_{\mathrm{SRNL}-\text { purge }} /\left(\mathrm{F}_{\mathrm{air}}+\mathrm{F}_{\mathrm{He}}\right)\right)$ is by definition equal to 1 (the sum of the He and air flow rates are set to equal the SRNL purge rate), these terms allow accounting for the uncertainty in the He and air flow controllers.

$$
\begin{gathered}
C_{\mathrm{H}_{2}}=\operatorname{area}_{\mathrm{H}_{2}}\left(\frac{C_{\mathrm{H}_{2}}^{\text {std }}}{\text { area }_{\mathrm{H}_{2}}^{\text {std }}}\right)\left(\frac{F_{\text {SRNL-purge }}}{F_{\text {air }}+F_{\mathrm{He}}}\right) \\
C_{\mathrm{He}}=\operatorname{area}_{\mathrm{He}}\left(\frac{C_{\mathrm{He}}^{\text {std }}}{\text { area }_{\mathrm{He}}^{\text {std }}}\right)\left(\frac{F_{\text {SRNL-purge }}}{F_{\text {air }}+F_{\mathrm{He}}}\right)
\end{gathered}
$$

The value calculated by Equation [10] is the DWPF-scale generation rate of hydrogen, in lb/hr, scaled from the results for mole fraction concentrations calculated by Equations [8] and [9]. The DWPF-scale purge flow rates ( $F_{\text {DWPF-purge }}$ ) are based on $93.7 \mathrm{scfm}$ purge in the SRAT and $74 \mathrm{scfm}$ purge in the SME. MW is the molecular weight of $\mathrm{H}_{2}$ and $\mathrm{A}_{\text {constant }}$ is a combination of multiple unit conversions. The helium tracer concentration is used to correct the offgas data for the unknown total offgas flowrate.

$$
\mathrm{H}_{\text {2(DWPF-scale) }}(\mathrm{lb} / \mathrm{hr})=\frac{C_{\mathrm{H}_{2}}}{C_{\mathrm{He}}} * F_{\mathrm{He}} * \frac{F_{\text {DWPF-purge }}}{F_{\text {SRNL-purge }}} * M W_{\mathrm{H}_{2}} * A_{\text {constant }}
$$

The inputs were processed using the statistical package GUM Workbench ${ }^{26}$ to propagate the uncertainty in the measurements to the calculated results. Table 3-25 and Table 3-26 contain the results of the uncertainty analysis for the DWPF-scale maximum concentrations and generation rates, respectively. The expanded uncertainties are the half-widths of the two sided 95\% confidence intervals on the average analytical measurements and adjusted to DWPF scale when necessary. The upper 95\% bounds are the sum of the averages and the half-widths of the confidence intervals. Thus, these upper 95\% bounds are the maximum values adjusted for the uncertainty based on the nitric-glycolic acid flowsheet scaled demonstration. 
Table 3-25. Maximum concentrations of hydrogen encountered in runs GN70, GN78 and GN79

\begin{tabular}{|c|c|c|c|}
\hline & $\begin{array}{c}\text { Maximum } \\
\text { Concentration (vol\%) }\end{array}$ & $\begin{array}{c}\text { Expanded } \\
\text { Uncertainty (vol\%) }\end{array}$ & $\begin{array}{c}\text { Maximum } \\
\text { Concentration Upper } \\
\text { 95\% Bound } \\
\text { (vol\%) }\end{array}$ \\
\hline GN70 SRAT H$_{2}$ & 0.0114 & 0.0079 & $\mathbf{0 . 0 1 9 3}$ \\
\hline GN70 SME $\mathbf{H}_{2}$ & 0.0069 & 0.0078 & $\mathbf{0 . 0 1 4 7}$ \\
\hline GN78 SME $\mathbf{H}_{2}$ & 0.0200 & 0.0071 & $\mathbf{0 . 0 2 7 1}$ \\
\hline GN79 SME $\mathbf{H}_{2}$ & 0.0306 & 0.0074 & $\mathbf{0 . 0 3 8 0}$ \\
\hline
\end{tabular}

Table 3-26. DWPF-scale generation rates of hydrogen from runs GN70, GN78 and GN79

\begin{tabular}{|c|c|c|c||}
\hline & $\begin{array}{c}\text { DWPF-scale Rate } \\
(\mathbf{l b} / \mathbf{h r})\end{array}$ & $\begin{array}{c}\text { Expanded Uncertainty } \\
(\mathbf{l b} / \mathbf{h r})\end{array}$ & $\begin{array}{c}\text { DWPF-scale Rate } \\
\text { Upper 95\% Bound } \\
(\mathbf{l b} / \mathbf{h r})\end{array}$ \\
\hline GN70 SRAT $\mathbf{H}_{\mathbf{2}}$ & 0.0042 & 0.0024 & $\mathbf{0 . 0 0 6 6}$ \\
\hline GN70 SME $\mathbf{H}_{2}$ & 0.0022 & 0.0020 & $\mathbf{0 . 0 0 4 4}$ \\
\hline GN78 SME $\mathbf{H}_{\mathbf{2}}$ & 0.0049 & 0.0014 & $\mathbf{0 . 0 0 6 3}$ \\
\hline GN79 SME $\mathbf{H}_{\mathbf{2}}$ & 0.0072 & 0.0015 & $\mathbf{0 . 0 0 8 7}$ \\
\hline
\end{tabular}

This uncertainty analysis is primarily based on the analytical method. There are some uncertainties that are not being addressed by this analysis. The CPC process simulation was performed on a sludge simulant based on Sludge Batch 8 composition and this uncertainty analysis does not take into account any potential differences between the material used in the simulation and the material that is actually processed in DWPF.

\subsection{Ammonia}

DWPF installed three ammonia scrubbers to remove ammonia from the offgas. Ammonia is a potentially flammable gas and can accumulate in the offgas piping as ammonium nitrate, an explosive. The ammonia scrubbers are designed to remove ammonia from the offgas and prevent ammonium nitrate deposits. If ammonia is produced in the SRAT or SME, it is typically retained as ammonium unless the $\mathrm{pH}$ increases above 7. Little offgas ammonia is expected in nitric-glycolic acid flowsheet runs due to the acidic $\mathrm{pH}$ throughout the SRAT and SME cycles. Analyses were performed to quantify the ammonia produced:

- Ammonium in the Ammonia Scrub solution

- Ammonium in the condensate streams (SRAT Dewater, Post SRAT FAVC, SME Decon Dewater, SME Frit Dewater, and Post SME FAVC)

- Ammonium in the SRAT and SME products

- Ammonia in the offgas

Scrubbing is a common name given the unit operation normally known as gas absorption. In this process, mass is transferred from the gas phase into the liquid phase for the purpose of removing material from the gas stream. Wet packed scrubbers can achieve extremely high contaminant removals. Scrubbing can achieve simultaneous removal of various contaminants as well as provide gas cooling and particle emission control. In DWPF, the ammonia scrubbers serve as a secondary condenser along with removing ammonia, nitric acid, antifoam degradation compounds, and mercury from the offgas stream. In the case of a foamover, the ammonia scrubbers can also serve as a filter for the insoluble solids. 


\subsubsection{Ammonia Generation}

No ammonia or ammonium is present in the sludge simulant. Any ammonia present in these tests was generated during processing. There are two potential sources of ammonia, step wise reduction of nitrate or nitrite and reaction of nitrogen with hydrogen (Haber-Bosch produces using high temperature, high pressure with catalyst to maximize reaction rate, 150-250 bar and between $400-500{ }^{\circ} \mathrm{C}$, much higher temperature and pressure than DWPF). The reduction of nitrogen via this reaction is below:

$$
\mathrm{N}_{2}+3 \mathrm{H}_{2} \rightarrow 2 \mathrm{NH}_{3}
$$

Ammonia can also be generated by the stepwise reduction of nitrite or nitrate to ammonia by formic or glycolic acid, catalyzed by noble metals. This is the likely chemical route to production of ammonia.

\subsubsection{Ammonia Scrubber Processing Summary}

The contents of the ammonia scrubber reservoir (nominally 750g of water for the 4- $\mathrm{L}$ and 22-L runs and 2,250 g for the 220-L runs plus added $\mathrm{HCl}$ to produce a $\mathrm{pH} 2$ scrub solution) were analyzed for the presence of ammonium at the end of the SRAT and SME cycle. The nitrate concentration in this solution was also measured. The ammonia scrubbers removed at least 500 times more nitrate than ammonium. The ammonium concentration of the SRAT and SME products were completed. In addition, the offgas was analyzed for ammonia by both the mass spec and FTIR but no ammonia was detected. The results are summarized in Table 3-27.

Table 3-27. Ammonia Scrubber Summary Table

\begin{tabular}{|c|c|c|c|c|c|c|c|c|}
\hline Acid Stoichiometry & \multicolumn{4}{|c|}{$100 \%$} & \multicolumn{4}{|c|}{$110 \%$} \\
\hline Run & GN70 & GN76 & GN74 & GN79 & GN73 & GN75 & GN77 & GN78 \\
\hline Acid Ratio, Glycolic:Total & 0.5831 & 0.5831 & 0.5454 & 0.5454 & 0.5221 & 0.5221 & 0.5221 & 0.5221 \\
\hline $\begin{array}{l}\text { Chloride in Scrubber before } \\
\text { run, } \mathrm{mg} / \mathrm{L}\end{array}$ & 620 & 620 & 620 & 620 & 620 & 620 & 620 & 620 \\
\hline Post SRAT Nitrate, mg/L & 18,400 & 97,300 & 18,000 & 182,000 & 18,600 & 12,700 & 62600 & 91,800 \\
\hline Post SME Nitrate, $\mathrm{mg} / \mathrm{L}$ & NM & NM & 19,500 & 185,000 & 12,900 & 11,500 & 62600 & 133,000 \\
\hline Post SRAT $\mathrm{NH}_{4}{ }^{+}, \mathrm{mg} / \mathrm{L}$ & 29 & $<25$ & NM & $<25$ & NM & NM & $<25$ & $<25$ \\
\hline Post SME $\mathrm{NH}_{4}^{+}, \mathrm{mg} / \mathrm{L}$ & $<25$ & $<25$ & $<25$ & $<25$ & $<25$ & $<25$ & $<25$ & 35 \\
\hline
\end{tabular}

The ammonia scrubbers were designed to limit the offgas ammonia concentration to be $<10 \mathrm{~g}$ ammonia/kg offgas. The ammonia generation is so low in nitric-glycolic acid flowsheet runs that processing without the ammonia scrubbers is acceptable.

\subsubsection{Ammonia Scrubber Scaling}

The DWPF ammonia scrubbers are designed ${ }^{27}$ to remove approximately $99.9 \%\left(<10 \mathrm{ppm}_{\mathrm{v}}\right)$ of the ammonia in the offgas using a $\mathrm{pH}$ 1-3 nitric acid solution. The SMECT contents (controlled at $\mathrm{pH}$ 1-3 using generated and added nitric acid) are used for scrubbing ammonia from the offgas. The volume of the SMECT varies from 3,000-8,000 gallons as the SMECT collects condensate from the SRAT and SME and the condensate is transferred to the RCT. The SMECT has an online $\mathrm{pH}$ meter and the $\mathrm{pH}$ is controlled by adding nitric acid. 
The ammonia scrubbers used in the scaled demos were not scaled from the DWPF scrubbers. Table 3-28 summarizes the differences in the scrubbers. To effectively scale a scrubber, the same height is required with a smaller cross sectional area. Hence a $1 / 8000^{\text {th }}$ scale scrubber (4-L) would need a 111 ” tall, 0.2 " diameter column with 1" Intalox ${ }^{\mathrm{TM}}$ saddles. Obviously this is not practical. So glass Raschig rings were used instead of stainless steel Intalox ${ }^{\mathrm{TM}}$ saddles and shorter/fatter columns were used to fit in the hoods. The ammonia scrubbing should be adequate at all scales to remove almost all of the ammonia. As a result, the only comparison was the amount of ammonia scrubbed.

Table 3-28. Ammonia Scrubber Scaling

\begin{tabular}{|c|c|c|c|c|c|}
\hline Parameter & DWPF SRAT $^{28}$ & DWPF SME ${ }^{28}$ & 220-L & 22-L & 4-L \\
\hline Height, inches & 111 & 60 & 21 & 6 & 6 \\
\hline Diameter, inches & 18.812 & 11.938 & 3.5 & 1 & 1 \\
\hline Liquid Flow & $20 \mathrm{gpm}$ & 10 gpm & 0.683 lpm & $0.080 \mathrm{lpm}$ & $0.080 \mathrm{lpm}$ \\
\hline Vapor Flow & $1645 \mathrm{lb} / \mathrm{hr}$ & $404 \mathrm{lb} / \mathrm{hr}$ & $13.2-15.5 \mathrm{~L} / \mathrm{min}$ & $1.83-2.02 \mathrm{~L} / \mathrm{min}$ & $0.35 \mathrm{~L} / \mathrm{min}$ \\
\hline Ammonia & $1.2 \mathrm{lb} / \mathrm{hr}$ & $2.5 \mathrm{lb} / \mathrm{hr}$ & NA & NA & NA \\
\hline Scrub Volume & \multicolumn{2}{|c|}{$3,000-8.000$ gallons } & $750 \mathrm{~mL}$ & $750 \mathrm{~mL}$ & $2,250 \mathrm{~mL}$ \\
\hline Packing & \multicolumn{2}{|c|}{ 1” stainless steel Intalox ${ }^{\mathrm{TM}}$ saddles } & \multicolumn{3}{|c|}{$\begin{array}{c}\text { 6mm x 6mm x 1mm (L x O.D. x thickness) borosilicate } \\
\text { glass Raschig rings }\end{array}$} \\
\hline
\end{tabular}

Two additional difference in this testing compared to DWPF are that the ammonia scrubber solution was segregated from the other dewater condensate and hydrochloric acid was used instead of nitric acid to control the scrub solution $\mathrm{pH}$. In DWPF, the condensate from the SRAT, SME and FAVC all collect in the SMECT. As a result, the SMECT contents are always a combination of all three condensates along with anything scrubbed in one of the scrubbers. Isolation of each of the dewater samples allows a simpler comparison of the condensate composition. In the scaled experiments, a $\mathrm{pH} 2 \mathrm{HCl}$ solution (nitrate free) was used to prepare the scrub ammonia and improve the determination of the nitrate balance. The SRAT and SME dewater condensate and FAVC condensate were all collected separately. The use of $\mathrm{HCl}$ in the scrub solution is not recommended for future studies as the chloride may react with mercury to form calomel.

\subsubsection{Ammonia Scrubber Deposits}

Evidence of solids (primarily mercury) carrying through the offgas and into the ammonia scrubber was observed. The offgas line from the SRAT condenser to the ammonia scrubber had visible black deposits, seen in Figure 3-23 and Figure 3-24. Solids were collected in the packing of the ammonia scrubber used for the GN78-110 experiments. The packing material was soaked in an 8 molar nitric acid. Analysis of the acid for mercury indicated only $2.4 \mathrm{~g}$ of mercury collected in the scrubber packing $(0.5 \%$ of total mercury added). If these solids were calomel, it is likely the result of the $\mathrm{HCl}$ used in the scrub solution or the excessive chloride introduced with the ruthenium chloride. The switch of acids may have created an issue that DWPF will not see. 


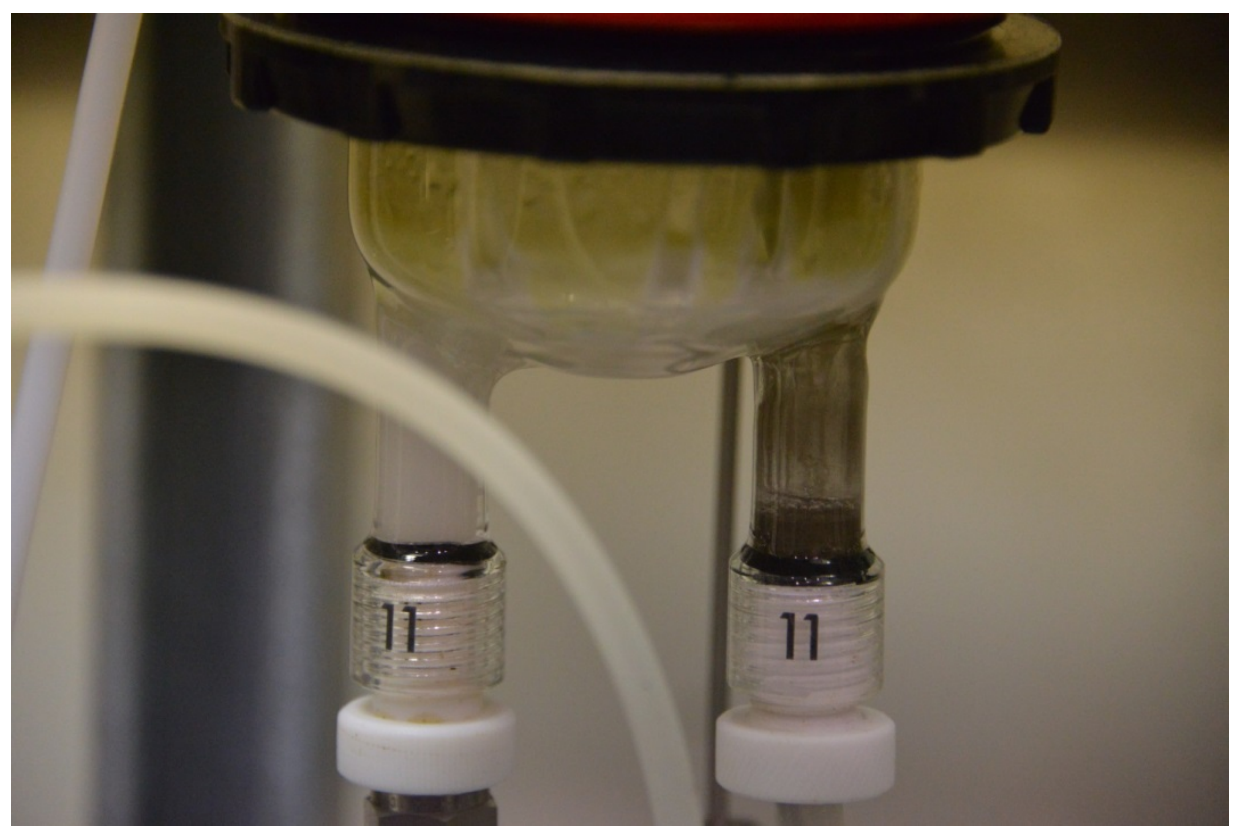

Figure 3-23: GN78-110 Ammonia scrubber

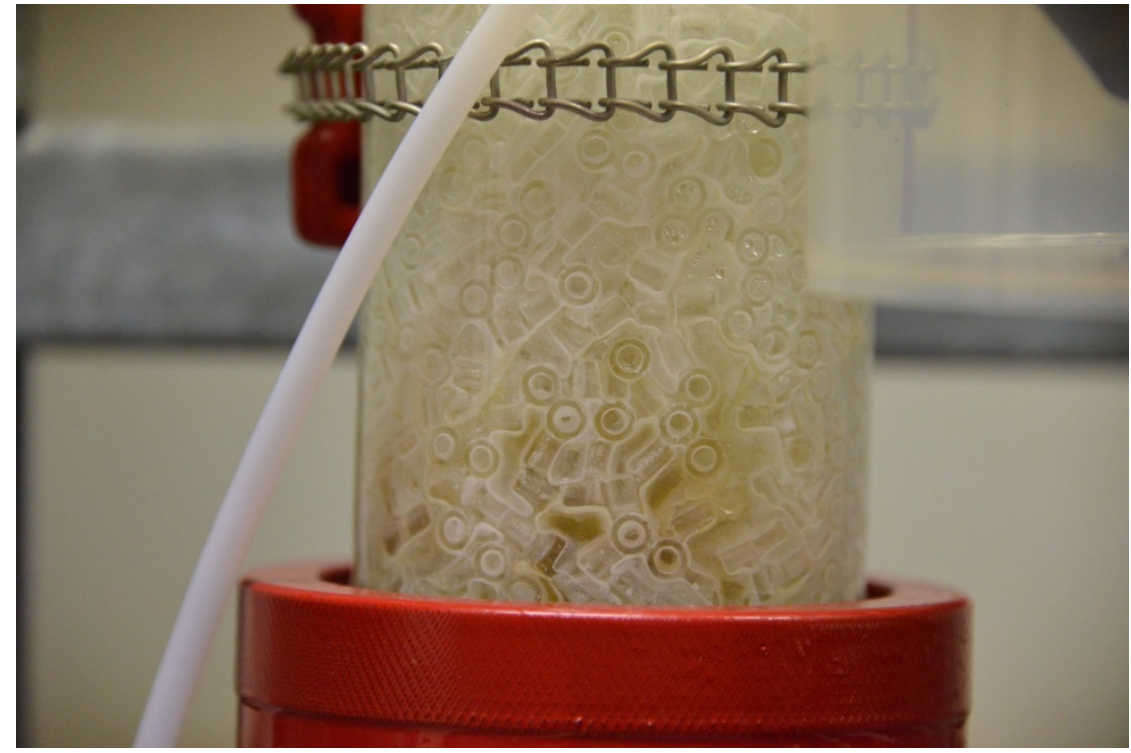

Figure 3-24: GN78-110 Ammonia scrubber packing

\subsubsection{Ammonia Scrubber Ammonia Scrubbing}

Very little ammonium was detected in the SRAT product or SME product and no ammonia was detected in the offgas. In addition, no ammonium was detected in the SRAT dewater, SME decon dewater, SME frit dewater, or FAVC liquid samples. The scrubber solution is the most likely stream that could be high in ammonium but little ammonium was detected. The results are summarized in Table 3-29. 
Table 3-29. FAVC Ammonium Analyses, $\mu \mathrm{g} / \mathrm{mL}$

\begin{tabular}{|c|c|c|c|}
\hline Run & $\begin{array}{c}\text { Acid } \\
\text { Stoichiometry }\end{array}$ & $\begin{array}{l}\text { Post SRAT } \\
\text { FAVC }\end{array}$ & $\begin{array}{l}\text { Post SME } \\
\text { FAVC }\end{array}$ \\
\hline GN70 & \multirow{4}{*}{$100 \%$} & $<10$ & $<10$ \\
\hline GN76 & & \multicolumn{2}{|c|}{ Not Measured } \\
\hline GN74 & & $<10$ & $<10$ \\
\hline GN79 & & $<5$ & $<5$ \\
\hline GN73 & \multirow{4}{*}{$110 \%$} & $<10$ & $<10$ \\
\hline GN75 & & $<10$ & $<10$ \\
\hline GN77 & & \multicolumn{2}{|c|}{ Not Measured } \\
\hline GN78 & & Not Measured & $<5$ \\
\hline GN71 & $125 \%$ & $<10$ & $<10$ \\
\hline
\end{tabular}

Based on this testing, the generation of ammonia is virtually absent in the nitric-glycolic acid flowsheet. Any ammonia generated would remain chemically bound in the SRAT and SME solutions due to the ammonia equilibrium of the acidic solutions. As a result, the ammonia scrubbers are not necessary for removing ammonia in this flowsheet. This should eliminate the need to maintain the $\mathrm{pH}$ of the SMECT at $\mathrm{pH} 1-3$.

No direct measurement of the SRAT/SME vapor space was completed. In recent antifoam degradation testing, the SRAT/SME offgas was routed through heated sample lines directly to the FTIR. This allowed the measurement of antifoam degradation species in the offgas. In future testing, the heated sample line could be used to measure the offgas directly exiting the SRAT/SME prior to the condensers and ammonia scrubber. This would further validate the low ammonia generation for this flowsheet.

Although the ammonia scrubbers may not be necessary for ammonia removal, operation of the scrubbers many still be beneficial to processing. The scrubbers are effective at removing any particulate or salt that is present in the offgas, including nitric acid and mercury. The scrubbers also serve as secondary condensers since the SRAT and SME condensers are both undersized. These functions should be reconsidered for this flowsheet.

Ammonia scrub solution samples were pulled throughout the runs. The ammonia scrubber mass changed very little during the SRAT and SME processing. Any mass change was due to the scrubbing of nitric acid, ammonium nitrate, water, evaporation or sampling. Note that the experiment scale increased by about 50x going from 4-L to 220-L scale but the scrub solution volume only increased by $3 x$. As a result, the concentrations of anions and cations increase in scale due to lower dilution.

\subsubsection{Ammonia Scrubber Acid Scrubbing}

The ammonia scrubbers were effective in scrubbing nitric acid from the offgas. The scrub solution nitrate concentration is summarized in Table 3-27.

The ammonia scrub solution was sampled every 6 hours. In hindsight, it would have been better to have pulled frequent samples during the latter part of glycolic acid addition and early in boiling, when the offgas $\mathrm{NO}_{2}$ concentration is highest. The nitrate concentration is fairly constant once the peak is reached (usually the sample pulled 3 hours into SRAT dewater. Note the ammonia scrubber volume was not scaled so all 
three scales had a different nitrate concentration. Two y-axis scales were used to permit an easier comparison of the runs. There were two sets of data for each 220-L scale runs. Figure 3-25 is a graph of scrub solution nitrate concentration throughout the SRAT cycles.

It is interesting to note the highest acid stoichiometry runs had the lowest amount of scrubbed nitric acid. This is likely due to the fact that the nitrite is destroyed much earlier in the high acid stoichiometry experiments, prior to boiling. Since the SRAT is not boiling when much of the $\mathrm{NO}_{\mathrm{x}}$ is being generated, there is less water vapor to scrub the $\mathrm{NO}_{2}$ from the offgas in the SRAT and may lead to better scrubbing of nitric acid in the SRAT condenser, leading to less nitric acid scrubbed by the ammonia scrubber. The scrub solution nitrate in the one $125 \%$ acid stoichiometry run was less than half the nitrate in the $100 \%$ acid stoichiometry experiments. In all cases at the same scale, the $110 \%$ acid stoichiometry runs were lower in nitrate than the $100 \%$ acid stoichiometry runs.

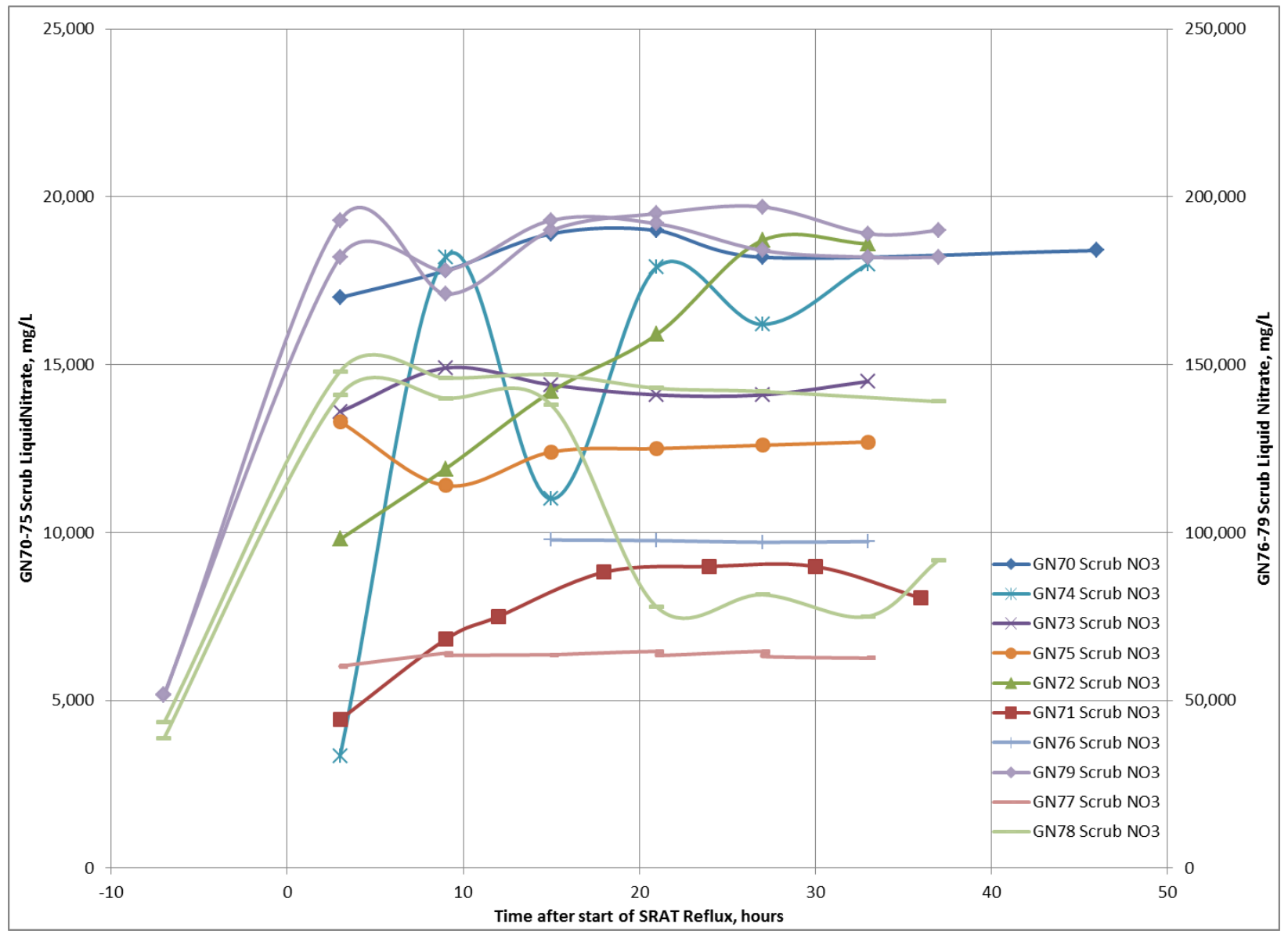

Figure 3-25. Ammonia Scrub Solution Nitrate Concentration during SRAT Cycle

In the 220-L experiments, the ammonia scrub solution had significant formate present during the SRAT cycle. No oxalate or glycolate was detected in the scrub solution in any of the runs. What is interesting about the formate is that its concentration peaked at 20 or 30 hours after the start of reflux and decreased below detection limits by the completion of the SRAT cycle. It is likely that the formic acid reduced mercury to elemental, explaining the decrease in $\mathrm{Hg}$ concentration in the scrub solution during SRAT dewater. The data is summarized in Figure 3-26. 


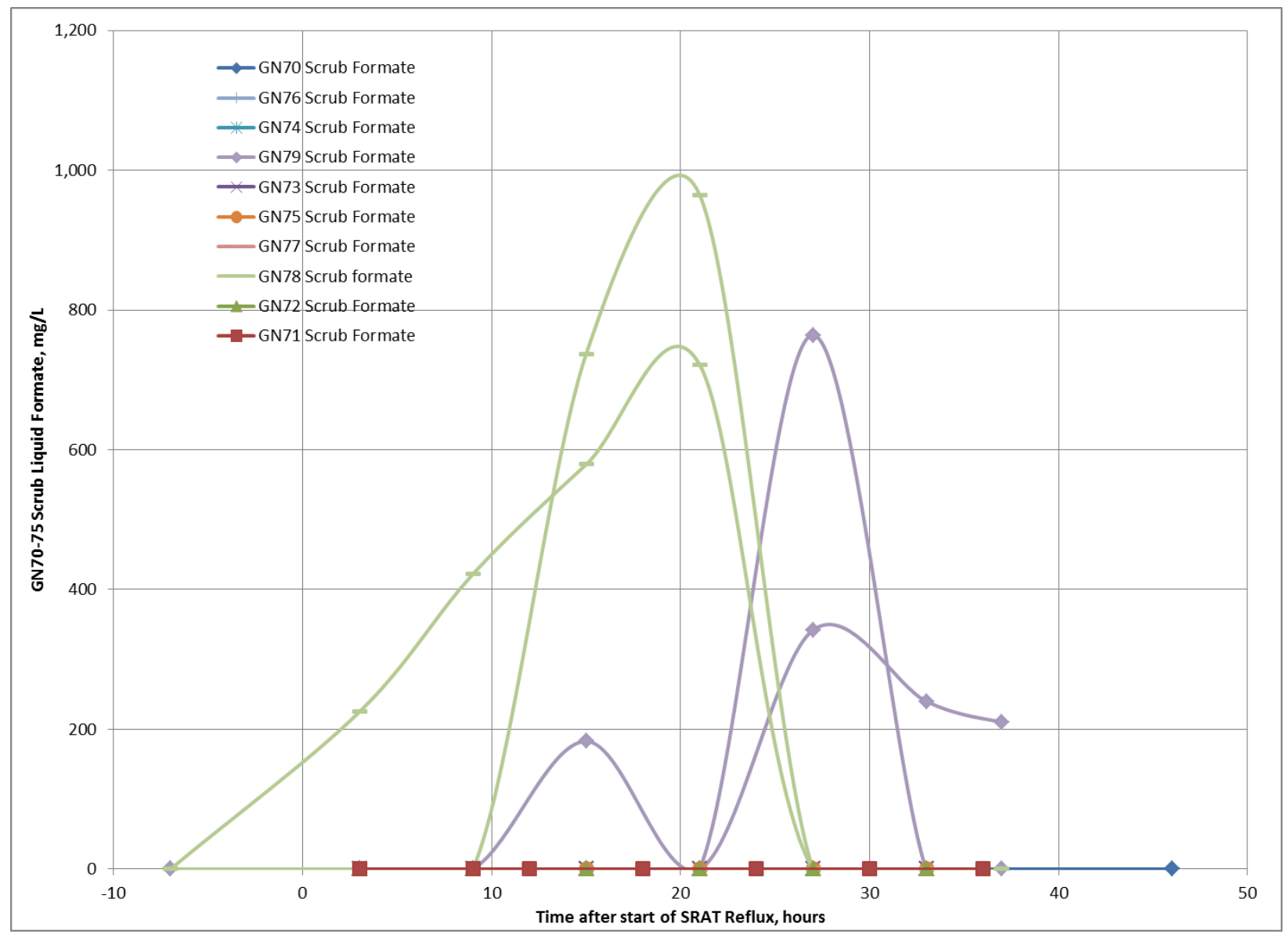

Figure 3-26. Ammonia Scrub Solution Formate Concentration during SRAT Cycle

\subsubsection{Ammonia Scrubber Mercury Scrubbing}

The ammonia scrubber solution can remove mercury from the offgas. In the majority of the runs, the scrubber solution was not analyzed until three hours after dewater is complete (about 7 hours after acid addition is complete). Only for runs GN78 and GN79 were samples pulled at the completion of acid addition. Note that in all runs but GN77, the sample pulled 3 hours into dewater had the highest concentration of $\mathrm{Hg}$. It appears that mercury was scrubbed from the offgas until about three hours into dewater and then the mercury concentration continually dropped throughout the SRAT and SME cycle.

One possible explanation for this would be the formation of calomel $\left(\mathrm{Hg}_{2} \mathrm{Cl}_{2}\right)$ due to the $\mathrm{HCl}$ added to scrub solution before experiment or the $\mathrm{RuCl}_{3}$ added to the sludge as the source of $\mathrm{Ru}$. These two modifications added at least 20x the chloride that is expected in the sludge. Note that white solids were found in the ammonia scrubber (calomel is a white solid). It is recommended that nitric acid is used for the $\mathrm{pH}$ adjustment in the scrub solution and Ruthenium Nitroso Hydroxide (a chloride free form of ruthenium) in a nitric acid solution is used for the $\mathrm{Ru}$ addition to eliminate the overaddition of chloride during simulant SRAT and SME demonstrations. A graph showing the scrubber solution mercury concentration throughout the SRAT and SME cycles is shown in Figure 3-27. 


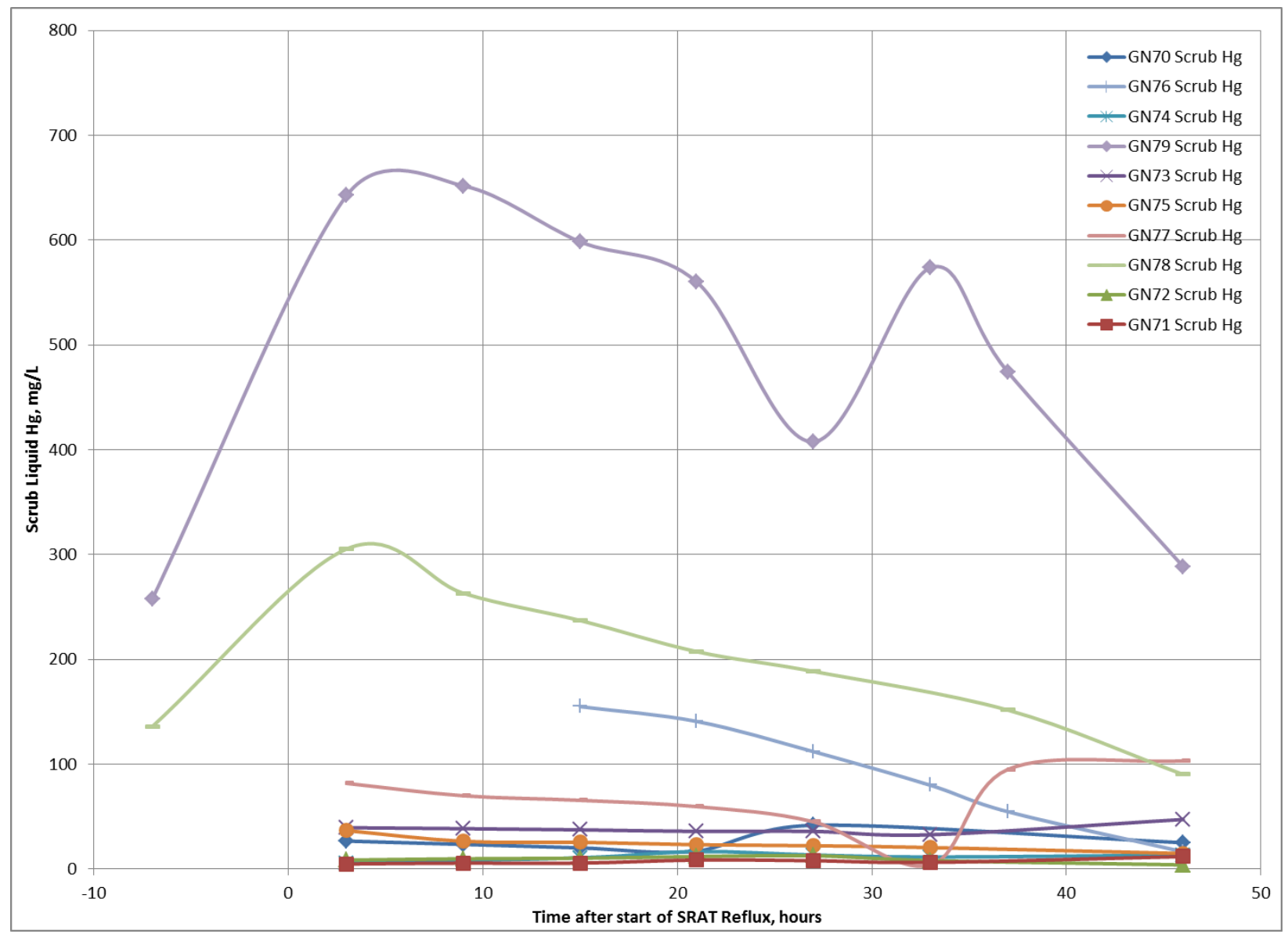

Figure 3-27. Ammonia Scrub Solution Mercury Concentration, mg/L

A mass balance on the mercury was completed for each run. In all cases the mercury recovered in the scrub solution was a small fraction of the initial sludge mercury. The data is summarized in Table 3-30.

Table 3-30. Hg Mass Balance for Ammonia Scrub Solution

\begin{tabular}{||l|c|c|c|c|c|c|c|c|c||}
\hline Acid Stoichiometry & \multicolumn{4}{|c|}{$100 \%$} & \multicolumn{4}{c||}{$110 \%$} \\
\hline Run & GN70 & GN76 & GN74 & GN79 & GN73 & GN75 & GN77 & GN78 \\
\hline $\begin{array}{l}\text { Acid Ratio, } \\
\text { Glycolic:Total }\end{array}$ & 0.5831 & 0.5831 & 0.5454 & 0.5454 & 0.5221 & 0.5221 & 0.5221 & 0.5221 \\
\hline Hg Concentration, mg/L & 41.9 & 155.1 & 16.8 & 651.8 & 47.4 & 36.8 & 103.3 & 305.5 \\
\hline Scrub Solution Vol, mL & 750 & 750 & 750 & 2250 & 750 & 750 & 750 & 2250 \\
\hline Mercury Mass, g & 0.031 & 0.116 & 0.013 & 1.47 & 0.036 & 0.028 & 0.077 & 0.687 \\
\hline DWPF Scale, g & 246 & 157 & 99 & 259 & 279 & 216 & 116 & 143 \\
\hline \hline
\end{tabular}

The scrubbers did aid in the dissolution of mercury. Mercury is scrubbed by the ammonia scrubber. It is likely collected as a very fine elemental mercury droplet, which can be redissolved by the nitric acid in the scrub solution. The scrub solution mercury concentration is summarized in Table 3-31. 
Table 3-31. Post SRAT and SME Ammonia Scrub Solution Mercury Concentration

\begin{tabular}{|l|c|c|c||}
\hline \multirow{2}{*}{ Run } & \multirow{2}{*}{$\begin{array}{c}\text { Acid } \\
\text { Stoichiometry }\end{array}$} & $\begin{array}{c}\text { Post SRAT Scrub } \\
\text { Solution Hg, } \\
\mathrm{mg} / \mathrm{L}\end{array}$ & $\begin{array}{c}\text { Post SME Scrub } \\
\text { Solution Hg, } \\
\mathrm{mg} / \mathrm{L}\end{array}$ \\
\hline GN70 & \multirow{3}{*}{$100 \%$} & $41.9^{*}$ & 25.2 \\
\hline GN76 & & 54.7 & 16.6 \\
\cline { 1 - 2 } GN74 & & $11.6^{*}$ & 13.4 \\
\hline GN79 & & 474 & 289 \\
\hline GN73 & \multirow{2}{*}{$110 \%$} & $32.8^{*}$ & 47.4 \\
\hline GN75 & & $20.6^{*}$ & 14.9 \\
\hline GN77 & & 95.3 & 103 \\
\hline GN78 & & 152 & 90.3 \\
\hline GN71 & $125 \%$ & $6.46^{*}$ & 12.0 \\
\cline { 3 - 4 } & & & \\
\cline { 3 - 4 } & & &
\end{tabular}

* Samples pulled very late in SRAT cycle, about 4 hours before the SRAT was complete

\subsubsection{Ammonia Scrubber Silicon Scrubbing}

The post SRAT and SME scrubber samples were analyzed by ICP for cations (Table 3-32) and (Table 3-33). The samples were high only in silicon. Deionized water is used in preparation of the scrub solution, so the likely source for the high $\mathrm{Si}$ concentration is antifoam degradations products (Trimethylsilanol or TMS has been identified in other similar testing). In this testing the source of the Si was not positively identified. There might have been more entrainment in the larger scale runs, although it was very small.

Table 3-32. Post SRAT Ammonia Scrub Solution Cation Analyses, mg/L

\begin{tabular}{|l|c|c|c|c|c|c|c|c|c|}
\hline \hline Acid Stoichiometry & \multicolumn{4}{|c|}{ 100\% } & \multicolumn{4}{c|}{ 110\% } \\
\hline Run & GN70* & GN76 & GN74* & GN79 & GN73* & GN75* & GN77 & GN78 \\
\hline Acid Ratio, Glycolic:Total & 0.5831 & 0.5831 & 0.5454 & 0.5454 & 0.5221 & 0.5221 & 0.5221 & 0.5221 \\
\hline \hline $\mathrm{Al}$ & 0.140 & 0.112 & $<0.100$ & 0.238 & 0.106 & $<0.100$ & 0.175 & 1.90 \\
\hline $\mathrm{Ba}$ & 0.157 & $<0.010$ & $<0.010$ & $<0.010$ & 3.86 & $<0.010$ & $<0.010$ & $<0.010$ \\
\hline $\mathrm{Ca}$ & 0.668 & 0.555 & 0.452 & 0.873 & 0.665 & 0.436 & 0.896 & 1.43 \\
\hline $\mathrm{Fe}$ & 1.42 & 1.213 & 2.22 & 4.22 & 0.311 & 0.198 & 0.898 & 1.54 \\
\hline $\mathrm{Mn}$ & $<0.100$ & $<0.100$ & $<0.100$ & 0.249 & $<0.100$ & $<0.100$ & $<0.100$ & 0.181 \\
\hline $\mathrm{Na}$ & 1.81 & 2.44 & 2.14 & 2.89 & 1.56 & 1.61 & 2.70 & 1.84 \\
\hline $\mathrm{Ni}$ & $<0.100$ & $<0.100$ & $<0.100$ & 0.861 & $<0.100$ & $<0.100$ & $<0.100$ & 0.108 \\
\hline $\mathrm{P}$ & $<0.100$ & $<0.100$ & $<0.100$ & 0.239 & $<0.100$ & $<0.100$ & $<0.100$ & 0.251 \\
\hline $\mathrm{Si}$ & 28.5 & 185 & 51.0 & 349 & 89.4 & 171 & 231 & 281 \\
\hline $\mathrm{Sn}$ & $<1.00$ & $<0.100$ & $<1.00$ & 0.578 & $<1.00$ & $<1.00$ & $<0.100$ & 0.212 \\
\hline $\mathrm{C}$ & & &
\end{tabular}

Note: $\mathrm{Cr}, \mathrm{Cu}, \mathrm{K}, \mathrm{Li}, \mathrm{Mg}, \mathrm{S}, \mathrm{Zn}$, and Zr had concentrations below the detection limit of 0.1 or $1.0 \mathrm{mg} / \mathrm{L}$ 
Table 3-33. Post SME Ammonia Scrub Solution Cation Analyses, mg/L

\begin{tabular}{|l|c|c|c|c|c|c|c|c||}
\hline Acid Stoichiometry & \multicolumn{4}{|c|}{$\mathbf{1 0 0 \%}$} & \multicolumn{4}{c||}{$\mathbf{1 1 0 \%}$} \\
\hline Run & GN70 & GN76 & GN74 & GN79 & GN73 & GN75 & GN77 & GN78 \\
\hline Acid Ratio, Glycolic:Total & 0.5831 & 0.5831 & 0.5454 & 0.5454 & 0.5221 & 0.5221 & 0.5221 & 0.5221 \\
\hline $\mathrm{Al}$ & 0.148 & 0.132 & 0.164 & 0.322 & 0.170 & 0.155 & 0.242 & 2.50 \\
\hline $\mathrm{Ba}$ & 0.170 & 0.024 & $<0.010$ & $<0.010$ & 3.88 & $<0.010$ & $<0.010$ & $<0.010$ \\
\hline $\mathrm{Ca}$ & 0.178 & 0.774 & 0.366 & 0.930 & 0.569 & 0.344 & 1.15 & 1.76 \\
\hline $\mathrm{Cr}$ & 0.062 & 0.197 & 1.31 & 63.5 & 0.179 & 0.208 & 0.088 & 1.72 \\
\hline $\mathrm{Fe}$ & 1.51 & 1.62 & 4.45 & 238 & 0.684 & 0.633 & 1.28 & 6.23 \\
\hline $\mathrm{Mn}$ & $<0.100$ & $<0.100$ & $<0.100$ & 8.24 & $<0.100$ & $<0.100$ & $<0.100$ & 0.384 \\
\hline $\mathrm{Na}$ & 1.76 & 2.96 & 2.82 & 2.89 & 1.61 & 1.37 & 3.10 & 2.08 \\
\hline $\mathrm{Ni}$ & $<0.100$ & $<0.100$ & 0.732 & 32.7 & $<0.100$ & $<0.100$ & $<0.100$ & 1.23 \\
\hline $\mathrm{P}$ & $<0.100$ & $<0.100$ & 0.250 & 0.366 & 0.312 & 0.290 & $<0.100$ & 0.236 \\
\hline $\mathrm{Si}$ & 38.5 & 111 & 88.1 & 134 & 69.9 & 189 & 116 & 151 \\
\hline $\mathrm{Sn}$ & $<1.00$ & $<1.00$ & 0.671 & 30.8 & $<0.200$ & $<0.200$ & $<1.00$ & 0.833 \\
\hline $\mathrm{Hg}$ & 25.2 & 16.6 & 13.4 & 289 & 47.4 & 14.9 & 103 & 90.3 \\
\hline \hline
\end{tabular}

Note: $\mathrm{Cu}, \mathrm{K}, \mathrm{Li}, \mathrm{Mg}, \mathrm{S}, \mathrm{Zn}$, and Zr had concentrations below the detection limit of 0.1 or $1.0 \mathrm{mg} / \mathrm{L}$

The silicon concentration had a sinusoidal shape, with a peak about every twelve hours. The Si concentration peaked upon the addition of diluted antifoam (contained antifoam degradation products). These volatile species slowly evaporate so the concentration decreases until the next antifoam addition. The data is summarized in Figure 3-28. It should be noted during the boiling portion of the SRAT, the antifoam was added every twelve hours. The antifoam for each test was prepared as a 1:10 solution on the first day of testing and the same diluted antifoam solution was used throughout the testing. In subsequent antifoam degradation testing ${ }^{23}$, diluted antifoam degraded quickly to form TMS. When the dilute antifoam was added, the TMS flashed off and was collected in the condensate and scrub solution. 


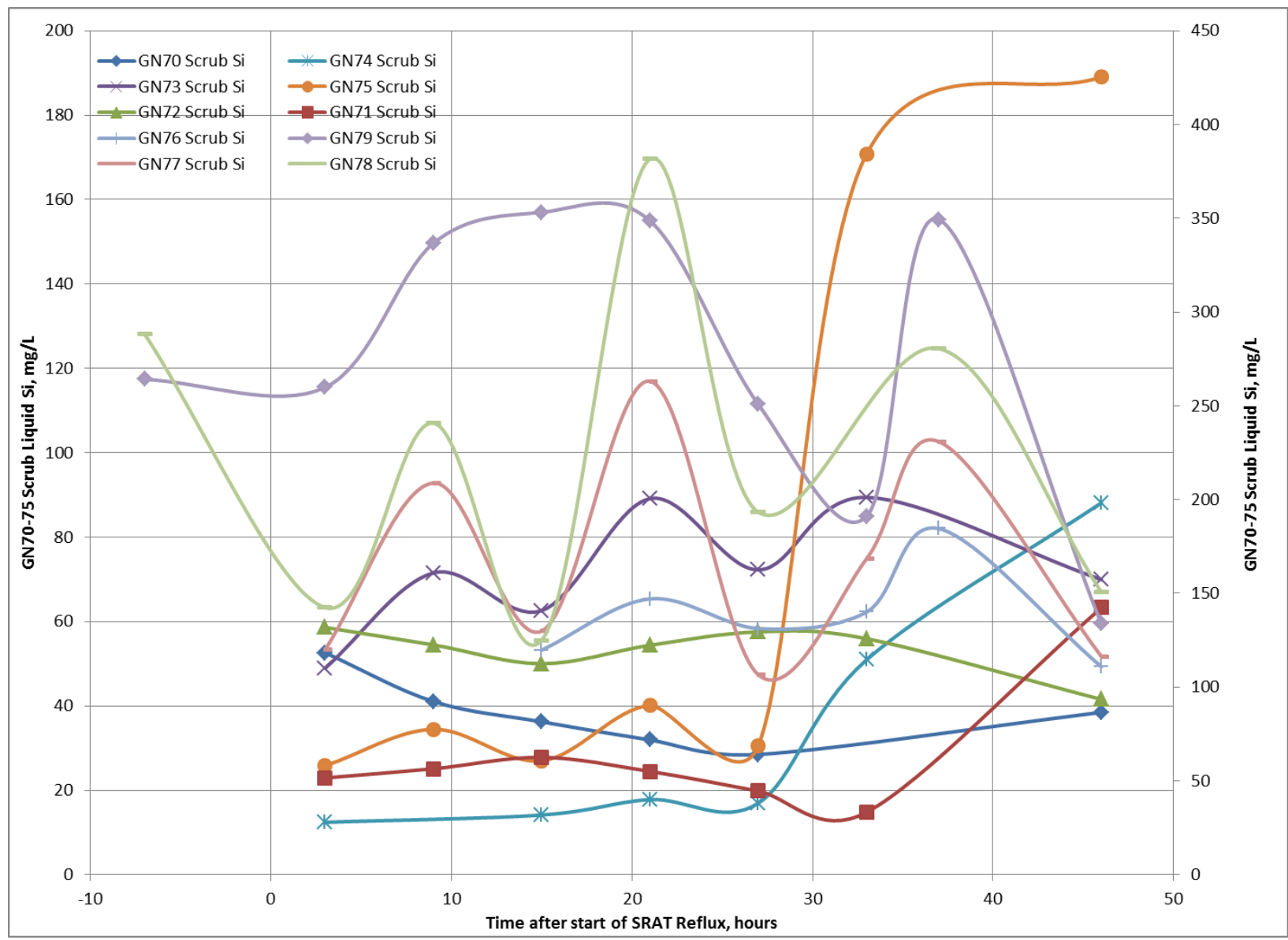

Figure 3-28. Ammonia Scrub Solution Silicon Concentration during SRAT Cycles

Note also that in run GN 75, there was a significant increase in Si concentration between the 27 hour post dewater sample (6/16/15 5:09 pm) and the 33 hour post dewater sample (6/16/15 11:05 pm). There was no increase in any other anion or cation. No explanation is given to explain this Si increase.

\subsection{Condensate Generated During SRAT and SME Cycles}

In DWPF, CPC condensate is collected in the SMECT, which is also used as the scrub solution for the ammonia scrubbers. In order to better understand the composition of the various condensate streams that are collected in the SMECT, each of these streams was collected separately in these experiments and the condensate collected was not used for the ammonia scrubber solution. Note that no ARP or MCU addition was completed so no condensate was produced to simulate these operations. The primary condensate sources in these experiments were the SRAT dewater, the SRAT FAVC condensate, the SME decon dewater, the SME frit dewater, and the SME FAVC condensate. In addition, the ammonia scrub solution (initially a $\mathrm{pH} 2$ solution prepared by adding hydrochloric acid to water) was sampled and analyzed. Each of these is discussed in the sections below.

\subsubsection{SRAT Dewater}

The SRAT offgas is cooled in the SRAT condenser, and the condensate is collected in the MWWT. The SRAT condenser used a cooling water temperature of $25^{\circ} \mathrm{C}$. The temperature profile of the SRAT condenser is summarized in Figure 3-29. Note that the condensers are oversized as there is only a small 
cooling water temperature increase in both the SRAT condenser and FAVC. This is different from the DWPF where the SRAT cooling water return temperature is typically $>40^{\circ} \mathrm{C}$ during SRAT and SME boiling operations.

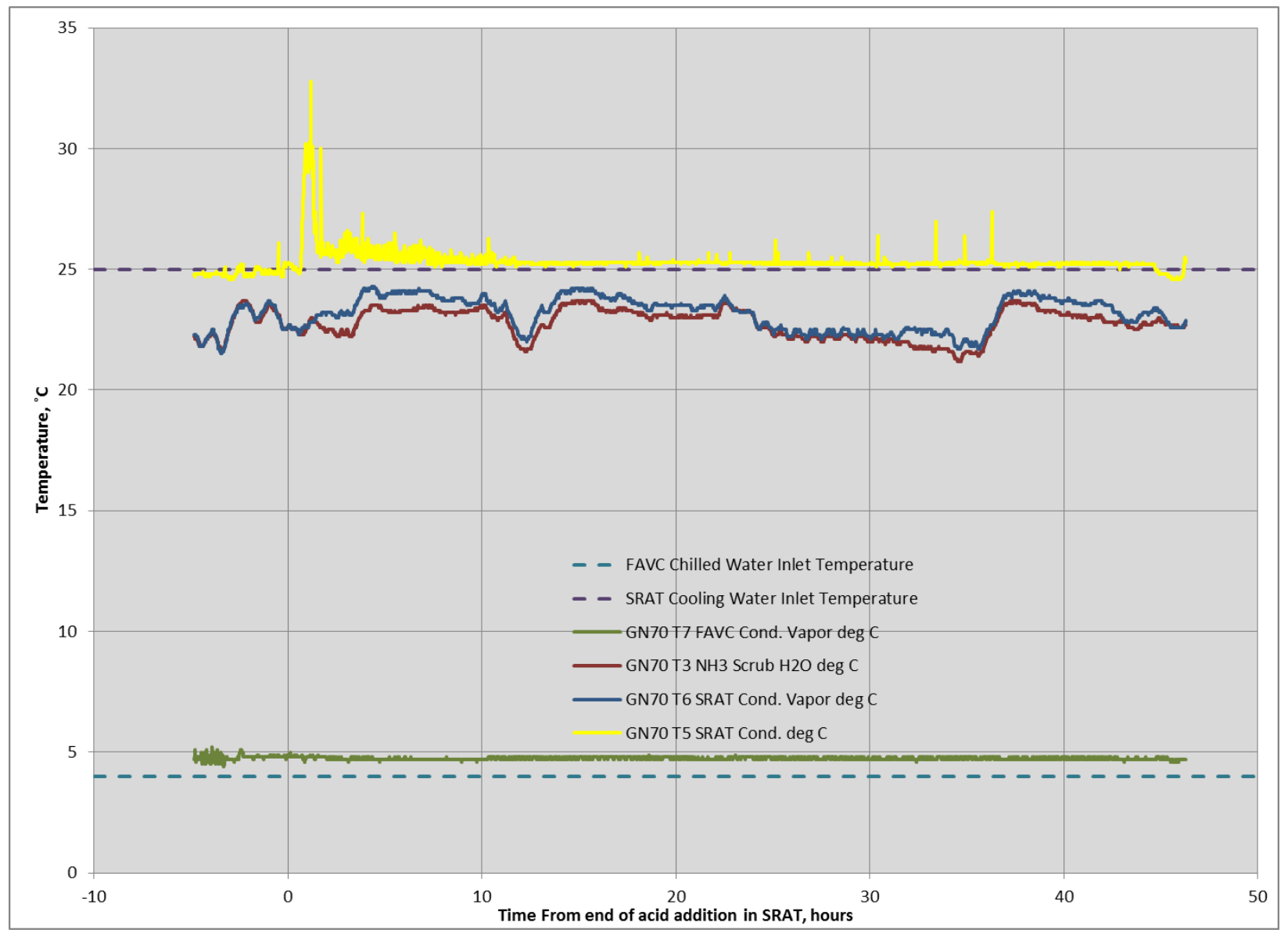

Figure 3-29. GN70 Cooling Water, Condensate, and Offgas Temperature Profile

The condensate collected after acid addition (SRAT dewater) had a $\mathrm{pH}$ of 1.2-1.5 and had the highest concentration of dissolved mercury of any of the dewater samples. The condensate samples were analyzed by IC for anions (Table 3-34) and ICP for cations (Table 3-35) and had a significant concentration of only mercury, silicon, nitrate, formate and glycolate. The SRAT dewater is high in nitric acid and is a good solution for keeping the SMECT condensate between 1 and 3. It is also a good solution for dissolving elemental mercury from the condenser, ammonia scrubber and SMECT. 
Table 3-34. Post SRAT Dewater Anion Analyses, mg/L, Density, g/mL, pH

\begin{tabular}{|c|c|c|c|c|c|c|c|c|}
\hline \multirow{2}{*}{$\begin{array}{l}\text { Acid Stoichiometry } \\
\text { Run }\end{array}$} & \multicolumn{4}{|c|}{$100 \%$} & \multicolumn{4}{|c|}{$110 \%$} \\
\hline & GN70 & GN76 & GN74 & GN79 & GN73 & GN75 & GN77 & GN78 \\
\hline Acid Ratio, Glycolic:Total & 0.5831 & 0.5831 & 0.5454 & 0.5454 & 0.5221 & 0.5221 & 0.5221 & 0.5221 \\
\hline $\mathrm{C}_{2} \mathrm{H}_{3} \mathrm{O}_{3}$ & 45.3 & 83.2 & 16.8 & 35.8 & 31.9 & 37.1 & 34.9 & 54.5 \\
\hline $\mathrm{HCO}_{2}$ & 128 & 127 & 46.1 & 109 & 150 & 135 & 91.5 & 148 \\
\hline $\mathrm{F}$ & $<100$ & $<100$ & $<100$ & $<100$ & $<100$ & $<100$ & $<100$ & $<100$ \\
\hline $\mathrm{Cl}$ & $<100$ & $<100$ & $<100$ & $<100$ & $<100$ & $<100$ & $<100$ & $<100$ \\
\hline $\mathrm{NO}_{2}$ & $<100$ & $<100$ & $<100$ & $<100$ & $<100$ & $<100$ & $<100$ & $<100$ \\
\hline $\mathrm{SO}_{4}$ & $<100$ & $<100$ & $<100$ & $<100$ & $<100$ & $<100$ & $<100$ & $<100$ \\
\hline $\mathrm{C}_{2} \mathrm{O}_{4}$ & $<100$ & $<100$ & $<100$ & $<100$ & $<100$ & $<100$ & $<100$ & $<100$ \\
\hline $\mathrm{NO}_{3}$ & 10,000 & 8,680 & 9,150 & 5,210 & 6,010 & 4,880 & 8,020 & 8,800 \\
\hline Density & 1.0040 & 1.0030 & 1.0035 & 1.0000 & 0.9884 & 1.0009 & 1.0027 & 1.0030 \\
\hline $\mathrm{pH}$ & 1.24 & 1.31 & 1.26 & 1.49 & 1.43 & 1.54 & 1.31 & 1.29 \\
\hline
\end{tabular}

Table 3-35. Post SRAT Dewater Cation Analyses, mg/L

\begin{tabular}{||l|c|c|c|c|c|c|c|c|c||}
\hline Acid Stoichiometry & \multicolumn{4}{|c|}{$100 \%$} & \multicolumn{4}{c|}{$10 \%$} \\
\hline Run & GN70 & GN76 & GN74 & GN79 & & GN73 & GN75 & GN77 & GN78 \\
\hline Acid Ratio, Glycolic:Total & 0.5831 & 0.5831 & 0.5454 & 0.5454 & 0.5221 & 0.5221 & 0.5221 & 0.5221 \\
\hline $\mathrm{Al}$ & 0.23 & 1.867 & 0.128 & 0.102 & $<0.100$ & $<0.100$ & $<0.100$ & $<0.100$ \\
\hline $\mathrm{Ca}$ & 1.50 & 2.867 & 1.066 & 0.933 & 0.700 & 0.670 & 0.648 & 0.817 \\
\hline $\mathrm{Cu}$ & $<0.100$ & 0.107 & $<0.100$ & $<0.100$ & $<0.100$ & $<0.100$ & $<0.100$ & $<0.100$ \\
\hline $\mathrm{Fe}$ & $<0.100$ & 13.681 & $<0.100$ & $<0.100$ & $<0.100$ & $<0.100$ & $<0.100$ & 0.240 \\
\hline $\mathrm{Mn}$ & 3.69 & 12.345 & $<0.100$ & $<0.100$ & $<0.100$ & $<0.100$ & $<0.100$ & 0.121 \\
\hline $\mathrm{Na}$ & 11.68 & 29.27 & 1.48 & 1.18 & 1.02 & 1.17 & 0.69 & 3.49 \\
\hline $\mathrm{Ni}$ & $<0.100$ & 1.952 & $<0.100$ & 0.274 & $<0.100$ & $<0.100$ & $<0.100$ & 1.319 \\
\hline $\mathrm{S}$ & $<0.100$ & 0.701 & $<0.100$ & $<0.100$ & $<0.100$ & $<0.100$ & $<0.100$ & $<0.100$ \\
\hline $\mathrm{Si}$ & 39.1 & 79.0 & 1.37 & 98 & 6.53 & 3.07 & 53.3 & 191 \\
\hline $\mathrm{Hg}$ & 218 & 223 & 382 & 187 & 80.2 & 154 & 278 & 294 \\
\hline
\end{tabular}

Note: Ba, Cr, K, Li, Mg, P, Sn, Ti, Zn, and Zr had concentrations below the detection limit of 0.1 or 1.0 $\mathrm{mg} / \mathrm{L}$

The source of the silica in the SRAT dewater is not known. Previous reports have assumed it is an antifoam degradation product. The Si concentration in the dewater samples is much higher than the measured HMDSO or TMS that have been detected in condensate samples $(<2 \mathrm{mg} / \mathrm{L})$. The silica is higher in the larger vessels (1-39 mg/L in 4-L runs, 53-79 in 22-L runs, and 98-191 mg/L in 220-L runs). And there is very little sodium in the condensate so it is unlikely that the glassware is the source, although the silicon concentration in the $2^{\text {nd }}$ run in each of the larger rigs was lower in silicon than the first run.

It is interesting to note that the formate concentration was always higher than the glycolate concentration in condensate samples due to formic acid's much higher volatility than glycolic acid. Unless a carryover event occurs (Run GN76), the SRAT dewater is very low in most metals. 


\subsubsection{SRAT FAVC}

The condensate collected from the FAVC at the completion of the SRAT cycle is a very small mass relative to the dewater samples. The condensate samples were analyzed by IC for anions (Table 3-38) and ICP for cations (Table 3-39). The samples were very high in nitrate and had a significant concentration of silicon. Runs GN78 and GN79 had higher concentrations of $\mathrm{Ca}, \mathrm{Cr}, \mathrm{Fe}$, and $\mathrm{Ni}$, as would be expected if a small amount of slurry is present in the FAVC sample.

Table 3-36. Post SRAT FAVC Anion Analyses, mg/L

\begin{tabular}{|c|c|c|c|c|c|c|c|c|}
\hline Acid Stoichiometry & \multicolumn{4}{|c|}{$100 \%$} & \multicolumn{4}{|c|}{$110 \%$} \\
\hline Run & GN70 & GN76 & GN74 & GN79 & GN73 & GN75 & GN77 & GN78 \\
\hline Acid Ratio, Glycolic:Total & 0.5831 & 0.5831 & 0.5454 & 0.5454 & 0.5221 & 0.5221 & 0.5221 & 0.5221 \\
\hline $\mathrm{C}_{2} \mathrm{H}_{3} \mathrm{O}_{3}$ & \multirow{7}{*}{ 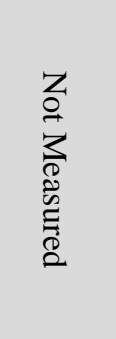 } & $<100$ & $<100$ & $<100$ & $<100$ & $<100$ & $<100$ & \multirow{7}{*}{ 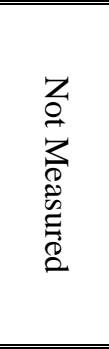 } \\
\hline $\mathrm{HCO}_{2}$ & & 102 & $<100$ & $<100$ & $<100$ & $<100$ & 116 & \\
\hline $\mathrm{Cl}$ & & $<100$ & $<100$ & $<100$ & $<100$ & $<100$ & $<100$ & \\
\hline $\mathrm{NO}_{2}$ & & $<100$ & $<100$ & 159 & $<100$ & $<100$ & $<100$ & \\
\hline $\mathrm{SO}_{4}$ & & $<100$ & $<100$ & $<100$ & $<100$ & $<100$ & $<100$ & \\
\hline $\mathrm{C}_{2} \mathrm{O}_{4}$ & & $<100$ & $<100$ & $<100$ & $<100$ & $<100$ & $<100$ & \\
\hline $\mathrm{NO}_{3}$ & & 104,000 & 193,000 & 49,700 & 146,000 & 145,000 & 90,700 & \\
\hline
\end{tabular}

Table 3-37. Post SRAT FAVC Cation Analyses, mg/L

\begin{tabular}{|c|c|c|c|c|c|c|c|c|}
\hline Acid Stoichiometry & \multicolumn{4}{|c|}{$100 \%$} & \multicolumn{4}{|c|}{$110 \%$} \\
\hline Run & GN70 & GN76 & GN74 & GN79 & GN73 & GN75 & GN77 & GN78 \\
\hline Acid Ratio, Glycolic:Total & 0.5831 & 0.5831 & 0.5454 & 0.5454 & 0.5221 & 0.5221 & 0.5221 & 0.5221 \\
\hline$\overline{\mathrm{Al}}$ & \multirow{12}{*}{ 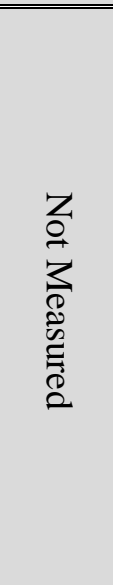 } & 0.038 & 1.50 & 0.192 & 0.612 & 0.286 & 0.027 & \multirow{12}{*}{ 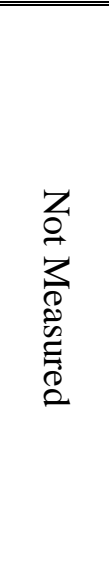 } \\
\hline $\mathrm{Ba}$ & & $<0.010$ & $<0.010$ & 0.025 & $<0.010$ & $<0.010$ & $<0.010$ & \\
\hline $\mathrm{Ca}$ & & 0.287 & 0.189 & 1.21 & 0.203 & 0.138 & 0.147 & \\
\hline $\mathrm{Cr}$ & & $<0.100$ & $<0.100$ & 9.11 & 0.417 & $<0.100$ & $<0.100$ & \\
\hline $\mathrm{Fe}$ & & $<0.100$ & 0.551 & 65.2 & 3.77 & 0.459 & $<0.100$ & \\
\hline $\mathrm{Mn}$ & & $<0.100$ & $<0.100$ & 0.206 & $<0.100$ & $<0.100$ & $<0.100$ & \\
\hline $\mathrm{Na}$ & & $<10.0$ & $<10.0$ & 44.8 & $<10.0$ & $<10.0$ & $<10.0$ & \\
\hline $\mathrm{Ni}$ & & $<0.100$ & $<0.100$ & 143 & 0.220 & $<0.100$ & $<0.100$ & \\
\hline $\mathrm{P}$ & & 0.282 & 0.300 & 0.271 & 0.275 & 0.318 & 0.250 & \\
\hline $\mathrm{Si}$ & & 352 & 146 & 181 & 19.0 & 287 & 320 & \\
\hline Sn & & $<0.200$ & $<0.200$ & 3.92 & 0.291 & $<0.200$ & $<0.200$ & \\
\hline $\mathrm{Zn}$ & & $<0.100$ & $<0.100$ & 0.140 & $<0.100$ & $<0.100$ & $<0.100$ & \\
\hline
\end{tabular}

Note: $\mathrm{Cu}, \mathrm{K}, \mathrm{Li}, \mathrm{Mg}, \mathrm{S}$, and Zr had concentrations below the detection limit of 0.1 or $1.0 \mathrm{mg} / \mathrm{L}$

\subsubsection{SME Decon Dewater}

The condensate collected during the SME decon dewater had a $\mathrm{pH}$ of 4-8 and had a low concentration of dissolved mercury compared to SRAT dewater samples. The condensate samples were analyzed by IC for anions (Table 3-38) and ICP for cations (Table 3-39) and had a significant concentration of only mercury and silicon. No anions were detected in the condensate samples. No carryover event occurred in the SME decon dewater phase during the testing. 
Table 3-38. Post SME Decon Dewater Anion Analyses, mg/L, Density, g/mL, pH

\begin{tabular}{||c|c|c|c|c|c|c|c|c|c|}
\hline Acid Stoichiometry & \multicolumn{4}{|c|}{$\mathbf{1 0 0} \%$} & \multicolumn{5}{c|}{$\mathbf{1 1 0} \%$} \\
\hline Run & GN70 & GN76 & GN74 & GN79 & & GN73 & GN75 & GN77 & GN78 \\
\hline Acid Ratio, Glycolic:Total & 0.5831 & 0.5831 & 0.5454 & 0.5454 & 0.5221 & 0.5221 & 0.5221 & 0.5221 \\
\hline \hline $\mathrm{C}_{2} \mathrm{H}_{3} \mathrm{O}_{3}$ & $<100$ & $<100$ & $<100$ & $<100$ & $<100$ & $<100$ & $<100$ & $<100$ \\
\hline $\mathrm{HCO}_{2}$ & $<100$ & $<100$ & $<100$ & $<100$ & $<100$ & $<100$ & $<100$ & $<100$ \\
\hline $\mathrm{F}$ & $<100$ & $<100$ & $<100$ & $<100$ & $<100$ & $<100$ & $<100$ & $<100$ \\
\hline $\mathrm{Cl}$ & $<100$ & $<100$ & $<100$ & $<100$ & $<100$ & $<100$ & $<100$ & $<100$ \\
\hline $\mathrm{NO}_{2}$ & $<100$ & $<100$ & $<100$ & $<100$ & $<100$ & $<100$ & $<100$ & $<100$ \\
\hline $\mathrm{SO}_{4}$ & $<100$ & $<100$ & $<100$ & $<100$ & $<100$ & $<100$ & $<100$ & $<100$ \\
\hline $\mathrm{C}_{2} \mathrm{O}_{4}$ & $<100$ & $<100$ & $<100$ & $<100$ & $<100$ & $<100$ & $<100$ & $<100$ \\
\hline $\mathrm{NO}_{3}$ & $<100$ & $<100$ & $<100$ & $<100$ & $<100$ & $<100$ & $<100$ & $<100$ \\
\hline $\mathrm{Density}$ & 0.9982 & 0.9982 & 0.9979 & 0.9979 & 0.9982 & 0.9982 & 0.9980 & 0.9980 \\
\hline $\mathrm{pH}$ & 7.49 & 7.14 & 7.36 & 7.51 & 4.66 & 4.60 & 4.18 & 4.18 \\
\hline
\end{tabular}

Table 3-39. Post SME Decon Dewater Cation Analyses, mg/L

\begin{tabular}{||l|c|c|c|c|c|c|c|c|c||}
\hline \hline Acid Stoichiometry & \multicolumn{4}{|c|}{$\mathbf{1 0 0 \%}$} & \multicolumn{4}{c|}{$\mathbf{1 1 0 \%}$} \\
\hline Run & GN70 & GN76 & GN74 & GN79 & & GN73 & GN75 & GN77 & GN78 \\
\hline Acid Ratio, Glycolic:Total & 0.5831 & 0.5831 & 0.5454 & 0.5454 & & 0.5221 & 0.5221 & 0.5221 & 0.5221 \\
\hline \hline $\mathrm{Ca}$ & 0.825 & 0.652 & 0.736 & 0.633 & & 0.766 & 0.906 & 0.645 & 0.687 \\
\hline $\mathrm{Mn}$ & $<0.100$ & $<0.100$ & $<0.100$ & $<0.100$ & 0.577 & $<0.100$ & $<0.100$ & $<0.100$ \\
\hline $\mathrm{Na}$ & 4.46 & 1.51 & 2.34 & 1.76 & 2.94 & 1.57 & 1.16 & 1.17 \\
\hline $\mathrm{Si}$ & 33.3 & 76.3 & 118 & 231 & 24.1 & 124 & 4.76 & 175 \\
\hline $\mathrm{Hg}$ & 3.04 & 1.49 & 1.45 & $<1.00$ & 7.55 & 42.2 & 4.10 & $<1.00$ \\
\hline
\end{tabular}

Note: $\mathrm{Al}, \mathrm{Ba}, \mathrm{Cr}, \mathrm{Cu}, \mathrm{Fe}, \mathrm{K}, \mathrm{Li}, \mathrm{Mg}, \mathrm{Ni}, \mathrm{P}, \mathrm{S}, \mathrm{Sn}, \mathrm{Ti}, \mathrm{Zn}$, and $\mathrm{Zr}$ had concentrations below the detection limit of 0.1 or $1.0 \mathrm{mg} / \mathrm{L}$

\subsubsection{SME Frit Dewater}

The condensate collected during the SME frit dewater had a $\mathrm{pH}$ of 4-8 and had a low concentration of dissolved mercury compared to SRAT dewater samples. The condensate samples were analyzed by IC for anions (Table 3-40) and ICP for cations (Table 3-41) and had a significant concentration of only mercury and silicon. No anions were detected in the condensate samples. No carryover event occurred in the SME decon dewater phase during the testing. 
Table 3-40. Post SME Frit Dewater Anion Analyses, mg/L, Density, g/mL, pH

\begin{tabular}{||c|c|c|c|c|c|c|c|c|c|}
\hline \hline Acid Stoichiometry & \multicolumn{4}{|c|}{$100 \%$} & \multicolumn{5}{c|}{$\mathbf{1 1 0 \%}$} \\
\hline Run & GN70 & GN76 & GN74 & GN79 & GN73 & GN75 & GN77 & GN78 \\
\hline Acid Ratio, Glycolic:Total & 0.5831 & 0.5831 & 0.5454 & 0.5454 & 0.5221 & 0.5221 & 0.5221 & 0.5221 \\
\hline \hline $\mathrm{C}_{2} \mathrm{H}_{3} \mathrm{O}_{3}$ & $<100$ & $<100$ & $<100$ & $<100$ & $<100$ & $<100$ & $<100$ & $<100$ \\
\hline $\mathrm{HCO}_{2}$ & $<100$ & $<100$ & $<100$ & $<100$ & $<100$ & $<100$ & $<100$ & $<100$ \\
\hline $\mathrm{F}$ & $<100$ & $<100$ & $<100$ & $<100$ & $<100$ & $<100$ & $<100$ & $<100$ \\
\hline $\mathrm{Cl}$ & $<100$ & $<100$ & $<100$ & $<100$ & $<100$ & $<100$ & $<100$ & $<100$ \\
\hline $\mathrm{NO}_{2}$ & $<100$ & $<100$ & $<100$ & $<100$ & $<100$ & $<100$ & $<100$ & $<100$ \\
\hline $\mathrm{SO}_{4}$ & $<100$ & $<100$ & $<100$ & $<100$ & $<100$ & $<100$ & $<100$ & $<100$ \\
\hline $\mathrm{C}_{2} \mathrm{O}_{4}$ & $<100$ & $<100$ & $<100$ & $<100$ & $<100$ & $<100$ & $<100$ & $<100$ \\
\hline $\mathrm{NO}_{3}$ & $<100$ & $<100$ & $<100$ & $<100$ & $<100$ & $<100$ & $<100$ & $<100$ \\
\hline $\mathrm{Density}$ & 0.9982 & 0.9981 & 0.9927 & 0.9982 & 0.9979 & 0.9913 & 0.9916 & 0.9982 \\
\hline $\mathrm{pH}$ & 8.23 & 7.36 & 7.66 & 9.00 & 4.31 & 4.81 & 4.52 & 6.25 \\
\hline
\end{tabular}

Table 3-41. SME Post Frit Dewater Cation Analyses, mg/L

\begin{tabular}{|l|c|c|c|c|c|c|c|c|c|}
\hline \hline Acid Stoichiometry & \multicolumn{4}{|c|}{$\mathbf{1 0 0} \%$} & \multicolumn{4}{c|}{$\mathbf{1 1 0 \%}$} \\
\hline Run & GN70 & GN76 & GN74 & GN79 & & GN73 & GN75 & GN77 & GN78 \\
\hline Acid Ratio, Glycolic:Total & 0.5831 & 0.5831 & 0.5454 & 0.5454 & & 0.5221 & 0.5221 & 0.5221 & 0.5221 \\
\hline $\mathrm{Ca}$ & 0.680 & 0.643 & 0.664 & 0.632 & & 0.786 & 0.669 & 0.682 & 0.690 \\
\hline $\mathrm{Mn}$ & $<0.100$ & $<0.100$ & $<0.100$ & $<0.100$ & 1.016 & $<0.100$ & 0.097 & $<0.100$ \\
\hline $\mathrm{Na}$ & 0.89 & 1.25 & 0.92 & 0.69 & & 2.81 & 1.52 & 1.70 & 1.38 \\
\hline $\mathrm{Si}$ & 4.61 & 63.7 & 41.0 & 159 & & 24.3 & 10.8 & 96.3 & 212 \\
\hline $\mathrm{Hg}$ & 2.09 & $<1.00$ & $<1.00$ & $<1.00$ & & 14.0 & 2.49 & 1.24 & $<1.00$ \\
\hline
\end{tabular}

Note: $\mathrm{Al}, \mathrm{Ba}, \mathrm{Cr}, \mathrm{Cu}, \mathrm{Fe}, \mathrm{K}, \mathrm{Li}, \mathrm{Mg}, \mathrm{Ni}, \mathrm{P}, \mathrm{S}, \mathrm{Sn}, \mathrm{Ti}, \mathrm{Zn}$, and $\mathrm{Zr}$ had concentrations below the detection limit of 0.1 or $1.0 \mathrm{mg} / \mathrm{L}$

\subsubsection{SME FAVC}

The condensate collected from the FAVC at the completion of the SME cycle is a very small mass relative to the dewater samples. The samples were high in nitrate (but lower than post SRAT FAVC samples) and had low detected concentration of formate only in runs GN78 and GN79. The condensate samples were analyzed by IC for anions (Table 3-42) and ICP for cations (Table 3-43) and had a significant concentration of only silicon. Runs GN78 and GN79 had higher concentrations of $\mathrm{Ca}, \mathrm{Cr}, \mathrm{Fe}$, and Ni, as expected if there a small amount of slurry was present in the FAVC sample. 
Table 3-42. Post SME FAVC Anion Analyses, mg/L

\begin{tabular}{|c|c|c|c|c|c|c|c|c|}
\hline \multirow{2}{*}{$\begin{array}{l}\text { Acid Stoichiometry } \\
\text { Run }\end{array}$} & \multicolumn{4}{|c|}{$100 \%$} & \multicolumn{4}{|c|}{$110 \%$} \\
\hline & GN70 & GN76 & GN74 & GN79 & GN73 & GN75 & GN77 & GN78 \\
\hline Acid Ratio, Glycolic:Total & 0.5831 & 0.5831 & 0.5454 & 0.5454 & 0.5221 & 0.5221 & 0.5221 & 0.5221 \\
\hline $\mathrm{C}_{2} \mathrm{H}_{3} \mathrm{O}_{3}$ & \multirow{7}{*}{$\begin{array}{l}z \\
0 \\
0 \\
z \\
0 \\
0 \\
0 \\
0 \\
0 \\
0\end{array}$} & $<100$ & $<100$ & $<100$ & $<100$ & $<100$ & $<100$ & $<100$ \\
\hline $\mathrm{HCO}_{2}$ & & $<100$ & $<100$ & 258 & $<100$ & $<100$ & $<100$ & 352 \\
\hline $\mathrm{Cl}$ & & $<100$ & $<100$ & $<100$ & $<100$ & $<100$ & $<100$ & $<100$ \\
\hline $\mathrm{NO}_{2}$ & & $<100$ & $<100$ & $<100$ & $<100$ & $<100$ & $<100$ & $<100$ \\
\hline $\mathrm{SO}_{4}$ & & $<100$ & $<100$ & $<100$ & $<100$ & $<100$ & $<100$ & $<100$ \\
\hline $\mathrm{C}_{2} \mathrm{O}_{4}$ & & $<100$ & $<100$ & $<100$ & $<100$ & $<100$ & $<100$ & $<100$ \\
\hline $\mathrm{NO}_{3}$ & & 2,440 & 22,800 & 39,800 & 17,400 & 13,400 & 2,400 & 263,000 \\
\hline
\end{tabular}

Table 3-43. Post SME FAVC Cation Analyses, mg/L

\begin{tabular}{|c|c|c|c|c|c|c|c|c|}
\hline Acid Stoichiometry & \multicolumn{4}{|c|}{$100 \%$} & \multicolumn{4}{|c|}{$110 \%$} \\
\hline Run & GN70 & GN76 & GN74 & GN79 & GN73 & GN75 & GN77 & GN78 \\
\hline Acid Ratio, Glycolic:Total & 0.5831 & 0.5831 & 0.5454 & 0.5454 & 0.5221 & 0.5221 & 0.5221 & 0.5221 \\
\hline$\overline{\mathrm{Al}}$ & \multirow{11}{*}{ 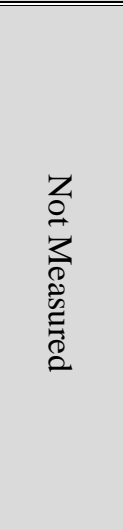 } & 0.017 & 0.536 & 0.161 & 0.195 & 0.052 & 0.012 & 0.390 \\
\hline $\mathrm{Ba}$ & & $<0.010$ & $<0.010$ & 0.029 & $<0.010$ & $<0.010$ & $<0.010$ & 0.023 \\
\hline $\mathrm{Ca}$ & & 0.141 & 0.145 & 1.008 & 0.124 & 0.128 & 0.164 & 1.52 \\
\hline $\mathrm{Cr}$ & & $<0.100$ & $<0.100$ & 7.38 & $<0.100$ & $<0.100$ & $<0.100$ & 10.4 \\
\hline $\mathrm{Fe}$ & & $<0.100$ & 0.263 & 66.2 & 0.341 & 0.254 & $<0.100$ & 87.5 \\
\hline $\mathrm{Mn}$ & & $<0.100$ & $<0.100$ & $<0.100$ & $<0.100$ & $<0.100$ & $<0.100$ & 2.14 \\
\hline $\mathrm{Na}$ & & $<10.0$ & $<10.0$ & 22.3 & $<10.0$ & $<10.0$ & $<10.0$ & 42.3 \\
\hline $\mathrm{Ni}$ & & $<0.100$ & $<0.100$ & 135 & $<0.100$ & $<0.100$ & $<0.100$ & 190 \\
\hline $\bar{P}$ & & 0.210 & 0.287 & 0.318 & 0.304 & 0.283 & 0.230 & 0.429 \\
\hline $\mathrm{Si}$ & & 297 & 140 & 94.8 & 91.1 & 258 & 500 & 325 \\
\hline Sn & & $<0.200$ & $<0.200$ & 3.21 & $<0.200$ & $<0.200$ & $<0.200$ & 4.40 \\
\hline
\end{tabular}

Note: $\mathrm{Cu}, \mathrm{K}, \mathrm{Li}, \mathrm{Mg}, \mathrm{S}, \mathrm{Zn}$, and Zr had concentrations below the detection limit of 0.1 or $1.0 \mathrm{mg} / \mathrm{L}$

\subsubsection{Composite SMECT Condensate}

The condensates produced during the testing were sampled and analyzed separately. The mass and concentration of each sample stream was combined in a mass balance to predict the composition of the condensate that would have been collected in the SMECT. The predicted composition for each run is summarized in Table 3-44. The calculated condensate is very low in nearly every element analyzed. Unless there was a foamover, only nitrate, silicon and mercury were detected at concentrations above the ICP detection limits. In particular, the condensate produced in the SME cycle was especially pure. Note that chloride was not reported as most of the chloride in the condensate was due to the addition of $\mathrm{HCl}$ to produce a $\mathrm{pH} 2$ starting scrub solution. 
Table 3-44. Calculated Composition of SRAT and SME Cycle SMECT Condensate, mg/L

\begin{tabular}{|c|c|c|c|c|c|c|c|c|}
\hline \multirow{2}{*}{$\begin{array}{l}\text { Acid } \\
\text { Stoichiometry } \\
\text { Run }\end{array}$} & \multicolumn{4}{|c|}{$100 \%$} & \multicolumn{4}{|c|}{$110 \%$} \\
\hline & GN70 & GN76 & GN74 & GN79 & GN73 & GN75 & GN77 & GN78 \\
\hline Volume, L & 6.35 & 25.3 & 5.73 & 213 & 5.77 & 5.76 & 23.9 & 171 \\
\hline $\mathrm{Al}$ & 0.056 & 0.478 & 0.092 & 0.034 & 0.100 & 0.036 & 0.008 & 0.039 \\
\hline $\mathrm{Ba}$ & 0.020 & 0.001 & BDL & BDL & 0.505 & BDL & BDL & 0.002 \\
\hline $\mathrm{Ca}$ & 0.812 & 1.19 & 0.714 & 0.697 & 0.742 & 0.678 & 0.639 & 0.721 \\
\hline $\mathrm{Cr}$ & 0.007 & 0.007 & 0.175 & 0.732 & 0.024 & 0.027 & 0.003 & 0.040 \\
\hline $\mathrm{Cu}$ & BDL & 0.026 & BDL & 0.013 & BDL & BDL & BDL & BDL \\
\hline $\mathrm{Fe}$ & 0.177 & 3.57 & 0.581 & 2.94 & 0.151 & 0.084 & 0.040 & 0.281 \\
\hline $\mathrm{Hg}$ & 43.6 & 56.9 & 86.9 & 46.5 & 56.0 & 89.9 & 68.0 & 68.5 \\
\hline $\mathrm{Mn}$ & 0.625 & 3.071 & 0.023 & 0.098 & 0.529 & 0.000 & 0.017 & 0.060 \\
\hline $\mathrm{Na}$ & 4.41 & 8.44 & 2.03 & 1.55 & 2.57 & 1.45 & 1.16 & 1.91 \\
\hline $\mathrm{Ni}$ & 0.000 & 0.496 & 0.147 & 1.081 & 0.024 & BDL & $\mathrm{BDL}$ & 0.624 \\
\hline $\mathrm{P}$ & BDL & 0.009 & 0.064 & 0.008 & 0.069 & 0.079 & 0.001 & 0.010 \\
\hline$S$ & BDL & 0.157 & BDL & BDL & BDL & BDL & BDL & BDL \\
\hline $\mathrm{Si}$ & 27.5 & 80.6 & 83.4 & 181 & 27.1 & 80.3 & 40.3 & 199 \\
\hline Sn & BDL & BDL & 0.087 & 0.353 & 0.001 & BDL & BDL & 0.018 \\
\hline $\mathrm{Zn}$ & BDL & BDL & BDL & 0.001 & BDL & BDL & 0.035 & 0.001 \\
\hline Nitrate & 3,850 & 5,280 & 4,680 & 3,470 & 3,370 & 3,020 & 4,120 & 4,240 \\
\hline Formate & 21.7 & 31.3 & 8.7 & 27.3 & 27.3 & 24.3 & 21.2 & 34.2 \\
\hline
\end{tabular}

Note: K, Li, Mg, Ti, Zr, fluoride, nitrite, phosphate, sulfate, oxalate, and glycolate were less than detectable in the condensate. Chloride was not calculated as $\mathrm{HCl}$ was used in the scrub solution and $\mathrm{RuCl} 3$ was added to the sludge so $>90 \%$ of the $\mathrm{Cl}$ came from these nonprototypic additions.

Note 2: Many of the analyses for all samples were below detection limit (BDL)

\subsection{Physical Properties}

The physical properties of rheology and heat transfer will be discussed in this section. Note that the simulant used in this testing is designed to be a chemical and not a physical simulant. The starting sludge simulant is thin rheologically when compared to actual radioactive sludge. Except for GN71, the SRAT and SME products were also thin rheologically. Testing with simulants is helpful in showing trends as they are affected by process chemistry versus any absolute numbers.

\subsubsection{Rheology}

Rheological properties of slurries are known to depend on particle size, insoluble solids content, $\mathrm{pH}$, and ionic strength (molarity of ionic charges from cations and anions). For a given insoluble solids matrix, the major factor for SRAT and SME slurries has historically been the wt\% insoluble solids content. The effect of $\mathrm{pH}$ is not trivial. Flow curves were obtained for the SRAT and SME product slurries ${ }^{19}$. The measured rheology of all there slurries was very thin. Measurement of the actual waste rheology is planned in upcoming experiments with actual waste because this sludge simulant was designed to be a chemical, not a rheological simulant.

Rheological measurements were made at $25{ }^{\circ} \mathrm{C}$. Previously established flow curve protocols were used, assuming the Bingham plastic model.

The flow curves were modeled using the Bingham Plastic rheological model. 


$$
\tau=\tau_{0}+\eta \gamma
$$

$$
\begin{aligned}
& \tau_{0}=\text { Bingham plastic yield stress }\left(\mathrm{Pa} \text { or dynes } / \mathrm{cm}^{2}\right) \\
& \eta=\text { Bingham Plastic consistency or Bingham plastic viscosity, }(\mathrm{Pa}-\mathrm{sec} \text { or } \mathrm{cP}) \\
& \gamma=\text { Shear rate }\left(\mathrm{sec}^{-1}\right) \\
& \tau=\text { Shear stress }\left(\mathrm{Pa} \text { or dynes } / \mathrm{cm}^{2}\right)
\end{aligned}
$$

For the SRAT product, a rheogram was performed between 0 and $600 \mathrm{sec}^{-1}$. For the SME products, a rheogram was performed between 0 and $300 \mathrm{sec}^{-1}$. The SRAT products' shear stress and share rate were fit to a line between 75 and $300 \mathrm{sec}^{-1}$ with a slope of the consistency and the intercept is the yield stress. Due to the Taylor Vortices, the SME products' shear stress and share rate were fit to a line between 75 and 150 $\sec ^{-1}$ For SRAT products, the measured rheology of all the runs demonstrated there was a very low yield stress $(<2 \mathrm{~Pa})$ and low consistency $(3-6 \mathrm{cP}$, on lower end of window). For SME products, the measured rheology of all the runs demonstrated there was a very low yield stress $(<1 \mathrm{~Pa})$ and an acceptable consistency (14-22 cP, on lower end of window). The exception to this was that the $125 \%$ acid stoichiometry run had a very high yield stress and slightly high consistency. The 100 and $110 \%$ acid stoichiometry slurries were fast settling, making it a challenge to pull representative samples and subsamples, especially in the SME cycle. The consistency for the $100 \%$ stoichiometry runs was higher than the $110 \%$ acid stoichiometry. For each acid stoichiometry set, the run with the highest consistency was the run with the highest total solids (least water). The results are summarized in Table 3-45. The SRAT and SME product rheograms are summarized in Figure 3-30 and Figure 3-31. 
Table 3-45. SRAT Product and SME Product Rheology

\begin{tabular}{|c|c|c|c|c|c|c|c|c|c|}
\hline Acid Stoichiometry & \multicolumn{4}{|c|}{$100 \%$} & $125 \%$ & \multicolumn{4}{|c|}{$110 \%$} \\
\hline Run & GN70 & GN76 & GN74 & GN79 & GN71 & GN73 & GN75 & GN77 & GN78 \\
\hline Acid Ratio, Glycolic:Total & \multicolumn{2}{|c|}{0.583} & \multicolumn{2}{|c|}{0.545} & 0.550 & \multicolumn{4}{|c|}{0.522} \\
\hline " SRAT Total Solids & 28.30 & 27.26 & 28.03 & 27.65 & 25.95 & 27.60 & 28.04 & 27.97 & 27.65 \\
\hline SRAT Design Basis, Pa & \multicolumn{9}{|c|}{$1.5-5$} \\
\hline SRAT Up Yield Stress, Pa & 0.15 & 0.35 & 0.17 & 0.31 & 20.7 & 0.31 & 0.28 & 1.39 & 0.34 \\
\hline $\begin{array}{l}\text { SRAT Down Yield Stress, } \\
\mathrm{Pa}\end{array}$ & 0.07 & 0.26 & 0.10 & 0.25 & 19.3 & 0.24 & 0.20 & 1.24 & 0.25 \\
\hline SRAT Design Basis, cP & \multicolumn{9}{|c|}{$5-12$} \\
\hline SRAT Up Consistency, cP & 3.56 & 3.66 & 3.49 & 3.75 & 11.5 & 4.40 & 4.44 & 5.69 & 3.62 \\
\hline $\begin{array}{l}\text { SRAT Down Consistency, } \\
\text { cP }\end{array}$ & 3.69 & 3.80 & 3.57 & 3.85 & 13.6 & 4.47 & 4.55 & 5.86 & 3.75 \\
\hline SME Total Solids & 49.49 & 45.55 & 47.11 & 45.43 & 44.44 & 46.55 & 45.98 & 45.91 & 49.67 \\
\hline SME Design Basis, $\mathrm{Pa}$ & \multicolumn{9}{|c|}{$2.5-15$} \\
\hline SME Up Yield Stress, $\mathrm{Pa}$ & 1.32 & 1.18 & 1.14 & 1.37 & 38.3 & 1.03 & 0.47 & 1.36 & 1.16 \\
\hline $\begin{array}{l}\text { SME Down Yield Stress, } \\
\mathrm{Pa}\end{array}$ & 2.71 & 0.13 & 0.86 & 2.15 & 39.2 & $0 *$ & $0 *$ & $0 *$ & $0 *$ \\
\hline SME Design Basis, cP & \multicolumn{9}{|c|}{$10-40$} \\
\hline SME Up Consistency, cP & 12.3 & 9.05 & 10.9 & 10.9 & 70.1 & 8.46 & 8.33 & 7.82 & 9.78 \\
\hline $\begin{array}{l}\text { SME Down Consistency, } \\
\mathrm{cP}\end{array}$ & 10.2 & 16.8 & 14.9 & 11.1 & 44.0 & 19.4 & 18.3 & 17.6 & 21.3 \\
\hline
\end{tabular}

* Calculated yield stress values less than zero (not possible) are report as 0 in the table above.

Note: The color shading used in the above table is shown below (green is excellent, yellow is good, red is unacceptable)

\begin{tabular}{|l|l|}
\hline Within limits \\
\hline $22 x$ limits \\
\hline 2x limits \\
\hline
\end{tabular}


SRNL-STI-2014-00306

Revision 0

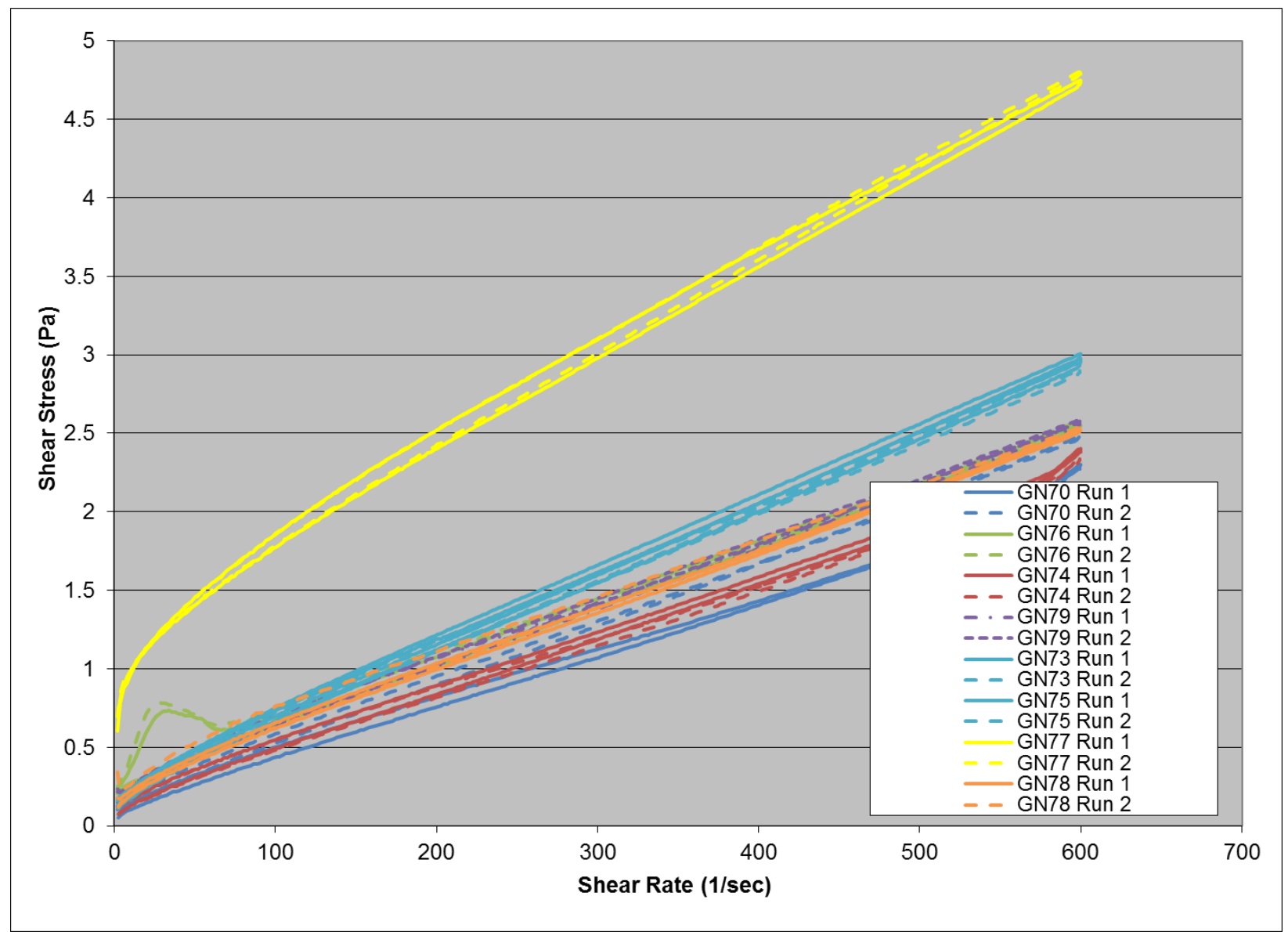

Figure 3-30. SRAT Product Rheology 


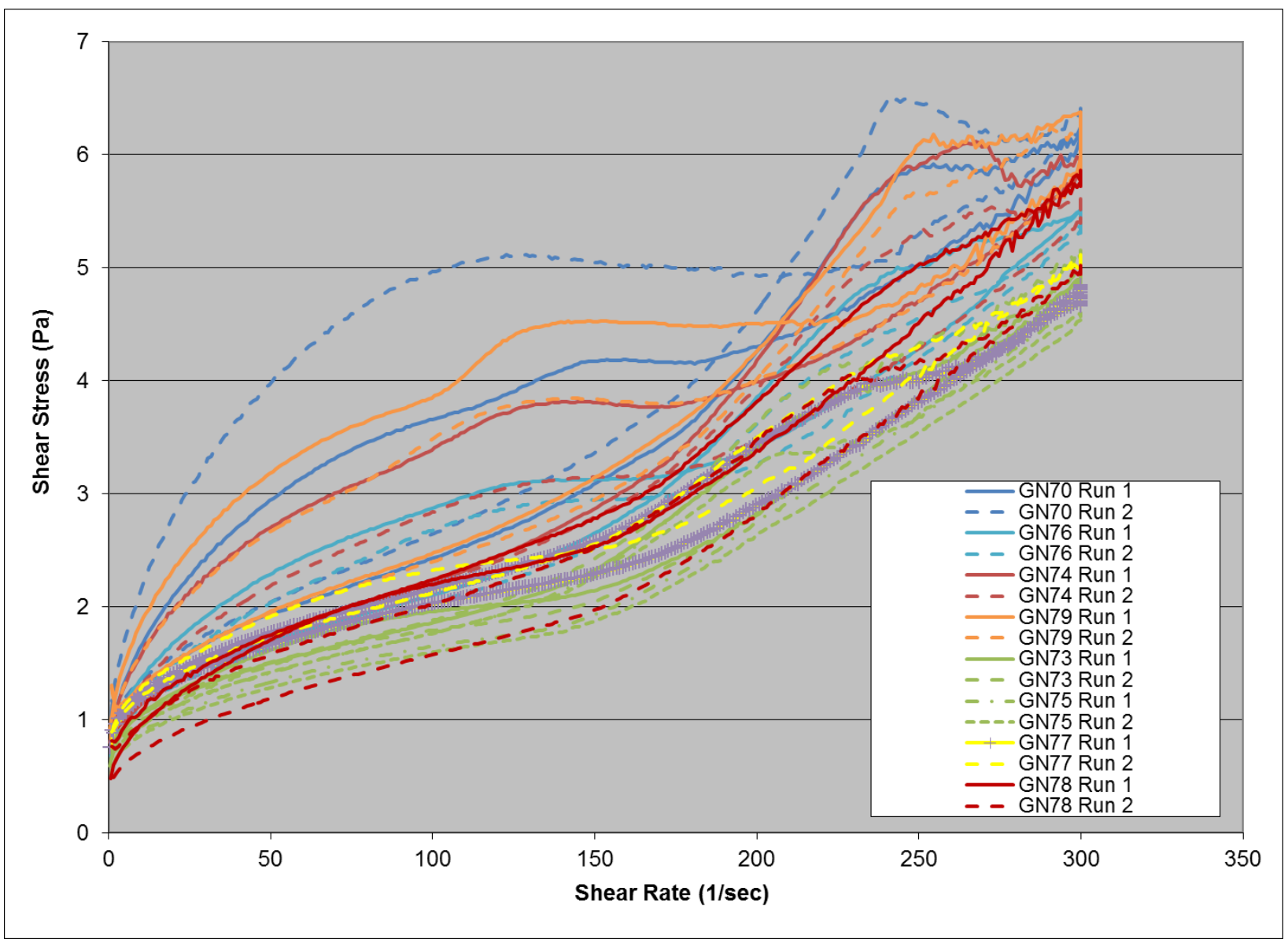

Figure 3-31. SME Product Rheology

The yield stress increased approximately 20 fold between an acid stoichiometry of $110 \%$ and $125 \%$. The consistency also increased by a factor of 2-3. There was little difference in rheology between $100 \%$ and $110 \%$ acid stoichiometry. This is likely the low rheology plateau between the low acid stoichiometry $(<100 \%$, not tested) and high acid stoichiometry $(>110 \%)$. The product rheology could have been thickened by removing more water from the SRAT and SME products. Since the slurries were so thin, no attempt was made to concentrate the products and get a rheology curve for each sample as the refractory sludge particles are not very representative of typical DWPF slurry feeds. The results are summarized in Figure 3-32. 


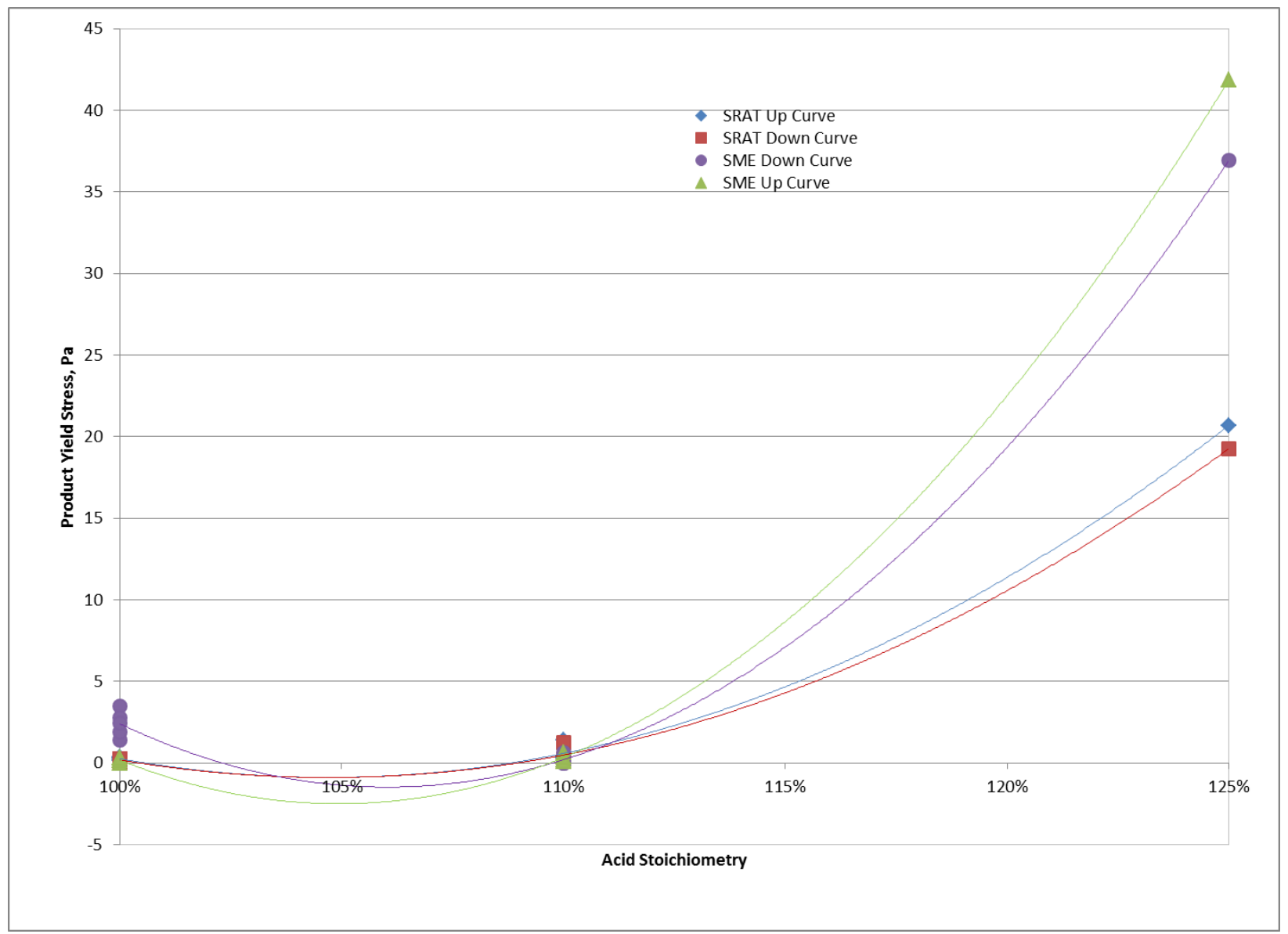

Figure 3-32. SRAT and SME Product Rheology versus Acid Stoichiometry

\subsubsection{Heat Transfer}

Mixing and heat transfer are important to maximizing reaction rates, minimum fouling of heating surfaces, and ensuring the slurry is homogeneous during processing. Some parameters important to heat transfer along with calculated heat transfer coefficients are summarized in Table 3-46. 
Table 3-46. Heat Transfer

\begin{tabular}{|c|c|c|c|c|c|c|c|c|}
\hline Acid Stoichiometry & \multicolumn{4}{|c|}{$100 \%$} & & \multicolumn{3}{|c|}{$110 \%$} \\
\hline Run & GN70 & GN76 & GN74 & GN79 & GN73 & GN75 & GN77 & GN78 \\
\hline Acid Ratio, Glycolic:Total & 0.5831 & 0.5831 & 0.5454 & 0.5454 & 0.5221 & 0.5221 & 0.5221 & 0.5221 \\
\hline Agitator Diameter, cm & 7.62 & 10.16 & 7.62 & 14.71 & 7.62 & 7.62 & 10.16 & 14.71 \\
\hline SRAT Mixing Speed, rpm & 299 & 592 & 349 & 273 & 399 & 386 & 505 & 279 \\
\hline SME Mixing Speed, rpm & 299 & 623 & 372 & 320 & 454 & 514 & 601 & 359 \\
\hline SRAT Tip Speed, cm/sec & 119 & 315 & 139 & 210 & 159 & 154 & 269 & 215 \\
\hline SME Tip Speed, cm/sec & 119 & 331 & 148 & 247 & 181 & 205 & 320 & 276 \\
\hline SRAT Power/Vol, W/L & 0.37 & 1.69 & 0.37 & 1.36 & 0.37 & 0.37 & 1.69 & 1.36 \\
\hline Heat Source & $\begin{array}{l}\text { Heating } \\
\text { Rods-2 }\end{array}$ & $\begin{array}{l}\text { Heating } \\
\text { Rods-4 }\end{array}$ & $\begin{array}{l}\text { Heating } \\
\text { Rods-2 }\end{array}$ & Steam & $\begin{array}{l}\text { Heating } \\
\text { Rods-2 }\end{array}$ & $\begin{array}{l}\text { Heating } \\
\text { Rods-2 }\end{array}$ & $\begin{array}{l}\text { Heating } \\
\text { Rods-4 }\end{array}$ & Steam \\
\hline Heating area, $\mathrm{cm}^{2}$ & 81.07 & 486.4 & 81.07 & 8,095 & 81.07 & 81.07 & 486.4 & 8,095 \\
\hline $\begin{array}{l}\text { SRAT Heat Transfer } \\
\text { Coefficient, W/cm } /{ }^{2} /{ }^{\circ} \mathrm{C}\end{array}$ & 0.179 & $\begin{array}{c}\text { Not } \\
\text { Measured }\end{array}$ & 0.170 & 0.151 & 0.168 & 0.170 & $\begin{array}{c}\text { Not } \\
\text { Measured }\end{array}$ & 0.125 \\
\hline $\begin{array}{l}\text { SME Heat Transfer } \\
\text { Coefficient, W/cm } /{ }^{2}{ }^{\circ} \mathrm{C}\end{array}$ & 0.172 & $\begin{array}{c}\text { Not } \\
\text { Measured }\end{array}$ & 0.153 & 0.148 & 0.145 & 0.162 & $\begin{array}{c}\text { Not } \\
\text { Measured }\end{array}$ & 0.125 \\
\hline
\end{tabular}

Note: The color shading used in the above table is shown below (green is excellent, yellow is good, red is unacceptable)

\begin{tabular}{|c|}
\hline$+/-0.02 \mathrm{~W} / \mathrm{cm}^{2} /{ }^{\circ} \mathrm{C}$ \\
\hline$+/-0.04 \mathrm{~W} / \mathrm{cm}^{2} /{ }^{\circ} \mathrm{C}$ \\
\hline$+/-0.10 \mathrm{~W} / \mathrm{cm}^{2} /{ }^{\circ} \mathrm{C}$ \\
\hline
\end{tabular}

The mixing speed varied considerably from run to run. The mixing was adjusted to ensure adequate mixing as judged visually by the researchers and/or technicians. The average mixing speed during the boiling portion of the SRAT and SME cycles was calculated. A better mixing parameter than revolutions per minute for comparing the three scales is agitator tip speed. Agitator tip speed is calculated as:

$$
\begin{aligned}
\text { Tip Speed } & =\pi * D * S \\
& \begin{aligned}
D & =\text { agitator blade diameter, } \mathrm{cm} \\
S & =\text { Mixer Speed in } \mathrm{rpm}
\end{aligned}
\end{aligned}
$$

The tip speed should be roughly equivalent at all scales. In the DWPF SRAT and SME, the tip speed is $311 \mathrm{~cm} / \mathrm{s}$ for low speed and 622 for high speed. High speed is only used for better mixing before sampling so $311 \mathrm{~cm} / \mathrm{s}$ is a good target for scale testing. Note that in most of the runs, the tip speed was lower than $311 \mathrm{~cm} / \mathrm{s}$. Throughout the runs, the mixing was judged adequate (mixing at surface and sides of kettle) at the speeds used throughout the runs.

Power per unit volume is another parameter that is more often used to scale up mixing. The power was estimated using Equation [14].

$$
\text { Power per unit volume, } H P / L=P / V=N p * \mu * S^{3} * D^{5} * 0.001341 / 0.8
$$


$D=$ agitator blade diameter, $\mathrm{cm}$

$S=$ Mixer Speed in rpm

$\mu=3.62$ cp

$N p=$ Power Number $=1.37$ for Pitched BladeTurbine

The heat transfer was measured during experiments. In the 4-L rigs, the calculated heat transfer coefficient was $0.17 \mathrm{~W} / \mathrm{cm}^{2} /{ }^{\circ} \mathrm{C}$ during the SRAT cycles and $0.16 \mathrm{~W} / \mathrm{cm}^{2} /{ }^{\circ} \mathrm{C}$ during the SME cycles. The heat transfer could not be estimated in the 22-L rigs using the measured rod temperature as the rod thermocouple was very close to the "skin" of the rod and was approximately the same temperature as the bulk slurry. The calculated heat transfer coefficients were unrealistically high. The heat transfer coefficient in the 220-L rigs was calculated using the steam condensate generation rate (no steam flow controller was available) and the calculated steam temperature calculated from the measured steam pressure. The calculated steam temperature was used instead of the measured steam temperature as it gave a much more realistic heat transfer coefficient result than the measured steam temperature (Figure 3-33). Note the unrealistically high calculated heat transfer coefficients in the graph, which leads to an overestimate of the heat transfer. Based on the calculated steam temperature, the calculated heat transfer coefficient was $0.125-0.15 \mathrm{~W} / \mathrm{cm}^{2} /{ }^{\circ} \mathrm{C}$ during the SRAT and SME cycles.

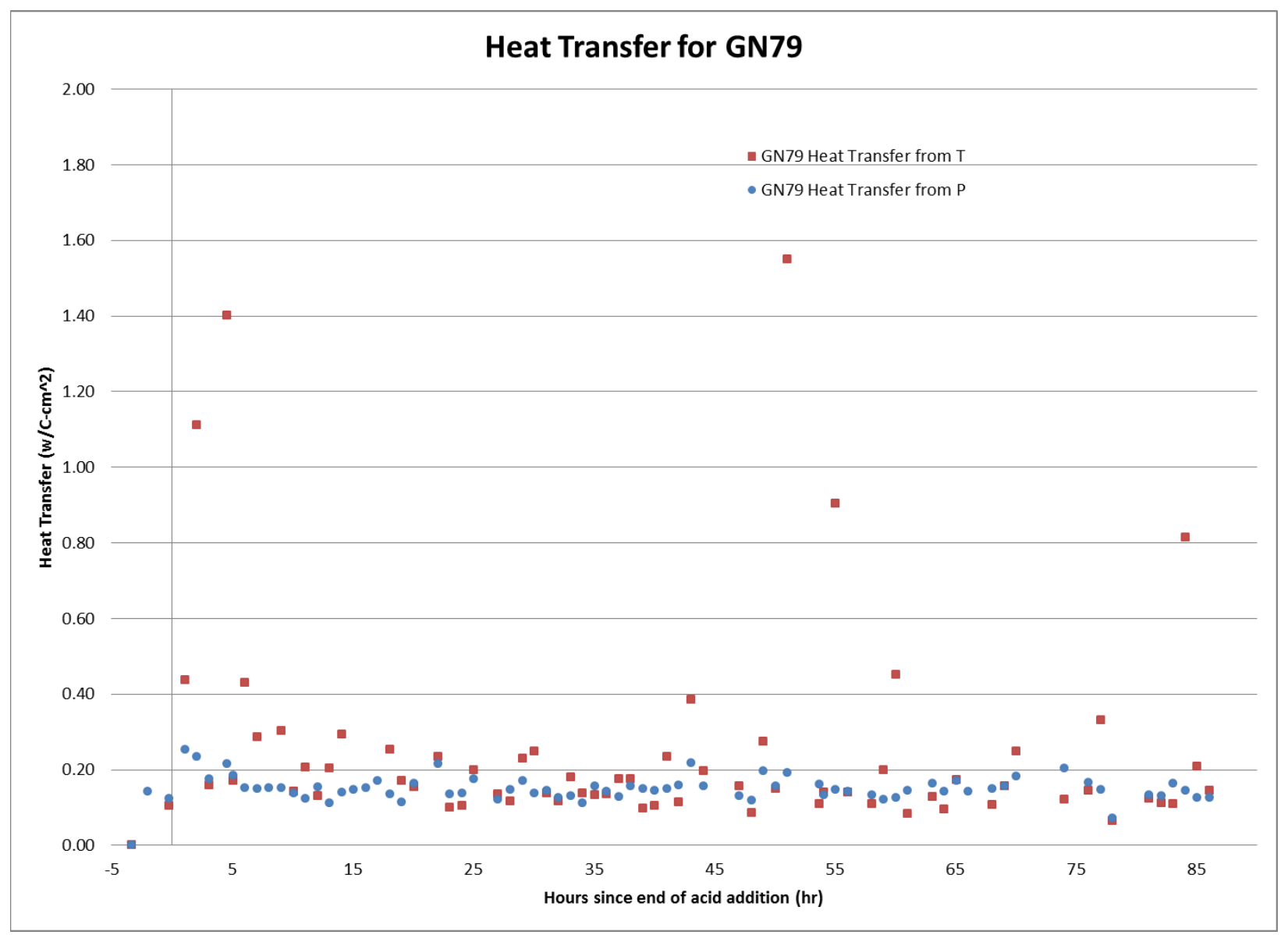

Figure 3-33. GN79 Calculated Heat Transfer Coefficient Using Measured Steam and Calculated Steam Temperature 
The calculated heat transfer coefficient for GN79 (100\% acid stoichiometry) was approximately 20\% higher than GN78 (110\% acid stoichiometry), as shown in Figure 3-34.

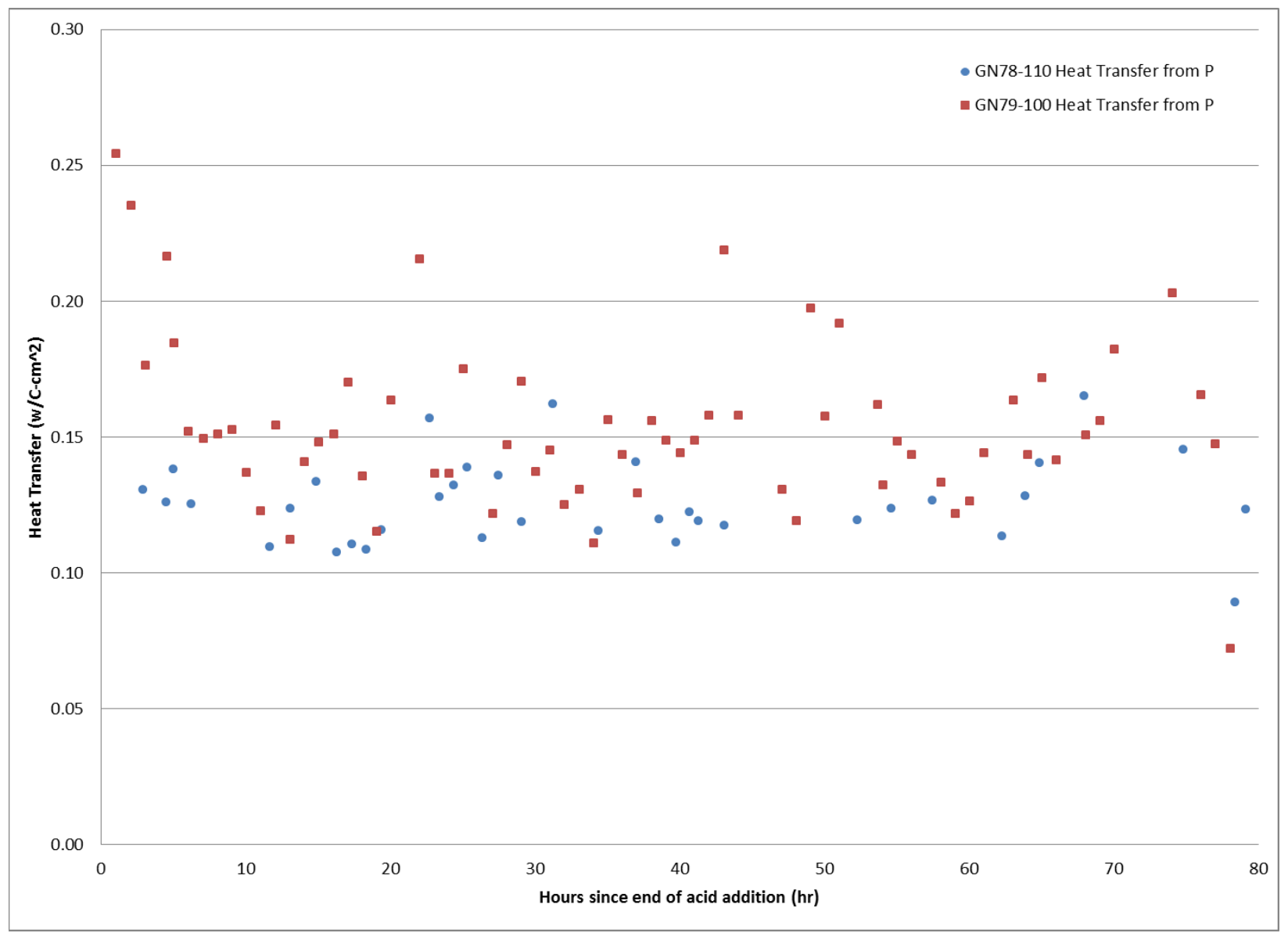

Figure 3-34. SRAT and SME Cycle Heat Transfer Coefficient Comparison for GN78 and GN79

The 220-L vessel stainless steel lid was designed with 1 inch diameter camera ports to allow internal observation during processing. As a result of the volume and quantity of samples collected and typical concentration of the SRAT and SME products, the upper three rings of the steam coil were exposed during processing (see Figure 3-35). During the SRAT and SME cycles, there was no apparent fouling. An indication of fouling would be a decrease in process temperature requiring additional heat to maintain steady temperature. No fouling of the steam coil was observed. Upon completion of the SME cycle, the 220-L vessel was emptied and rinsed with water. Any slurry material on the coil was easily rinsed off. Figure 3-36 and Figure 3-37 show the steam coil at the end of testing of each SME cycle. 


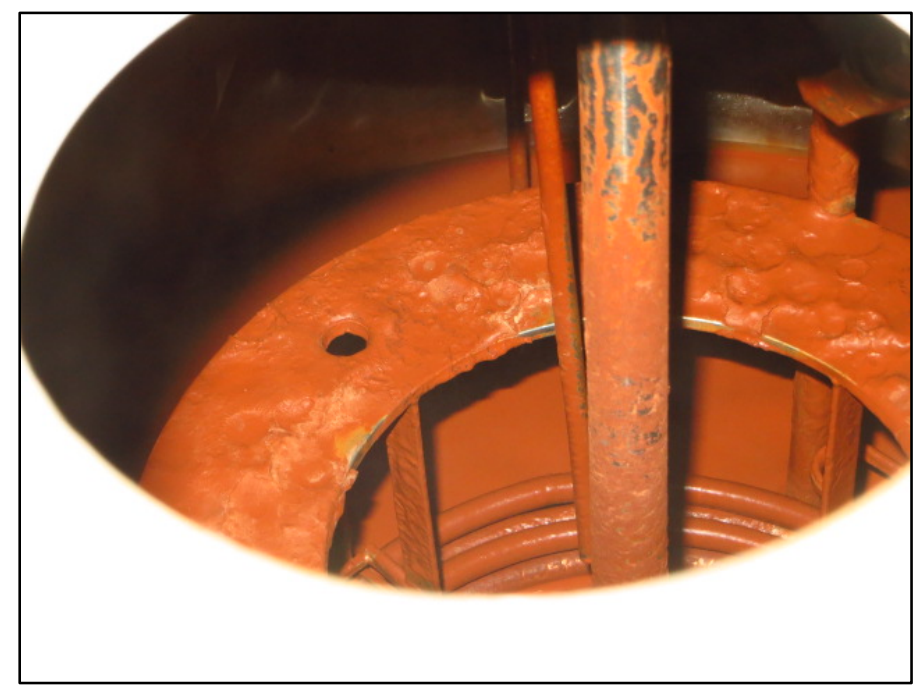

Figure 3-35: Steam coil at the end of GN 78 SRAT cycle

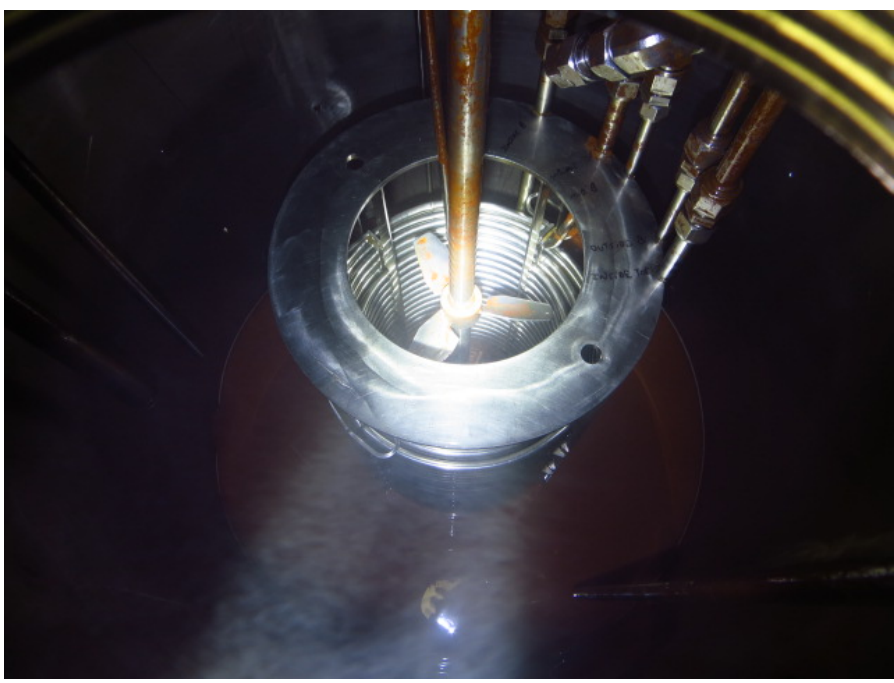

Figure 3-36: Steam coil after end of GN78 SME cycle 
SRNL-STI-2014-00306

Revision 0

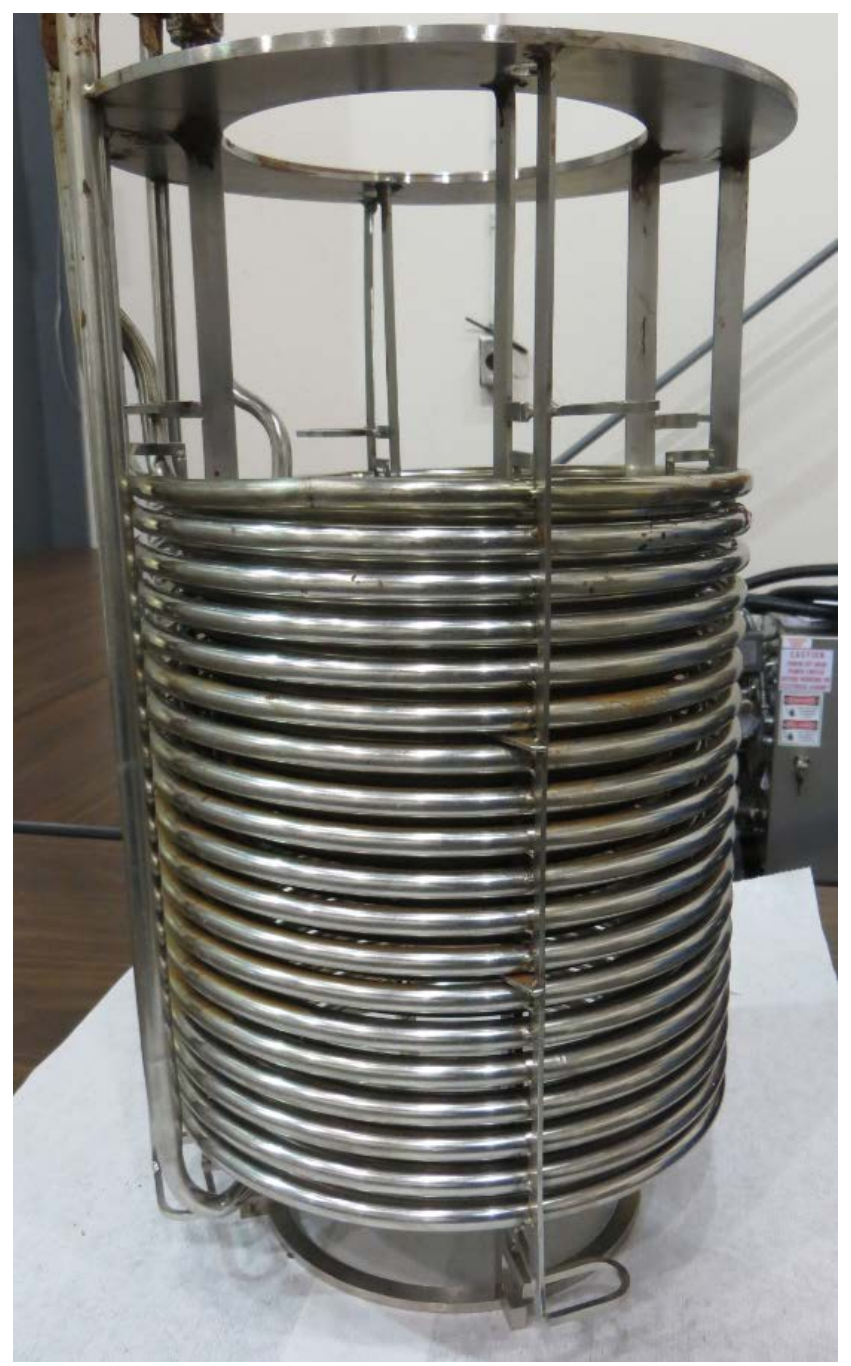

Figure 3-37: Steam coil after end of GN79 SME cycle

\subsubsection{Foam/Antifoam}

Antifoam has been added to the SRAT and SME since startup due to the foaming tendency of the SRAT and SME materials together with the gas formation due to offgas generation $\mathrm{NO}, \mathrm{NO}_{2}$, and $\mathrm{N}_{2} \mathrm{O}, \mathrm{CO}_{2}$, and the generation of water vapor during boiling. As was discussed earlier, the antifoam began degrading upon dilution and continues degrading after being added to the SRAT or SME. Note that in all runs, diluted antifoam (Antifoam 747 from Siovation Lot\#111128-0613) was prepared before the run and the diluted antifoam continued to degrade as the experiments progressed. By the time the antifoam was added it had partially degraded and was not as effective as undiluted antifoam would have been.

The degradation products that are formed during storage of the diluted antifoam are volatile at SRAT and SME processing conditions and lead to high concentrations of flammable antifoam degradation products immediately after the diluted antifoam is added. To prevent this antifoam degradation peak, DWPF has eliminated adding diluted antifoam. There is still antifoam degradation during processing but the peak concentration of the antifoam degradation products is at least an order of magnitude smaller than the degradation product peak due to antifoam dilution. 
The antifoam strategy for these runs is summarized in Table 3-47. Note that less antifoam was added during SRAT processing than was added during SB8 nitric-formic acid flowsheet testing. Also note that the antifoam additions were added when they were needed, so no antifoam added was added prior to $\mathrm{pH} 10$ since gas evolution doesn't peak until about $\mathrm{pH}$ 5.5. Also, antifoam was added closer to boiling, not while cool, to maximize its antifoam effectiveness.

No foamovers were noted during processing. There were small carryover events of entrained slurry based on technician notes on runs GN70, GN73, and GN76 (GN76 started very full so GN77 was completed with a lower volume of starting sludge). Based on the post SRAT MWWT sample cation analysis, run GN76 was highest in Fe, likely due to the small carryover event.

Table 3-47. SRAT and SME Antifoam Strategy for Nitric-Glycolic and Nitric-Formic Flowsheets

\begin{tabular}{||l|l|l||}
\hline & Nitric-Glycolic Acid & SB8 Nitric-Formic Acid \\
\hline Prior to nitric acid addition & & $200 \mathrm{mg} / \mathrm{kg}$ (1.38 gallons) \\
\hline At pH 10 (during nitric) & $100 \mathrm{mg} / \mathrm{kg}(0.69$ gallons) & \\
\hline Prior to reducing acid addition & $100 \mathrm{mg} / \mathrm{kg}(0.69$ gallons $)$ & $100 \mathrm{mg} / \mathrm{kg}(0.69$ gallons $)$ \\
\hline Prior to SRAT boiling & $100 \mathrm{mg} / \mathrm{kg}(0.69$ gallons $)$ & $500 \mathrm{~m} / \mathrm{kg}(3.45$ gallons $)$ \\
\hline Every 12 hours during SRAT & $100 \mathrm{mg} / \mathrm{kg}(0.69$ gallons $)$ & $100 \mathrm{mg} / \mathrm{kg}(0.69$ gallons $)$ \\
\hline Total SRAT & $600 \mathrm{mg} / \mathrm{kg}(4.14$ gallons $)$ & $1,100 \mathrm{mg} / \mathrm{kg}(7.59$ gallons $)$ \\
\hline Prior to SME cycle & & $100 \mathrm{mg} / \mathrm{kg}(0.69$ gallons $)$ \\
\hline Prior to SME boiling & $100 \mathrm{mg} / \mathrm{kg}(0.69$ gallons $)$ & \\
\hline Every 12 hours in SME & $100 \mathrm{mg} / \mathrm{kg}(0.69$ gallons $)$ & $100 \mathrm{mg} / \mathrm{kg}(0.69$ gallons $)$ \\
\hline Total SME & $200 \mathrm{mg} / \mathrm{kg}(1.38$ gallons $)$ & $200 \mathrm{mg} / \mathrm{kg}(1.38$ gallons $)$ \\
\hline
\end{tabular}

Foaming is a liquid surface phenomena so the cross sectional area determines the flux at the surface. The larger the scale of the test, the larger the flux at boiling. So the testing at 220-L was the most significant regarding foaming. The boiling flux is summarized in Table 3-48. The point is that no foamover occurred even in the 220-L SRAT. The antifoam strategy used is acceptable for the processing of the SB8 sludge simulant. But processing of actual waste in DWPF at the higher flux may require more frequent antifoam additions or larger antifoam additions.

Table 3-48. Calculated Boiling Flux in SRAT for Scaled Experiments

\begin{tabular}{|c|c|c|c|c|}
\hline & 4-L & 22-L & 220-L & DWPF \\
\hline SRAT Diameter & 5.9 inches & 11.6 inches & 23.2 inches & $12 \mathrm{ft}$ \\
\hline Boilup Rate & $2.71 \mathrm{~g} / \mathrm{min}$ & $15.69 \mathrm{~g} / \mathrm{min}$ & $102.39 \mathrm{~g} / \mathrm{min}$ & $5,000 \mathrm{lb} / \mathrm{hr}$ \\
\hline Boiling Flux, $\mathrm{lb} / \mathrm{hr} / \mathrm{ft}^{2}$ & 2.90 & 5.08 & 7.37 & 44.2 \\
\hline
\end{tabular}

No analysis of the recovered mercury was completed. There are several analyses that might be useful to determine the impurities in the mercury and the forms of mercury that are present in the MWWT. This knowledge may help in improving mercury recovery and understand the extent of entrainment/foamovers. First, the mercury should be submitted for a series of tests to determine the forms of mercury present, including elemental, organic, and inorganic. Second, the collected mercury should be digested and the resulting liquid submitted for anion and cation analysis. This analysis would help determine the extent of foamovers or entrainment events that may have been missed during testing.

\subsection{REDOX}

Prediction of REDOX has been poor since the initiation of the nitric-glycolic acid flowsheet. ${ }^{21}$ In many of the runs, the melter feed has been overly reducing. The analytical method led to difficulties in predicting more accurate destruction/creation of glycolate/oxalate that compounded the ability to determine if the coefficient for glycolate was adequate. 
A study developed a new REDOX method and REDOX equation. In addition, a study has been completed to improve the measurement of glycolate and oxalate by using a caustic quench to improve the accuracy of the anion measurements. ${ }^{20}$ The latest results from the development of the REDOX equation and improved anion method have been incorporated into the analysis below. All anion measurements used to predict REDOX used the new caustic quench method. Equation [15] is used to predict the glass REDOX based on analytical results of the SME product.

The closed crucible Hot (CCHot) REDOX method was used to prepare the glass for the REDOX analyses.

$$
\begin{aligned}
\frac{F e^{2+}}{\sum F e}=0.24 & +0.20 *(2 F+4 C+6 G+4 O-5 N) * 45 / T \\
\mathrm{~F} & =\text { formate }(\mathrm{mol} / \mathrm{kg} \text { feed }) \\
\mathrm{C} & =\text { coal }(\text { carbon) }(\mathrm{mol} / \mathrm{kg} \text { feed }) \\
\mathrm{O} & =\text { oxalate }(\text { soluble and insoluble) }(\mathrm{mol} / \mathrm{kg} \text { feed }) \\
\mathrm{G} & =\text { glycolate }(\mathrm{mol} / \mathrm{kg} \text { feed }) \\
\mathrm{N} & =\text { nitrate }+ \text { nitrite }(\mathrm{mol} / \mathrm{kg} \text { feed }) \\
\mathrm{Mn} & =\text { manganese }(\mathrm{mol} / \mathrm{kg} \text { feed }) \\
\mathrm{T} & =\text { Total Solids }(\mathrm{wt} \%)
\end{aligned}
$$

\begin{tabular}{|c|c|c|c|c|c|c|c|c|}
\hline \multirow{2}{*}{$\begin{array}{l}\text { Acid Stoichiometry } \\
\text { Run }\end{array}$} & \multicolumn{4}{|c|}{$100 \%$} & & \multicolumn{3}{|c|}{$110 \%$} \\
\hline & GN70 & GN76 & GN74 & GN79 & GN73 & GN75 & GN77 & GN78 \\
\hline Acid Ratio, Glycolic:Total & 0.5831 & 0.5831 & 0.5454 & 0.5454 & 0.5221 & 0.5221 & 0.5221 & 0.5221 \\
\hline SME Formate, $\mathrm{mol} / \mathrm{kg}$ & 0.01 & 0.04 & 0.02 & 0.01 & 0.01 & 0.01 & 0.01 & $<0.01$ \\
\hline SME Glycolate, mol/kg & 0.51 & 0.50 & 0.63 & 0.52 & 0.54 & 0.56 & 0.52 & 0.58 \\
\hline SME Oxalate, $\mathrm{mol} / \mathrm{kg}$ & 0.02 & 0.04 & 0.04 & 0.03 & 0.03 & 0.03 & 0.03 & 0.03 \\
\hline SME Nitrate, mol/kg & 0.64 & 0.62 & 0.79 & 0.67 & 0.82 & 0.87 & 0.78 & 0.84 \\
\hline SME Mn, mol/kg & 0.19 & 0.17 & 0.17 & 0.17 & 0.17 & 0.18 & 0.17 & 0.16 \\
\hline SME Total Solids, wt\% & 47.1 & 45.6 & 49.3 & 45.9 & 46.6 & 46.0 & 45.9 & 49.7 \\
\hline \multicolumn{9}{|l|}{ REDOX } \\
\hline Target $\mathrm{Fe}^{2+} / \Sigma \mathrm{Fe}$ & $\sim 0.3$ & $\sim 0.3$ & $\sim 0.2$ & $\sim 0.2$ & $\sim 0.2$ & $\sim 0.2$ & $\sim 0.2$ & $\sim 0.2$ \\
\hline CCHot, $\mathrm{Fe}^{2+} / \Sigma \mathrm{Fe}$ & 0.30 & 0.24 & 0.11 & 0.12 & 0.15 & 0.03 & 0.14 & 0.10 \\
\hline Prediction, $\mathrm{Fe}^{2+} / \Sigma \mathrm{Fe}$ & 0.22 & 0.27 & 0.240 & 0.211 & 0.10 & 0.07 & 0.11 & 0.13 \\
\hline
\end{tabular}

It should be noted that the REDOX of runs GN70 and GN76 should be higher than the REDOX of runs GN74 and GN79 due to the higher acid ratio. So although in most of the tables all of the $100 \%$ stoichiometry data was treated together, it is important to separate these two pairs of runs as the REDOX should be different. Blue text is used to highlight the difference in the Table 3-49 below visually.

Table 3-49. REDOX of Glass (CC Hot) Produced from SME Product

Note: The color shading used in the above table is shown below (green is excellent, yellow is good, red is unacceptable)

\begin{tabular}{|l|l|l|l|l|}
\hline$+/-0.05$ & & $+/-0.10$ & & $+/-0.20$ \\
\hline
\end{tabular}




\subsection{Conclusions}

Savannah River Remediation (SRR) is considering using glycolic acid as a replacement for formic acid in Sludge Receipt and Adjustment Tank (SRAT) processing in the Defense Waste Processing Facility (DWPF). Catalytic decomposition of formic acid is responsible for the generation of hydrogen, a potentially flammable gas, during processing. To prevent the formation of a flammable mixture in the offgas, an air purge is used to dilute the hydrogen concentration below the $60 \%$ of the Composite Lower Flammability Limit (CLFL). The offgas is continuously monitored for hydrogen using Gas Chromatographs (GCs). Formic acid is much more toxic and volatile than glycolic acid, so a formic acid spill would lead to the release of much larger quantities to the environment. Switching from formic acid to glycolic acid is expected to eliminate the hydrogen flammability hazard leading to lower air purges, thus downgrading of Safety Significant GCs to Process Support GCs, and minimizing the consequence of a glycolic acid tank leak in DWPF. Overall this leads to a reduction in process operation costs and an increase in safety margin.

Experiments were completed in an attempt to answer the question, "Does the nitric-glycolic acid flowsheet testing completed in 4-L experiments scale up to 22-L and 220-L experiments?” Ten process demonstrations of the sludge-only flowsheet for SRAT and Slurry Mix Evaporator (SME) cycles were performed using Sludge Batch 8 (SB8)-Tank 40 simulant. No Alpha Removal Process (ARP) product or strip effluent was added during the runs. Six experiments were completed at the 4- $\mathrm{L}$ scale, two experiments were completed at the 22-L scale, and two experiments were completed at the 220-L scale. Experiments completed at the 4-L scale (100 and 110\% acid stoichiometry) were repeated at the 22-L and 220-L scale for scale comparisons. The main differences between the runs were scale, acid stoichiometry and the acid mix (\% of glycolic acid). The primary objective of the testing was to determine whether important processing parameters are impacted by the scale of the experiment.

The chemistry and processing were virtually identical at the three scales tested. There were a few areas where a parameter did change with scale (such as nitrite to nitrate conversion and mercury collection) but nitrite to nitrate conversion is sensitive to internal reflux and was expected to change with scale. Two potential flammability hazards, namely hydrogen and ammonia generation, were reduced by more than a factor of ten by replacing formic acid with glycolic acid and this was not impacted by the testing scale.

Some highlights from the experiments include:

- The experimental work was completed without significant process deviations or process upsets. The experiments were completed as directed by the principal investigator meaning the planned mass for sludge, acids, SRAT dewater, canister decontamination water addition and dewater, and process frit addition and dewater met planned targets as did the addition rates for the reagents and the time at temperature for the experiments.

- More than 800 liquid samples were pulled and several-hundred-thousand offgas samples from three offgas analyzers (gas chromatograph, mass spectrometer, and Fourier transform infrared) were collected and tracked throughout the experiments for an improved understanding of the process chemistry.

- A lower SRAT air purge (230 standard cubic feet per minute, scfm for nitric-formic acid flowsheet, $94 \mathrm{scfm}$ for nitric-glycolic acid flowsheet) was used due to the low hydrogen generation.

- The sample and offgas data were used to complete mass balances for the reactive species during SRAT and SME processing. These mass balances for carbon and nitrogen species demonstrated that the process chemistry was equivalent at all three scales tested.

- Very low hydrogen generation was experienced at all scales (except Run GN71 during rod fouling where the surface temperature of the rod significantly exceeded the maximum possible steam coil temperature). The upper 95\% confidence bound on the GC peak SRAT hydrogen generation was 
6.6E-3 lb/hr DWPF Scale in run GN70. The upper 95\% confidence bound on the GC peak SME hydrogen generation was 8.7E-3 lb/hr DWPF Scale in runs GN79.

- The ammonia generation was very low. The condensate generated during testing was very low in ammonium. The scrub solution used to remove ammonia from the offgas was also very low in ammonium. As a result, the Slurry Mix Evaporator Condensate Tank (SMECT) pH limit of 1-3 is not necessary for the nitric-glycolic acid flowsheet and the need for the ammonia scrubbers should be re-evaluated. Very low ammonia generation $(<5 \%$ of nitric-formic acid flowsheet) was experienced at all scales.

- The $\mathrm{pH}$ of the $100 \%$ acid stoichiometry runs averaged 7.2 in the SRAT and 7.3 in the SME product. The $\mathrm{pH}$ of the $110 \%$ acid stoichiometry runs averaged 4.7 in the SRAT and 5.2 in the SME product. The SRAT and SME product $\mathrm{pHs}$ are significantly lower than comparable nitricformic acid flowsheet experiments. This low $\mathrm{pH}$ results in lower yield stress and minimizes the release of ammonia to the offgas.

- Most of the testing was completed at KMA stoichiometry of $100 \%$ and $110 \%$. This is equivalent to a Hsu Acid stoichiometry of $107 \%$ and $117 \%$. The true stoichiometry for this flowsheet is actually much higher due to the fact that glycolic acid has more reducing power per mol than formic acid.

- The mercury collection in the Mercury Water Wash Tank (MWWT) was slightly higher than is seen in nitric-formic acid flowsheet runs. Mercury recovery in the MWWT averaged $19 \%$ in the $100 \%$ KMA runs and $43 \%$ in the $110 \%$ KMA runs. The higher acid stoichiometry runs had higher mercury collection than the lower acid stoichiometry runs without increased hydrogen generation.

- The measured REDOX for glass produced from SME products using the closed crucible hot method varied from 0.03 to $0.30 \mathrm{Fe}^{2+} / \Sigma \mathrm{Fe}$. The REDOX for the duplicated runs targeted 0.20 $\mathrm{Fe}^{2+} / \Sigma \mathrm{Fe}$ and averaged $0.15 \mathrm{Fe}^{2+} / \Sigma \mathrm{Fe}$.

- Nitrite and carbonate in the sludge were completely destroyed during SRAT processing. Nitrite to nitrate conversion averaged 35\% in the 100\% KMA runs and 50\% in the $110 \%$ KMA runs. Nitrite reacts to form $\mathrm{NO}, \mathrm{N}_{2} \mathrm{O}$, and $\mathrm{NO}_{2}$, but very little ammonia. Some oxalate and formate are produced during SRAT processing.

- Some glycolate is consumed through acid/base and reduction reactions. The SRAT glycolate destruction averaged $18 \%$ in the $100 \%$ KMA runs and 15\% in the $110 \%$ KMA runs.

- No foamovers were noted during processing. There were small carryover events of entrained slurry in runs GN70, GN73, and GN76. The antifoam strategy used in these runs was effective in controlling foam at all scales. The antifoam did degrade over time based on offgas and slurry analyses, as it does in the nitric-formic acid flowsheet. No difference in antifoam degradation is seen compared to nitric-formic acid flowsheet experiments.

- The condensate is primarily water with appreciable nitric acid from the scrubbing of $\mathrm{NO}_{\mathrm{x}}$ from the offgas. Silicon was the most significant cation detected in the condensate, likely an antifoam degradation product. Very little ammonium was detected in the condensate and ammonia scrub solution. Little mercury was dissolved in the condensate.

- The SRAT and SME products were very thin rheologically. The SRAT product yield stress was less than $1 \mathrm{~Pa}$ (design basis $\geq 1.5 \mathrm{~Pa}$ ) and the SME product yield stress was less than $1 \mathrm{~Pa}$ (Design basis $\geq 12.5 \mathrm{~Pa}$ ). The exception to this was run GN71, which was completed at the highest acid stoichiometry (125\%). The GN71 SRAT product yield stress was $20 \mathrm{~Pa}$ (DWPF design basis $\leq 5$ $\mathrm{Pa}$ ) and the GN71 SME product had a yield stress of $40 \mathrm{~Pa}$ (DWPF design basis $\leq 15 \mathrm{~Pa}$ ), and the GN71 SRAT and SME consistency was just outside the design basis. The measured rheology of all the slurries was very thin. Measurement of the actual waste rheology is planned in upcoming experiments with actual waste because this sludge simulant was designed to be chemical, not a rheological simulant. 


\subsection{Recommendations}

Based on the scaled testing completed, the nitric-glycolic acid flowsheet is recommended for implementation in DWPF CPC because of the successful testing that has been completed to date.

\section{Recommendations Prior to Implementation of the Nitric-Glycolic Flowsheet in DWPF}

Based on the scaled testing completed, the nitric-glycolic acid flowsheet is recommended for implementation in DWPF Chemical Process Cell (CPC) because of the successful testing that has been completed to date.

\section{Recommendations Prior to Implementation of the Nitric-Glycolic Flowsheet:}

1. Re-evaluate the REDOX data if a new REDOX method or REDOX equation has been developed for the nitric-glycolic acid flowsheet. This report should be revised to update the predictions based on the best REDOX equation.

2. Re-evaluate the acid stoichiometry calculation if a revised acid stoichiometry equation is developed for the nitric-glycolic acid flowsheet. This report should be revised to update the predictions based on the best acid stoichiometry equation.

Recommendations Not Required Prior to Implementation of the Nitric-Glycolic Flowsheet:

1. Calculate the kinetics for the reactions of carbonate, nitrite, and other components based on the data collected during this study. Both the equilibrium and kinetics of the reactions are needed to enhance the understanding of the chemistry involved in the nitric-glycolic acid flowsheet.

2. Based on the hydrogen generation observed during the scaled testing, DWPF should evaluate the need/requirements for the GCs. Continued operation of GCs provides important processing information that is especially valuable at the start of a new sludge batch or when processing difficulties are experienced.

3. A recent antifoam degradation study was completed. ${ }^{23}$ Based on the lessons learned from this study, the antifoam is now added without dilution with water. The antifoam degradation products measured in the offgas and condensate during this study are not prototypic of current DWPF processing since the antifoam was diluted with water prior to addition. The best sample for evaluating the concentration of antifoam degradation products in condensate would be a DWPF SMECT or Recycle Collection Tank (RCT) sample. In addition, antifoam degradation products should be measured in both the offgas and condensates during the Sludge Batch 9 (SB9) flowsheet simulant testing.

The complete discussion of chemistry was not part of this study but the data generated here was included in the chemistry analysis. A report that brings together all of the chemistry data to date (including data in this report) has been issued. ${ }^{11}$ It is recommended that analysis of the following data would be useful for better understanding the DWPF processing using the nitric-glycolic acid flowsheet.

\section{Recommendations for Improving Sludge Processing in DWPF}

Process improvement ideas were developed during this testing the may impact DWPF processing either with the nitric-formic acid flowsheet or the nitric-glycolic acid flowsheet.

1. The condensate produced during acid addition and in the first few hours of boiling is very acidic $(\mathrm{pH}<2)$. During periods of SRAT dewater (reflux valve closed), the acidic condensate is collected in the MWWT and overflows to the SMECT. During periods of SRAT reflux (reflux valve open), the acidic condensate is collected in the MWWT and overflows to the SRAT. The acidic condensate can dissolve some of the elemental mercury in the MWWT or SMECT, leading to lower mercury collection. Mercury recovery in DWPF could be improved by controlling the $\mathrm{pH}$ of the SMECT and MWWT at a higher $\mathrm{pH}$ (5-7) to minimize the dissolution of mercury during processing and during storage. In addition, pumping the MWWT mercury to the mercury cell each 
batch is recommended to minimize the mercury dissolution between batches. Lastly, refluxing the condensate back to the SRAT during periods of high $\mathrm{NO}_{x}$ production could minimize the dissolution of mercury in the Slurry Mix Evaporator Condensate Tank (SMECT) and may lead to higher mercury collection in the SMECT.

2. The 220-L scale equipment is well designed to study foaming and ammonia scrubbing, as well as mercury reduction, stripping, coalescence and decanting. At the larger scale, it would be much easier to study these processing parameters.

3. Due to the low ammonia production, the ammonia scrubbers are not needed for offgas ammonia removal as long as sufficient acid is added to keep the SRAT and SME pH below 7. The scrubbers are needed for cooling, along with $\mathrm{NO}_{\mathrm{x}}$, mercury, and particulate removal, but the need to maintain a $\mathrm{pH}$ of $1-3$ in the SMECT is eliminated.

4. A larger nitrite to nitrate conversion factor should be used in DWPF than is measured in 4-L labscale testing due to the larger DWPF scale.

5. The products from these runs should be maintained for use in future studies. It would be ideal for use in rheology, REDOX, melt rate, mercury, and heel studies.

\subsection{Future Study}

A recent antifoam degradation study was completed. ${ }^{23}$ Based on the lessons learned from this study, the antifoam degradation products should be measured in prototypic DWPF processing. The best sample would be a DWPF SMECT or RCT sample. The condensate from this study might also be a good sample although a sample from the SB9 flowsheet simulant testing might more prototypic.

During previous simulant testing with an ammonia scrubber, the scrub solution $\mathrm{pH}$ was less than 3 . This testing has identified that the collection of mercury might be more effective if the ammonia scrubbers utilize a higher $\mathrm{pH}$ scrub solution. Testing with a higher $\mathrm{pH}$ scrub solution is recommended.

Suggestions were made to improve future experiments for understanding mercury stripping, mercury dissolution and mercury decanting:

- Determine the forms of mercury produced in CPC processing (elemental mercury, calomel, methyl mercury, etc.).

- $\quad$ Determine the fraction of soluble and insoluble mercury species.

- Complete back to back DWPF prototypic SRAT testing that includes a heel of mercury in the MWWT and SMECT, hot SRAT condenser outlet temperature, mercury in offgas piping, SRAT condenser, and tubing between SRAT condenser and MWWT to better simulate prototypic DWPF processing. Pull more samples during the latter part of glycolic acid addition and the early part of SRAT dewatering.

- Determine if mercury collection is increased by refluxing the SRAT condensate (not dewatering) for the first 3 hours of SRAT boiling. This would return any dissolved mercury back to the SRAT allowing collection in the MWWT at a time when the condensate is less acidic.

- Determine whether $\mathrm{pH}$ control of the MWWT can increase mercury recovery

- Determine whether $\mathrm{pH}$ control of the SMECT can increase mercury recovery

- Determine whether a coalescer will improve the recovery of mercury in the MWWT

The following TTR requests were not completely satisfied by this testing.

- Mass accumulated on the heating rods during the experiment was not measured since minimal deposits were noted

- Concentrate slurry at end of SRAT and SME cycle as much as possible to produce slurry for rheology study. Determining rheology for a series of total/insoluble solids for SRAT and SME Cycles should be done with radioactive sludge not simulant. 


\subsection{References}

1. B.R. Pickenheim and M.E. Stone, "SRAT Alternative Reductant Feasibility Assessment - Phase I," Savannah River National Laboratory, Aiken, SC, SRNL-STI-2009-00120, Rev 0, 2009.

2. B.R. Pickenheim, M.E. Stone, and J.D. Newell, "Glycolic-Formic Acid Flowsheet Development," Savannah River National Laboratory, Aiken, SC, SRNL-STI-2010-00523, Rev 0, 2010.

3. D.P. Lambert, B.R. Pickenheim, M.E. Stone, and J.D. Newell, "Glycolic - Formic Acid Flowsheet Final Report for Downselection Decision,” Savannah River National Laboratory, Aiken, SC, SRNLSTI-2010-00523, Rev 0, 2011.

4. D.P. Lambert, M.E. Stone, J.D. Newell, and D.R. Best, "Glycolic-Nitric Acid Flowsheet Demonstration of the DWPF Chemical Processing Cell with Matrix Simulants and Supernate," Savannah River National Laboratory, Aiken, SC, SRNL-STI-2012-00018, Rev 0, 2012.

5. D.P. Lambert, J.R. Zamecnik, and D.R. Best, "Fy13 Glycolic-Nitric Acid Flowsheet Demonstrations of the DWPF Chemical Process Cell with Simulants," Savannah River National Laboratory, Aiken, SC, SRNL-STI-2013-00343, Rev 0, 2014.

6. T.L. Fellinger, "Phase II - Nitric-Glycolic Acid Testing," Savannah River Remediation, Aiken, SC, HLW-DWPF-TTR-2013-0003, 2012.

7. D.P. Lambert, "Task Technical and Quality Assurance Plan for Phase II CPC Testing for NitricGlycolic Flowsheet Development,” Savannah River National Laboratory, Aiken, SC, SRNL-RP-20120076, 2012.

8. D.C. Koopman, "Preparation, Characterization, and Preliminary Testing of a Simulant for the Hydrogen and Rheology Modifiers Program,” Savannah River National Laboratory, Aiken, SC, SRNL-PSE-2007-00191, 2007.

9. D.C. Koopman and J.R. Zamecnik, "DWPF Simulant CPC Studies for SB8," Aiken, SC, Savannah River National Laboratory, SRNL-STI-2013-00106, Rev. 0, 2013.

10. D.C. Koopman, D.R. Best, and B.R. Pickenheim, "SRAT Chemistry and Acid Consumption During Simulated DWPF Melter Feed Preparation,” Savannah River National Laboratory, Aiken, SC, WSRCSTI-2008-00131, 2008.

11. J.R. Zamecnik and T.B. Edwards, "DWPF Nitric-Glycolic Flowsheet Chemical Process Cell Chemistry: Part 1,” Savannah River National Laboratory, Aiken, SC, SRNL-STI-2015-00681, Rev 0, 2016.

12. C.M. Jantzen, J.R. Zamecnik, D.C. Koopman, C.C. Herman, and J.B. Pickett, "Electron Equivalents Model for Controlling Reduction-Oxidation (REDOX) Equilibrium During High Level Waste (HLW) Melting,” Savannah River Technology Center, Aiken, SC, WSRC-TR-2003-00126, Rev. 0, 2003.

13. M.E. Stone, "Laboratory Scale Chemical Process Cell Simulations," Savannah River National Laboratory, Aiken, SC, SRNL Procedure Manual: L29, ITS-0094, Revision: 7, 2012.

14. D.C. Koopman, "Noble Metal Chemistry and Hydrogen Generation During Simulated DWPF Melter Feed Preparation,” Savannah River National Laboratory, Aiken, SC, WSRC-STI-2008-00002, 2008. 
15. M.E. Stone, “Lab-Scale CPC Equipment Set-Up,” Savannah River National Laboratory, Aiken, SC, SRNL-L3100-2011-00127, Rev 2, 2012.

16. T.J. Steeper, “CST Mixing and Sampling Study Tank Weldment and Details," Savannah River National Laboratory, Aiken, SC, EES-22729-PV-005, Rev A, 1999.

17. T.J. Steeper, "CST Mixing and Sampling Study Tank Coil Weldment and Details," Savannah River National Laboratory, Aiken, SC, EES-22729-MO-002, Rev A, 1999.

18. T.J. Steeper, "CST Mixing and Sampling Study Agitator Details," Savannah River National Laboratory, Aiken, SC, EES-22729-R4-003, Rev A, 1999.

19. D.C. Koopman, "Rheology Protocols for DWPF Samples," Savannah River National Laboratory, Aiken, SC, WSRC-RP-2004-00470, 2004.

20. T.L. White, D.P. Lambert, J.R. Zamecnik, and W.T. Riley, "Ion Chromatography (IC) Analysis of Glycolate in Simulated Waste,” Savannah River National Laboratory, Aiken, SC, SRNL-STI-201500049, Rev. 0, 2015.

21. D.P. Lambert and D.C. Koopman, “Glycolic-Formic Acid Flowsheet Sludge Matrix Study,” Savannah River National Laboratory, Aiken, SC, SRNL-STI-2011-00275, 2011.

22. D.T. Wasan and A.P. Nikolov, "Progress Report and Technical Assistance to Support Antifoam Development,” Illinois Institute of Technology, Chicago, IL, Subcontract \# AC70087N, 2011.

23. D.P. Lambert, J.R. Zamecnik, J.D. Newell, and M. Williams, “Antifoam Degradation Testing," Savannah River National Laboratory, Aiken, SC, SRNL-STI-2015-00352, Revision 0, 2015.

24. R.J. Meier, "Mercury Mass Balance on the Defense Waste Processing Facility Chemical Process Cell," Savannah River Remediation, Aiken, SC, SRR-WSE-2014-00068, Revision 0, 2014.

25. D.P. Lambert, J.M. Pareizs, and C.J. Coleman, “Analysis of DWPF CPC Mercury Samples,” Savannah River National Laboratory, Aiken, SC, SRNL-STI-2014-00583, Rev. 0, 2015.

26. "Metrodata Gmbh Gum Workbench: User Manual for Version 1.2, 2.3, and 2.4,” Weil am Rhein, Germany, 2009.

27. J.T. Carter, D.P. Lambert, and A.S. Choi, "Revised Basis and Calculation Methods for the DWPF Ammonia Scrubbers,” Savannah River Technology Center, Aiken, SC, WSRC-TR-92-296, 1992.

28. D.P. Lambert, “Ammonia Scrubber Testing During IDMS SRAT and SME Processing,” Savannah River Technology Center, Aiken, SC, WSRC-TR-94-8000, Rev 1, 1995.

29. C.A. Nash, M.E. Stone, and M.S. Hay, “Analyses and Comparison of Bulk and Coil Surface Samples from the DWPF Slurry Mix Evaporator,” Savannah River National Laboratory, Aiken, SC, SRNLSTI-2011-00623, 2012.

30. J.R. Zamecnik and M.E. Stone, "SME Coil Heat Transfer Preliminary Tests," Savannah River National Laboratory, Aiken, SC, SRNL-L3100-2010-00239, 2012. 


\section{Appendix A GN71 and GN72 SRAT/SME Cycles}

In many of the tables in the report, the GN71 and GN72 data was excluded. This data is presented in Appendix A or can be found in the electronic lab notebook. The SRAT and SME cycle data are discussed below. Chemical and physical data from process samples will be presented first followed by offgas data. Experiments are identified by their run number followed by the acid stoichiometry. For example, the first 4-L experiment is GN71-125 which identifies it as Glycolic/Nitric run 71 at $125 \%$ acid stoichiometry.

The amounts of sludge simulant, nitric acid, and glycolic acid added to each experiment are summarized in Table A-1. The amount of simulant was consistent over the six runs, while the quantity of acids added were adjusted to target an acceptable REDOX ratio.

Table A-1 -- Amount of simulant and acid used for GN71 and GN72 4-L testing

\begin{tabular}{||l|c|c||}
\hline & GN71-125 & GN72-100 \\
\hline Sludge Simulant (g) & 3461 & 3461 \\
\hline Nitric Acid (g) & 288.4 & 247.0 \\
\hline Nitric Acid (mol) & 2.237 & 1.905 \\
\hline Nitric Addition Rate (mL/min) & 2.357 & 2.357 \\
\hline DWPF eq. rate (gpm) & 4.70 & 4.70 \\
\hline Glycolic Acid (g) & 289.5 & 219.6 \\
\hline Glycolic Acid (mol) & 2.733 & 2.071 \\
\hline Glycolic Addition Rate (mL/min) & 1.980 & 1.980 \\
\hline DWPF eq. rate (gpm) & 3.94 & 3.94 \\
\hline Glycolic to total acid (\%) & 54.99 & 52.09 \\
\hline Total mol acid added & 4.97 & 3.976 \\
\hline Acid required/L sludge & 1.637 & 1.309 \\
\hline \hline
\end{tabular}

\section{4-L SRAT Product Results}

Calcined elemental results for the SRAT product slurries are presented in Table A-2. SRAT product compositions for all six experiments were consistent. Supernate cation concentrations are summarized in Table A-3 and solubility data in Table A-4. As expected, higher acid concentrations resulted in a higher degree of metal solubility. 
Table A-2: Calcined Elements of 4-L GN71 to GN72 SRAT Products, wt\%

\begin{tabular}{|c|c|c|}
\hline & GN71-125 & GN72-100 \\
\hline $\mathrm{Al}$ & 10.21 & 11.12 \\
\hline $\mathrm{Ba}$ & 0.15 & 0.15 \\
\hline $\mathrm{Ca}$ & 1.60 & 1.62 \\
\hline $\mathrm{Cr}$ & 0.09 & 0.09 \\
\hline $\mathrm{Cu}$ & 0.06 & 0.10 \\
\hline $\mathrm{Fe}$ & 24.03 & 21.46 \\
\hline $\mathrm{K}$ & 0.16 & 0.18 \\
\hline $\mathrm{Mg}$ & 0.30 & 0.30 \\
\hline $\mathrm{Mn}$ & 7.40 & 7.74 \\
\hline $\mathrm{Na}$ & 17.87 & 16.99 \\
\hline $\mathrm{Ni}$ & 2.30 & 2.34 \\
\hline $\mathrm{P}$ & $<0.100$ & $<0.100$ \\
\hline $\mathrm{Pd}$ & $<0.100$ & $<0.100$ \\
\hline $\mathrm{S}$ & 0.38 & 0.39 \\
\hline $\mathrm{Si}$ & 1.58 & 1.75 \\
\hline $\mathrm{Sn}$ & $<0.100$ & $<0.100$ \\
\hline $\mathrm{Ti}$ & $<0.100$ & $<0.100$ \\
\hline $\mathrm{Zn}$ & $<0.100$ & $<0.100$ \\
\hline $\mathrm{Zr}$ & 0.23 & 0.18 \\
\hline
\end{tabular}

Table A-3: 4-L GN71 to GN72 4L SRAT Product Supernate Cation Concentration, mg/L

\begin{tabular}{|c|c|c|}
\hline & GN71-125 & GN72-100 \\
\hline $\mathrm{Al}$ & 1334 & 187 \\
\hline $\mathrm{B}$ & 0.10 & 0.10 \\
\hline $\mathrm{Ba}$ & 3.35 & 0.58 \\
\hline $\mathrm{Ca}$ & 2591 & 1567 \\
\hline $\mathrm{Cr}$ & 5.83 & 0.50 \\
\hline $\mathrm{Cu}$ & 49.7 & 2.3 \\
\hline $\mathrm{Fe}$ & 4415 & 19.7 \\
\hline $\mathrm{K}$ & 344 & 520 \\
\hline $\mathrm{Mg}$ & 424 & 485 \\
\hline $\mathrm{Mn}$ & 11314 & 11074 \\
\hline $\mathrm{Na}$ & 30102 & 35500 \\
\hline $\mathrm{Ni}$ & 2828 & 49.1 \\
\hline $\mathrm{P}$ & 20.4 & 10.0 \\
\hline $\mathrm{Pd}$ & 1.00 & 1.00 \\
\hline $\mathrm{Rh}$ & 40.2 & 12.3 \\
\hline $\mathrm{Ru}$ & 174 & 69 \\
\hline $\mathrm{S}$ & 764 & 865 \\
\hline $\mathrm{Si}$ & 277 & 47.1 \\
\hline $\mathrm{Sn}$ & 7.91 & 6.85 \\
\hline $\mathrm{Ti}$ & 5.68 & 0.10 \\
\hline $\mathrm{Zn}$ & 36.3 & 0.10 \\
\hline $\mathrm{Zr}$ & 1.00 & 1.00 \\
\hline
\end{tabular}


Table A-4. \% Solubility of Cations in GN71 to GN72 4L SRAT Products

\begin{tabular}{|c|c|c|}
\hline & GN71-125 & GN72-100 \\
\hline $\mathrm{Al}$ & 3.82 & 0.88 \\
\hline $\mathrm{Ca}$ & 106 & 54.9 \\
\hline $\mathrm{Cr}$ & 3.113 & 0.15 \\
\hline $\mathrm{Cu}$ & 23.562 & 0.55 \\
\hline $\mathrm{Fe}$ & 10.170 & 0.05 \\
\hline $\mathrm{K}$ & 71.818 & 84.13 \\
\hline $\mathrm{Li}$ & 2.025 & 0.01 \\
\hline $\mathrm{Mg}$ & 80.269 & 84.15 \\
\hline $\mathrm{Mn}$ & 77.453 & 66.71 \\
\hline $\mathrm{Na}$ & 61.473 & 67.62 \\
\hline $\mathrm{Ni}$ & 80.614 & 0.78 \\
\hline $\mathrm{P}$ & 4.001 & 0.00 \\
\hline $\mathrm{Pd}$ & 0.182 & 0.00 \\
\hline $\mathrm{S}$ & 127.19 & 150.41 \\
\hline $\mathrm{Si}$ & 0.257 & 0.05 \\
\hline $\mathrm{Sn}$ & 1.530 & 0.00 \\
\hline $\mathrm{Ti}$ & 1.123 & 0.00 \\
\hline $\mathrm{Zn}$ & 7.575 & 0.00 \\
\hline $\mathrm{Zr}$ & 0.182 & 0.00 \\
\hline
\end{tabular}

SRAT product slurry and supernate results are summarized in Table A-5 and Table A-6. The total solids target for all experiments was $27.0 \mathrm{wt} \%$.

Table A-5: GN71-72 4-L SRAT Product Solids, Density, and pH

\begin{tabular}{||l|c|c||}
\hline & GN71-125 & GN72-100 \\
\hline Total Solids, wt \% & 25.95 & 28.40 \\
\hline Insoluble Solids, wt \% & 9.80 & 13.20 \\
\hline Calcined Solids, wt \% & 13.28 & 16.32 \\
\hline Soluble Solids, wt \% & 16.16 & 15.20 \\
\hline $\mathrm{pH}$ & 3.79 & 7.15 \\
\hline Slurry Density, g/mL & 1.19 & 1.12 \\
\hline Supernate Density, g/mL & 1.13 & 1.13 \\
\hline
\end{tabular}

Table A-6: GN71-72 4-L SRAT Product Slurry Anions, mg/kg

\begin{tabular}{|l|c|c|}
\hline Anion & GN71-125 & GN72-100 \\
\hline $\mathrm{F}^{-}$ & $<500$ & $<500$ \\
\hline $\mathrm{Cl}^{-}$ & $<500$ & 530 \\
\hline $\mathrm{NO}_{2}{ }^{-}$ & $<500$ & $<500$ \\
\hline $\mathrm{NO}_{3}{ }^{-}$ & 61,450 & 58,500 \\
\hline $\mathrm{C}_{2} \mathrm{H}_{3} \mathrm{O}_{3}{ }^{-}$ & 57,000 & 41,100 \\
\hline $\mathrm{SO}_{4}{ }^{2-}$ & 1,470 & 1,640 \\
\hline $\mathrm{C}_{2} \mathrm{O}_{4}{ }^{2-}$ & 2,360 & 2,640 \\
\hline $\mathrm{HCO}_{2}{ }^{-}$ & 608 & 677 \\
\hline $\mathrm{PO}_{4}{ }^{3-}$ & $<500$ & $<500$ \\
\hline \hline
\end{tabular}




\section{4-L SME Product Results}

Calcined elements for the SME products are reported in Table A-7. A 36 wt\% waste loading was targeted.

Table A-7: Calcined Elements of GN71-72 4-L SME Products, Wt\%

\begin{tabular}{|c|c|c||}
\hline & GN71-125 & GN72-100 \\
\hline $\mathrm{Al}$ & 3.68 & 4.08 \\
\hline $\mathrm{B}$ & 1.36 & 1.55 \\
\hline $\mathrm{Ba}$ & 0.05 & $<0.100$ \\
\hline $\mathrm{Ca}$ & 0.49 & 0.51 \\
\hline $\mathrm{Cr}$ & 0.04 & 0.04 \\
\hline $\mathrm{Cu}$ & 0.04 & 0.04 \\
\hline $\mathrm{Fe}$ & 7.92 & 9.19 \\
\hline $\mathrm{K}$ & 0.10 & 0.11 \\
\hline $\mathrm{Li}$ & 2.37 & 2.38 \\
\hline $\mathrm{Mg}$ & 0.11 & 0.11 \\
\hline $\mathrm{Mn}$ & 2.68 & 2.98 \\
\hline $\mathrm{Na}$ & 10.03 & 10.04 \\
\hline $\mathrm{Ni}$ & 0.66 & 0.75 \\
\hline $\mathrm{P}$ & $<0.100$ & $<0.100$ \\
\hline $\mathrm{Pd}$ & $<0.100$ & $<0.100$ \\
\hline $\mathrm{S}$ & 0.13 & 0.11 \\
\hline $\mathrm{Si}$ & 24.12 & 22.74 \\
\hline $\mathrm{Sn}$ & $<0.100$ & $<0.100$ \\
\hline $\mathrm{Ti}$ & $<0.100$ & $<0.100$ \\
\hline $\mathrm{Zn}$ & $<0.100$ & $<0.100$ \\
\hline $\mathrm{Zr}$ & $<0.100$ & $<0.100$ \\
\hline
\end{tabular}

The SME product solids, $\mathrm{pH}$, and density data are reported in Table A-8. A final total solids concentration of $45 \mathrm{wt} \%$ was targeted for all experiments. SME product anion data are summarized in Table A-9.

Table A-8: GN71-72 4-L SME Product Solids, Density, and pH

\begin{tabular}{||l|c|c||}
\hline & GN71-125 & GN72-100 \\
\hline Total Solids, wt \% & 44.44 & 46.82 \\
\hline Insoluble Solids, wt \% & 30.71 & 32.62 \\
\hline Calcined Solids, wt \% & 33.31 & 36.41 \\
\hline Soluble Solids, wt \% & 13.73 & 14.19 \\
\hline $\mathrm{pH}$ & 3.91 & 7.30 \\
\hline Slurry Density, g/mL & 1.361 & 1.374 \\
\hline Supernate Density, g/mL & 1.141 & 1.137 \\
\hline Waste Loading, wt\% & 36.2 & 35.9 \\
\hline
\end{tabular}


SRNL-STI-2014-00306

Revision 0

Table A-9: GN71-72 4-L SME Product Slurry Anions, mg/kg

\begin{tabular}{|l|c|c||}
\hline Anion & GN71-125 & GN72-100 \\
\hline $\mathrm{F}^{-}$ & $<500$ & $<500$ \\
\hline $\mathrm{Cl}^{-}$ & $<500$ & 555 \\
\hline $\mathrm{NO}_{2}{ }^{-}$ & $<500$ & $<500$ \\
\hline $\mathrm{NO}_{3}{ }^{-}$ & 58,100 & 50,700 \\
\hline $\mathrm{C}_{2} \mathrm{H}_{3} \mathrm{O}_{3}^{-}$ & 52,500 & 39,500 \\
\hline $\mathrm{SO}_{4}{ }^{-2-}$ & 1,350 & 1,580 \\
\hline $\mathrm{C}_{2} \mathrm{O}_{4}{ }^{2-}$ & 2,320 & 3,660 \\
\hline $\mathrm{HCO}_{2}{ }^{-}$ & 501 & 1,090 \\
\hline $\mathrm{PO}_{4}{ }^{--}$ & $<500$ & $<500$ \\
\hline
\end{tabular}

\section{4-L Offgas Gas Chromatograph}

Helium, hydrogen, oxygen, nitrogen, carbon dioxide, nitric oxide, and nitrous oxide were measured throughout the runs using a GC. Carbon dioxide was the first offgas detected Figure A-1. ) followed by nitrous oxide generation (Figure A-2). Carbon dioxide peaked at approximately 40-50 volume percent near the end of nitric acid addition. Offgas data show two additional peaks, one occurring during glycolic acid addition and another just after the initiation of boiling. Oxygen concentration was seen to decrease as carbon dioxide and nitrous oxide were generated (Figure A-3).

No significant concentration of hydrogen was observed during the 4-L testing, with the exception of GN71-125. As a result of the very viscous SRAT product produced during the high acid SRAT cycle, material had collected onto one of the heating rods causing it to foul. Fouling resulted in a rapid increase in rod temperature, and hydrogen was briefly generated (Figure A-4). Hydrogen was not detected after rod replacement. 


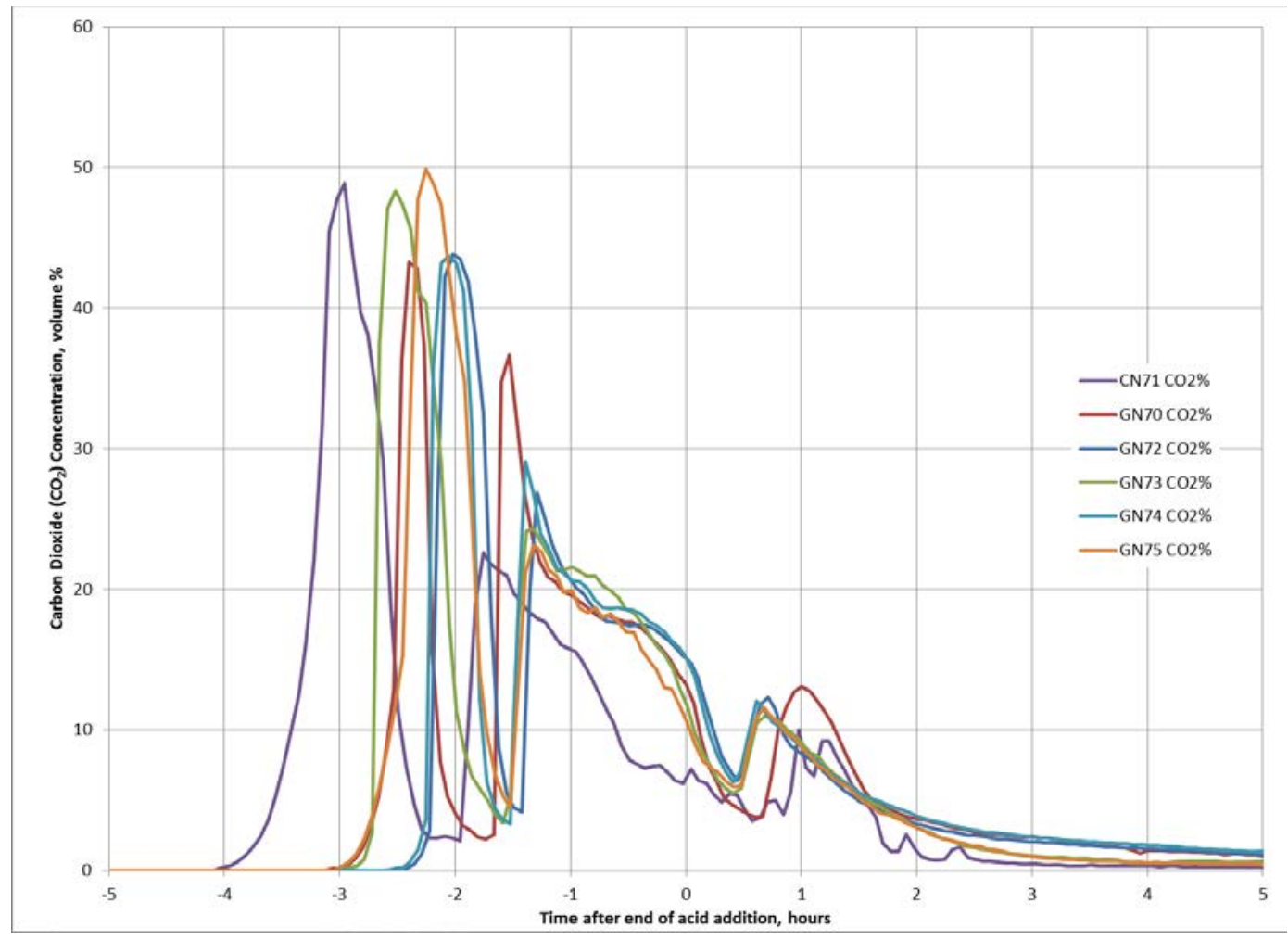

Figure A-1. 4-L GC Measured $\mathrm{CO}_{2}$ Concentration.

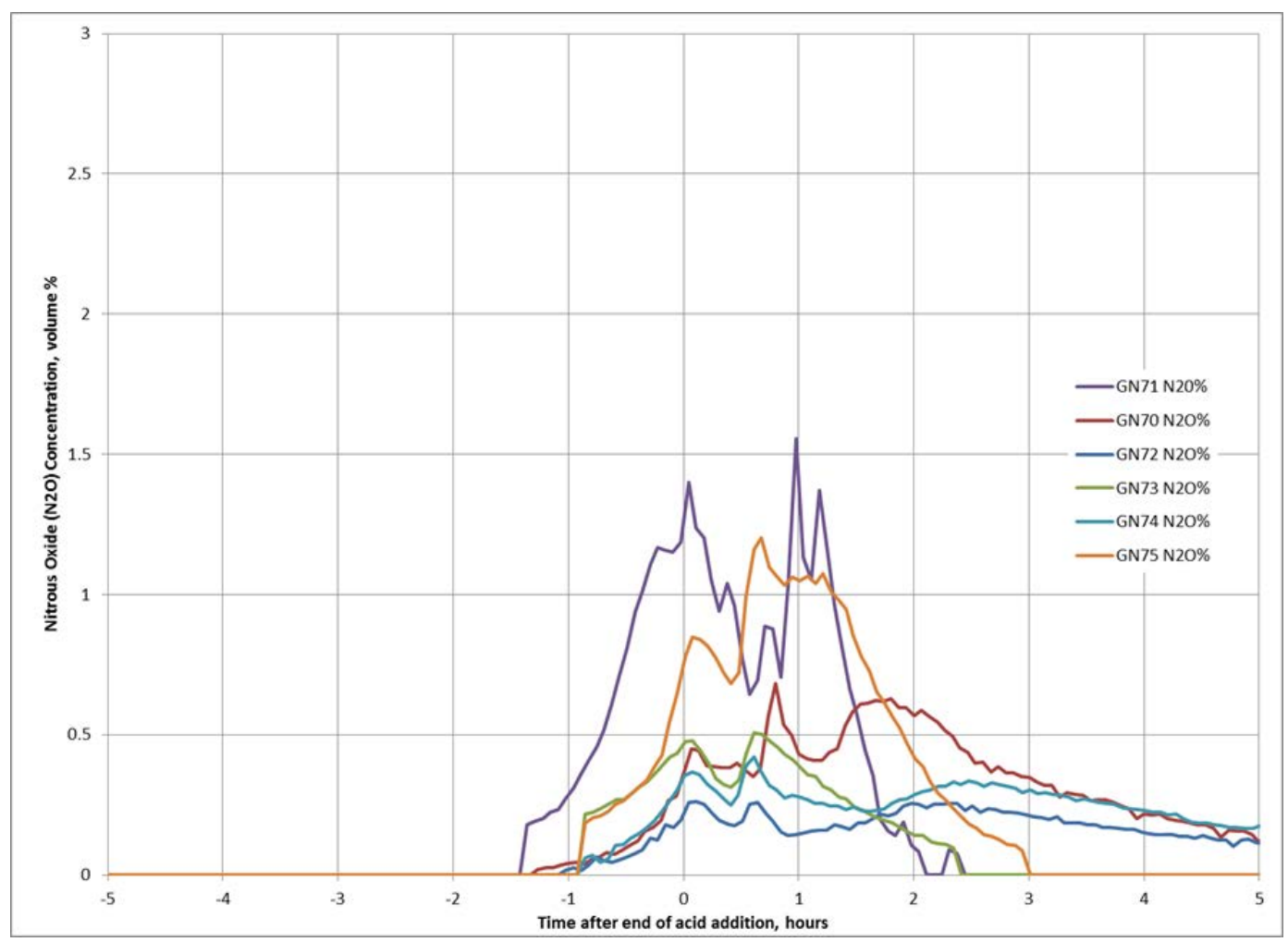

Figure A-2. 4-L GC Measured Nitrous Oxide Concentration. 


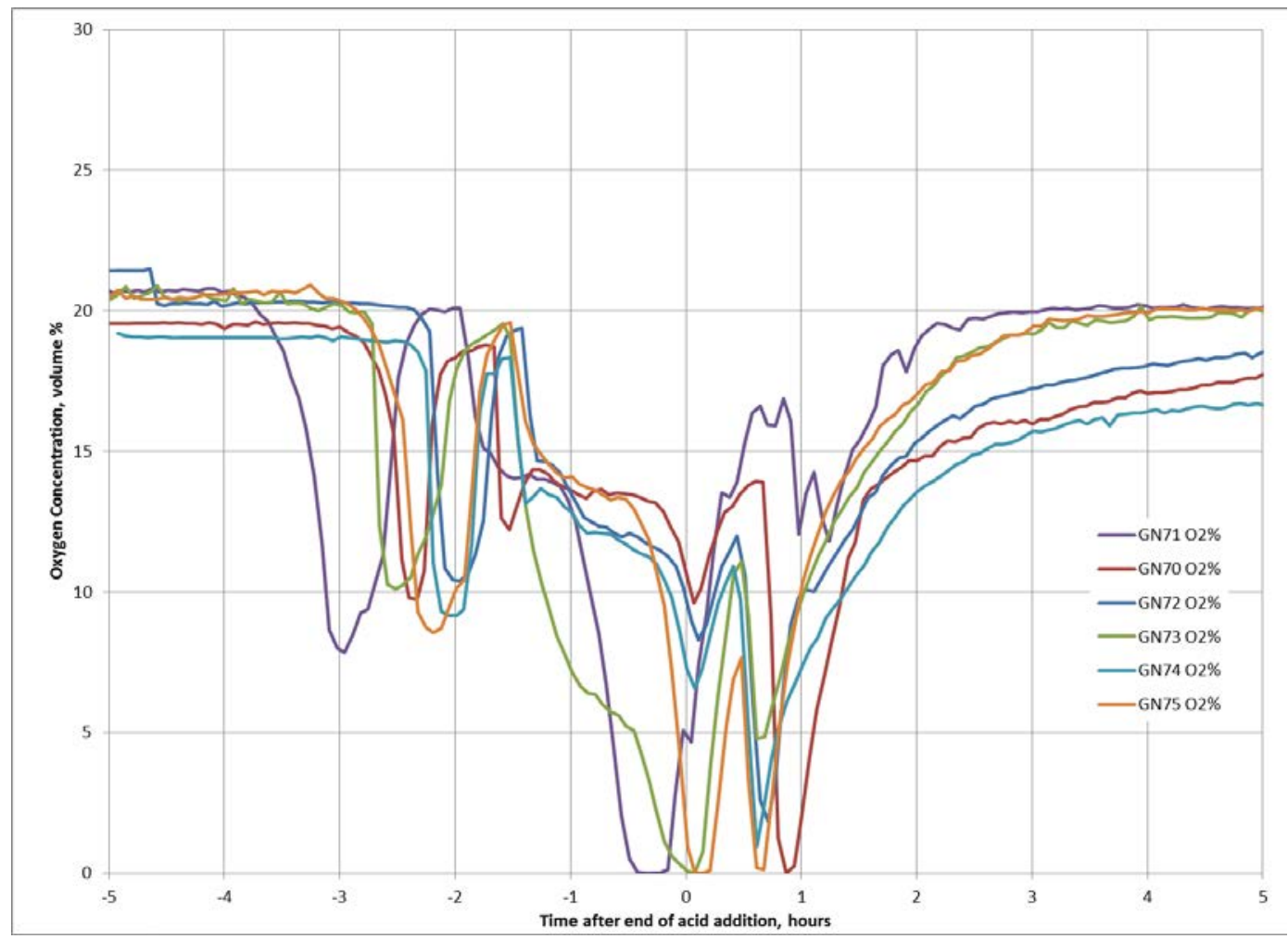

Figure A-3. 4-L GC Measured Oxygen Concentration.

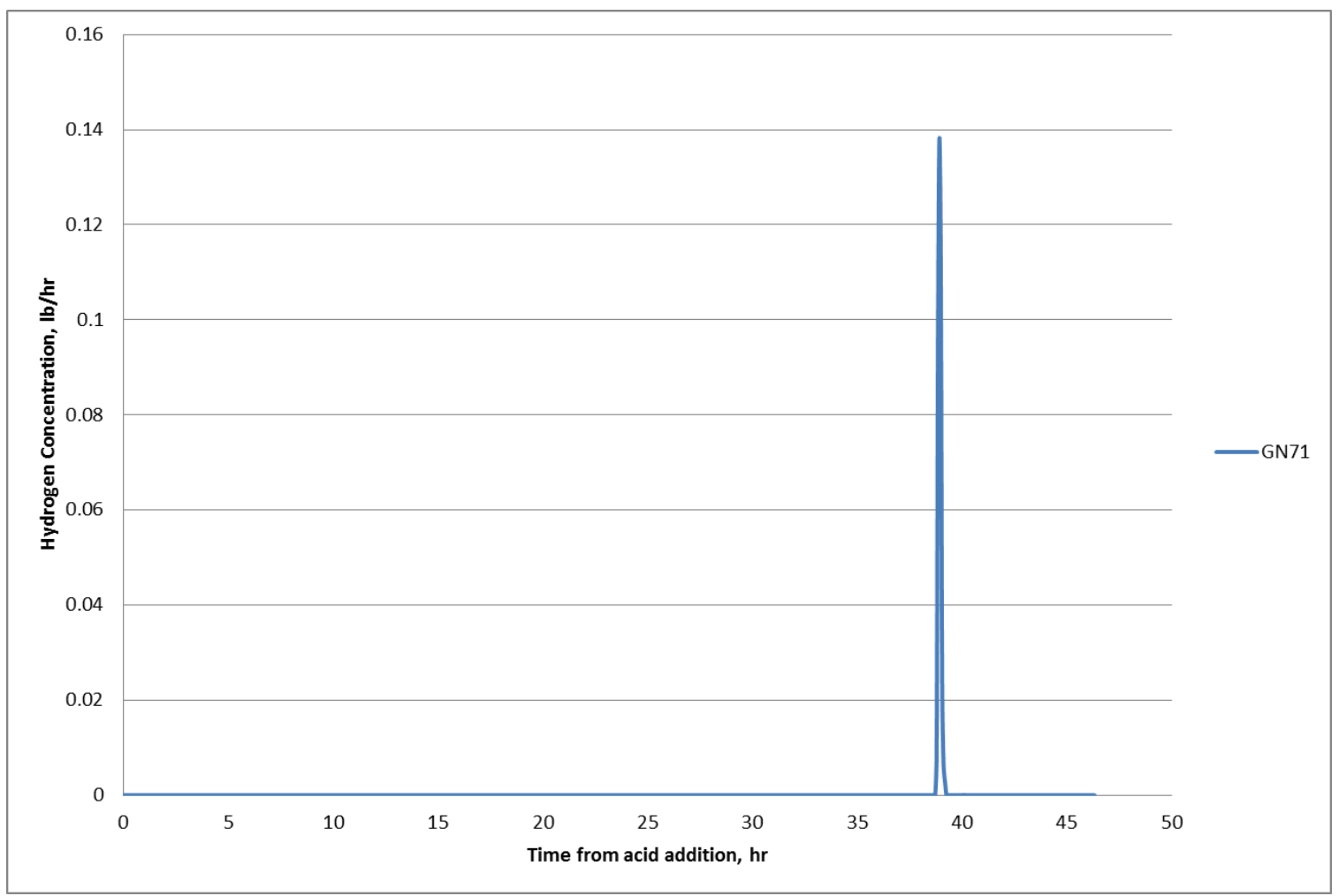

Figure A-4. 4-L GC Measured Hydrogen Generation. 


\section{4-L REDOX}

The REDOX equation was initially used for GN70 and GN71 to target a REDOX value of $0.2 \mathrm{Fe}^{2+} / \Sigma \mathrm{Fe}$. The prediction required glycolic acid to total acid ratio of 0.5831 for GN70 and 0.5499 for GN71. These ratios resulted in a higher REDOX value than expected. For the remaining 4-L experiments, the acid ratios were adjusted until an acceptable REDOX value was obtained. Those ratios were then carried forward into the 22-L and 220-L experiments. REDOX values for the GN71 and GN72 are presented in Table A-2.

Table A-10. GN71 and GN72 4-L REDOX

\begin{tabular}{|l|c|c||}
\hline & GN71-125 & GN72-100 \\
\hline Percent reducing acid & 54.99 & 52.09 \\
\hline REDOX by closed crucible & 0.515 & 0.083 \\
\hline
\end{tabular}

\section{4-L Rheology}

Rheological properties of slurries are known to depend on particle size, insoluble solids content, $\mathrm{pH}$, and ionic strength (molarity of ionic charges from cations and anions). For a given insoluble solids matrix, the major factor for SRAT and SME slurries has historically been the wt\% insoluble solids content. The effect of $\mathrm{pH}$ is not trivial. Flow curves were obtained for the six SRAT product slurries and the six SME product slurries from the flowsheet runs. Measurements were made at $25{ }^{\circ} \mathrm{C}$. Previously established flow curve protocols were used. The SRAT results, fit to the Bingham plastic model, are given in Table A-11.

Table A-11. 4-L GN71 and GN72 SRAT and SME Product Rheology.

\begin{tabular}{||c|c|c|}
\hline & GN71-125 & GN72-100 \\
\hline SRAT Product & & \\
\hline Yield Stress, Pa & 20.70 & 0.298 \\
\hline Consistency, cP & 11.5 & 3.64 \\
\hline & & \\
\hline SME Product & & \\
\hline Yield Stress, Pa & 41.90 & 0.760 \\
\hline Consistency, cP & 40.8 & 19.5 \\
\hline
\end{tabular}


SRNL-STI-2014-00306

Revision 0

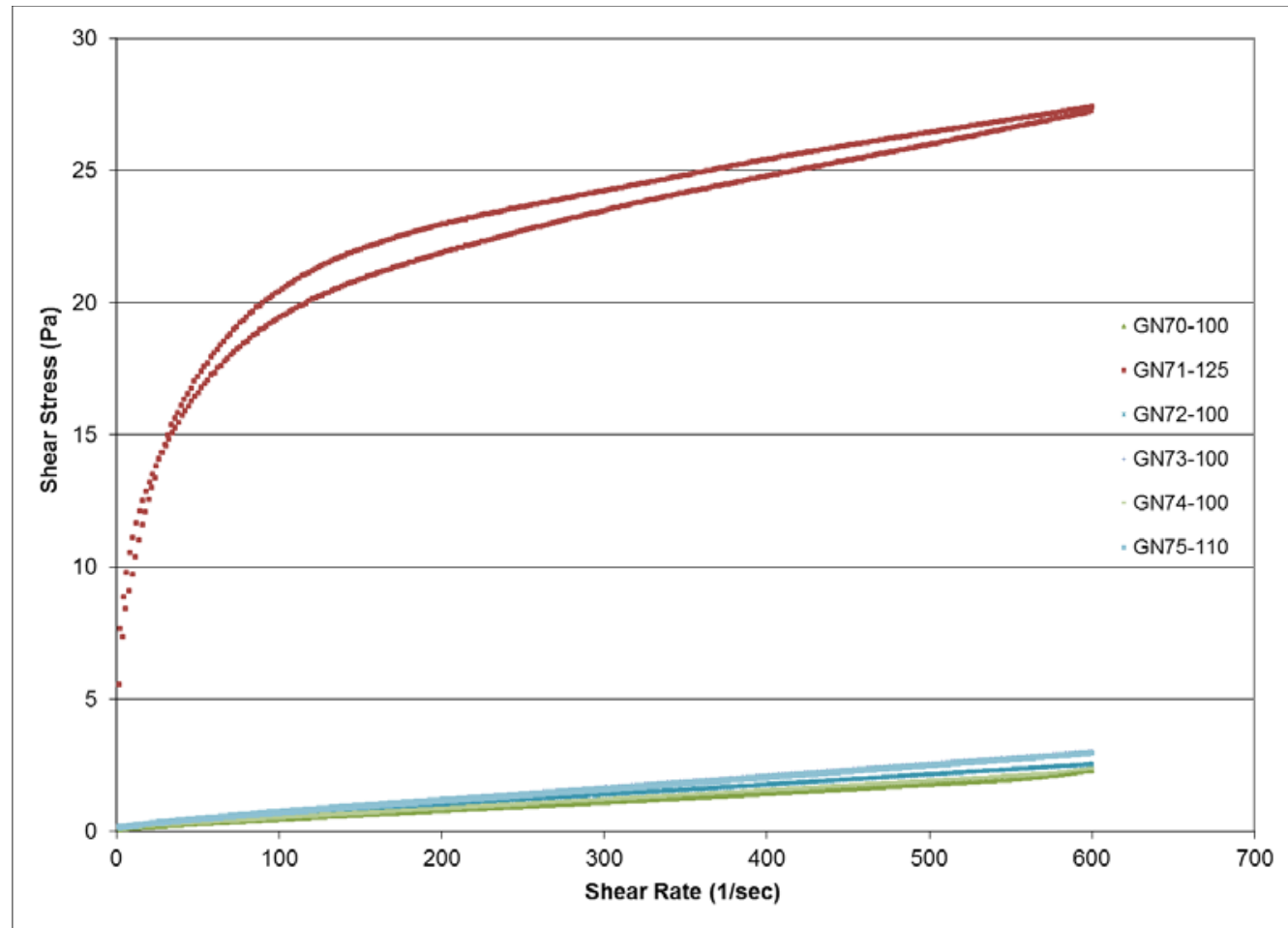

Figure A-5. 4-L SRAT Product Rheology.

SRAT and SME product rheograms (Figure A-5 and Figure A-6) were generally well reproduced in the replicate pairs and showed negligible hysteresis between up and down flow curves. The rheology flow curves were used to calculate the yield stress and consistency of the products for each run and presented in Table A-12. . The results were consistent with previous experiments, in that the SRAT and SME product viscosities are low. This trend is consistent with all of the 4-L SRAT and SME products with the exception of the high acid run, GN71-125. The SRAT and SME product viscosities of GN71-125 were considerably higher. It is postulated that the excess unreacted glycolic acid is forming polymeric chains that result in higher viscosities. 
SRNL-STI-2014-00306

Revision 0

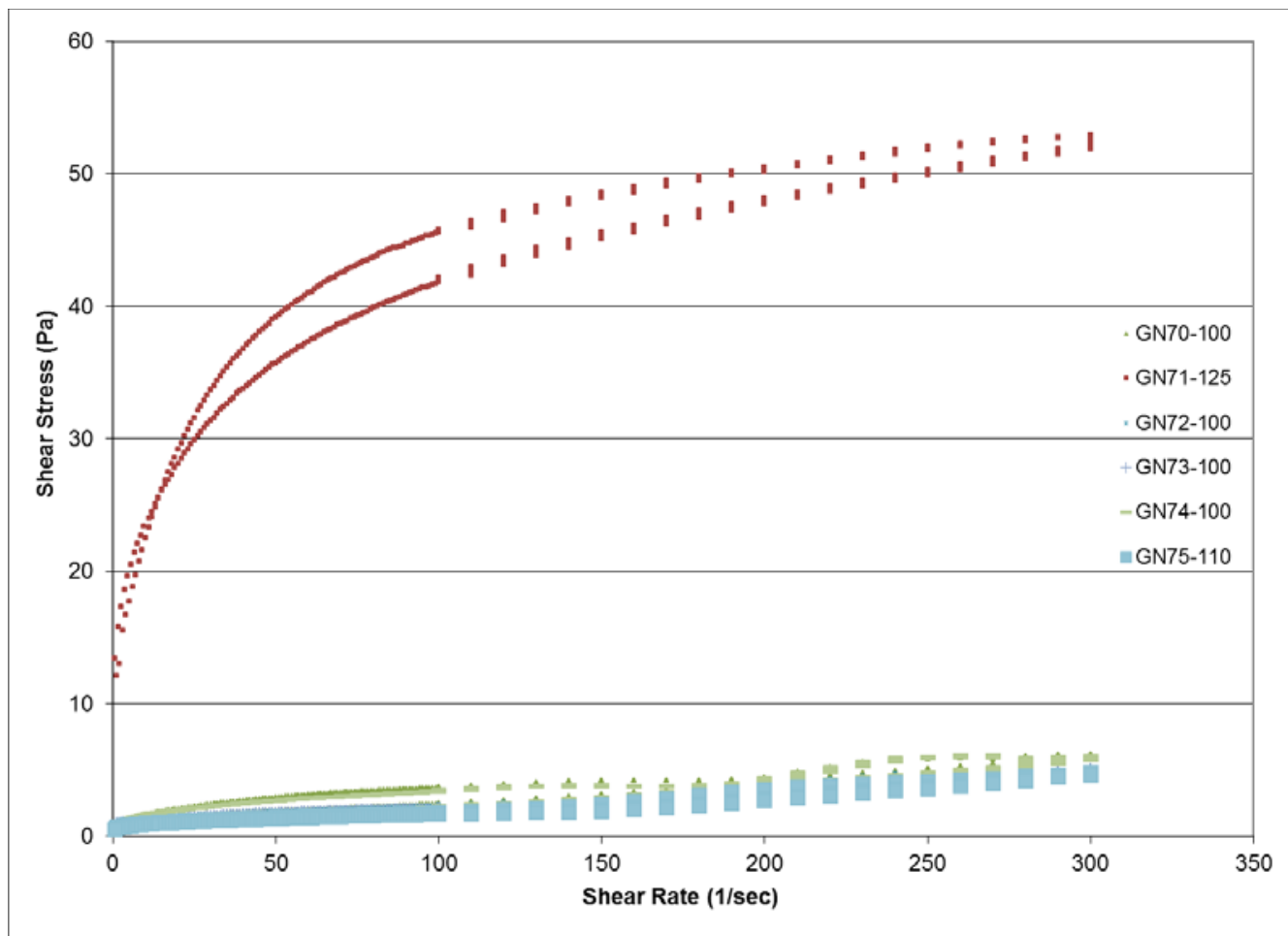

Figure A-6. 4-L SME Product Rheology. 


\section{Appendix B Heat Transfer}

\section{4-L Heat Transfer}

Two heating rods were used for providing heat for processing. The heating rods have built-in thermocouples and measure the amps and volts supplied during heating which allows for the calculation of a heat transfer coefficient, a measure of how efficiently the heat is transferred to the slurry. In previous testing ${ }^{4}$, the rods fouled during processing in a similar manner to the coil fouling that has been seen in DWPF.

The heat transfer coefficients for the SRAT cycles are shown in Figure B-1. The heat transfers for five of the six runs were relatively the same, allowing for minor differences in the heating rods. The heat transfer coefficients for similar glycolic/nitric acid flowsheet experiments were similar: $0.15-0.17 \mathrm{~W} / \mathrm{cm}^{2} /{ }^{\circ} \mathrm{C} .{ }^{5}$ The high acid run (GN71-125) produced a product that was very thick and was difficult to mix. Lack of adequate mixing can result in fouling of the heating rods and a decrease in heat transfer. This can be seen around twenty hours after acid addition. Ultimately, a heating rod was replaced. The heat transfer for the SME cycles is shown in Error! Reference source not found.. Again, heat transfer for the GN75-125 was generally worse and showed larger heat transfer variations upon heat-to-boiling after water additions.

Mixing speeds for the SRAT runs are typically $300 \mathrm{rpm}$. Mixing was increased for the GN71-125 up to $900 \mathrm{rpm}$ in an effort to improve heat transfer.

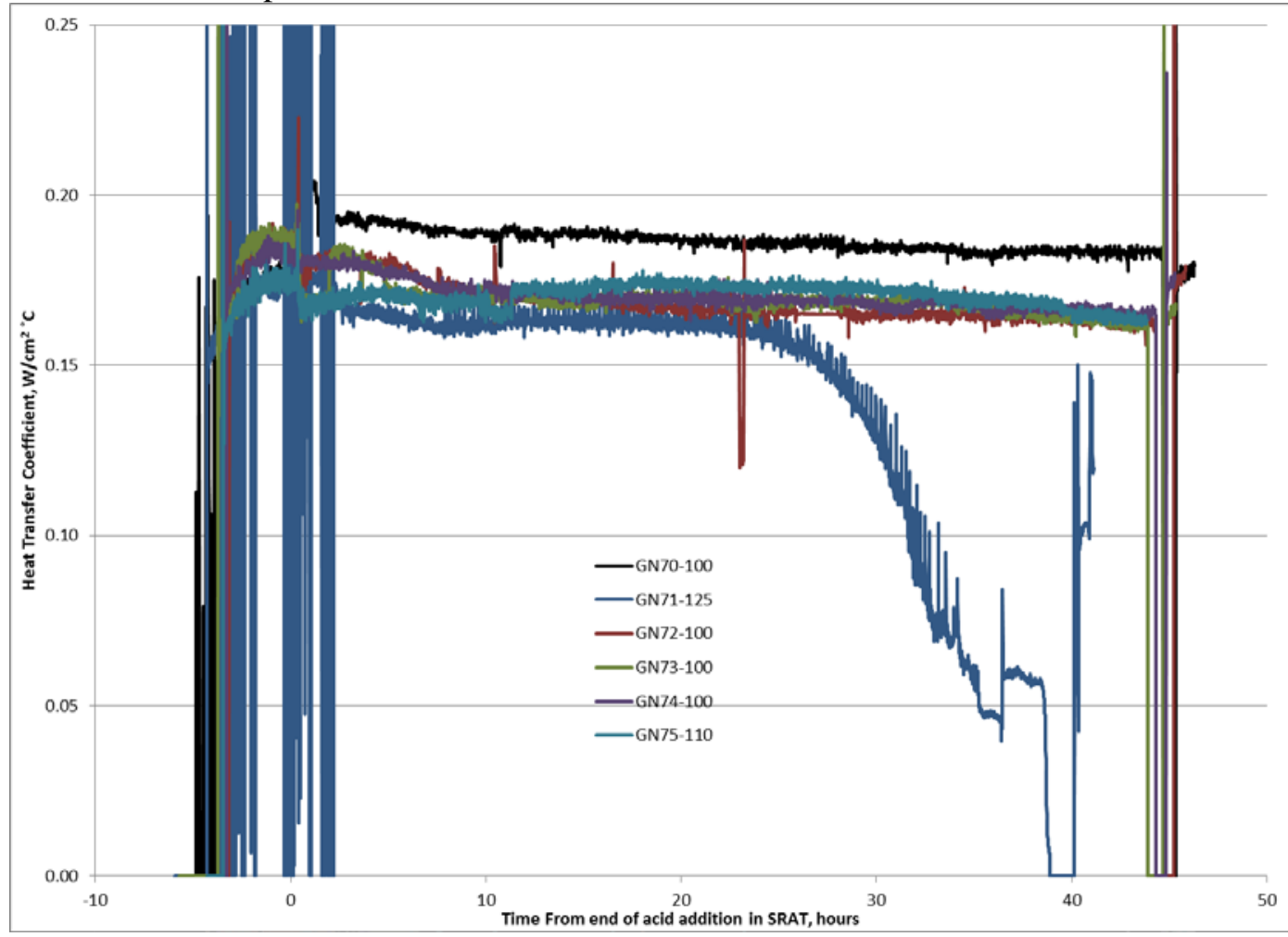

Figure B-1: 4-L SRAT Cycle Heat Transfer Coefficient. 


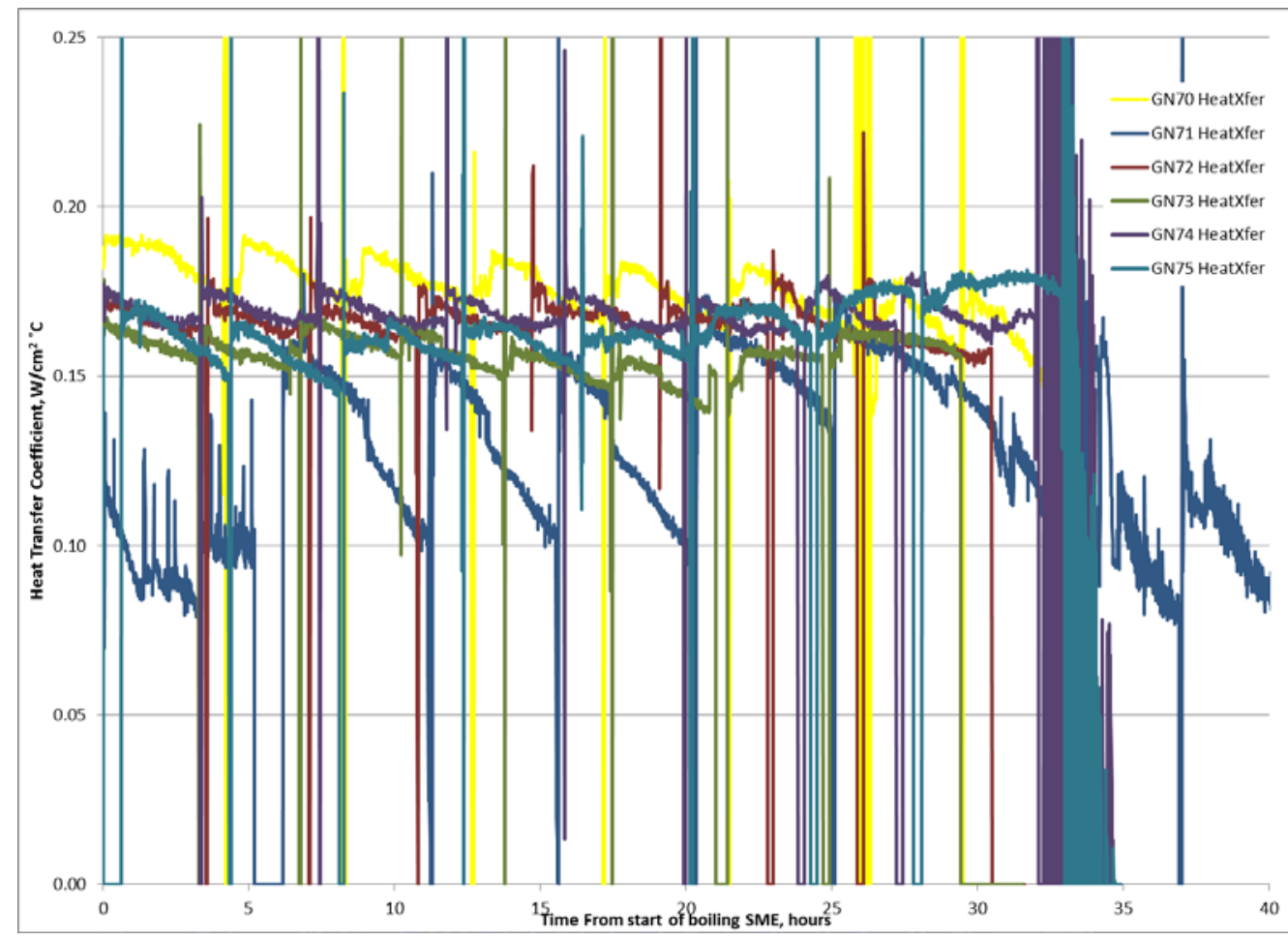

Figure B-2: 4-L SME Cycle Heat Transfer Coefficient.

\section{2-L Heat Transfer}

Four heating rods were used for providing heat for processing. The heating rods have thermocouples and measure the amps and volts supplied during heating which allows for the calculation of a heat transfer coefficient, a measure of how efficiently the heat is transferred to the slurry. The heat transfer coefficients for the SRAT and SME cycles could not be measured. The heating rods in used in the 22-L equipment contain a surface thermocouple, as opposed to the 4- $\mathrm{L}$ thermocouple having a centerline thermocouple. Temperature differential between the heating rod and the process temperature were very small, resulting in very high heat transfer calculation.

\section{0-L Heat Transfer}

GN78-110 and GN79-100 were run in the same vessel and utilized the same steam coil. Process heat was provided to the $220-\mathrm{L}$ vessel using a steam generator and steam coil. The $220-\mathrm{L}$ steam coil design was based upon the DWPF steam coil. The rate at which steam entered the coil was controlled using a $1 / 2$ inch orifice steam valve. Once the steam exited the coil and passed through a steam trap, it would condense to water and be collected and weighed. The mass of the steam condensate was used to calculate the heat transferred into the SRAT and SME products. The average heat transfer coefficients for both 220-L runs were similar to those of the 4-L runs and are reported in Table B-. 
Table B-1. Average Heat Transfer in 220-L SRAT and SME for GN78-GN79

\begin{tabular}{|c|c|c||}
\hline & GN79-100 & GN78-110 \\
\hline SRAT Heat transfer, $\mathrm{W} / \mathrm{cm}^{2}-{ }^{\circ} \mathrm{C}$ & 0.15 & 0.20 \\
\hline SME Heat transfer, $\mathrm{W} / \mathrm{cm}^{2}-{ }^{\circ} \mathrm{C}$ & 0.44 & 0.40 \\
\hline
\end{tabular}

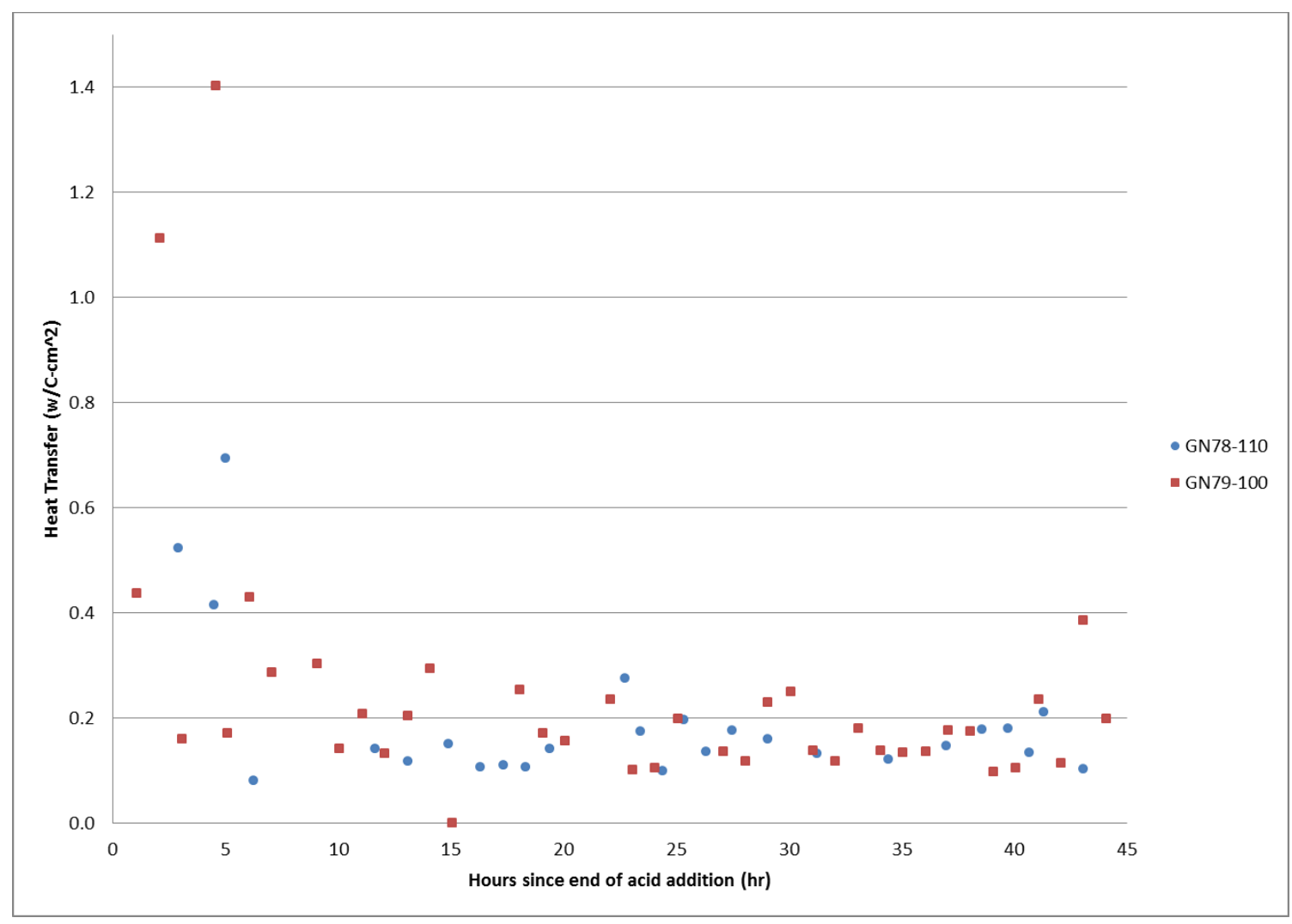

Figure B-3: 220-L SRAT Cycle Heat Transfer Coefficient. 
SRNL-STI-2014-00306

Revision 0

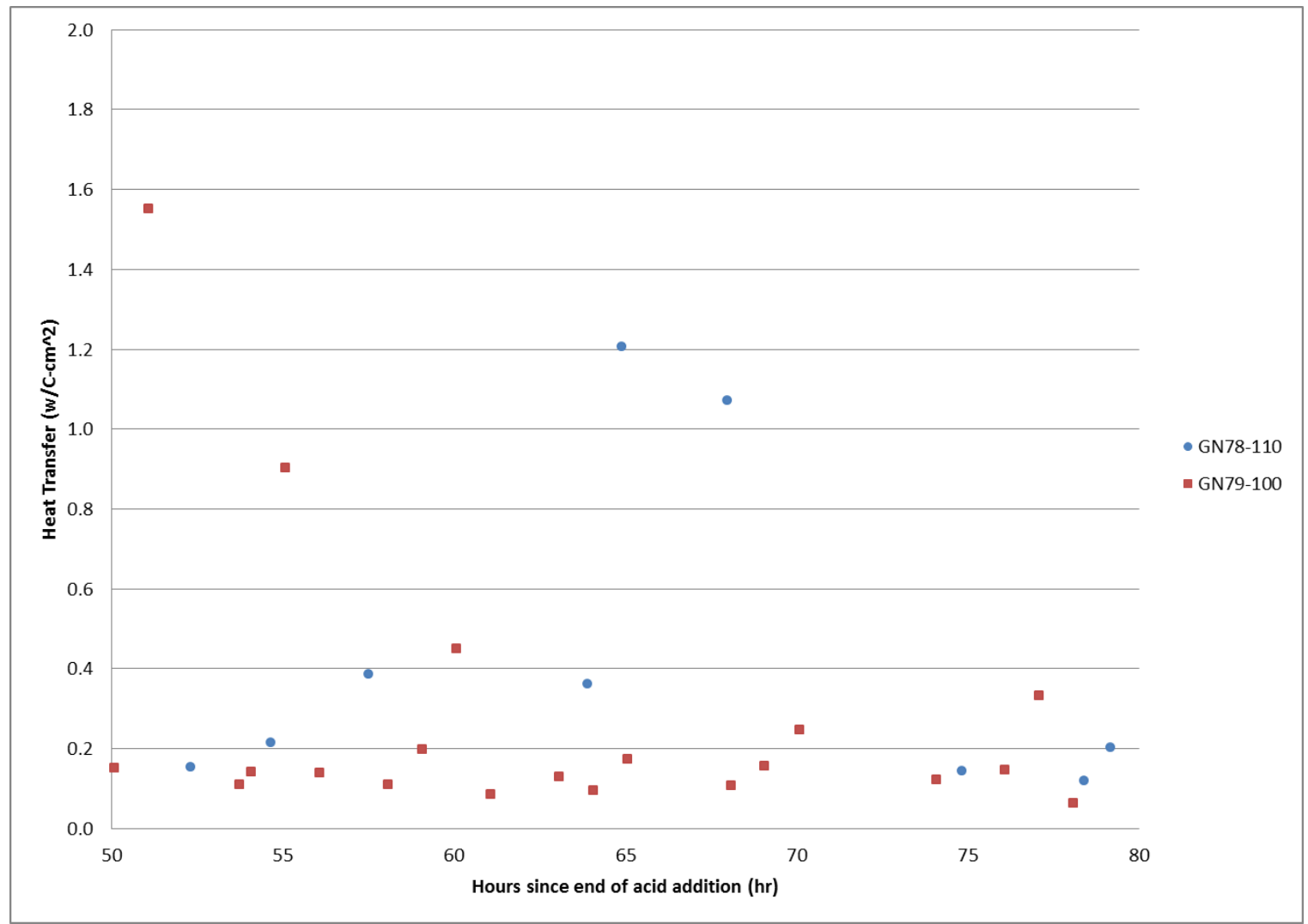

Figure B-4: 220-L SME Cycle Heat Transfer Coefficient.

A major concern during GN78 and GN79 testing was the possibility of fouling the steam coil. Fouling of the DWPF SME tank steam coils has been frequently noted during processing of previous sludge batches, requiring the coil to be removed and cleaned. ${ }^{29}$ Buildup of slurry on the steam coil or heating rod while heating leads to a decrease in heat transfer and can result in fouling. ${ }^{29,30}$ 
Appendix C -- Scaling Calculations

\begin{tabular}{|c|c|c|c|c|c|c|c|c|}
\hline \multirow[t]{2}{*}{ Parameter } & \multicolumn{2}{|c|}{ DWPF } & \multirow[b]{2}{*}{ Value } & \multirow[b]{2}{*}{ Units } & \multicolumn{2}{|c|}{ 220-L } & \multirow[b]{2}{*}{ Value } & \multirow[b]{2}{*}{ Units } \\
\hline & Value & Units & & & Value & Units & & \\
\hline Linear Scale & 1 & & 6 & & 11.01 & & 20.9 & \\
\hline Area Scale & 1 & & 36 & & 121.3 & & 435.4 & \\
\hline Volume Scale & 1 & & 216 & & 1336 & & 9084 & \\
\hline Batch Size & 6000 & gal & 105.14 & liters & 17 & liters & 2.5 & liters \\
\hline Heel & 1500 & gal & 26.28 & liters & 4.25 & liters & 0.63 & liters \\
\hline Flush Water & 1500 & gal & 26.28 & liters & 4.25 & liters & 0.63 & liters \\
\hline Air Purge & 90 & scfm & 11.80 & LPM & 1.91 & LPM & 0.28 & LPM \\
\hline Helium & 0 & scfm & 58.99 & $\mathrm{sccm}$ & 9.54 & $\mathrm{sccm}$ & 1.40 & $\mathrm{sccm}$ \\
\hline $\begin{array}{ll}\text { Acid } & \text { Addition } \\
\text { Rate } & \\
\end{array}$ & 2 & GPM & 35.05 & $\mathrm{ml} / \mathrm{min}$ & 5.67 & $\mathrm{ml} / \mathrm{min}$ & 0.83 & $\mathrm{ml} / \mathrm{min}$ \\
\hline Steam Rate & 5000 & $\mathrm{lb} / \mathrm{hr}$ & 175.36 & $\mathrm{~g} / \mathrm{min}$ & 28.35 & $\mathrm{~g} / \mathrm{min}$ & 4.17 & $\mathrm{~g} / \mathrm{min}$ \\
\hline Boiling Flux & 44.21 & $\mathrm{lb} / \mathrm{hr} / \mathrm{ft}^{2}$ & 7.37 & $\mathrm{lb} / \mathrm{hr} / \mathrm{ft}^{2}$ & 5.08 & $\mathrm{lb} / \mathrm{hr} / \mathrm{ft}^{2}$ & 2.90 & $\mathrm{lb} / \mathrm{hr} / \mathrm{ft}^{2}$ \\
\hline $\begin{array}{l}\text { MWWT } \\
\text { Diameter }\end{array}$ & 3 & $\mathrm{ft}$ & 6.00 & in & 3.27 & in & 1.73 & in \\
\hline MWWT Length & 4.3 & $\mathrm{ft}$ & 8.67 & in & 4.72 & in & 2.49 & in \\
\hline $\begin{array}{l}\text { MWWT } \\
\text { Overflow } \\
\text { Volume }\end{array}$ & 90 & gal & 1.58 & liters & 0.255 & liters & 0.038 & liters \\
\hline $\begin{array}{l}\text { SRAT condenser } \\
\text { Diameter }\end{array}$ & 2 & $\mathrm{ft}$ & 4.00 & in & 2.18 & in & 1.15 & in \\
\hline $\begin{array}{l}\text { SRAT Condenser } \\
\text { Length }\end{array}$ & 7.33 & $\mathrm{ft}$ & 14.66 & in & 7.99 & in & 4.22 & in \\
\hline Number of Tubes & 313 & & 13.04 & tubes & 12.00 & tubes & 7.00 & tubes \\
\hline Tube Diameter & 0.75 & in & 0.50 & in & 0.25 & in & 0.25 & in \\
\hline Tube Volume & 7375 & $\mathrm{in}^{3}$ & 24 & $\mathrm{in}^{3}$ & 4.70 & $\mathrm{in}^{3}$ & 1.45 & in $^{3}$ \\
\hline Tube Volume & 120.8 & liters & 0.39 & liters & 0.08 & liters & 0.024 & liters \\
\hline $\begin{array}{l}\text { SRAT Condenser } \\
\text { Heat Xfer Area }\end{array}$ & 450.5 & $\mathrm{ft}^{2}$ & 300 & in $^{2}$ & 48.6 & in $^{2}$ & 7.14 & in $^{2}$ \\
\hline $\begin{array}{l}\text { Ammonia } \\
\text { Scrubber } \\
\text { Diameter }\end{array}$ & 18.8 & in & & & 1.7 & in & 0.9 & in \\
\hline $\begin{array}{l}\text { Ammonia } \\
\text { Scrubber Length }\end{array}$ & 111 & in & & & 10.1 & in & 5.3 & in \\
\hline $\begin{array}{l}\text { Ammonia } \\
\text { Scrubber Area }\end{array}$ & 277.6 & in $^{2}$ & & & 2.3 & in2 & 0.6 & in2 \\
\hline
\end{tabular}


SRNL-STI-2014-00306

Revision 0

\begin{tabular}{|c|c|c|c|c|c|c|c|c|}
\hline \multirow[t]{2}{*}{ Parameter } & \multicolumn{2}{|c|}{ DWPF } & \multirow[b]{2}{*}{ Value } & \multirow[b]{2}{*}{ Units } & \multicolumn{2}{|c|}{$220-\mathrm{L}$} & \multirow[b]{2}{*}{ Value } & \multirow[b]{2}{*}{ Units } \\
\hline & Value & Units & & & Value & Units & & \\
\hline $\begin{array}{l}\text { Ammonia } \\
\text { Scrubber } \\
\text { Flowrate } \\
\end{array}$ & 20 & GPM & 2.10 & $\mathrm{~L} / \mathrm{min}$ & 624.09 & $\mathrm{ml} / \mathrm{min}$ & 173.88 & $\mathrm{ml} / \mathrm{min}$ \\
\hline $\begin{array}{l}\text { FAVC condenser } \\
\text { Diameter }\end{array}$ & 2 & $\mathrm{ft}$ & 4.00 & in & 2.18 & in & 1.15 & in \\
\hline $\begin{array}{l}\text { FAVC } \\
\text { Condenser } \\
\text { Length } \\
\end{array}$ & 5 & $\mathrm{ft}$ & 10.00 & in & 5.45 & in & 2.88 & in \\
\hline $\begin{array}{ll}\text { FAVC } & \\
\text { Condenser } & \text { Heat } \\
\text { Xfer Area } & \\
\end{array}$ & 233 & $\mathrm{ft}^{2}$ & 930.225 & in $^{2}$ & 276.086 & in $^{2}$ & 76.92 & in $^{2}$ \\
\hline $\begin{array}{ll}\text { Offgas } & \text { Pipe } \\
\text { Diameter } & \\
\end{array}$ & 6 & in & & & & & & \\
\hline & & & & & Actual & & Actual & \\
\hline $\begin{array}{l}\text { Impeller } \\
\text { Diameter }\end{array}$ & 3 & $\mathrm{ft}$ & 4.25 & in & 4 & in & 3 & in \\
\hline Vessel Diameter & 12 & $\mathrm{ft}$ & 24 & in & 11.6 & in & 5.9 & in \\
\hline $\mathrm{L} / \mathrm{D}$ & 0.25 & & 0.25 & & 0.34 & & 0.51 & \\
\hline Vessel Height & 16.4 & $\mathrm{ft}$ & & in & & in & & in \\
\hline Liquid Height & 8.2 & $\mathrm{ft}$ & & in & & in & & in \\
\hline Steam Coil Area & 343.3 & $\mathrm{ft}^{2}$ & & $\mathrm{ft}^{2}$ & & & & \\
\hline Volume - low & 6000 & gallons & & gallons & & rods & 2 & rods \\
\hline Volume - high & 10000 & gallons & & gallons & & in & 0.5 & in \\
\hline & & & & & & in & 4 & in \\
\hline Steam Coil Area & 49435 & in $^{2}$ & & in $^{2}$ & & in2 & 12.61 & in2 \\
\hline Volume - low & 22710 & liters & & liters & & & & \\
\hline Volume - high & 37850 & liters & & liters & & & & \\
\hline Coil - low & 2.18 & sq in / L & & sq in / L & & in2/L & 5.042544 & in $2 / \mathrm{L}$ \\
\hline Coil - high & 1.31 & sq in / L & & sq in / L & & watts & 1500 & watts \\
\hline & & & & & & watts & 350 & watts \\
\hline
\end{tabular}




\section{Appendix D - Nitrogen and Carbon Mass Balance Details}

Details of Nitrogen and Carbon Mass Balances are included in appendix D.

Table D1 Sludge Composition

\begin{tabular}{|l|c|c|c|c|l|l|l|l||}
\hline \hline Sludge & GN70 & GN76 & GN74 & GN79 & GN73 & GN75 & GN77 & GN78 \\
\hline Mass, g & $3,300.1$ & $19,130.0$ & $3,300.0$ & $146,551.0$ & $3,300.0$ & $3,300.0$ & $17,250.0$ & $124,839.0$ \\
\hline Sludge Sample Mass & 1.4421 & 3.224 & 1.05 & 102 & 3.904 & 2.1319 & 1.99 & 68.9 \\
\hline Density, g/mL & 1.14 & 1.14 & 1.14 & 1.14 & 1.14 & 1.14 & 1.14 & 1.14 \\
\hline Calcined Solids, wt \% & 12.69 & 12.69 & 12.69 & 12.69 & 12.69 & 12.69 & 12.69 & 12.69 \\
\hline Total Solids, wt \% & 17.5 & 17.5 & 17.5 & 17.5 & 17.5 & 17.5 & 17.5 & 17.5 \\
\hline Nitrate, mg/kg & 8,102 & 8,102 & 8,102 & 8,102 & 8,102 & 8,102 & 8,102 & 8,102 \\
\hline Nitrite, mg/kg & 12,365 & 12,365 & 12,365 & 12,365 & 12,365 & 12,365 & 12,365 & 12,365 \\
\hline Added Sodium Nitrite, g & 8.310 & 48.175 & 8.310 & 314.400 & 8.310 & 8.310 & 43.439 & 314.400 \\
\hline TIC, mg/kg & 1,437 & 1,437 & 1,437 & 1,437 & 1,437 & 1,437 & 1,437 & 1,437 \\
\hline Oxalate mg/kg & 2,013 & 2,013 & 2,013 & 2,013 & 2,013 & 2,013 & 2,013 & 2,013 \\
\hline Manganese, wt \% CS & 7.588 & 7.588 & 7.588 & 7.588 & 7.588 & 7.588 & 7.588 & 7.588 \\
\hline Mercury & 2.142 & 2.142 & 2.142 & 2.142 & 2.142 & 2.142 & 2.142 & 2.142 \\
\hline \hline
\end{tabular}

Table D2 SRAT Product Composition

\begin{tabular}{||l|c|c|c|c|c|c|c|c||}
\hline SRAT Product & GN70 & GN76 & GN74 & GN79 & GN73 & GN75 & GN77 & GN78 \\
\hline Mass, g & $2,815.3$ & $16,363.9$ & $2,826.6$ & $124,060.2$ & $2,862.7$ & $2,920.5$ & $15,182.2$ & $109,991.2$ \\
\hline SRAT Sample Mass, g & 579 & 3,742 & 557 & 11,484 & 557 & 555 & 2,890 & 10,856 \\
\hline Density, g/mL & 1.220 & 1.210 & 1.220 & 1.210 & 1.220 & 1.210 & 1.220 & 1.210 \\
\hline Nitrate, $\mathrm{mg} / \mathrm{kg}$ & 51,100 & 49,200 & 55,850 & 52,500 & 62,300 & 62,950 & 59,700 & 58,900 \\
\hline Nitrite, $\mathrm{mg} / \mathrm{kg}$ & 0 & 0 & 0 & 0 & 0 & 0 & 0 & 0 \\
\hline Glycolate $\mathrm{mg} / \mathrm{kg}$ & 51,500 & 50,500 & 46,200 & 48,050 & 51,000 & 51,300 & 49,100 & 49,600 \\
\hline Formate, $\mathrm{mg} / \mathrm{kg}$ & 849 & 1,050 & 571 & 313 & 444 & 456 & 474 & 161 \\
\hline Oxalate $\mathrm{mg} / \mathrm{kg}$ & 3,440 & 3,860 & 2,360 & 3,445 & 2,150 & 2,790 & 1,270 & 2,393 \\
\hline
\end{tabular}

Table D3 SME Product Composition

\begin{tabular}{||l|c|c|c|c|c|c|c|c||}
\hline SME Product & GN70 & GN76 & GN74 & GN79 & GN73 & GN75 & GN77 & GN78 \\
\hline Mass, g & 2,669 & 15,560 & 2,729 & 109,728 & 2,669 & 2,778 & 14,950 & 116,329 \\
\hline Density, $\mathrm{g} / \mathrm{mL}$ & 1.417 & 1.370 & 1.404 & 1.260 & 1.417 & 1.370 & 1.404 & 1.260 \\
\hline Nitrate, $\mathrm{mg} / \mathrm{kg}$ & 51,100 & 49,200 & 55,850 & 52,500 & 62,300 & 62,950 & 59,700 & 58,900 \\
\hline Nitrite, $\mathrm{mg} / \mathrm{kg}$ & 0 & 0 & 0 & 0 & 0 & 0 & 0 & 0 \\
\hline Glycolate $\mathrm{mg} / \mathrm{kg}$ & 51,200 & 46,800 & 46,200 & 48,050 & 47,900 & 51,300 & 47,100 & 49,600 \\
\hline Formate, $\mathrm{mg} / \mathrm{kg}$ & 918 & 1,640 & 440 & 313 & 347 & 305 & 258 & 108 \\
\hline Oxalate $\mathrm{mg} / \mathrm{kg}$ & 3,340 & 3,690 & 1,780 & 3,040 & 2,600 & 2,630 & 2,960 & 2,830 \\
\hline \hline
\end{tabular}


Table D4 Post SRAT Scrubber

\begin{tabular}{|l|c|c|c|c|c|c|c|c||}
\hline & GN70 & GN76 & GN74 & GN79 & GN73 & GN75 & GN77 & GN78 \\
\hline Mass, g & 751.10 & 751.00 & 751.00 & 2502.22 & 751.00 & 751.00 & 751.00 & 2245.00 \\
\hline Density, g/mL & 1.008 & 1.04 & 1.008 & 1.08 & 1.008 & 1.04 & 1.008 & 1.08 \\
\hline Nitrate, $\mathrm{mg} / \mathrm{L}$ & 18,400 & 97,800 & 18,200 & 192,000 & 14,500 & 12,700 & 62,600 & 139,000 \\
\hline Glycolate, mg/L & 0 & 0 & 0 & 0 & 0 & 0 & 0 & 0 \\
\hline Oxalate mg/L & 0 & 0 & 0 & 0 & 0 & 0 & 0 & 0 \\
\hline Formate, mg/L & 0 & 0 & 0 & 427 & 0 & 0 & 0 & 427 \\
\hline $\mathrm{NH}_{4}{ }^{+}, \mathrm{mg} / \mathrm{L}$ & 35 & & 10 & & 35 & & 10 & \\
\hline
\end{tabular}

Table D5 SRAT Dewater

\begin{tabular}{|l|c|c|c|c|c|c|c|c||}
\hline & GN70 & GN76 & GN74 & GN79 & GN73 & GN75 & GN77 & GN78 \\
\hline Mass, g & 1080 & 6261.9 & 1084.1 & 48154 & 1039.4 & 1039.5 & 5434.4 & 39069.3 \\
\hline Density, g/mL & 1.0040 & 1.0030 & 1.0035 & 1.0000 & 0.9884 & 1.0009 & 1.0027 & 1.003 \\
\hline Nitrate, $\mathrm{mg} / \mathrm{kg}$ & 10,000 & 8,680 & 9,150 & 5,210 & 6010 & 4880 & 8020 & 8800 \\
\hline Glycolate, $\mathrm{mg} / \mathrm{kg}$ & 45 & 83 & 17 & 36 & 31.9 & 37.1 & 34.9 & 54.5 \\
\hline Oxalate $\mathrm{mg} / \mathrm{kg}$ & $<100$ & $<100$ & $<100$ & $<100$ & $<100$ & $<100$ & $<100$ & $<100$ \\
\hline Formate, $\mathrm{mg} / \mathrm{L}$ & 128 & 127 & 46 & 109 & 150 & 135 & 91.5 & 148 \\
\hline
\end{tabular}

Table D6 MWWT Aqueous Composition

\begin{tabular}{|l|c|c|c|c|c|c|c|c||}
\hline & GN70 & GN76 & GN74 & GN79 & GN73 & GN75 & GN77 & GN78 \\
\hline Mass, g & 38.1132 & 241.627 & 35.201 & 1865.4 & 30.3309 & 36.6316 & 257.9 & 2177 \\
\hline Density, g/mL & 1 & 1 & 1 & 1 & 1 & 1 & 1 & 1 \\
\hline Nitrate, $\mathrm{mg} / \mathrm{kg}$ & $<100$ & $<100$ & 101 & $<100$ & $<100$ & $<100$ & $<100$ & $<100$ \\
\hline Glycolate, $\mathrm{mg} / \mathrm{kg}$ & $<100$ & $<100$ & $<100$ & $<100$ & $<100$ & $<100$ & $<100$ & $<100$ \\
\hline Oxalate $\mathrm{mg} / \mathrm{kg}$ & $<100$ & $<100$ & $<100$ & $<100$ & $<100$ & $<100$ & $<100$ & $<100$ \\
\hline Formate, $\mathrm{mg} / \mathrm{L}$ & $<100$ & $<100$ & $<100$ & $<100$ & $<100$ & $<100$ & $<100$ & $<100$ \\
\hline $\mathrm{NH}_{4}{ }^{+}, \mathrm{mg} / \mathrm{L}$ & & 6.9 & 9.1 & & $<5$ & $<5$ & 0.0 & 0.0 \\
\hline
\end{tabular}

Table D7 Post SRAT FAVC

\begin{tabular}{|l|c|c|c|c|c|c|c|c||}
\hline & GN70 & GN76 & GN74 & GN79 & GN73 & GN75 & GN77 & GN78 \\
\hline Mass, g & 15.5176 & 86.627 & 17.2011 & 731.8 & 14.5655 & 18.495 & 85.748 & 531.7 \\
\hline Density, g/mL & 1 & 1.053 & 1.100 & 1.025 & 1.075 & 1.075 & 1.046 & 1 \\
\hline Nitrate, $\mathrm{mg} / \mathrm{kg}$ & & 104,000 & 193,000 & 49,700 & 146,000 & 145,000 & 90,700 & 0 \\
\hline Glycolate, $\mathrm{mg} / \mathrm{kg}$ & 0 & $<100$ & $<100$ & $<100$ & $<100$ & $<100$ & $<100$ & 0 \\
\hline Oxalate $\mathrm{mg} / \mathrm{kg}$ & 0 & $<100$ & $<100$ & $<100$ & $<100$ & $<100$ & $<100$ & 0 \\
\hline Formate, $\mathrm{mg} / \mathrm{L}$ & 0 & $<100$ & $<100$ & $<100$ & $<100$ & $<100$ & 116 & 0 \\
\hline
\end{tabular}


SRNL-STI-2014-00306

Revision 0

Table D7 Post SME FAVC

\begin{tabular}{|l|c|c|c|c|c|c|c|c||}
\hline & GN70 & GN76 & GN74 & GN79 & GN73 & GN75 & GN77 & GN78 \\
\hline Mass, g & 10.5817 & 36.279 & 9.0631 & 261 & 6.834 & 10.0651 & 50.123 & 275.4 \\
\hline Density, g/mL & 1 & 1.000 & 1.010 & 1.019 & 1.006 & 1.005 & 1.000 & 1.135 \\
\hline Nitrate, $\mathrm{mg} / \mathrm{kg}$ & & 2,440 & 22,800 & 39,800 & 17,400 & 13,400 & 2,400 & 263,000 \\
\hline Glycolate, $\mathrm{mg} / \mathrm{kg}$ & 0 & $<100$ & $<100$ & $<100$ & $<100$ & $<100$ & $<100$ & $<100$ \\
\hline Oxalate $\mathrm{mg} / \mathrm{kg}$ & 0 & $<100$ & $<100$ & $<100$ & $<100$ & $<100$ & $<100$ & $<100$ \\
\hline Formate, $\mathrm{mg} / \mathrm{L}$ & 0 & $<100$ & $<100$ & 258 & $<100$ & $<100$ & $<100$ & 352 \\
\hline $\mathrm{NH}_{4}{ }^{+}, \mathrm{mg} / \mathrm{L}$ & & & & $<5$ & 0 & 0 & 0 & $<5$ \\
\hline
\end{tabular}

Table D8 SME Decon Dewater

\begin{tabular}{|l|l|l|l|l|l|l|l|l||}
\hline & \multicolumn{1}{|c|}{ GN70 } & \multicolumn{1}{|c|}{ GN76 } & \multicolumn{1}{|c|}{ GN74 } & \multicolumn{1}{|c|}{ GN79 } & GN73 & GN75 & GN77 & GN78 \\
\hline Mass, g & 3011.6 & 13437.4 & 2391.1 & 101178 & 2409.6 & 2409.6 & 12741.5 & 62718 \\
\hline Density, g/mL & 0.9982 & 0.9982 & 0.9979 & 0.9980 & 0.9982 & 0.9979 & 0.9982 & 0.998 \\
\hline Nitrate, $\mathrm{mg} / \mathrm{kg}$ & $<100$ & $<100$ & $<100$ & $<100$ & $<100$ & $<100$ & $<100$ & $<100$ \\
\hline Glycolate, $\mathrm{mg} / \mathrm{kg}$ & $<100$ & $<100$ & $<100$ & $<100$ & $<100$ & $<100$ & $<100$ & $<100$ \\
\hline Oxalate $\mathrm{mg} / \mathrm{kg}$ & $<100$ & $<100$ & $<100$ & $<100$ & $<100$ & $<100$ & $<100$ & $<100$ \\
\hline Formate, $\mathrm{mg} / \mathrm{L}$ & $<100$ & $<100$ & $<100$ & $<100$ & $<100$ & $<100$ & $<100$ & $<100$ \\
\hline
\end{tabular}

Table D9 SME Frit Dewater

\begin{tabular}{|l|c|c|c|c|c|c|c|c||}
\hline & GN70 & GN76 & GN74 & GN79 & GN73 & GN75 & GN77 & GN78 \\
\hline Mass, g & 745 & 4066.31 & 739.37 & 57895 & 785.4 & 781.1 & 4091.1 & 64527.8 \\
\hline Density, g/mL & 0.9982 & 0.9981 & 0.9927 & 0.9982 & 0.9979 & 0.9913 & 0.9966 & 0.9982 \\
\hline Nitrate, $\mathrm{mg} / \mathrm{kg}$ & $<100$ & $<100$ & $<100$ & $<100$ & $<100$ & $<100$ & $<100$ & $<100$ \\
\hline Glycolate, $\mathrm{mg} / \mathrm{kg}$ & $<100$ & $<100$ & $<100$ & $<100$ & $<100$ & $<100$ & $<100$ & $<100$ \\
\hline Oxalate $\mathrm{mg} / \mathrm{kg}$ & $<100$ & $<100$ & $<100$ & $<100$ & $<100$ & $<100$ & $<100$ & $<100$ \\
\hline Formate, $\mathrm{mg} / \mathrm{L}$ & $<100$ & $<100$ & $<100$ & $<100$ & $<100$ & $<100$ & $<100$ & $<100$ \\
\hline
\end{tabular}

Table D10 SRAT and SME Additions

\begin{tabular}{|l|c|c|c|c|c|c|c|c||}
\hline & GN70 & GN76 & GN74 & GN79 & GN73 & GN75 & GN77 & GN78 \\
\hline Nitric Acid Mass, g & 214.9 & 1246.1 & 234.4 & $10,329.3$ & 271.1 & 271.1 & 1416.9 & $9,985.9$ \\
\hline Nitric Acid Total Solids, wt \% & 48.59 & 48.59 & 48.59 & 48.96 & 48.59 & 48.59 & 48.59 & 48.96 \\
\hline Glycolic Acid Mass, g & 245.6 & $1,425.3$ & 230 & $10,210.1$ & 242.1 & 242 & $1,265.67$ & $9,158.8$ \\
\hline Glycolic Acid Total Solids, wt \% & 71.71 & 71.71 & 71.71 & 71.71 & 71.71 & 71.71 & 71.71 & 71.71 \\
\hline
\end{tabular}


SRNL-STI-2014-00306

Revision 0

Table D11 SRAT and SME Offgas Generation

\begin{tabular}{|c|c|c|c|c|c|c|c|c|}
\hline & GN70 & GN76 & GN74 & GN79 & GN73 & GN75 & GN77 & GN78 \\
\hline MS NO, mmol & 62.1 & & 42.0 & $2,385.0$ & 41.0 & 50.0 & 285.0 & $2,127.0$ \\
\hline FTIR NO, mmol & & 124.0 & & $2,650.0$ & 31.0 & 40.0 & 219.0 & $1,756.0$ \\
\hline $\mathrm{MS} \mathrm{NO}$, mmol & 116.3 & $1,537.0$ & 94.0 & $10,935.0$ & 60.0 & 64.0 & 726.0 & $6,073.0$ \\
\hline FTIR $\mathrm{NO}_{2}, \mathrm{mmol}$ & & $1,373.0$ & & $8,637.0$ & 52.0 & 55.0 & 610.0 & $4,880.0$ \\
\hline GC $\mathrm{N}_{2} \mathrm{O}, \mathrm{mmol}$ & 26.5 & 153.0 & 21.0 & $1,189.0$ & 9.0 & 21.0 & 135.0 & $1,087.0$ \\
\hline FTIR $\mathrm{N}_{2} \mathrm{O}, \mathrm{mmol}$ & & & & $1,024.0$ & 8.0 & 18.0 & 115.0 & 869.0 \\
\hline $\mathrm{MS} \mathrm{NH}, \mathrm{mmol}$ & & & & & 0.0 & 0.0 & 0.0 & 0.0 \\
\hline FTIR CO, mmol & & 11.2 & & 9.1 & 0.2 & 0.4 & 1.8 & 10.2 \\
\hline $\mathrm{GC} \mathrm{CO}_{2}, \mathrm{mmol}$ & $1,017.9$ & $6,767.0$ & 938.0 & $47,950.0$ & 964.0 & $1,017.0$ & $5,661.0$ & $40,503.0$ \\
\hline $\mathrm{MS} \mathrm{CO}_{2}, \mathrm{mmol}$ & $1,262.4$ & & 976.0 & $47,214.0$ & 899.0 & 930.0 & $5,331.0$ & $36,169.0$ \\
\hline FTIR $\mathrm{CO}_{2}, \mathrm{mmol}$ & & & & $47,863.0$ & 864.0 & 925.0 & $5,222.0$ & $36,170.0$ \\
\hline FTIR HDMSO, mmol & & 9.9 & & 64.9 & 0.8 & 0.6 & 8.0 & 74.4 \\
\hline
\end{tabular}


Table D12 SRAT and SME Nitrogen Calculations

\begin{tabular}{|c|c|c|c|c|c|c|c|c|}
\hline & GN70 & GN76 & GN74 & GN79 & GN73 & GN75 & GN77 & GN78 \\
\hline NITROGEN & GN70 & GN76 & GN74 & GN79 & $\mathrm{mol} \mathrm{N}$ & $\operatorname{mol~N}$ & $\operatorname{mol~N}$ & $\operatorname{mol~N}$ \\
\hline FEED: & $\mathrm{mol} \mathrm{N}$ & $\mathrm{mol} \mathrm{N}$ & $\mathrm{mol} \mathrm{N}$ & $\mathrm{mol} \mathrm{N}$ & 1.01 & 1.01 & 5.27 & 38.11 \\
\hline Sludge total $\mathrm{N}$ in nitrite & 1.01 & 5.84 & 1.01 & 43.95 & 0.43 & 0.43 & 2.25 & 16.31 \\
\hline Sludge Total N in nitrate & 0.43 & 2.50 & 0.43 & 19.15 & & & & \\
\hline ARP total $\mathrm{N}$ in nitrite & 0.00 & 0.00 & 0.00 & 0.00 & 0.00 & 0.00 & 0.00 & 0.00 \\
\hline ARP total $\mathrm{N}$ in nitrate & 0.00 & 0.00 & 0.00 & 0.00 & 0.00 & 0.00 & 0.00 & 0.00 \\
\hline Total $\mathrm{N}$ in Nitric Acid & 1.66 & 9.61 & 1.81 & 80.26 & 2.09 & 2.09 & 10.93 & 77.59 \\
\hline Total $\mathrm{N}$ in Feed & 3.096 & 17.948 & 3.246 & 143.352 & 3.529 & 3.529 & 18.446 & 132.011 \\
\hline Corrected N for Samples & 3.094 & 17.945 & 3.245 & 143.253 & 3.525 & 3.527 & 18.444 & 131.939 \\
\hline SRAT CYCLE PRODUCTS: & $\mathrm{mol} \mathrm{N}$ & $\mathrm{mol} \mathrm{N}$ & $\mathrm{mol} \mathrm{N}$ & $\mathrm{mol} \mathrm{N}$ & $\mathrm{mol} \mathrm{N}$ & $\mathrm{mol} \mathrm{N}$ & $\mathrm{mol} \mathrm{N}$ & mol N \\
\hline SRAT Product nitrate as $\mathrm{N}$ & 2.32 & 12.98 & 2.55 & 105.04 & 2.88 & 2.97 & 14.62 & 104.48 \\
\hline $\begin{array}{l}\text { NOx measured } \\
\left(\mathrm{NO}+\mathrm{NO}_{2}+2 * \mathrm{~N}_{2} \mathrm{O}\right)\end{array}$ & 0.231 & 1.967 & 0.178 & 15.963 & 0.119 & 0.156 & 1.281 & 10.374 \\
\hline Scrubber nitrate as $\mathrm{N}$ & 0.22 & 1.18 & 0.22 & 7.75 & 0.18 & 0.15 & 0.76 & 5.03 \\
\hline Dewater nitrate as $\mathrm{N}$ & 0.17 & 1.02 & 0.22 & 4.80 & 0.14 & 0.13 & 0.83 & 6.71 \\
\hline MWWT nitrate as $\mathrm{N}$ & 0.00 & 0.00 & 0.00 & 0.00 & 0.00 & 0.00 & 0.00 & 0.00 \\
\hline Total condensate $\mathrm{N}$ & 0.40 & 2.21 & 0.44 & 12.55 & 0.31 & 0.28 & 1.59 & 11.75 \\
\hline Total $\mathrm{N}$ in $\mathrm{NH}_{3}$, mol & 0.001 & 0.000 & 0.000 & 0.000 & 0.001 & 0.000 & 0.000 & 0.000 \\
\hline total nitrite to offgas, mol & 0.63 & 4.17 & 0.62 & 28.51 & 0.43 & 0.44 & 2.87 & 22.12 \\
\hline TOTAL N IN PRODUCTS & 2.95 & 17.16 & 3.16 & 133.55 & 3.31 & 3.40 & 17.49 & 126.60 \\
\hline N Delta & 0.14 & 0.79 & 0.08 & 9.70 & 0.22 & 0.12 & 0.96 & 5.34 \\
\hline \% Closure & $95.3 \%$ & $95.6 \%$ & $97.4 \%$ & $93.2 \%$ & $93.9 \%$ & $96.5 \%$ & $94.8 \%$ & $96.0 \%$ \\
\hline \multicolumn{9}{|l|}{ N Destruction Calcs, \%: } \\
\hline nitrite to nitrate by diff, mol & 0.38 & 1.66 & 0.39 & 15.43 & 0.57 & 0.57 & 2.40 & 15.99 \\
\hline$\%$ of nitrite to offgas & $23.0 \%$ & $33.7 \%$ & $17.7 \%$ & $36.3 \%$ & $11.8 \%$ & $15.5 \%$ & $24.3 \%$ & $27.2 \%$ \\
\hline$\%$ nitrite to condensate & $39.4 \%$ & $37.8 \%$ & $43.4 \%$ & $28.6 \%$ & $31.0 \%$ & $27.9 \%$ & $30.2 \%$ & $30.8 \%$ \\
\hline$\%$ nitrite to SRAT nitrate & $37.6 \%$ & $28.5 \%$ & $38.9 \%$ & $35.1 \%$ & $57.2 \%$ & $56.6 \%$ & $45.5 \%$ & $42.0 \%$ \\
\hline \multicolumn{9}{|c|}{ Acid Calc \% nitrite to SRAT nitrate } \\
\hline nitrite to nitrate by diff, mol & $37.5 \%$ & $28.5 \%$ & $38.9 \%$ & $35.1 \%$ & $57.0 \%$ & $56.6 \%$ & $45.5 \%$ & $42.0 \%$ \\
\hline $\begin{array}{l}\text { init nitrate }+\mathrm{HNO}_{3}+(\text { nitrite to } \\
\text { nitrate)-final nitrate-nitrate in } \\
\text { samples }\end{array}$ & 1.15 & 6.63 & 1.09 & 53.64 & 1.22 & 1.13 & 6.22 & 43.45 \\
\hline $\mathrm{NO}, \mathrm{mmol}$ & 62.1 & 124.0 & 42.0 & $2,650.0$ & 31.0 & 40.0 & 219.0 & $1,756.0$ \\
\hline $\mathrm{NO}_{2}, \mathrm{mmol}$ & 116.3 & $1,537.0$ & 94.0 & $10,935.0$ & 60.0 & 64.0 & 726.0 & $6,073.0$ \\
\hline $\mathrm{GC} \mathrm{N}_{2} \mathrm{O}, \mathrm{mmol}$ & 26.5 & 153.0 & 21.0 & $1,189.0$ & 9.0 & 21.0 & 135.0 & $1,087.0$ \\
\hline Total N mmol & 231.4 & $1,967.0$ & 178.0 & $15,963.0$ & 109.0 & 146.0 & $1,215.0$ & $10,003.0$ \\
\hline $\mathrm{NO}$ & $0.0 \%$ & $6.3 \%$ & $0.0 \%$ & $16.6 \%$ & $28.4 \%$ & $27.4 \%$ & $18.0 \%$ & $17.6 \%$ \\
\hline
\end{tabular}


SRNL-STI-2014-00306

Revision 0

Table D12 SRAT and SME Nitrogen Calculations

\begin{tabular}{|c|c|c|c|c|c|c|c|c|}
\hline & GN70 & GN76 & GN74 & GN79 & GN73 & GN75 & GN77 & GN78 \\
\hline $\mathrm{NO}_{2}$ & $50.3 \%$ & $78.1 \%$ & $52.8 \%$ & $68.5 \%$ & $55.0 \%$ & $43.8 \%$ & $59.8 \%$ & $60.7 \%$ \\
\hline $\mathrm{GC} \mathrm{N}_{2} \mathrm{O}$ & $11.5 \%$ & $7.8 \%$ & $11.8 \%$ & $7.4 \%$ & $8.3 \%$ & $14.4 \%$ & $11.1 \%$ & $10.9 \%$ \\
\hline \multicolumn{9}{|l|}{ Total Nitrate } \\
\hline $\mathrm{NO} / \mathrm{NO}_{\mathrm{x}}$ ratio & 0.268 & 0.063 & 0.236 & 0.166 & 0.284 & 0.274 & 0.180 & 0.176 \\
\hline Nitrogen overall balance & $95.3 \%$ & $95.6 \%$ & $97.4 \%$ & $93.2 \%$ & $93.9 \%$ & $96.5 \%$ & $94.8 \%$ & $96.0 \%$ \\
\hline Nitrate $\%$ of $\mathrm{N}$ balance & $93.0 \%$ & $89.4 \%$ & $95.0 \%$ & $88.9 \%$ & $96.9 \%$ & $96.3 \%$ & $93.8 \%$ & $93.0 \%$ \\
\hline NO \% of $\mathrm{N}$ balance & $2.1 \%$ & $0.7 \%$ & $1.3 \%$ & $2.0 \%$ & $0.9 \%$ & $1.2 \%$ & $1.3 \%$ & $1.4 \%$ \\
\hline $\mathrm{NO}_{2} \%$ of $\mathrm{N}$ balance & $3.9 \%$ & $9.0 \%$ & $3.0 \%$ & $8.2 \%$ & $1.8 \%$ & $1.9 \%$ & $4.2 \%$ & $4.8 \%$ \\
\hline $\mathrm{N}_{2} \mathrm{O} \%$ of $\mathrm{N}$ balance & $0.9 \%$ & $0.9 \%$ & $0.7 \%$ & $0.9 \%$ & $0.3 \%$ & $0.6 \%$ & $0.8 \%$ & $0.9 \%$ \\
\hline $\mathrm{NH}_{3} \%$ of nitrogen balance & $0.0 \%$ & $0.0 \%$ & $0.0 \%$ & $0.0 \%$ & $0.0 \%$ & $0.0 \%$ & $0.0 \%$ & $0.0 \%$ \\
\hline SRAT \% Nitrite Destruction & $100 \%$ & $100 \%$ & $100 \%$ & $100 \%$ & $100 \%$ & $100 \%$ & $100 \%$ & $100 \%$ \\
\hline $\begin{array}{lrlr}\text { SRAT \% Nitrite } & \text { to } & \text { Nitrate } \\
\text { Conversion } & & & \\
\end{array}$ & $37.6 \%$ & $28.5 \%$ & $38.9 \%$ & $35.1 \%$ & $57.2 \%$ & $56.6 \%$ & $45.5 \%$ & $42.0 \%$ \\
\hline SME Nitrate Destruction & $19.3 \%$ & $23.3 \%$ & $20.3 \%$ & $-2.5 \%$ & $15.8 \%$ & $17.4 \%$ & $21.6 \%$ & $17.3 \%$ \\
\hline
\end{tabular}

\section{Table D13 SRAT and SME Carbon Calculations}

\begin{tabular}{|c|c|c|c|c|c|c|c|c||}
\hline CARBON & GN70 & GN76 & GN74 & GN79 & GN73 & GN75 & GN77 & GN78 \\
\hline FEED: & mol C & mol C & mol C & mol C & mol C & mol C & mol C & mol C \\
\hline Sludge CO3 as C & 0.395 & 2.289 & 0.395 & 17.534 & 0.395 & 0.395 & 2.064 & 14.936 \\
\hline ARP CO3 as C & 0.000 & 0.000 & 0.000 & 0.000 & 0.000 & 0.000 & 0.000 & 0.000 \\
\hline Sludge oxalate as C & 0.151 & 0.875 & 0.151 & 6.703 & 0.151 & 0.151 & 0.789 & 5.710 \\
\hline ARP oxalate as C & 0.000 & 0.000 & 0.000 & 0.000 & 0.000 & 0.000 & 0.000 & 0.000 \\
\hline Glycolic acid added & 4.632 & 26.879 & 4.337 & 192.545 & 4.566 & 4.564 & 23.868 & 172.719 \\
\hline Total C in Feed & 5.177 & 30.043 & 4.883 & 216.782 & 5.111 & 5.109 & 26.721 & 193.366 \\
\hline Corrected C & 5.175 & 30.037 & 4.882 & 216.632 & 5.105 & 5.106 & 26.718 & 193.259 \\
\hline SRAT CYCLE PRODUCTS: & & & & & & & & \\
\hline SRAT Product Glycolate as C & 3.864 & 22.024 & 3.480 & 158.871 & 3.891 & 3.993 & 19.867 & 145.398 \\
\hline SRAT Product Formate as C & 0.053 & 0.382 & 0.036 & 0.863 & 0.028 & 0.030 & 0.160 & 0.393 \\
\hline SRAT Product Oxalate as C & 0.220 & 1.435 & 0.152 & 9.711 & 0.140 & 0.185 & 0.438 & 5.981 \\
\hline SRAT Product Carbonate as C & 0.000 & 0.000 & 0.000 & 0.000 & 0.000 & 0.000 & 0.000 & 0.000 \\
\hline CO and CO in offgas $_{\text {Scrubber C }}^{1.018}$ & 6.778 & 0.938 & 47.959 & 0.964 & 1.017 & 5.663 & 40.513 \\
\hline Dewater C & 0.00 & 0.00 & 0.00 & 0.02 & 0.00 & 0.00 & 0.00 & 0.02 \\
\hline MWWT C & 0.00 & 0.03 & 0.00 & 0.16 & 0.00 & 0.00 & 0.02 & 0.19 \\
\hline Total condensate C & 0.00 & 0.00 & 0.00 & 0.00 & 0.00 & 0.00 & 0.00 & 0.00 \\
\hline
\end{tabular}




\begin{tabular}{|c|c|c|c|c|c|c|c|c|}
\hline \multicolumn{9}{|c|}{ Table D13 SRAT and SME Carbon Calculations } \\
\hline CARBON & GN70 & GN76 & GN74 & GN79 & GN73 & GN75 & GN77 & GN78 \\
\hline Total C in Products & 5.160 & 30.651 & 4.607 & 217.592 & 5.028 & 5.229 & 26.144 & 192.493 \\
\hline C Delta & 0.016 & -0.613 & 0.274 & -0.960 & 0.078 & -0.123 & 0.574 & 0.766 \\
\hline \multirow[t]{2}{*}{$\%$ Closure } & $99.7 \%$ & $102.0 \%$ & $94.4 \%$ & $100.4 \%$ & $98.5 \%$ & $102.4 \%$ & $97.9 \%$ & $99.6 \%$ \\
\hline & 0.000000 & 0.000000 & 0.000000 & 0.000000 & & & & \\
\hline \multicolumn{9}{|l|}{ C Destruction Calcs, mol } \\
\hline Glycolate destruction & 0.77 & 4.85 & 0.86 & 33.54 & 0.67 & 0.57 & 4.00 & 27.23 \\
\hline $\mathrm{CO}_{2}$ from Glycolate destruction & 0.00 & 0.00 & 0.00 & 0.00 & 0.00 & 0.00 & 0.00 & 0.00 \\
\hline $\mathrm{CO}_{2}$ from $\mathrm{CO}_{3}$ & 0.39 & 2.29 & 0.39 & 17.53 & 0.39 & 0.39 & 2.06 & 14.94 \\
\hline Total $\mathrm{CO}_{2}$ generated & 0.39 & 2.29 & 0.39 & 17.53 & 0.39 & 0.39 & 2.06 & 14.94 \\
\hline $\mathrm{CO}+\mathrm{CO}_{2}$ measured & 1.02 & 6.78 & 0.94 & 47.96 & 0.96 & 1.02 & 5.66 & 40.51 \\
\hline HMDSO & 0.000 & 0.00986 & 0.000 & 0.06494 & 0.00078 & 0.00063 & 0.008040 & 0.074370 \\
\hline \multicolumn{9}{|l|}{ C Destruction Calcs, \%: } \\
\hline Carbon overall balance & $99.7 \%$ & $102.0 \%$ & $94.4 \%$ & $100.4 \%$ & $98.5 \%$ & $102 \%$ & $97.9 \%$ & $99.6 \%$ \\
\hline Glycolate \% of C balance & $74.9 \%$ & $71.9 \%$ & $75.5 \%$ & $73.0 \%$ & $77.4 \%$ & $76.4 \%$ & $76.0 \%$ & $75.5 \%$ \\
\hline Oxalate \% of C balance & $4.3 \%$ & $4.7 \%$ & $3.3 \%$ & $4.5 \%$ & $2.8 \%$ & $3.5 \%$ & $1.7 \%$ & $3.1 \%$ \\
\hline Formate \% of C balance & $1.0 \%$ & $1.2 \%$ & $0.8 \%$ & $0.4 \%$ & $0.6 \%$ & $0.6 \%$ & $0.6 \%$ & $0.2 \%$ \\
\hline $\mathrm{CO}_{2} \%$ of $\mathrm{C}$ balance & $19.7 \%$ & $22.1 \%$ & $20.4 \%$ & $22.0 \%$ & $19.2 \%$ & $19.4 \%$ & $21.7 \%$ & $21.0 \%$ \\
\hline $\mathrm{CO} \%$ of $\mathrm{C}$ balance & $0.0 \%$ & $0.0 \%$ & $0.0 \%$ & $0.0 \%$ & $0.0 \%$ & $0.0 \%$ & $0.0 \%$ & $0.0 \%$ \\
\hline Antifoam C \% of C balance & $0.0 \%$ & $0.0 \%$ & $0.0 \%$ & $0.0 \%$ & $0.0 \%$ & $0.0 \%$ & $0.0 \%$ & $0.0 \%$ \\
\hline SRAT \% glycolate Destruction & $16.6 \%$ & $18.1 \%$ & $19.8 \%$ & $17.5 \%$ & $14.8 \%$ & $12.5 \%$ & $16.8 \%$ & $15.8 \%$ \\
\hline SRAT \% oxalate Generation & $45.8 \%$ & $64.0 \%$ & $0.4 \%$ & $44.9 \%$ & $-7.3 \%$ & $22.7 \%$ & $-44.5 \%$ & $4.7 \%$ \\
\hline SRAT \% formate Generation & NA & NA & NA & NA & NA & NA & NA & NA \\
\hline SME \% glycolate Destruction & $18.6 \%$ & $14.3 \%$ & $20.3 \%$ & $-2.5 \%$ & $8.7 \%$ & $17.4 \%$ & $16.7 \%$ & $17.3 \%$ \\
\hline SME \% oxalate Generation & $15.9 \%$ & $17.9 \%$ & $-9.3 \%$ & $-14.0 \%$ & $40.0 \%$ & $10.7 \%$ & $183.5 \%$ & $38.8 \%$ \\
\hline SME \% formate Generation & $29.0 \%$ & $92.6 \%$ & $-7.3 \%$ & $-2.5 \%$ & $-9.5 \%$ & $-21.5 \%$ & $-33.8 \%$ & $-21.3 \%$ \\
\hline \multicolumn{9}{|l|}{ Carbonate/ $\mathrm{CO}_{2}$ Balance } \\
\hline Carbonate in Sludge & 0.395 & 2.289 & 0.395 & 17.534 & 0.395 & 0.395 & 2.064 & 14.936 \\
\hline $\mathrm{CO}_{2}$ generation & 1.018 & 6.778 & 0.938 & 47.959 & 0.964 & 1.017 & 5.663 & 40.513 \\
\hline $\mathrm{CO}_{2}$ from other reactions & 0.623 & 4.489 & 0.543 & 30.425 & 0.569 & 0.623 & 3.599 & 25.577 \\
\hline Reduction of Mn & 0.385 & 2.235 & 0.385 & 17.112 & 0.385 & 0.385 & 2.015 & 14.579 \\
\hline Reduction of $\mathrm{Hg}$ & 0.041 & 0.238 & 0.041 & 1.824 & 0.041 & 0.041 & 0.215 & 1.554 \\
\hline Other $\mathrm{CO}_{2}$ Generation & 0.197 & 2.016 & 0.117 & 11.488 & 0.143 & 0.196 & 1.369 & 9.443 \\
\hline$\%$ unidentified $\mathrm{CO}_{2}$ & $19.3 \%$ & $29.7 \%$ & $12.4 \%$ & $24.0 \%$ & $14.9 \%$ & $19.3 \%$ & $24.2 \%$ & $23.3 \%$ \\
\hline
\end{tabular}




\section{Appendix E - GC SRAT and SME Cycle Offgas Plots}

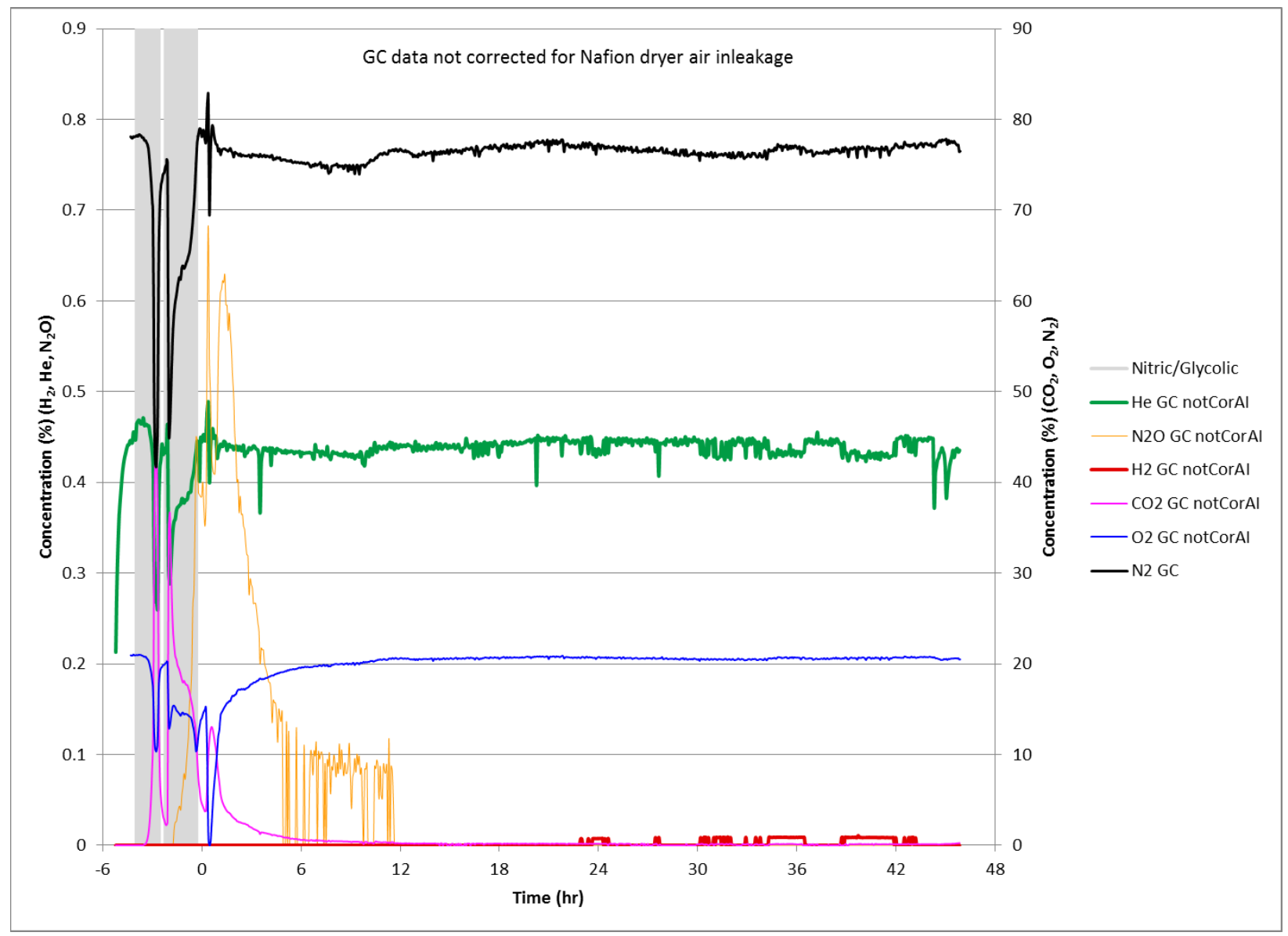

Figure E-1: GN $70 \mathrm{He}, \mathrm{N}_{2} \mathrm{O}, \mathrm{H}_{2}, \mathrm{CO}_{2}, \mathrm{O}_{2}$ and $\mathrm{N}_{2}$ Concentration, volume \% 
SRNL-STI-2014-00306

Revision 0

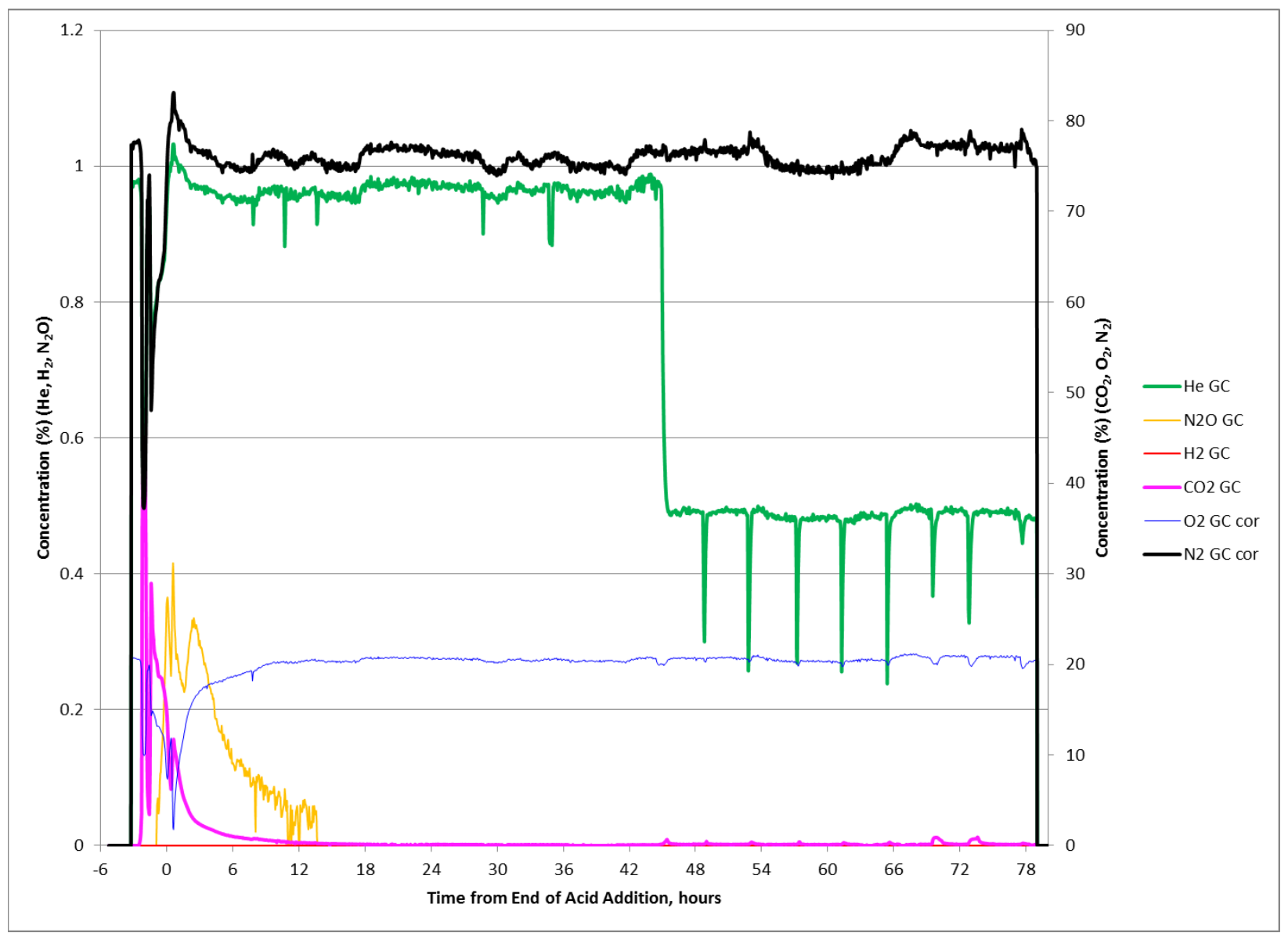

Figure E-2: GN $74 \mathrm{He}, \mathrm{N}_{2} \mathrm{O}, \mathrm{H}_{2}, \mathrm{CO}_{2}, \mathrm{O}_{2}$ and $\mathrm{N}_{2}$ Concentration, volume \% 
SRNL-STI-2014-00306

Revision 0

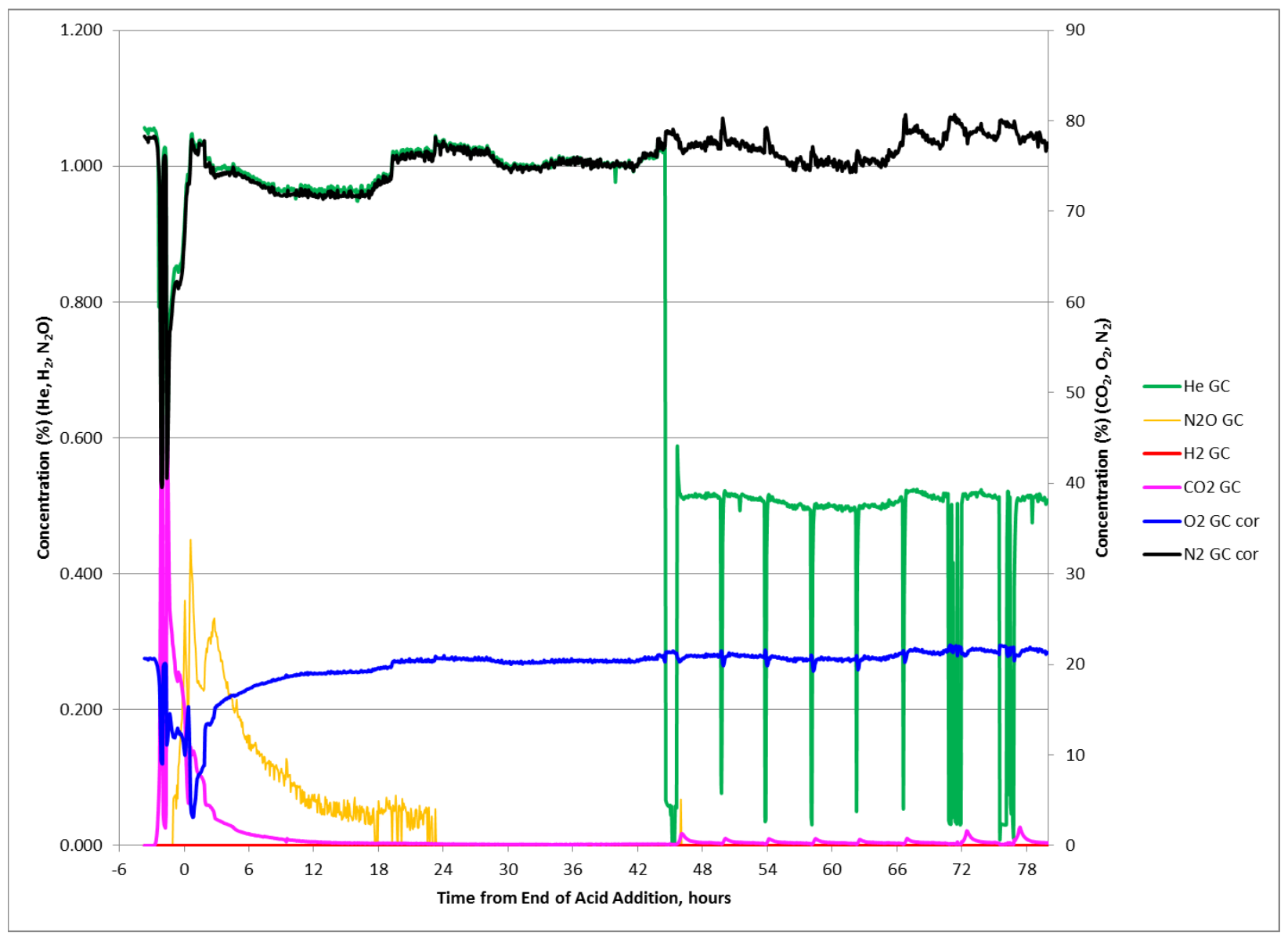

Figure E-3: GN $76 \mathrm{He}, \mathrm{N}_{2} \mathrm{O}, \mathrm{H}_{2}, \mathrm{CO}_{2}, \mathrm{O}_{2}$ and $\mathrm{N}_{2}$ Concentration, volume \% 


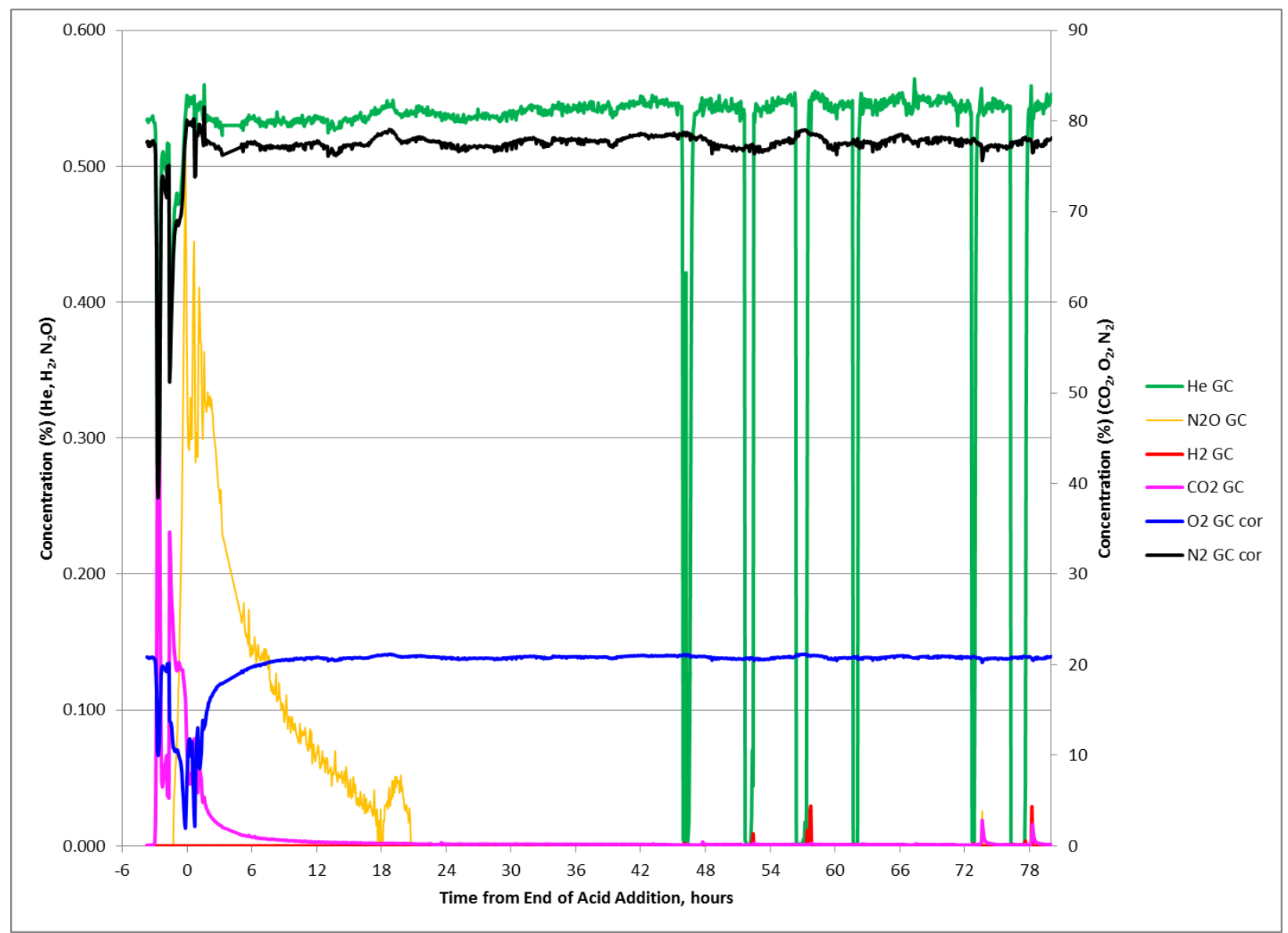

Figure E-4: GN $79 \mathrm{He}, \mathrm{N}_{2} \mathrm{O}, \mathrm{H}_{2}, \mathrm{CO}_{2}, \mathrm{O}_{2}$ and $\mathrm{N}_{2}$ Concentration, volume \% 
SRNL-STI-2014-00306

Revision 0

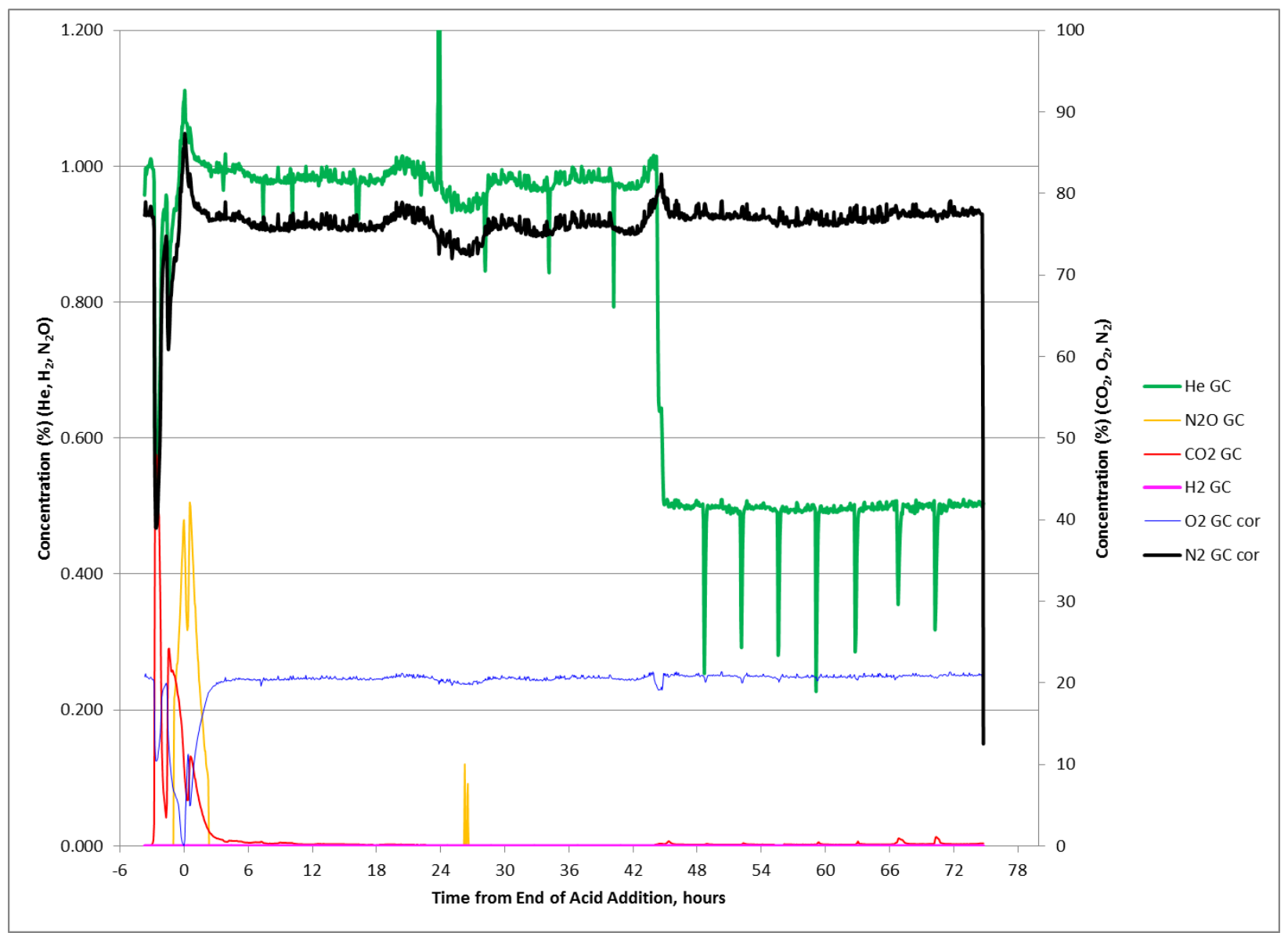

Figure E-5: GN $73 \mathrm{He}, \mathrm{N}_{2} \mathrm{O}, \mathrm{H}_{2}, \mathrm{CO}_{2}, \mathrm{O}_{2}$ and $\mathrm{N}_{2}$ Concentration, volume \% 
SRNL-STI-2014-00306

Revision 0

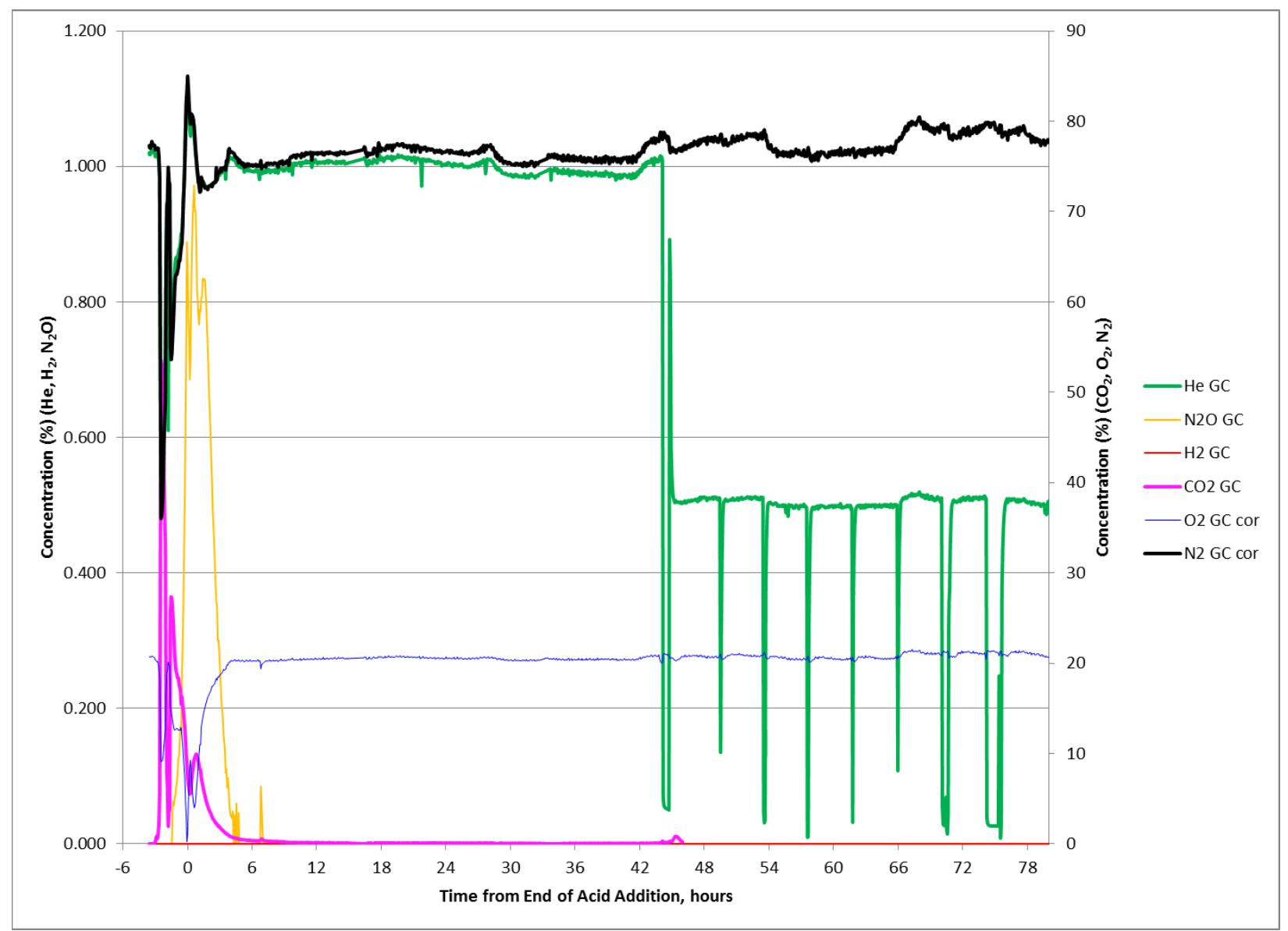

Figure E-6: GN $77 \mathrm{He}, \mathrm{N}_{2} \mathrm{O}, \mathrm{H}_{2}, \mathrm{CO}_{2}, \mathrm{O}_{2}$ and $\mathrm{N}_{2}$ Concentration, volume \% 
SRNL-STI-2014-00306

Revision 0

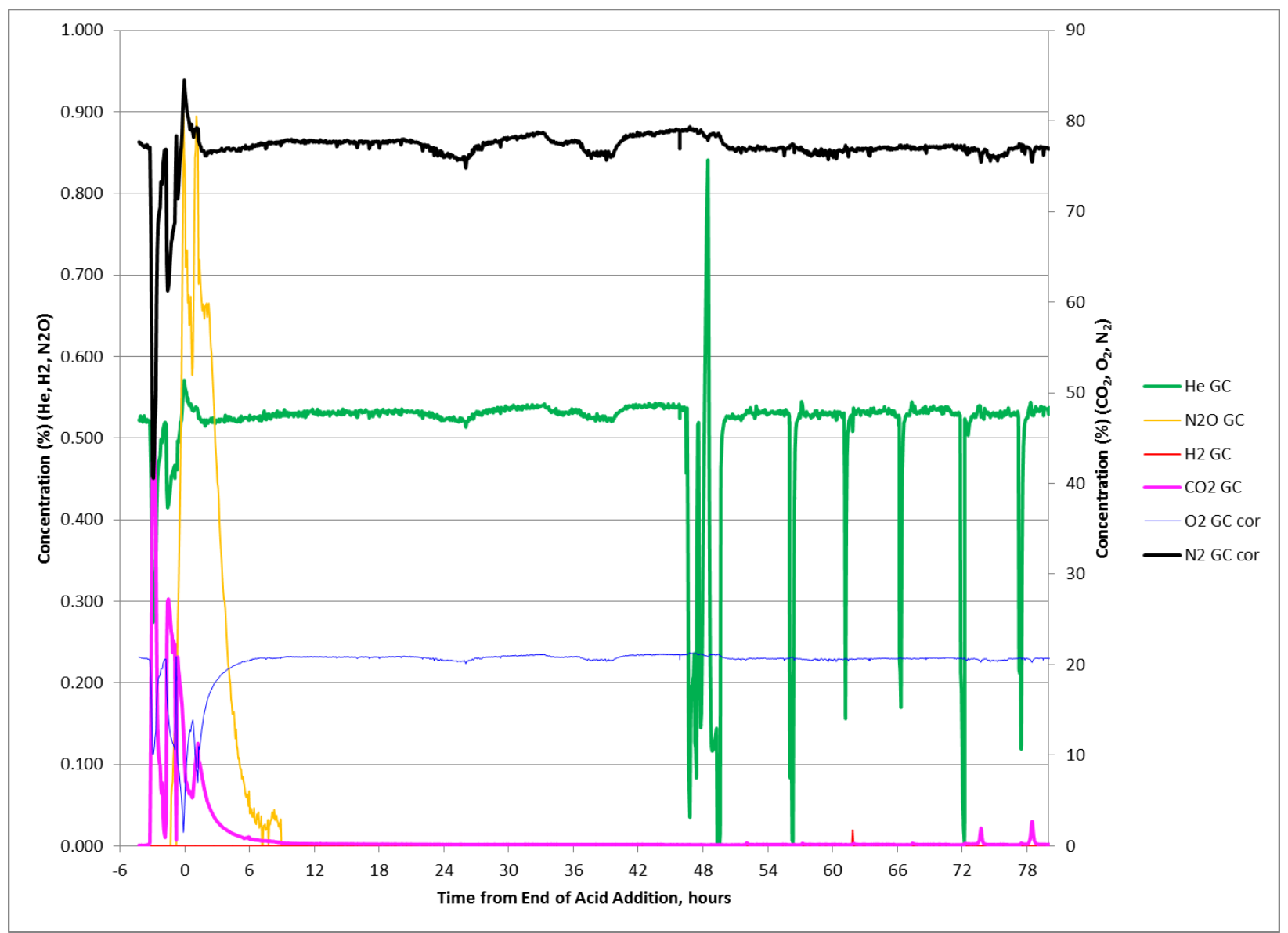

Figure E-7: GN $78 \mathrm{He}, \mathrm{N}_{2} \mathrm{O}, \mathrm{H}_{2}, \mathrm{CO}_{2}, \mathrm{O}_{2}$ and $\mathrm{N}_{2}$ Concentration, volume \% 


\section{Distribution:}

D.E. Dooley, 999-W

A. P. Fellinger. 773-42A

T. B. Brown, 773-A

D. H. McGuire, 999-W

S. D. Fink, 773-A

C. C. Herman, 773-A

E. N. Hoffman, 999-W

F. M. Pennebaker, 773-42A

W. R. Wilmarth, 773-A

Records Administration (EDWS)

H.P. Boyd, 704-27S

J. M. Bricker, 704-S

R. Cantrell, 705-1C

T.E. Colleran, 773-67A

J. S. Contardi, 704-56H

Richard Edwards, 766-H

T. L. Fellinger, 766-H

E. J. Freed, 704-S

J. M. Gillam, 766-H

B. A. Hamm, 766-H

E. W. Holtzscheiter, 766-H

J. F. Iaukea, 704-27S

S.T. Isom, 773-67A

V. Jain, 766-H

L.C. Jamison, 707-3E

R.T. McNew, 766-H

S.G. Phillips, 773-67A

W.O. Pepper 704-71S

J. W. Ray, 704-27S

P. J. Ryan, 704-26S

M. A. Rios-Armstrong, 766-H

A. Samadi, 704-27S

H. B. Shah, 766-H

D. C. Sherburne, 249-8H

M. E. Stone, 999-W

C. Sudduth, 707-7E

P.N. Hang, 704-S

T.C. Temple, 704-S

R.E. Gonzalez, 704-S

P. R. Jackson, DOE-SR, 703-46A

J. A. Crenshaw, 703-46A

S. T. Isom, 773-67A 